\title{
A CIDADE DOS “AFOGADOS”: A MEMÓRIA, A HISTÓRIA E A LUTA PELO DIREITO À CIDADE DE NOVA PONTE
}

\author{
Dissertação apresentada à Escola de Engenharia \\ de São Carlos da Universidade de São Paulo \\ como parte dos requisitos para a obtenção do \\ Título de Mestre em Teoria e História da \\ Arquitetura e do Urbanismo
}

ORIENTADORA: Profa. Dra. Cibele Saliba Rizek

São Carlos

2005 
Dedico este trabalho ao meu filho Victor Hugo, minha inseparável companhia, minha motivação e incentivo, minha luz, minha vida. 


\section{AGRADECIMENTOS}

À Profa. Dra. Cibele Saliba Rizek pela oportunidade de desenvolver esta dissertação, pela orientação durante o percurso da pesquisa, pela convivência enriquecedora e pela amizade.

Aos meus amigos Anna Rachel, Claudius, Bianca, Paulinho, Lúcia, Gabriel, Daniele e Marcelinho, pelo tempo que estivemos juntos, pela partilha de experiências, pela convivência inesquecível.

Aos Profs. Drs. Carlos Roberto Monteiro de Andrade, José Tavares Correia de Lira, Telma de Barros Correia, Nabil Georges Bonduki, Hugo Segawa, Fábio Lopes de Souza Santos, Mário Henrique Simão D’Agostino, pelo excelente suporte e amizade.

Ao meu companheiro e amigo, Vitor Hugo pela presteza e ajuda com nosso filho em muitas madrugadas durante 0 desenvolvimento deste trabalho, pela companhia nas inúmeras viagens, pela paciência e o amor.

À minha mãe Lourdinha, minha maior incentivadora e companheira, pelo apoio incondicional; às minhas irmãs Virgínia e Daniela pelas noites de leitura e crítica do texto; ao Crema, meu pai, pelas noites de preocupação com as minhas viagens; e ao meu irmão Gustavo pelo incentivo.

À Engenheira do IBAMA e MMA, Lúcia Regina Moreira Oliveira pela colaboração com a pesquisa, pela atenção, carinho e amizade; à Profa. Juliana Oliveira de Senne, pela leitura dos textos em inglês, paciência e amizade.

Aos entrevistados que gentilmente abriram suas residências e suas vidas para colaborarem com esta pesquisa, pela simpatia e paciência.

A Universidade de São Paulo por disponibilizar sua estrutura para o desenvolvimento desta pesquisa; à CAPES pelo fomento de parte desta pesquisa. Aos funcionários da biblioteca e da graduação e pós-graduação do Departamento de Arquitetura da Escola de Engenharia de São Carlos. 


\section{RESUMO}

CREMA, A.O. A cidade dos "afogados": a memória, a história e a luta pelo direito à cidade de Nova Ponte. 2005. Dissertação (Mestrado) - Escola de Engenharia de São Carlos, Universidade de São Paulo, São Carlos, 2005.

A cidade de Nova Ponte, no Triângulo Mineiro, teve sua área urbana totalmente inundada pelas águas da Usina Hidrelétrica de Nova Ponte, e sua população reassentada em uma nova cidade construída a três quilômetros da antiga. $O$ trabalho busca levantar as questões sociais, econômicas, políticas e culturais, no processo dessa transferência e de sua transformação urbana. Diagnosticar os caminhos percorridos por esta sociedade, através do levantamento de questões de apropriação do espaço, a relação entre as esferas públicas e privadas, dando significado à memória em espaços cotidianos distintos, mas correlacionados. Questiona sobre o fazer arquitetônico e a história, a relação entre a idéia de sujeito e lugar, no momento em que os projetos hidrelétricos seriam o suporte para novas experimentações arquitetônicas, a partir de uma velha cidade condicionada à esfera doméstica e dominada pelas relações de produção pré-capitalistas. Considerando a relação entre o investimento de capital no processo de construção do urbano, a intervenção do Estado, aliado a setores de capital, e a organização das forças sociais em Nova Ponte, através da fundação de sindicatos e movimentos populares na luta pela nova cidade.

Palavras - chave: cidades novas; o direito à cidade; urbano e história. 


\section{ABSTRACT}

CREMA, A.O. The town of "drowned": the memory, the history and fight for rights for Nova Ponte town. 2005. M.Sc. Dissertation - Escola de Engenharia de São Carlos, Universidade de São Paulo, São Carlos, 2005.

The recent Brazilian history has revealed the conflict between development interest such as the barrage construction and the population settled in areas designated to be flooded. However, it has shown a progress in the way of dealing, which allows an interaction of the parts aiming their social realities. The electrical sector traditional practice used to expropriate with as indemnity payment, being diagnosed potentials impacts that could cause family disturbance, loss of identity, social exclusion, and so on. The case study of Nova Ponte town, located in Triângulo Mineiro, which had its whole urban area submerged by the barrage water in order to construct the hydro electrical power plant of Nova Ponte and the arise of a new town, discuss how this change questions the community cultural identity, since this population wish they would keep the relationships and the customary habits like in the old town.

Keywords: new town; fight for rights for town; urban and history. 


\section{ÍNDICE DE IMÁGENS}

Figura. 01 - Os bairros de Nova Ponte 25

Figura. 02 - Praça São Miguel 26

$\begin{array}{ll}\text { Figura. } 03 \text { - A praça São Miguel, seus bancos e esquinas } 27 & 27\end{array}$

Figura. 04 - Loja Móveis Pena $\quad 29$

Figura. 05 - Farmácia Droganova 30

Figura. 06 - Bar do Bitinha 30

Figura. 08 - Os banquinhos 32

Figura. 07 - Referências dos Bairros São Miguel e Rosário 33

Figura. 09 - Referências do Bairro São Francisco 35

Figura. 10 - Sede Social da Associação Atlética Novapontesse 36

Figura. 11 - O rural e o urbano em Nova Ponte 36

Figura. 12 - Praça e Igreja de São Sebastião na velha cidade 38

Figura. 13 - Referências do Bairro São Sebastião 39

Figura. 14 - Capela de São João $\quad 41$

Figura. 15 - Referências do Bairro São João 42

Figura. 16 - Década de 50 - senhoras roupa no rio 48

Figura. 17 - A ponte sobre o rio Araguari 48

Figura. 18 - A rua que ligava os Bairros da velha cidade 48

Figura. 19 - O Carnaval na praia artificial da nova cidade 53

Figura. 20 - Imagem da ponte, do rio e da Cavalhada na velha cidade $\quad 54$

Figura. 21 - A Cavalhada na cidade nova $\quad 54$ 
Figura. 22 - Fachada do Chalezinho na velha cidade

Figura. 23 - Fachada do chalezinho

Figura. 24 - Elevações do Chalezinho 57

Figura. 25 - Planta baixa do Chalezinho 58

Figura 26 - Detalhamentos do Chalezinho 58

Figura. 27 - Detalhe de vedação do Chalezinho 58

Figura. 28 - Fachada da Fazenda Cachoeira $\quad 59$

$\begin{array}{ll}\text { Figura. } 29 \text { - Fachada da Fazenda Cachoeira } & 59\end{array}$

$\begin{array}{ll}\text { Figura. } 30 \text { - Elevação Fazenda Cachoeira } & 60\end{array}$

$\begin{array}{ll}\text { Figura. } 31 \text { - Elevação da Fazenda Cachoeira } & 60\end{array}$

$\begin{array}{ll}\text { Figura. } 32 \text { - Planta da Fazenda Cachoeira } & 60\end{array}$

$\begin{array}{ll}\text { Figura. } 33 \text { - Foto aérea da cidade que desapareceu } & 110\end{array}$

Figura. 34 - Mapa de localização dos bairros na nova cidade 110

Figura. 35 - Barragem da UHE Nova Ponte 131

$\begin{array}{ll}\text { Figura. } 36 \text { - UHE Nova Ponte } & 131\end{array}$

Figura. 37 e Figura. 38 - Fotos aéreas da nova cidade 140

$\begin{array}{ll}\text { Figura. } 39 \text { - Avenida principal da cidade nova } & 141\end{array}$

$\begin{array}{ll}\text { Figura. } 40 \text { - Foto da maquete } & 141\end{array}$

Figura. 41 - Mapa de localização geográfica da nova cidade de Nova Ponte 143

Figura. 42 - Hospital Municipal da atual cidade $\quad 145$

$\begin{array}{ll}\text { Figura. } 43 \text { - Rodoviária da nova cidade } & 146\end{array}$

$\begin{array}{ll}\text { Figura. } 44 \text { - Fachada da rodoviária } & 146\end{array}$

Figura. 45 - Cemitério São Miguel na nova cidade 149

Figura. 46 - Capela do Cemitério de São Miguel 150 
Figura. 47 - O desmanche do velho cemitério São Miguel

Figura. 48 - Planta do Cemitério de São Miguel da velha cidade

Figura. 49 - Igreja de São Sebastião na velha cidade

Figura. 50 - Igreja de São Sebastião na nova cidade 153

Figura. 51 - Igreja de São Miguel na velha cidade 154

Figura. 52 - Igreja de São Miguel na cidade nova 154

Figura. 53 - A demolição das edificações da velha cidade 160

Figura. 54 - Prefeitura Municipal e Paço da cidade nova 168

Figura. 55 - Prefeitura Municipal da velha cidade até 1993 168

Figura. 56 - Prefeitura de Nova Ponte de 1939 a 1943. Em 1993 era o Sindicato dos produtores rurais da cidade 


\section{ÍNDICE DE TABELAS}

Tabela 01. Localização da população de Nova Ponte em 1950

Tabela 02. Distribuição da população municipal segundo ramos de atividade em 1950

Tabela 03. Dados da produção agrícola do município em 1955 71

Tabela 04. Situação dos rebanhos do município em 1955 72

Tabela 05. Organização industrial em 1955

Tabela 06. Melhoramentos Urbanos - dados de 1955

Tabela 07. Instrução Pública - dados de 1955

Tabela 08. Ensino primário no município de Nova Ponte em 1955

Tabela 09. Relatório final do Grupo de Trabalho Interministerial - GTI (2004) 128

Tabela 10. Distribuição da população municipal (2003) 148

Tabela 11. Distribuição da área municipal (2003) 148 


\section{SUMÁRIO}

Resumo

Abstract

Introdução

Capítulo 1 - O velho lugar: cenas e tempos urbanos, a memória, o cotidiano e a história da cidade de Nova Ponte.

Capítulo 3 - O setor elétrico e o cenário político brasileiro: a definição da categoria dos grandes projetos e a identificação dos atores envolvidos no processo

3.1. Um breve histórico da trajetória do setor elétrico brasileiro: o tratamento dos segmentos sociais afetados 
3. 2. Cronologia: as etapas de planejamento, aprovação e construção da usina e da cidade de Nova Ponte

Capítulo 4 - A conquista do novo lugar: da euforia à saudade

4.1. Uma luta organizada: resultados práticos

4.2. A atual cidade de Nova Ponte

4.2.1. Localização Geográfica

4.2.2. População

4.2.3. Área Municipal

4.2.4. Equipamentos e serviços

4.2.5. Educação, lazer e esporte

4.2.6 Infra-estrutura

4.2.8. Atividades econômicas do município

4.3. A apropriação da nova cidade por seus velhos personagens

Conclusões 
ANEXOS 


\section{Introdução}

O tema escolhido para a pesquisa, "A cidade dos afogados", aborda a história urbana de Nova Ponte e sua constituição nos remete a um passado recente. Em 1993, toda a área urbana da velha cidade de Nova Ponte foi inundada pelas águas da barragem de uma usina hidrelétrica - a UHE Nova Ponte. E sua população foi reassentada na nova cidade construída a três quilômetros da antiga sede.

A pesquisa buscou levantar os impactos sócios - ambientais ocorridos na região que afetaram diretamente os moradores da velha cidade. Estes impactos levaram a organização da população para a reivindicação de seus direitos. E através do movimento SOS Nova Ponte - o movimento dos "afogados" - foi possível pensar a cidade nova como espaço concreto.

A história deste movimento toma corpo no texto e se torna uma peça fundamental na trajetória desta população, rumo à conquista da construção de uma nova cidade, ao se configurar como a única maneira que os atingidos encontraram para dar visibilidade ao tratamento adotado pela concessionária responsável pelo projeto - a CEMIG. A visibilidade alcançada legitimou a luta e as reivindicações através de ações práticas em sua maioria potencializadas pela Igreja Católica.

A partir de Nova Ponte surge o esboço de um novo modelo no tratamento dado aos atingidos pela construção de barragens no setor elétrico brasileiro. A cidade foi a primeira no estado de Minas Gerais, e uma das primeiras no Brasil, a alterar a prática tradicional do setor quanto às pessoas residentes nas áreas afetadas. A prática recorrente consistia na desapropriação das extensões territoriais onde eram instaladas as usinas mediante pagamento de indenizações, sendo concedido aos habitantes um determinado prazo para a migração individualmente programada. Historicamente esta era a forma de remanejamento da população atingida. $A$ negociação entre a empresa e o segmento social atingido tinha como base os direitos de propriedade e o ressarcimento financeiro aos prejuízos passíveis de 
indenização legal, ou seja, dava cobertura apenas aos danos patrimoniais. Aos atingidos, excluídos ou sequer reconhecidos legalmente, restava apenas a mobilização e a pressão política em sua defesa. Em Nova Ponte a atuação da população na negociação com a CEMIG, com uma participação direta, organizada e sistemática, possibilitou a abertura de canais e alterou o rumo das políticas públicas do setor elétrico no estado.

Em um primeiro momento a população da cidade de Nova Ponte não ofereceu resistência à construção da usina e alguns dos motivos diagnosticados foram: a falta de argumentos para barrar uma obra que traria 0 desenvolvimento para a região e para o país, o desconhecimento dos impactos negativos das obras de grande porte e a esperança de que a construção da usina e da nova cidade pudesse trazer progresso à região.

Com o início das obras da barragem tudo mudou, e a continuidade da construção da usina esbarrou na reação da população indignada com a falta de informação sobre seu futuro, com a destruição das quedas d'água, fauna e flora, alteração dos cursos dos rios, diminuição de área produtiva e conseqüente empobrecimento generalizado. A construção provocou a mudança nos hábitos cotidianos, na identidade e nos valores vinculados à velha cidade, alterando o modo de apropriação, uso e representação do espaço.

A pesquisa aborda a questão da temporalidade. O tempo aparece como o elemento estruturador do texto, não apenas como descrição objetiva, mas também como narrativa. E com esta concepção a abordagem do espaço partiu da relação entre o presente e o passado, a velha "Nova Ponte" versus a nova "Nova Ponte". A imagem do passado é construída através da mediação da memória e da narrativa na constituição e representação do seu espaço. Nestas narrativas o olhar nostálgico sobre o passado na cidade velha se defronta com o presente, a diferença dos traçados, a sociabilidade e a mudança da vida cotidiana. No presente, a cidade nova revela o almejado progresso e a "modernidade" nas construções, mas também, deixa transparecer a falta de enraizamento e o desencontro dos seus moradores. 
A pesquisa trabalha em um contexto de questões urbanas específicas: 0 desenho urbano e seu traçado a partir da mediação e da participação popular potencializados no presente recente; investiga a questão do patrimônio arquitetônico edificado, sua preservação e reutilização; levanta a questão da reconstrução da cidade e a tensão entre a manutenção da sociabilidade estabelecida no velho lugar e suas redefinições, transformações e dimensões inerentes à cultura local, às características locais e nas identidades preservadas e/ou construídas em um novo espaço.

Entrevistas foram realizadas com as lideranças do movimento popular da cidade, alguns moradores, pequenos agricultores, comerciantes, donas de casa e funcionários públicos. Estas entrevistas objetivaram "levar em conta a verdade de que nada do que um dia aconteceu pode ser considerado perdido para a história" (BENJAMIN, 1987, p.197-232). Considerando o fato de que a memória reinventa e interpreta fatos, e que os relatos históricos, em sua maioria, se baseiam na versão do dominador ou vencedor, estas narrativas puderam abrir um canal capaz de evidenciar uma versão distinta da versão "oficial", contribuindo para que a memória individual ou coletiva fosse registrada como a memória histórica da cidade de Nova Ponte.

Para Benjamin, esta narrativa seria "uma forma artesanal de comunicação" que não está interessada em transmitir a "coisa narrada" como uma informação ou um relatório, mas mergulha nos fatos e imprime na narrativa a marca do narrador. "O grande narrador tem sempre suas raízes no povo", e é comum a todos eles, a imagem de uma experiência coletiva. Todos os narradores recorreram à experiência coletiva, à experiência que passa de pessoa a pessoa, e "entre as narrativas escritas, as melhores são as que menos se distinguem das histórias orais contadas pelos inúmeros narradores anônimos".

A pesquisa buscou uma reflexão sobre a construção da memória e da experiência / vivência, em um período de iminente destruição dos laços espaciais e sociais, buscando respaldo na reconstituição das memórias através de narrativas da população sobre a cidade e seus bairros e na relação dos moradores com estes espaços. A narração "não tem a pretensão de transmitir 
um acontecimento, pura e simplesmente, mas integra-o à vida do narrador para passa-lo aos ouvintes como experiência" (BENJAMIN, 1987, p.197-232). Algumas narrativas de moradores de Nova Ponte foram transcritas para 0 texto. O critério de escolha das entrevistas foi baseado na participação desses sujeitos no processo de reassentamento durante o período abordado. A organização do texto foi estruturada nestas narrativas sobre a cidade e seus bairros, as histórias individuais e coletivas e as memórias que de uma maneira fragmentada procuraram descrever a experiência da cidade, seus modos de vida como "reflexões, percepções, julgamentos e imagens" ${ }^{1}$.

A escolha dos textos de Benjamin busca justificar o modo como a teoria dialoga com o trabalho de campo. Nos textos o "Narrador" e "Sobre o conceito da história" (1987), Benjamin faz uma reflexão sobre as relações entre a memória e a cidade, sobre o papel do historiador e uma crítica ao conceito de história e de historiografia. Foram realizadas as entrevistas com lideranças e moradores na busca de uma aproximação com as noções de Benjamin.

A transcrição dos relatos foi organizada por temas e foram transcritos apenas trechos escolhidos pela clareza das informações e importância do conteúdo. Esta organização procurou estabelecer um vínculo entre a narrativa e a experiência da cidade.

As informações foram coletadas com os moradores da nova cidade durante entrevistas livres com duração de aproximadamente três horas cada. As entrevistas se referiram basicamente à vida cotidiana da cidade e/ou bairro, comentários sobre fotos, documentos e objetos de memória do lugar. Foram encontrados fragmentos indígenas e até tijolos de moradias da cidade que desapareceu em algumas das residências dos entrevistados. Estes fragmentos foram cuidadosamente preservados formando pequenos "acervos" de "museus" particulares.

Através do Livro Memória do Cotidiano, elaborado pelo Projeto Memória Histórica de Nova Ponte, da Escola de Arquitetura da Universidade de

\footnotetext{
${ }^{1}$ BENJAMIN (1987).
} 
Minas Gerais - EA / UFMG - através do Departamento de Análise Crítica e Histórica (1987/88), que tem seus originais preservados no Arquivo Público de Nova Ponte, a pesquisa buscou elementos que permitiram uma "viagem no tempo". Esta viagem possibilitou a análise do local que desapareceu e a definição de uma imagem da cidade velha, sua configuração urbana, seus edifícios e sua arquitetura, as fronteiras de seus espaços públicos e privados, suas interpenetrações e transformações, evidenciando os modos de construção das identidades ligadas ao velho "lugar".

O trabalho de campo resultou em um amplo acervo de material jornalístico do período, que envolveu a análise, a leitura e, como resultado, alguns destes artigos podem ser encontrados transcritos no decorrer do texto. A pesquisa envolveu também a leitura de documentos oficiais, da legislação ambiental, de projetos e programas elaborados pela CEMIG, além dos documentos, textos de divulgação, jornais de circulação interna da empresa e boletins produzidos pela estatal.

A pesquisa buscou documentar que em Nova Ponte a tradição e a cultura local, o acesso às instâncias de poder regional e a tentativa de preservar o seu modo de vida foram determinantes na luta pela construção da nova cidade, que foram potencializadas pela Igreja Católica. Houve o medo de que as indenizações pagas pela CEMIG fossem insuficientes para a compra de terras pelos desapropriados. Além da falta de informações e o desconhecimento dos critérios para o pagamento das indenizações, a perspectiva de migração involuntária, a perda dos meios de sobrevivência, a separação da família e dos amigos, a percepção das perdas pelos atingidos também incluiu a diminuição das terras férteis, de mão de obra investida, os impactos e a possível perda da vida comunitária, da identidade e dos valores vinculados ao lugar.

O primeiro capítulo conta a história da velha cidade, com seus personagens, praças, ruas e bairros, através das narrativas dos antigos moradores. O que resultou na definição de identidades fortemente "ancoradas" no lugar, que reforçam as sociabilidades construídas onde "todos eram conhecidos, eram parentes". Abordou a questão da temporalidade e do 
afogamento, ou seja, do rompimento e término, com a morte anunciada da velha cidade, e a frustração da população diante da perspectiva de crescimento e desenvolvimento contrapondo-se à incerteza do futuro.

No segundo capítulo o texto evidencia a relação entre o espaço público e o privado, suas alterações e inter-relações a partir da transformação de seu modo de vida e, considerando os impactos sofridos pelos atingidos com o início das obras da barragem, com a construção da vila operária e com a chegada dos "peões" na velha cidade.

No terceiro capítulo a pesquisa aborda a implantação dos grandes projetos do setor elétrico no Brasil, com um recorte no período de interesse da pesquisa, além de um olhar crítico para tratamento dado aos segmentos sociais atingidos durante a construção de barragens. Neste estudo de caso da implantação da UHE Nova Ponte, o texto documenta os caminhos percorridos por sua população. Durante a definição de sua transferência da velha para uma nova cidade. A pesquisa registra a experiência participativa da população que foi capaz de construir canais de interlocução com a CEMIG e interferir no planejamento da própria cidade. Em um contexto de mudanças, foi necessário fazer um recorte na história recente sobre as políticas públicas adotadas para o setor elétrico brasileiro, objetivando enfatizar a importância do processo ocorrido na cidade de Nova Ponte.

O quarto capítulo buscou documentar o processo de relocação, da velha para a nova cidade planejada. Foi tratado através da análise da apropriação do novo lugar, da tentativa de preservação da identidade e das sociabilidades construídas na velha cidade. Discutiu a possibilidade ou impossibilidade da manutenção de velhos hábitos cotidianos em um novo espaço. A narrativa procurou, através da fala dos moradores, abordar o processo de transferência adotado pela CEMIG. 


\section{Capítulo 1}

\section{O velho lugar: cenas e tempos urbanos, a memória, o cotidiano e a história da cidade de Nova Ponte.}

A trajetória da população de Nova Ponte, a sua luta e a sua organização social se inserem no cenário político brasileiro onde, segundo DAGNINO (2002) a sociedade brasileira, marcada pela experiência autoritária do regime militar, se organizou em uma luta unificada contra o autoritarismo a partir da década de 70 , que reuniu diversos setores sociais em vários tipos de movimentos como os sindicatos de trabalhadores, associações de profissionais, universidade, Igrejas, etc. $\mathrm{Na}$ década de 80 , a redefinição da noção de cidadania empreendida pelos movimentos sociais baseava-se no reconhecimento dos seus membros como "sujeitos portadores de direitos", e como conseqüência concreta houve a emergência de novas experiências na construção de "espaços públicos". Novos atores começavam a ocupar os espaços públicos nos movimentos sociais através de suas linguagens, dos lugares onde se manifestavam e indicavam a emergência de novas identidades coletivas. Estes grupos populares "irrompiam a cena pública reivindicando seus direitos, a começar pelo direito de reivindicar direitos" ${ }^{2}$.

O surgimento de organizações populares em Nova Ponte, na década de 80 , pressupõe o surgimento de uma cultura local mais democrática e participativa, apoiada no exercício e na criação de direitos. A Igreja Católica teve o papel de potencializar o movimento e se constituiu em um ponto de ancoramento e convergência de práticas e discursos diferenciados. Estas práticas e discursos ajudaram a construir o tempo histórico que produziu 0 movimento como acontecimento significativo. Aqui as noções de organização, participação e ação coletiva não brotaram de experiências vividas em conflito

\footnotetext{
${ }^{2}$ SADER (1995).
} 
com o poder local. No exemplo de Nova Ponte, a experiência de organização da população assumiu forma e se articulou intimamente com o poder municipal, caracterizando uma partilha do poder político, com um alto nível de participação e práticas igualitárias. Essa seria uma forma que se aproximaria das práticas da democracia direta, pelo acesso e uso do poder político, promovendo novas condições econômicas, sociais e culturais da população, ainda que à custa de muitas perdas. Os resultados foram evidentes, do ponto de vista político e social, dessa participação organizada na administração das negociações e que revelou sua potencialidade transformadora ${ }^{3}$.

Nos anos 70, um dos fatores mais importantes para o desenvolvimento dos processos políticos em toda a América Latina foi a incorporação dos setores de inserção religiosa organizados no trabalho do movimento popular. $O$ comportamento da Igreja brasileira simbolizou e resumiu uma série de experiências e passou de um compromisso individual de certas personalidades da hierarquia a uma participação ampla com profunda dimensão nacional das organizações eclesiais de base ${ }^{4}$, o que abriu um canal de expressão a setores sociais novos do movimento popular brasileiro, entre 1968 e 1973, quando as forças do cristianismo popular começaram a desenvolver-se e a conquistar uma implantação orgânica. A Igreja no Brasil, nas décadas de 70 e 80 , se deslocou de uma posição de integrante de um modelo de dominação política das elites dirigentes, passando de uma concepção conservadora do mundo para uma postura reformadora. E foi através deste processo que a lgreja passou a desempenhar um papel de relevo no desenvolvimento político da sociedade brasileira, tendo como principal conseqüência o nascimento de uma rede de organização popular:

Através de um processo que ainda permanece pouco conhecido, surgiu possivelmente a partir de 1969, uma progressiva articulação das classes populares. Esta articulação se processou de forma autônoma, com conteúdos específicos, dentro dos novos modelos de organização... Nasceu do povo, isto é, dos camponeses pobres e trabalhadores rurais, dos

\footnotetext{
${ }^{3}$ SOUZA (1982).

${ }^{4}$ MAIRA (1982).
} 
operários urbanos, bóias-frias, favelados, etc. Chegou-se a discutir se a origem principalmente camponesa do movimento impossibilitaria sua expansão nas cidades (LIMA, 1982, p.4172).

A história dos anos 70 poderia ser vista como a "constituição do social como espaço político" 5 , e esse social constituído enquanto espaço de reconhecimento, de afirmação e exigência de direitos, constituiria também as noções de autonomia, de ação e participação coletivas, de democracia de base. 6

Em Nova Ponte, as teias de solidariedade que se agregaram em associações se formaram em torno de problemas comuns, como os que reivindicavam justas indenizações e a construção da nova cidade. O estudo da história e da memória do "lugar" registrou o cotidiano dos moradores da velha cidade e evidenciou uma forte identidade cultural. A análise deste cotidiano possibilitou desvendar conexões de múltiplos significados que foram reforçados com a inserção de novos desafios enfrentados pela população por pertencerem a uma cidade que iria desaparecer.

Esta luta direcionada ao exercício e a criação de direitos colocou em xeque a questão da terra, habitação e os bens de consumo coletivo ${ }^{7}$.

No conflito é que o enigma dos direitos se decifra, enquanto conquista de reconhecimento e legitimidade, sem o que, a cidadania formulada nos termos da lei não se universaliza e não tem como se enraizar nas práticas sociais (...). Constitui o próprio campo dos conflitos: é em torno da medida do justo e do injusto que a reivindicação por direitos é formada, os

\footnotetext{
${ }^{5}$ Segundo TELLES (1988): "Incorporavam, re-elaboravam e re-codificavam o conjunto de significados corporificados em práticas e discursos que teciam o campo de experiências no qual a movimentação popular incidia e ajudava ao mesmo tempo a construir".

${ }^{6}$ De acordo com TELLES (1992): "Depois de quinze anos de repressão, uma conflituosidade inédita atravessou as mais diversas dimensões, a exigência por uma ordem de vida mais justa e mais igualitária. A partir daí, a questão social ganhou dimensão institucional evidente enquanto dívida social a ser resgatada".

7 "... qualquer grupo - por exemplo, de mulheres que clamam por creches ou negros que se encontram espacial e socialmente segregados de modo particular - pode estabelecer como pauta de reivindicação um problema urbano. Suas reivindicações podem ser pontuais quanto aos objetivos e aos locais da cidade ou, ao contrário, adicionar organizações díspares que passam a lutar por benefícios múltiplos e coletivos" (KOWARICK, 2002).
} 
embates se processam e se desdobram numa negociação possível (TELLES, 1992, p.247-285).

A possibilidade da ação conjunta entre os poderes locais e a sociedade civil, como no exemplo de Nova Ponte, seria uma característica que estaria surgindo fortemente a partir anos 90 .

\subsection{A formação do município}

Foram dois os núcleos que deram origem à cidade de Nova Ponte: 0 arraial de São Miguel e o de São Francisco. Em margens opostas do rio Araguari - naquela época denominado rio das Velhas - os moradores e fazendeiros, Manoel Pires de Miranda e Antônio Luciano de Rezende, doaram uma gleba de terra da fazenda da Cachoeira para a construção da capela de São Miguel; na outra margem do rio, os fazendeiros Nephtali José de Castro e Joaquim de Almeida doaram o terreno para a construção da capela de São Sebastião.

Ligando os dois povoados, foi inaugurada em 1858, uma ponte de madeira construída por Antônio José da Silva Fernandes. O construtor ficou com os direitos de cobrança de pedágio para travessia da ponte por trinta anos. Essa ponte de madeira serviu por 46 anos, ruindo em 1904; em 1908, no governo João Pinheiro, foi inaugurada a ponte de estrutura metálica que desapareceu com a velha cidade ao ser inundada.

O distrito de São Miguel de Nova Ponte teve sua criação em 26 de setembro de 1882, sendo subordinado ao município de Sacramento ${ }^{8}$. Manifestações por autonomia nas décadas de 20 e 30 conseguiram nomear o distrito de Nova Ponte. O distrito teve o seu topônimo alterado para Nova Ponte em 7 de setembro de $1923^{9}$, permanecendo subordinado ao município de Sacramento até 17 de dezembro de $1938^{10}$, quando o Presidente da República Getúlio Vargas emancipou os distritos e constituiu o município. Foi criado o

\footnotetext{
${ }^{8}$ Lei provincial ํำ 2916, confirmada pela Lei $n^{\circ} 2$ de setembro de 1891.

9 Lei estadual ํㅛ 843.

${ }^{10}$ Decreto-lei no 148.
} 
município de Nova Ponte anexando também o distrito de São Sebastião que foi desligado do município de Monte Carmelo. O município passou a compor-se apenas de um distrito, o da sede, subdividido em duas zonas: Nova Ponte e São Sebastião; situado na Zona Alto Paranaíba do Estado de Minas Gerais, com uma área de $1.159 \mathrm{Km}^{2}$ e distante $405 \mathrm{Km}$ da capital Belo Horizonte.

A população do município de Nova Ponte, segundo os dados do Recenseamento de 1950, era de 7.950 habitantes e segundo as estimativas do Departamento Estadual de Estatística de Minas Gerais, sua população provável em 1955 seria de 8.372 habitantes, com densidade demográfica de sete habitantes por quilômetro quadrado.

O fato da região se configurar, desde o início da sua formação, como área de passagem para outras regiões se exacerba com a construção da usina, devido também ao caráter transitório da atividade barrageira. A esperança dessa população foi depositada na possibilidade de progresso futuro, com a construção da grande usina hidrelétrica que teve sua viabilidade garantida diante da insuficiência da oferta de energia elétrica regional e nacional, e da construção da nova cidade.

\subsection{A velha cidade com seus cenários e personagens}

A antiga cidade de Nova Ponte, contava com aproximadamente 3 mil e 500 habitantes e cerca de mil lotes. Na primeira proposta da CEMIG a nova cidade teria aproximadamente 1.800 lotes, incluindo aí 76 lotes industriais que permitiram alocar micro-empresários da região, dentro dos padrões modernos de urbanismo e toda a infra-estrutura necessária ao bem estar de uma comunidade.

Com 980 prédios, 1 banco, 8 indústrias, 30 estabelecimentos comerciais, 1 hospital da Fundação Municipal de Saúde, 19 estabelecimentos de ensino do $1^{\circ}$ grau, 1 colégio estadual de $2^{\circ}$ grau e 1 pré-primário, Nova Ponte era o mais novo município do Estado a ser assumido pela CEMIG. A transferência, para o 
outro local de toda a população urbana residente na área que seria inundada pelas águas do lago a ser formado, ocorreria a partir de 1991.

O prefeito de Perdizes, cidade próxima à Nova Ponte, João Custódio da Silva chegou à seguinte conclusão e declarou a um jornal local" : "a construção da hidrelétrica da CEMIG pode ser comparada com a seca do Nordeste, quanto mais longe melhor".

A mudança para um novo lugar, segundo Rebouças (2000), traz em si uma ruptura na morfologia social que estava inscrita na organização do espaço doméstico, na disposição dos diferentes domínios e no controle de seus trajetos e códigos, estabelecendo uma nova distribuição entre diferentes espaços que compõem o cotidiano da comunidade, resultando em novas apropriações e representações ${ }^{12}$. O primeiro pressuposto teórico é o de que os sistemas simbólicos, no interior dos quais elaboram-se as noções de espaço, são constitutivos da vida social e são usados como modelos tanto para a representação de uma realidade, quanto para comportamento e ação.

Na nova cidade nem todos são conhecidos ou parentes. Não há mais na área urbana do município muito de sua área rural: os lotes agora têm áreas menores, os quintais foram sacrificados às casas e as hortas, aos jardins frontais. Essa mudança provocou uma modificação nos hábitos dos moradores da cidade. O fazendeiro João Magalhães Resende, Seu João Jacó, por exemplo, teria de abdicar do leite tirado da vaca no fundo do quintal, do pomar de 200 árvores e das criações de animais que tinha em casa.

A experiência de vida do Seu João Jacó, enraizada no velho lugar, não tinha preço: "O governo não tem dinheiro para me pagar essa chácara, porque eu não a venderia de jeito nenhum", afirmava.

Mesmo não correndo o risco de ser inundado, o Bairro de São João também foi relocado pela CEMIG. Neste bairro foi registrada a maior resistência à mudança da cidade, a exemplo do Sr. Sebastião Firmino, um trabalhador rural que se recusou a mudar de casa e contou com o apoio de

\footnotetext{
${ }^{11}$ Recorte de jornal arquivado no Museu Rural de Nova Ponte s.d.

${ }^{12}$ Ver Thompson, E.P. Costumes em Comum. Cia das Letras. São Paulo, 1998.
} 
vários vizinhos. Mesmo assim, com a construção da represa houve a mudança, e a distância da casa do Sr Firmino para a cidade aumentou de três para dezoito quilômetros, o que dificultou o acesso de seus filhos à escola, ao hospital e aos outros serviços na nova cidade.

Em declaração dada ao Jornal de Goiás, em 19 de outubro de 1991, o funcionário da CEMIG ${ }^{13}$ Joanito Campos Júnior, lembrou que Nova Ponte foi iniciada em 1983, numa época em que não se pensava em fazer e/ou permitir o envolvimento ideal da população atingida na solução conjunta do reassentamento involuntário. Na ocasião, explicou a decisão de inundar a cidade teve em vista basicamente o benefício que a nova hidrelétrica traria, como trouxe, a mais de 15 milhões de pessoas, somente em Minas: "Hoje dentro da visão ambiental que predomina em todos os setores da empresa, se soubesse o custo social que foi a mudança dos habitantes locais, a barragem seria construída de outra forma, talvez. Ela poderia ser locada à montante da cidade e não à sua vazante, como aconteceu, mesmo que isso significasse menos produção de energia”.

Na região que seria alagada, a CEMIG, Leme Engenharia e CETEC Centro Tecnológico de Minas Gerais -, realizaram uma série de estudos ligados à população da cidade e ao meio ambiente, com a colaboração da UFMG ${ }^{14}$ Universidade Federal de Minas Gerais - que levantou toda a história do município, desde a sua fundação com a participação ativa da população:

Durante dois anos, 1987 e 1988, pesquisou-se a origem e a evolução da cidade, recolheram-se suas principais referências urbanísticas e arquitetônicas, compreendeu-se seu cotidiano e registraram-se os marcos físicos, afetivos e memoriais daquela cidade (BRANDÃO, 1997, p.11).

\footnotetext{
${ }_{14}^{13}$ Assistente da presidência da CEMIG.

${ }^{14}$ Através de convênio entre Leme Engenharia e a Escola de Arquitetura da Universidade de Minas Gerais - EA-UFMG - e seu Departamento de Análise Crítica e Histórica, para a elaboração do Projeto Memória Histórica de Nova Ponte, que resultou em cinco volumes: Apresentação; Momento histórico da construção da Usina Hidrelétrica de Nova Ponte; Memória urbana; Memória arquitetônica e Memória do cotidiano. Documentos que atualmente se encontram no Arquivo Público de Nova Ponte.
} 
O rio Araguari dividia a velha cidade em dois subdistritos: de um lado do rio, ficavam os bairros de São Miguel - o Centro -, Nossa Senhora do Rosário o Gravatá - e São Francisco - o Morro de Pedra -, que configuravam o subdistrito de São Miguel; do outro lado do rio, no subdistrito de São Sebastião, estavam os bairros São Sebastião e São João - Três Moitas. No subdistrito de São Miguel, os lotes tinham em média $1.000 \mathrm{~m}^{2}$, galinhas atravessavam 0 asfalto, maritacas faziam algazarra nos fios elétricos e nas goiabeiras das casas da praça, um milharal podia ser avistado no quintal de uma delas, também podiam ser encontrados nas casas da cidade galinheiros, chiqueiros, horta, pomares e, estacionados lado a lado em frente aos estabelecimentos comerciais, encontravam-se carros e cavalos. Havia muito de área rural na área urbana (Figura. 11).

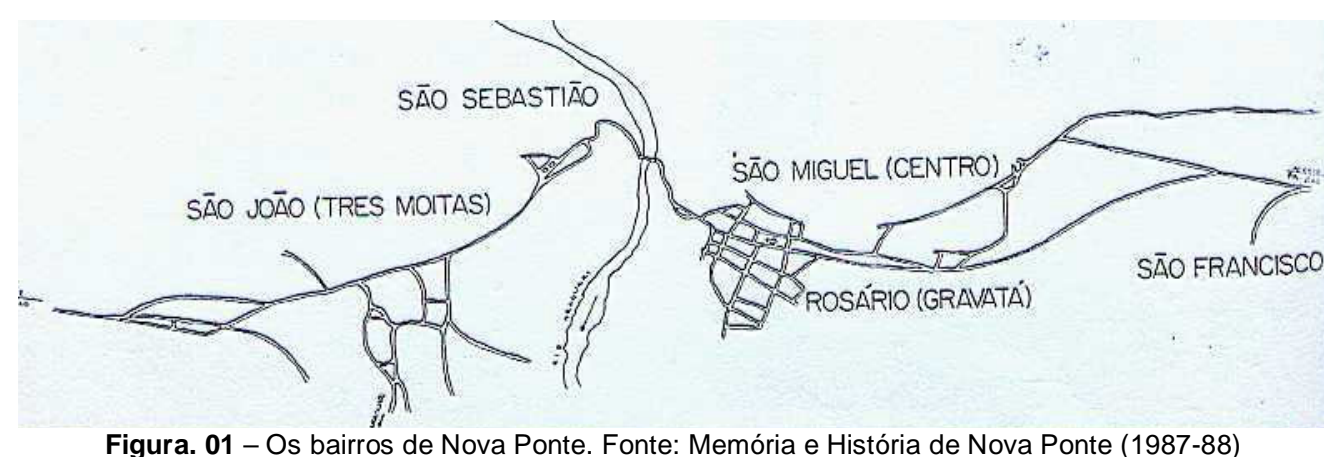

O Bairro São Miguel ${ }^{15}$ :

O centro, como era conhecido o Bairro São Miguel, era o lugar em que o comércio se concentrava, para onde todos se dirigiam, onde estava o "jardim" a Praça São Miguel (Figura. 02) e os banquinhos em que se assentavam as pessoas para "palestrar" depois das cinco horas da tarde: "A praça mesmo da igreja é o lugar mais importante da cidade. Os meninos jogam bola lá. O povo todo vai lá" (Olíria Maria de Jesus) ${ }^{16}$. Depois do jornal na televisão, a "velha guarda" de Nova Ponte costuma se reunir na praça. Há territórios particulares no jardim (Figura. 03): "Tem um ponto onde eu sempre fico, um banco, o primeiro à esquerda, em frente ao cartório. Eu gosto de lá porque naquela casa funcionou o fórum. O meu serviço ainda é ali”.(Morse Caetano).

\footnotetext{
${ }^{15}$ Baseado no Livro Memória do Cotidiano, elaborado pelo Projeto Memória Histórica de Nova Ponte, Escola de Arquitetura da Universidade de Minas Gerais - EA-UFMG - através do Departamento de Análise Crítica e Histórica (1987/88).

${ }^{16}$ Moradora do bairro em entrevista para o Projeto Memória Histórica de Nova Ponte (1987).
} 


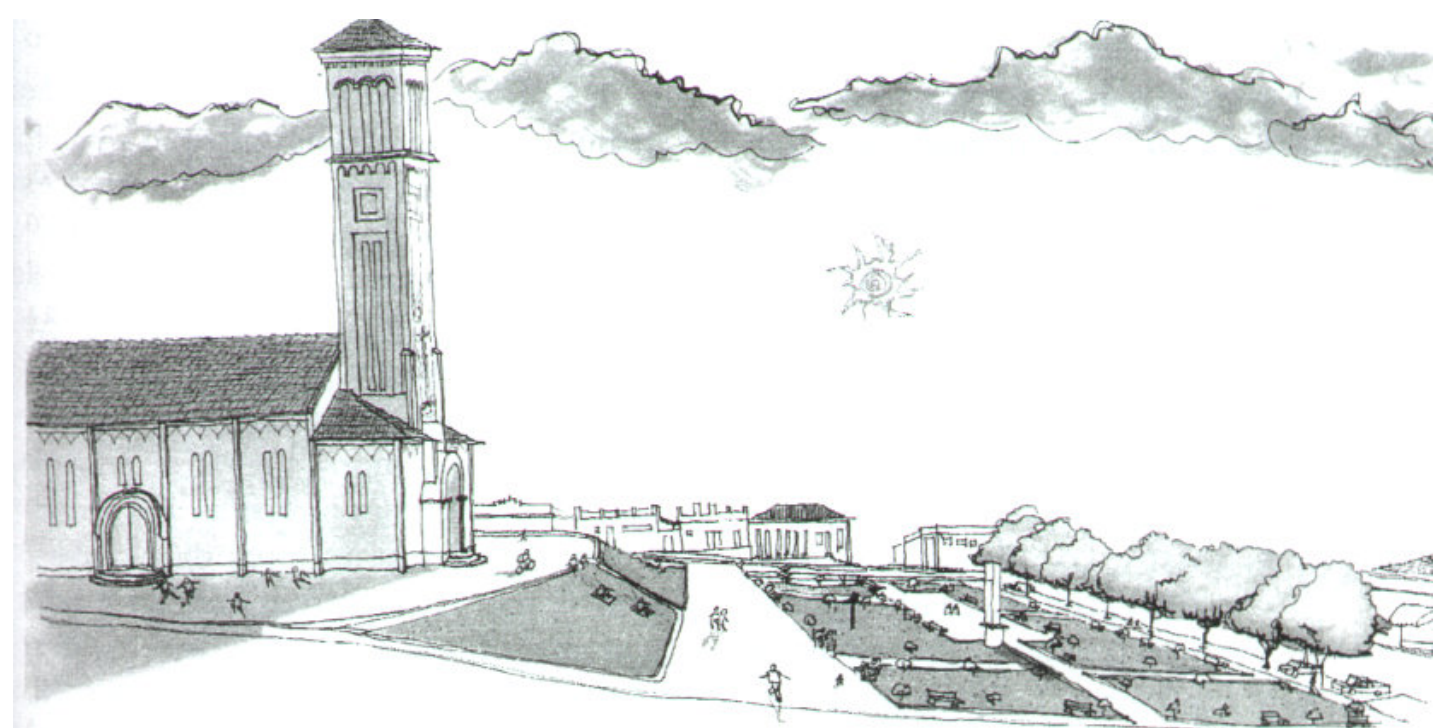

Figura. 02 - Praça São Miguel. Imagem sem autor. Fonte: Memória e História de Nova Ponte (1987-88)

O jardim é paisagem de uma vida inteira. Nele cabem todas as intenções: o brinquedo, a paquera, o namoro, o 'ver o movimento', o descanso, a palestra... A localização da praça, envolvida por eventos - a missa, o movimento na rua principal possibilita e favorece as mais diversas apropriações de seu espaço. O gramado é campo de futebol; o adro, pista de bicicleta e salão de encontros; o guarda-corpo da escadaria, escorregador. Os bancos são ao mesmo tempo sofás: lugar de namoro, descanso e conversa; janelas, lugar de onde se observa a rua e se cumprimenta quem por ela passa, e esquinas, lugar de encontro. A praça é casa, quintal e rua (BRANDÃO, 1997, p.97). 


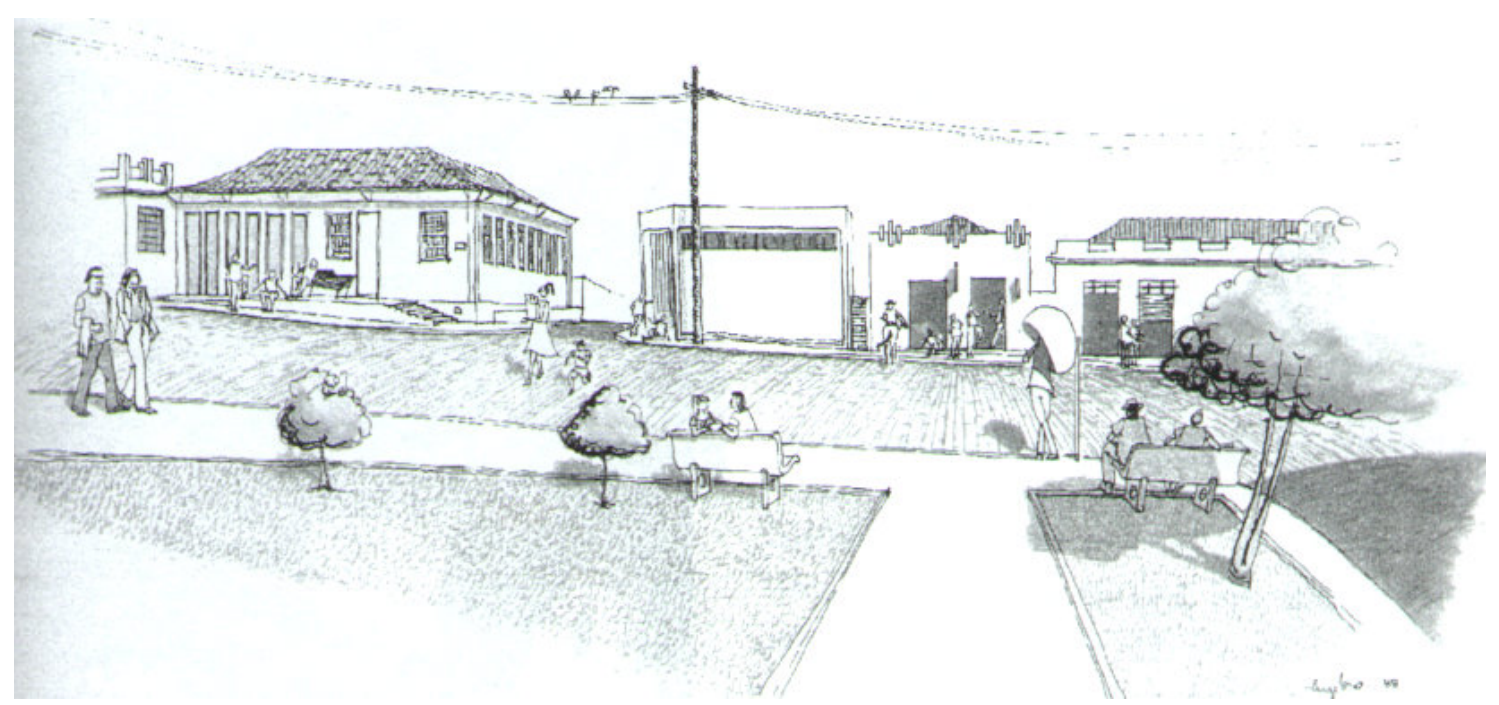

Figura. 03 - A praça São Miguel, seus bancos e esquinas. Sem autor. Fonte: idem, (1987-88).

Na rua principal, a Rua Governador Valadares, ficava a Farmácia São Sebastião de propriedade do Seu Edson, que mantinha próximas à porta duas cadeiras. Trata-se de uma tradição de mais de trinta anos quando ainda era um armazém de secos e molhados: "as cadeiras estão aí para o pessoal que vem conversar e tomar um cafezinho", contava o Seu Edson. Próximos à esquina com a Rua Manoel Pires de Miranda se encontrava o Bar do Geraldo e o do Nereston, a Pensão Nova Ponte, a loja Móveis Pena (Figura. 04), a Farmácia Droganova (Figura 05) e a barbearia do Seu Eduardo, esse cruzamento se destacava no bairro. A Droganova também possuía sua "sala de estar" como a Farmácia São Sebastião e na loja de móveis os fregueses, os funcionários e seus proprietários se sentavam nos móveis expostos dentro e fora da loja, à sombra, para verem o movimento. No pequeno bar do Seu Nereston, os fregueses tomavam sorvete que ele próprio preparava, ao lado do bar ficava sua casa, que se comunicava por uma escadinha com seu comércio. Assim como a Casa São Miguel, loja do Seu Getúlio: "Minha casa é emendada com a loja. Acho bom, fico lá e aqui. No tempo dos outros era assim também. $O$ movimento aumenta é de tarde. Antigamente o povo sentava aqui, conversava um pouquinho. Hoje, eu tenho esses banquinhos aí" (Getúlio Alves do Nascimento). A maioria dos estabelecimentos comerciais na cidade velha era 
continuação da casa de seu proprietário e pouca diferença havia entre a hospitalidade do "dono da casa" e a do "dono do estabelecimento". A loja do Reginaldo, a Casa Santos, também estava próxima à praça e fez parte da paisagem da cidade por mais de três gerações.

$\mathrm{Na}$ esquina das ruas Presidente Vargas e Governador Valadares, a Casa Santos, o Bar do Bitinha e o cartório eram outros lugares que se destacavam no bairro. De tarde nessas esquinas, nos bancos de madeira, pessoas se sentavam onde havia sombra para assistir ao movimento enquanto outras conversavam. "A praça São Miguel e o bar do Bitinha (Figura. 06) em diversos horários, cumprem a função de posto de observação e ponto de encontro" ${ }^{17}$. De dentro do Bar do Bitinha era possível enxergar a praça, ver o que se passa na rua e na praça, mas quase não se viam mulheres no bar: "Só nos fins de semana que vem algum casal ou moça de família aqui, as meninas vão ao Kuka's, que é mais apropriado", explicava o próprio Bitinha - o seu estabelecimento era considerado um espaço masculino.

Na Rua Benjamin Constant estavam localizados: o Banco Bamerindus, a Casa Rural, o salão paroquial, a Biblioteca Municipal, o Sindicato Rural, o Banco do Brasil, o cartório do Seu Salomão, o clube Associação Atlética Novapontense e o bar sacra. Entre o clube e o bar, a Drogaria São Pedro, conhecida como Farmácia do Seu Hélio mesmo com novo proprietário conservava a "sala de estar" com um banco de madeira próximo à porta, quase sempre ocupado. Na esquina com a Rua 17 de dezembro, no armazém do Zé Roxinha com seus quarenta anos de funcionamento, também eram encontrados banquinhos de madeira onde os fregueses se sentavam para a "conversinha do final de tarde". Na Rua Floriano Peixoto e na Rua Sacramento as calçadas estavam sempre ocupadas depois das cinco horas da tarde, meninos andavam de bicicleta, donas de casa eram avistadas descendo a rua até o Armazém do Loura ou se encaminhavam para o Armazém do João Tarcísio e outras que chegavam à janela para cumprimentar as que passavam na rua. Os homens na volta do trabalho faziam uma "rodinha ali no beco", no Bar do Tázio, enquanto moças e rapazes ocupavam os bancos na calçada. "O

${ }^{17}$ Livro Memória do Cotidiano de Nova Ponte (1988). 
trânsito relativamente pouco intenso deixava a rua livre para os pedestres". A "turma da sinuca", ia de tarde para o Bar do Rodão. Da janela de sua casa, o Seu João sapateiro atendia seus fregueses.

Na esquina da Rua Sacramento, há um salão de forró: "O pessoal de São Francisco prefere os forrós. O forró é bom porque mulher não paga. $O$ pessoal lá de baixo, do centro, é que freqüenta o clube. Lá só tem discoteca e música lenta. Gosto mais de forró" (Maria Elsa Vieira). A mercearia São Tarcísio - o armazém do João Tarcísio - teve o mesmo proprietário por dez anos, eram muitos seus fregueses: "muitos conhecidos da roça e da cidade vêm aqui para bater papo na parte da tarde", contava Seu João Tarcísio. Na esquina com a Rua Presidente Vargas ficava a padaria - a Panificadora Naves: "A padaria é muito antiga. Deve ter uns 30 anos esta padaria aí na esquina. Tem de tudo o que você quiser lá. Aqui na rua, para indicar um lugar, a gente fala: 'fica perto da padaria, fica perto do Seu Rodão" (José de Assis Cardoso, antigo morador da Rua Sacramento). O São Miguel, também se caracterizava por ser um bairro residencial, era ao mesmo tempo centro e bairro, espaço público e familiar. (As principais referências do bairro podem ser visualizadas na Figura. 07).

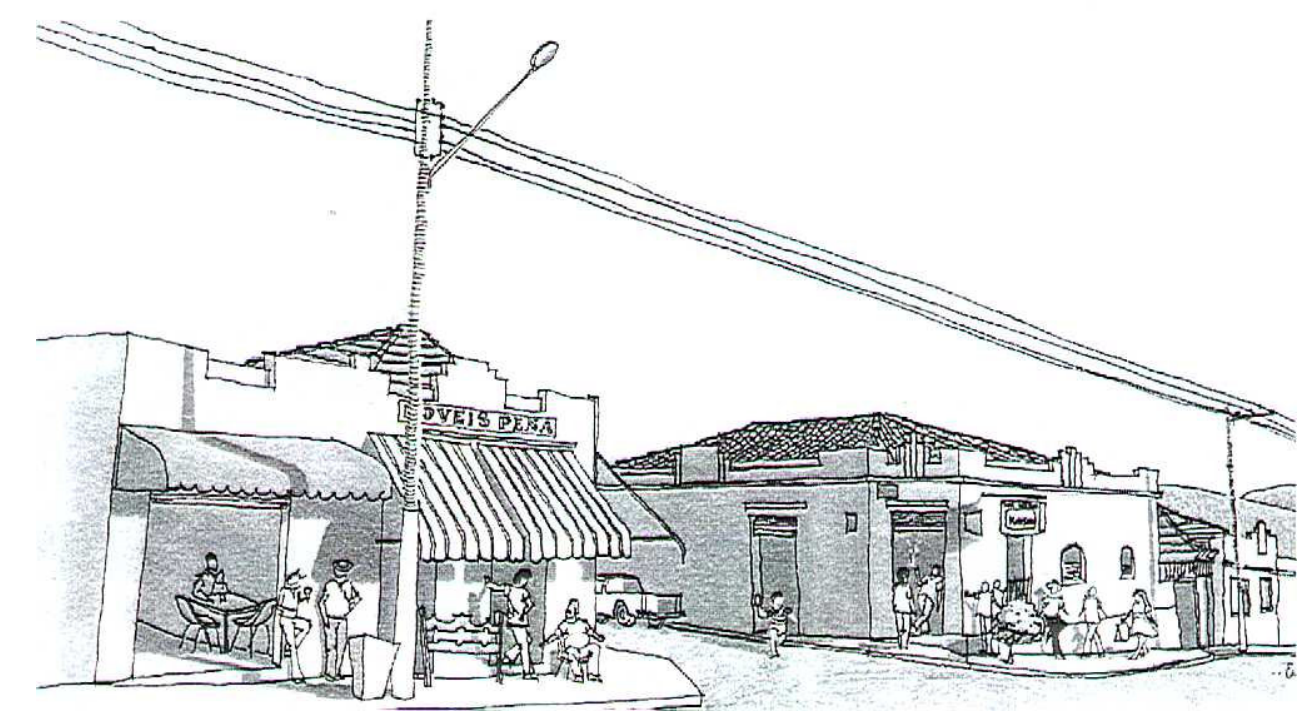

Figura. 04 - Loja Móveis Pena. Imagem sem autor, extraída do Livro Memória e História de Nova Ponte (1987-88). 

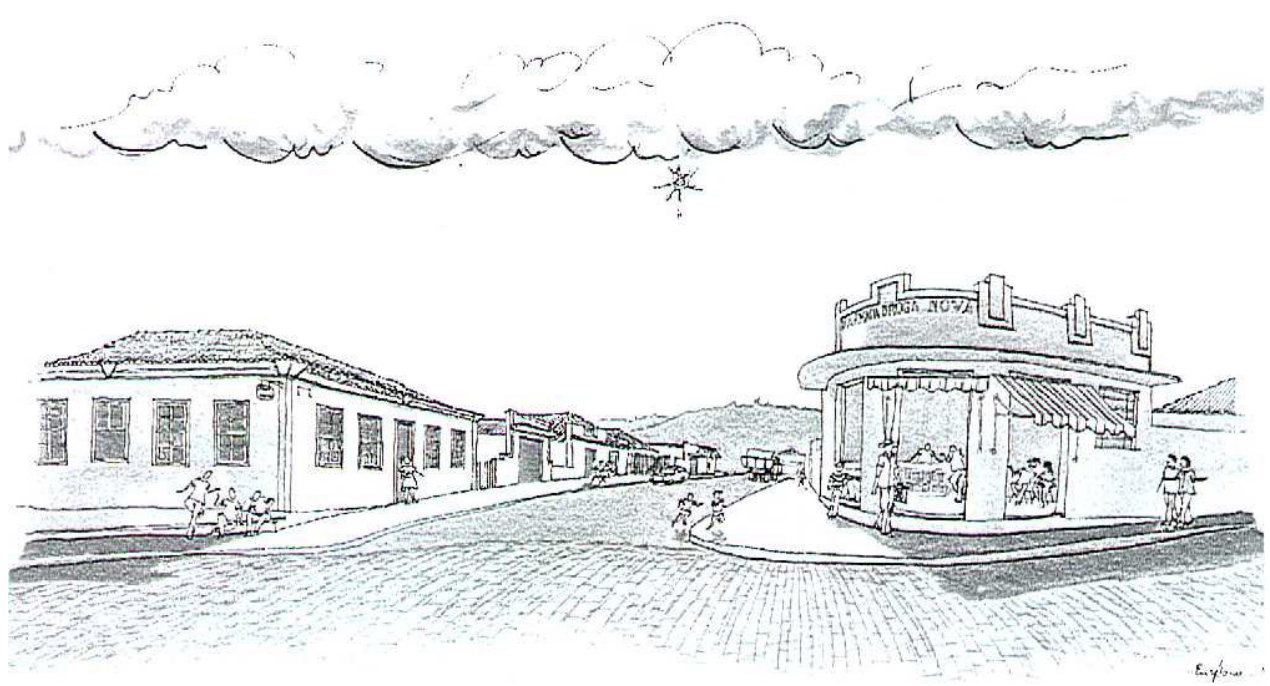

Figura. 05 - F́armácia Dróganóva. Imagem de autor desconhecido. F́ Fonte: idem, (1987-88).

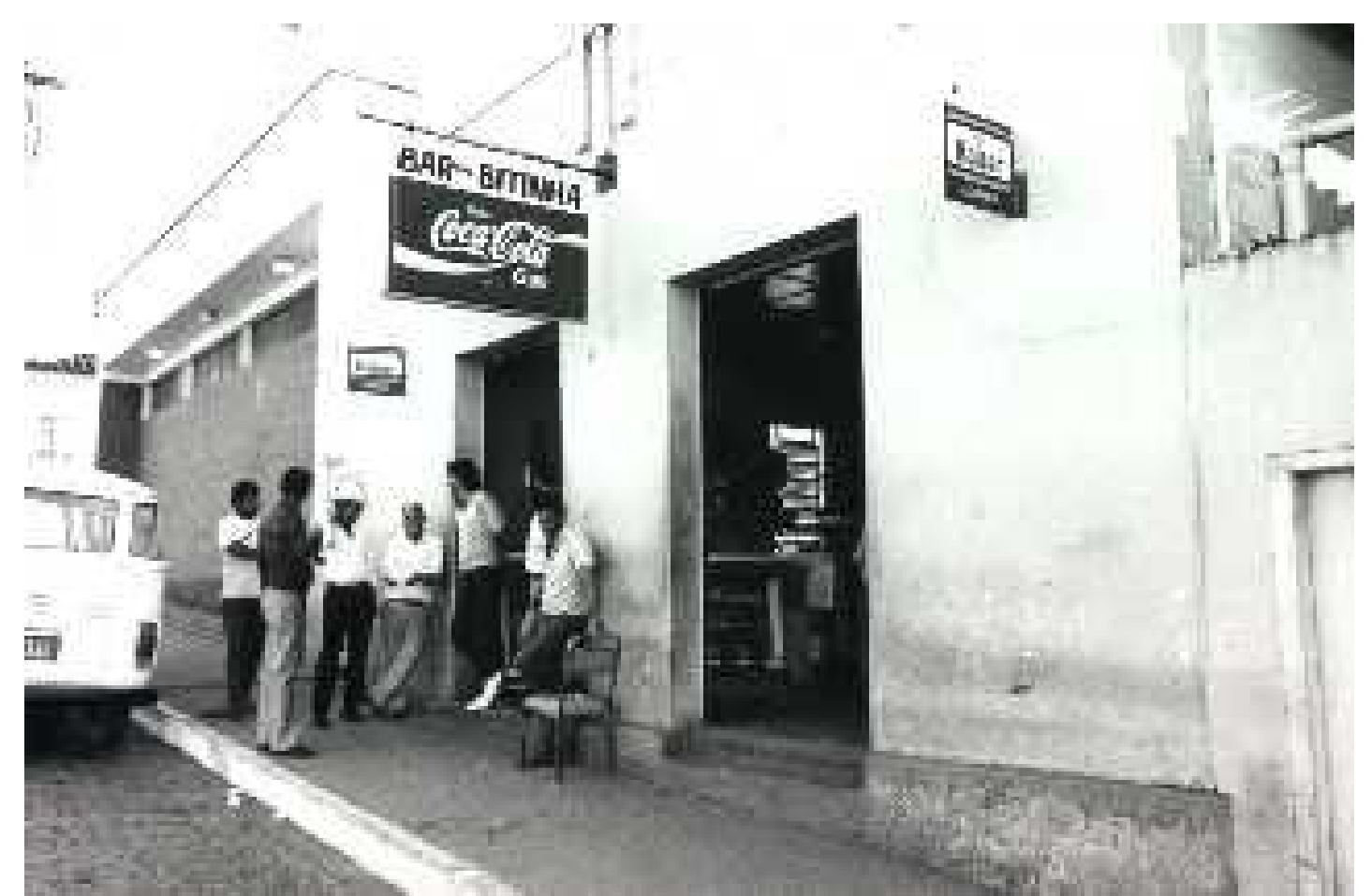

Figura. 06 - Bar do Bitinha. Imagem sem autor. Fonte: idem, (1987-88). 
O Bairro Nossa Senhora do Rosário ${ }^{18}$ - o Gravatá $^{19}$ :

O Gravatá ficava próximo ao centro, não havia nenhum armazém no bairro, e era em São Miguel que seus moradores estudavam, trabalhavam - os que não trabalhavam na roça - e assistiam as missas aos domingos na lgreja Matriz, porque na Capela do Rosário o padre Júnior só celebrava missa uma vez por mês. No Gravatá se localizavam o Cemitério do Rosário e a zona boêmia de Nova Ponte. A Rua Presidente Vargas é o caminho principal dentro do bairro. A Rua Padre Anchieta, sem calçamento, era utilizada apenas pelos moradores da Vila São Vicente e em frente a essa vila havia um grande "varal": "Sob a sombra das roupas estendidas, no final da tarde, os moradores da vila costumam se assentar para tomar a fresca e conversar" (Figura. 08). As Ruas Olímpio Góis e Pedro Paulo, também não eram pavimentadas e eram utilizadas apenas por pedestres: "Assentados em banquinhos sobre as calçadas ou nas próprias calçadas, os moradores de um lado da rua distraem-se e distraem os moradores do outro lado. Os que passam pela rua fazem o mesmo" (Figura. 09). A Rua da Saudade tinha as mesmas características. Na esquina das Ruas Presidente Vargas e Pedro Paulo havia um bar e o ateliê de costura da D. Alair Pereira Caldeira, líder da Associação dos Moradores do Bairro Nossa Senhora do Rosário, que contava: "Mesmo com esse movimento, eu gosto de morar aqui. Acostumei aqui, neste lugar. Moro ao lado do meu ateliê. Fico o dia inteiro sentada aqui, costurando. Faço compras nos armazéns da praça, no armazém do João Tarcísio. O movimento agora aqui na rua está uma loucura. Aqui passam de manhã e de tarde, uns quinze ônibus. O povo aí de cima também, virgem! Antes aqui era calmo. Os vizinhos... uns conversando com os outros. Agora, você não pode nem sair na rua. Se sair, é capaz de ouvir e ver coisas que nunca pensou, nem nunca quis ver. Aqui, bar tradicional é só esse aí em frente. O resto é só anarquia!" Este é o reflexo da zona boêmia da cidade que com a construção da barragem se expandiu da Rua das Flores até as imediações das ruas da Saudade e Pedro Paulo. (As principais referências do bairro podem ser visualizadas na Figura. 07).

\footnotetext{
${ }^{18}$ Baseado no Livro Memória do Cotidiano, elaborado pelo Projeto Memória Histórica de Nova Ponte, Escola de Arquitetura da Universidade de Minas Gerais - EA-UFMG - através do Departamento de Análise Crítica e Histórica (1987/88).

${ }^{19}$ Gravatá é uma fruta que se encontrava em abundância no bairro.
} 


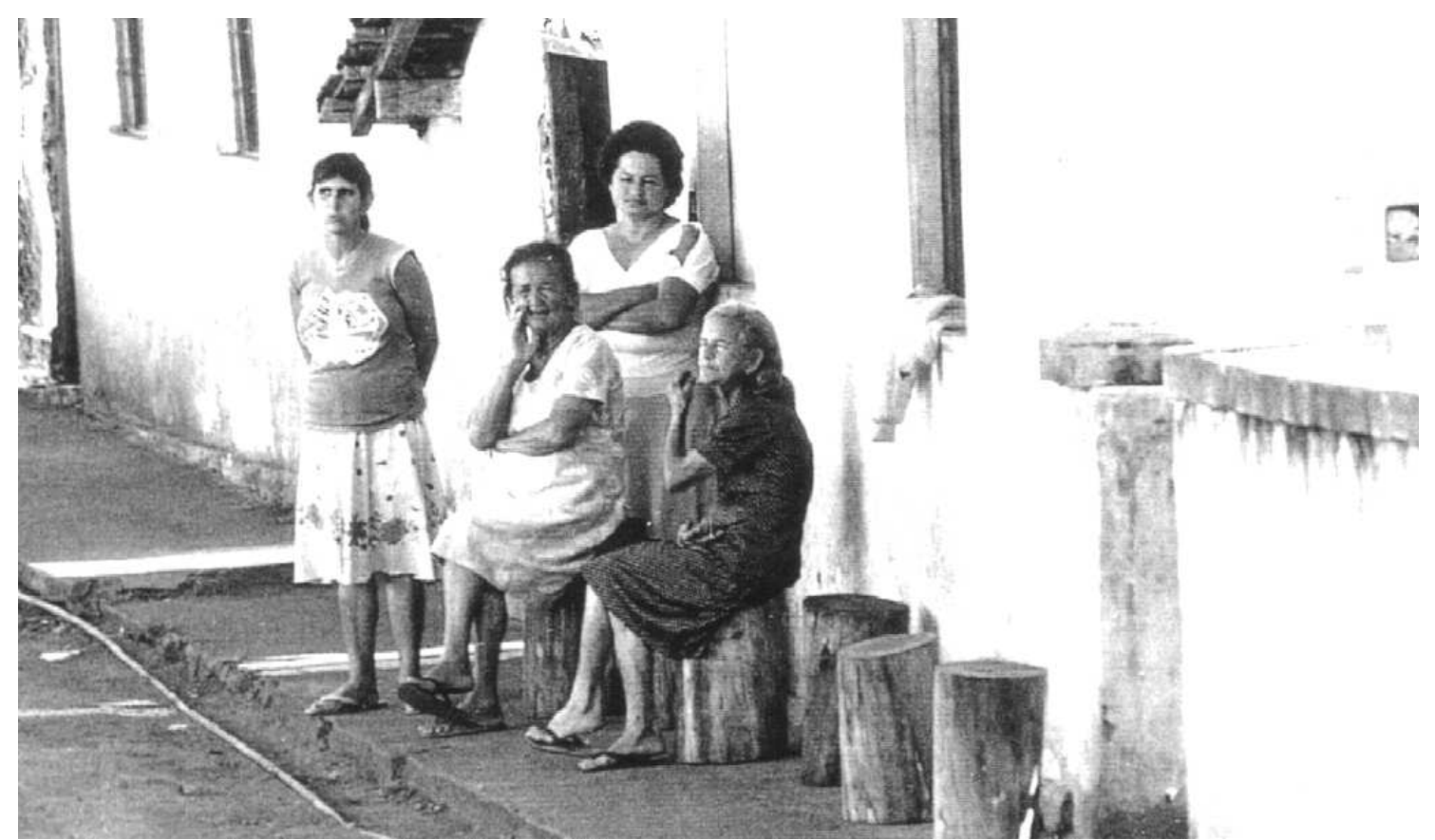

Figura. 08 - Os banquinhos. Fonte: idem (1987-88).

Figura 07. Referências do Bairro São Miguel e Rosário. (1) Farmácia São Sebastião, (2) Escola Estadual São Miguel, (3) Cerâmica São Miguel, (4) Forró, (5) Armazém Nova Ponte (Armazém do Loura), (6) Quitanda, (7) Bar do Geraldo, (8) Móveis Pena, (9) Bar do Nereston, (10) Pensão Nova Ponte, (11) Escola Estadual Magalhães Pinto, (12) Farmácia Droganova, (13) Casa São Miguel (Loja do Getúlio), (14) Posto de Gasolina Carneiro e Melo, (15) Armazém São Miguel (Armazém do Ozar), (16) Correios e Telégrafos, (17) Cartório Milton Inácio da Silva, (18) Casa Santos (Loja do Reginaldo), (19) Bar do Bitinha, (20) Casa Rural, (21) Salão Paroquial, (22) Biblioteca / Câmara Municipal, (23) Prefeitura / Telefônica, (24) Sindicato Rural, (25) Associação Atlética Novapontense - sede social, (26) Cartório Salomão Pires Maciel, (27) Praça (jardim) / Igreja São Miguel, (28) Drogaria São Pedro (Farmácia do Seu Hélio), (29) Bar e Sorveteria (Sacra Bar), (30) Casas assistenciais espíritas - O Nazareno, (31) Bar São Sebastião (Bar do Didi), (32) Armazém do Seu Irineu (do Moacir), (33) Centro Espírita Viva Deus, (34) Bar do Tázio, (35) Mercearia São Tarcísio (Venda do João Tarcísio), (36) Bar do Rodão, (37) Padaria, (38) Assembléia de Deus, (39) Bar do Tiago, (40) Costureira, (41, 42, 43) Bar, (44) Venda, (45) Oficina Mecânica, (46) Praça / Capela do Rosário, (47) Cemitério do Rosário. 


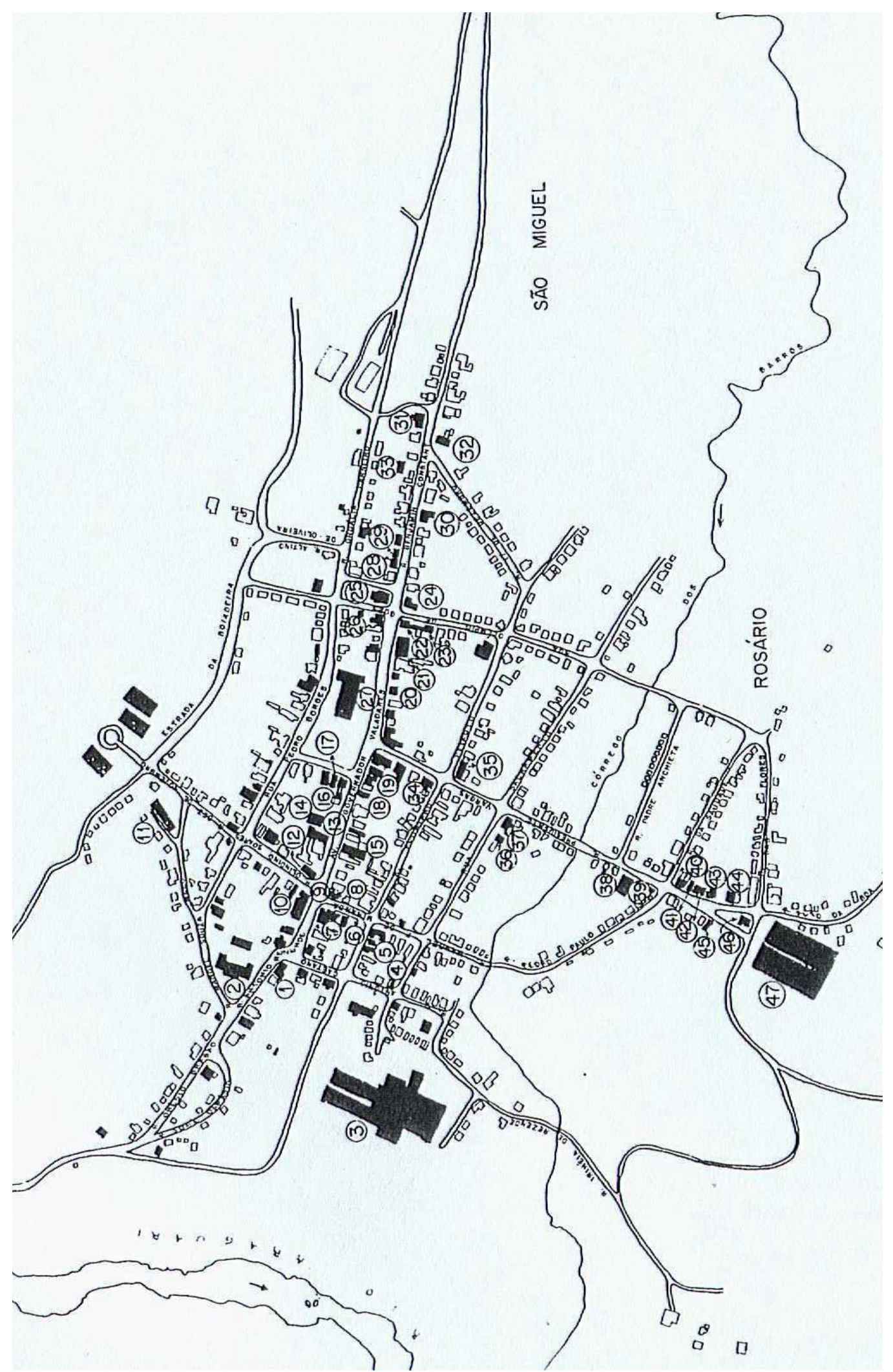

Figura. 07 - Referências dos Bairros São Miguel e Rosário. Fonte: idem (1987-88). 
O Bairro São Francisco - O Morro da Pedra ${ }^{20}$ :

O Bairro São Francisco se estendia da rodoviária até a caixa d'água da cidade e mantém relações intensas com o Bairro São Miguel: "Meu marido é que faz as compras da casa. Depois do trabalho, de tarde, ele vai lá em baixo, no Armazém Nova Ponte. Eu assisto a missa na Igreja Matriz de São Miguel. Aqui, é uma vez ou outra" (Maria das Graças Dias). No Bairro estavam a Capela de São Francisco, onde o padre rezava missa uma vez por mês, e os campos de futebol oficiais da cidade: o da Associação Atlética Nova-Pontense (Figura. 10) e o do Rosário Central. A rodoviária estava localizada no entroncamento entre as ruas Osório Inácio, Benjamin Constant e São Francisco, próximos estavam a Mercearia do Tázio, um açougue, dois bares e o Armazém do Batista. Tanto na mercearia quanto em frente ao açougue há sempre um ou mais bancos ocupados durante o dia e à noite. "Dentre todos os bairros de Nova Ponte, o Morro da Pedra parece ser o que mais está crescendo com a chegada da 'gente nova à cidade': O bairro aqui cresceu muito. Mas cresceu lá para cima. Muita gente que veio por causa da barragem veio morar aqui" (Luiz Carlos Borges). D. Henriqueta Ribeiro Duarte, observava as mudanças depois do início da construção da barragem: "O bairro aqui cresceu para cima e para os lados. Em geral o pessoal da barragem mora lá em cima. Os mais antigos aqui em baixo. Lá em cima já têm muitas casas novas, muitas ruazinhas novas". Na Rua Otávio Veiga se localizavam o Armazém do Tomé e em frente um bar, um reduto masculino: "Nas portas das casas próximas dali, as mulheres, que não freqüentam o 'boteco dos homens', conversam enquanto vigiam a casa e olham a rua". (As principais referências do bairro podem ser visualizadas na Figura. 09).

\footnotetext{
${ }^{20}$ Baseado no Livro Memória do Cotidiano, elaborado pelo Projeto Memória Histórica de Nova Ponte, Escola de Arquitetura da Universidade de Minas Gerais - EA-UFMG - através do Departamento de Análise Crítica e Histórica (1987/88).
} 
Figura 09. Referências do Bairro São Francisco. (1) Escola Estadual Jonas Pinto, (2) Trailler de Sanduíches, (3) Loja de Móveis, (4) Pontes Bar, (5) Joalheria São Sebastião, (6) - Santa Casa de Misericórdia, (7) Escritório da Andrade Gutierrez, (8) Churrascaria Mister Bull, (9) Terminal Rodoviário, (10) Mercearia do Tázio, (11) Campo de futebol Rosário Central, (12) Bar Silva, (13) Campo de Futebol - Associação Atlética Novapontense, (14) Borracharia, (15) Bar Nossa Senhora da Abadia, (16) Fazenda - máquina de beneficiar arroz, (17) Cerealista, (18) Armazém São Francisco (armazém do Pedro Tomé), (19) Bar, (20) Caixa d'água, (21) Açougue, (22) Armazém do Batista Malaquias.

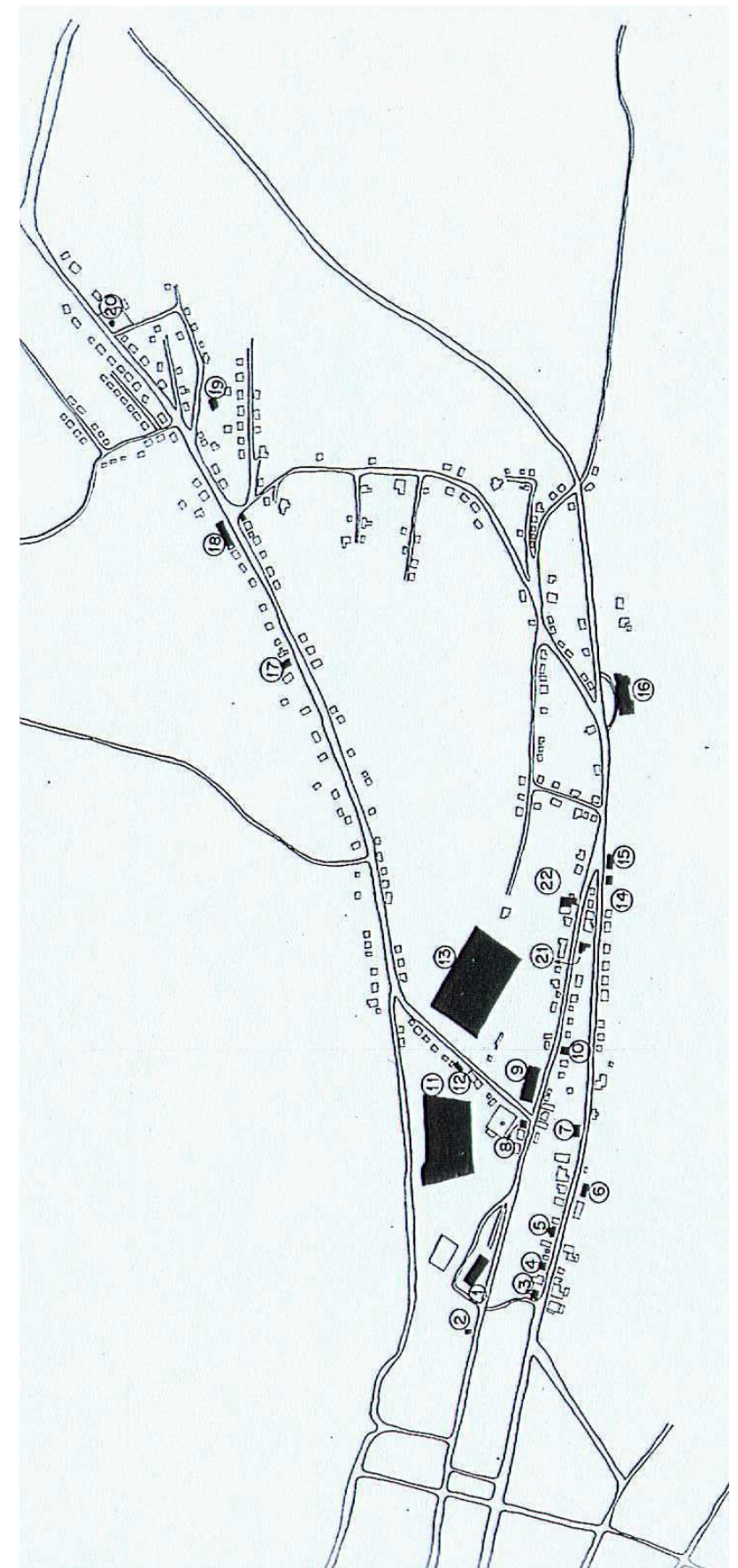

Figura. 09 - Referências do Bairro São Francisco. Fonte: idem (1987-88). 


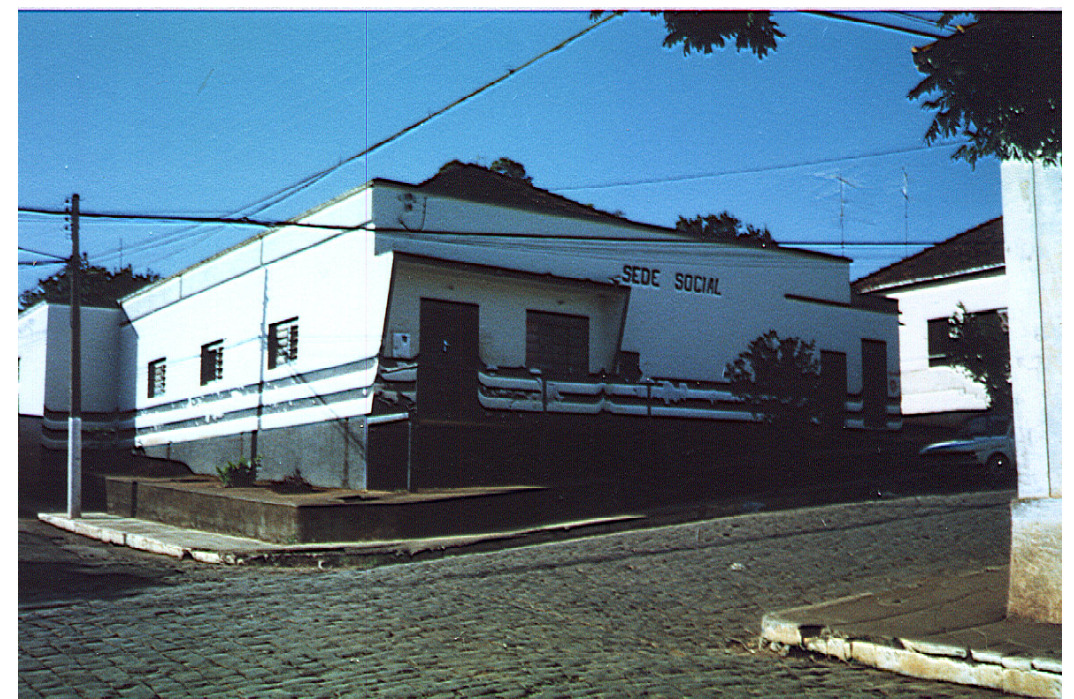

Figura. 10 - Sede Social da Associação Atlética Novapontesse. Fonte: fotografia de autoria da pesquisadora

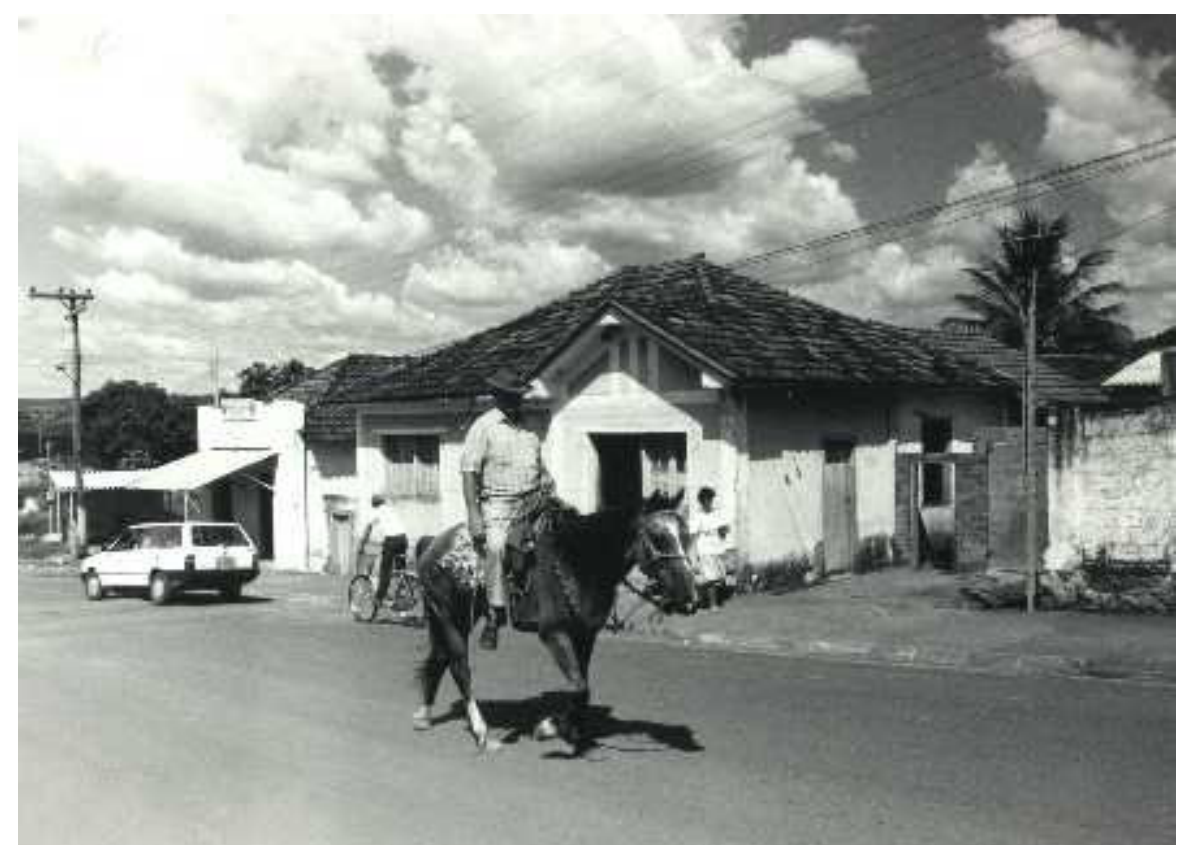

Figura. 11 - O rural e o urbano em Nova Ponte. Fonte: Memória e História de Nova Ponte (1987-88) 
O Bairro São Sebastião ${ }^{21}$ :

O Bairro de São Sebastião se localizava do outro dado do rio, suas ruas eram de terra, seus quintais grandes e muito arborizados: "Toda minha vida gostei mais de cá porque aqui é mais sossegado. De cá, é uma família só. Todo mundo é conhecido. Nós aqui não gastamos nem autoridade! Se a pessoa é necessitada, todo mundo olha" (Maria Dias Braga). "Aqui a gente tem mais liberdade. Tem mais fartura de fruta, pode criar galinha. Tem menos recursos, mas tem mais tranqüilidade... A água aqui é uma maravilha! É água de mina" (Eva das Graças Borges). No largo em frente às primeiras casas do lado esquerdo de quem sobe a Rua Florêncio Fernandes, havia dois grandes "fícus" que sombreavam o gramado da casa da D. Tereza que costumava se sentar nos degraus à sua porta e aproveitar a sombra. Em outro largo, ao lado da igreja os meninos do bairro jogavam bola, passavam da pracinha à igreja, brincavam, conversavam e ocupavam a praça (Figura. 12): "A praça é dos moleques jogarem bola e brincar" (Maria Dias Braga). Continuava D. Maria: "Sábado, na porta da igreja, a gente costuma fazer uma reuniãozinha. Sempre vem gente da roça que a gente quase não vê. Aí, depois da missa, a gente junta ali e fica batendo papo". Mas a mesma praça, à noite, era dos adultos: "Só os homens que vão para a praça de noite. Às vezes, vão as mulheres, mas aí também só elas é que vão" (Fauzi Alexandre Elias).

$\mathrm{Na}$ esquina da casa do Seu Braguinha, antigo zelador da Igreja de São Sebastião, os moradores do bairro se reuniam: "Ali perto do Seu Braguinha, ali é que o pessoal ferve. Os vizinhos vão lá para conversar, para contar casos" (Jordelina Maria Fonseca). Próximo ao Chalezinho, a casa mais antiga do bairro, e ao cartório se localizava outro largo, onde os moradores se encontravam sentados em banquinhos em frente suas casas ou recostados nas portas sempre abertas: "tomando a fresca da tarde".

O armazém do Seu Preto - o Armazém Caldeira -, era um símbolo do bairro, era bar, agência de correio, casa lotérica, armarinho e rodoviária: "... é o ponto de encontro, a casa de todos os que moram em São Sebastião". "Mais

${ }^{21}$ Baseado no Livro Memória do Cotidiano, elaborado pelo Projeto Memória Histórica de Nova Ponte, Escola de Arquitetura da Universidade de Minas Gerais - EA-UFMG - através do Departamento de Análise Crítica e Histórica (1987/88). 
do que dono do armazém, Seu Preto é o seu 'gerente e atendente de balcão'; é o seu anfitrião, o seu nome, a sua identidade". Sempre havia pessoas nos banquinhos próximos às portas do armazém, a conversa era uma só e o volume das vozes baixo e respeitoso. Quando o armazém se fechava os fregueses se sentavam na calçada ou nos degraus do depósito ao lado. "Do armazém do Seu Preto até a venda do Seu Bitinha a calçada fica cheia de gente". "Mais do que compradores, os fregueses do Seu Preto são freqüentadores de sua 'sala de estar', a qual se estende desde o seu interior até a calçada e a árvore defronte a ele". (As principais referências do bairro podem ser visualizadas na Figura. 13).

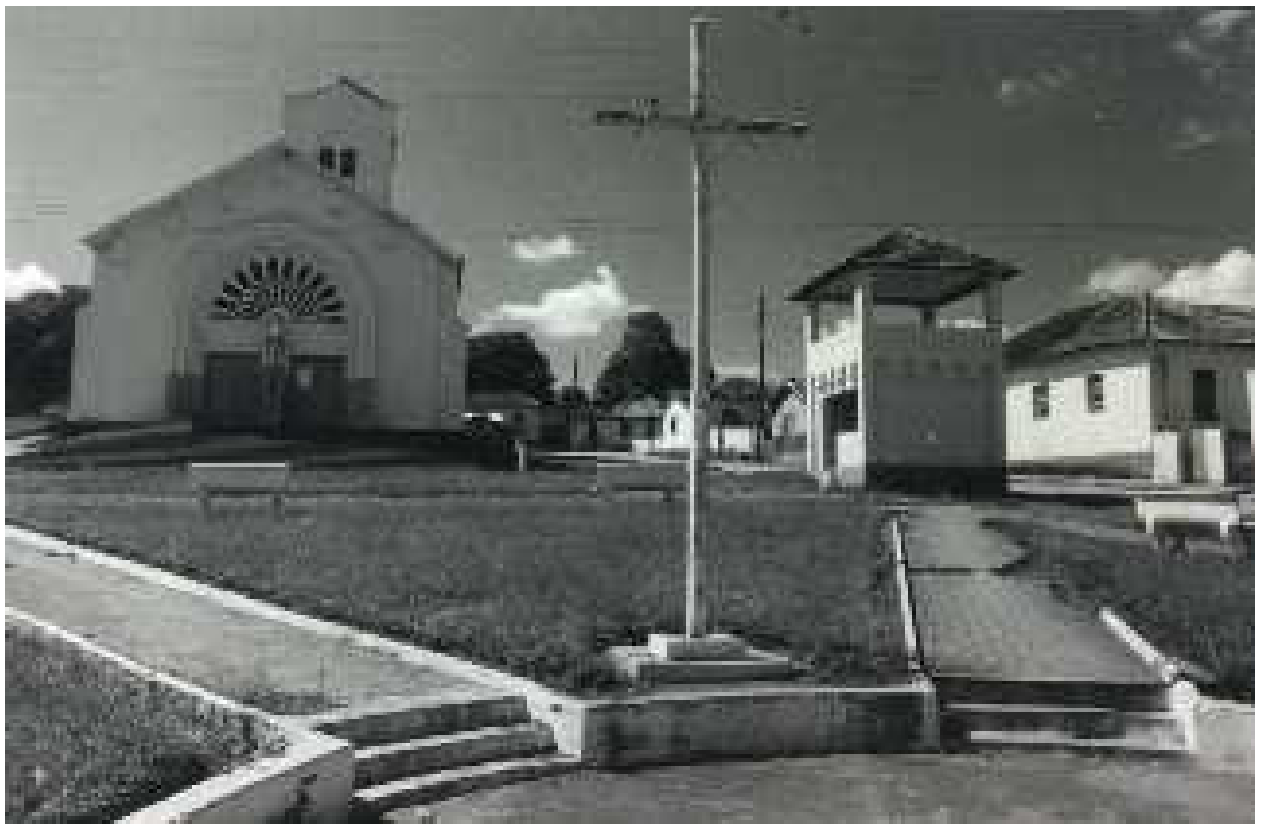

Figura. 12 - Praça e Igreja de São Sebastião na velha cidade. Fonte: Idem, (1987-88). 
Figura. 13. Referências do Bairro São Sebastião. (1) Centro Espírita / Creche O Nazareno, (2) Armazém Caldeira (Armazém do Seu Preto), (3) Depósito, (4) Boteco São Bento, (5) mobiliária Magalhães, (6) Praça / Igreja de São Sebastião, (7) Cerealista Barbosa, (8) Escola Estadual São Miguel, (9) Armazém São Sebastião (Armazém do Naldico), (10) Cerealista Pádua e Resende, (11) Cartório de Registro Civil, (12) Bar São Sebastião.

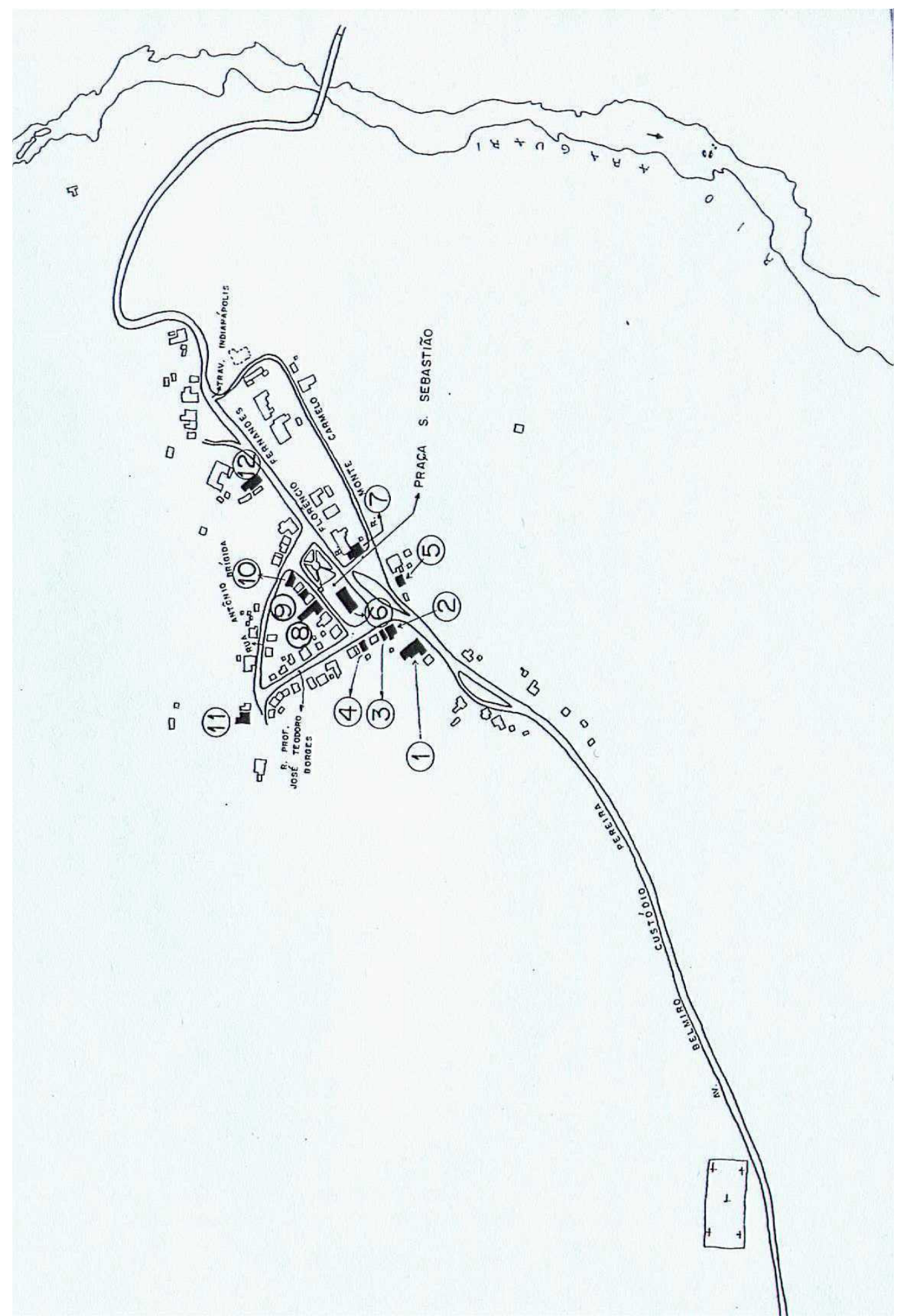

Figura. 13 - Referências do Bairro São Sebastião. Fonte: idem (1987-88) 
Bairro São João - Três Moitas ${ }^{22}$ :

No Bairro São João está o cemitério de São João e a capela de São João, onde o padre só celebrava a missa uma vez por mês. Contava o Seu Ariovaldo Naves Fernandes: "De lá do rio, o São João a gente chama da três Moitas. Chama assim porque antigamente lá tinha muita moita de capim". Os quintais do bairro eram todos espaçosos, segundo D. Marilda Cândido Cipriano: "Eu vim para cá já faz quinze anos. Aqui só aumentou casas, não abriu mais ruas, não. Meus meninos trabalham nas firmas. Eu tomo conta da casa. Tenho horta, galinha, porco - nós temos só uns poucos. Fora a reunião na igreja, só fico em casa. Saio mesmo só para fazer as coisas. Aqui não tem água. Às vezes tenho que lavar roupa lá em baixo. Sempre que fica mais gente, fica é nos armazéns à tarde". Continuava Seu Bento de Souza: "O pessoal aqui acorda às quatro horas da manhã. A vida está muito custosa. Das cinco horas em diante, eles estão chegando. Aí vão para as vendas, tomam banho, vão assistir uma novela e depois vão dormir. Esse banquinho aqui, eu que pus. O pessoal passa, bate um papo. Aqui venta diário. Na sombra aqui da árvore fica fresquinho. Eu quase não saio de casa. A gente vai de lá (São Miguel) quando é preciso um remédio, uma coisa assim, para aí (São Sebastião); a gente desce, vai de vez em quando... Aqui é assim. Eu gosto muito de morar aqui, casinha minha, lugar da gente".

Os armazéns, do Seu Waldecy e o da Nilza, eram pontos de encontro dos moradores do bairro. Em frente à escola o armazém do Waldecy era freqüentado pelos meninos de São João, e como a maioria dos donos de armazéns e cidade, o Seu Waldecy e a D. Nilza moram ao lado dos seus estabelecimentos comerciais. Em frente ao estabelecimento de D Nilza ficava a beneficiadora de arroz, onde também podia se visto um grande banco de madeira à sua porta. Em São João, São Sebastião, São Miguel e São Francisco as casas não eram muradas. Atrás da Capela de São João (Figura.14) havia um campo de futebol, era lá que acontecia a tradicional e principal festa popular de Nova Ponte - a cavalhada, segundo os antigos

\footnotetext{
${ }^{22}$ Baseado no Livro Memória do Cotidiano, elaborado pelo Projeto Memória Histórica de Nova Ponte, Escola de Arquitetura da Universidade de Minas Gerais - através do Departamento de Análise Crítica e Histórica (1987/88).
} 
moradores: "A festa mais bonita e mais famosa de Nova Ponte". Os quintais vastos do bairro, visíveis das ruas, e os estabelecimentos comerciais atraíam os olhos de quem passava: "Em São João, casa, quintal e rua se misturam; a vida social e a vida doméstica acontecem a um só tempo". (As principais referências do bairro podem ser visualizadas na Figura. 15).

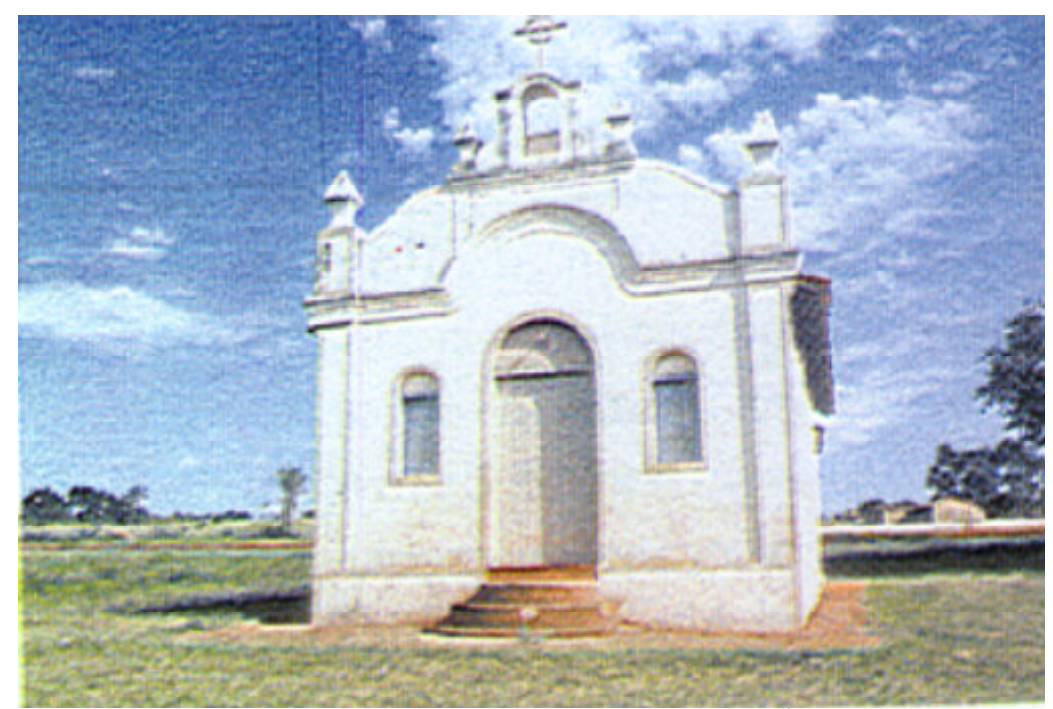

Figura. 14 - Capela de São João. Fonte: BRANDÃO (1997). 
Figura 15. Referências do Bairro São João. (1) Cemitério de São João, (2) Congregação Cristo do Brasil, (3) Cabeleireiro / manicura, (4) Armazém São João (Armazém da Nilza), (5) Armazém Rosa (Armazém do Waldecy), (6) Armarinho, (7) Beneficiadora de arroz, (8) Bar da Dona Maria Aparecida, (9) Capela de São João, (10) Grupo Escolar, (11) Campo de futebol.

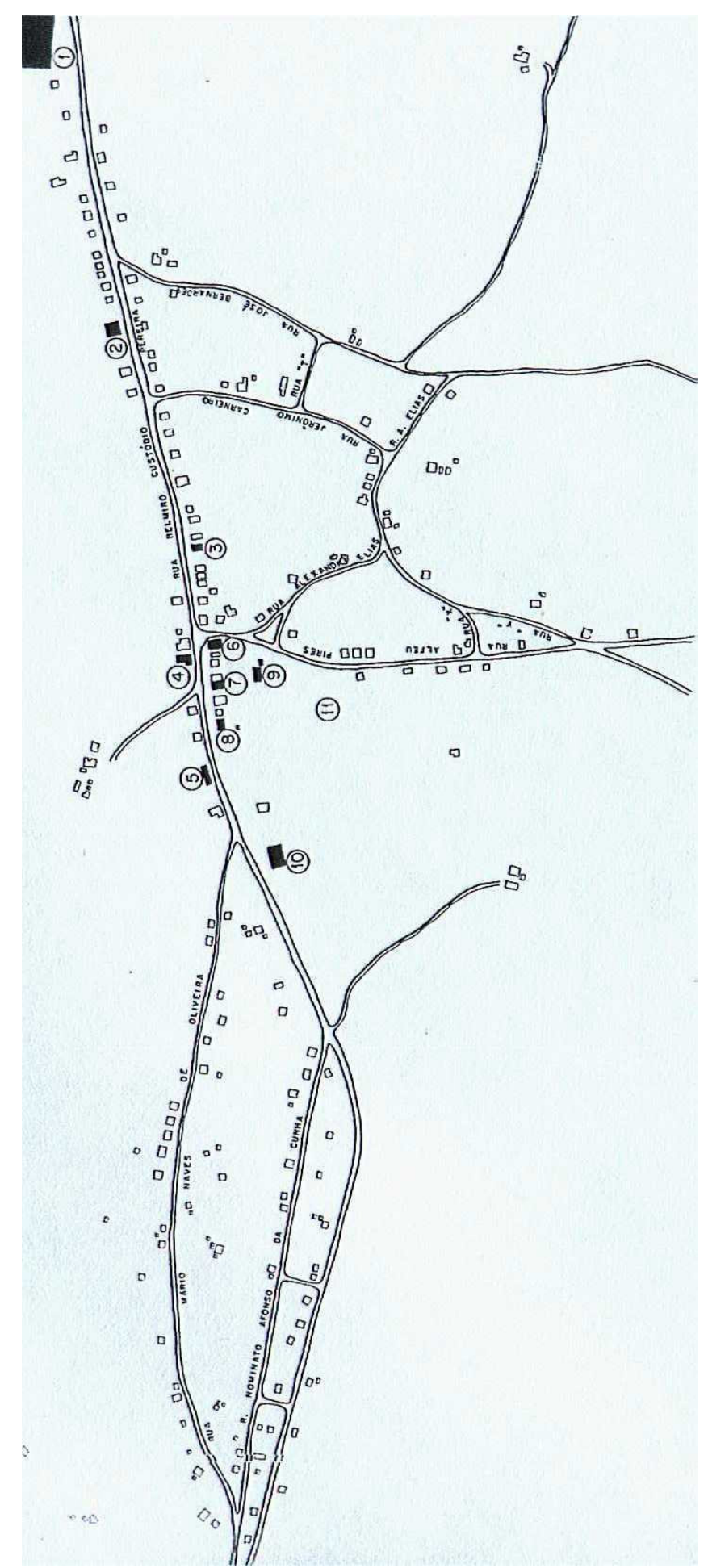

Figura. 15 - Referências do Bairro São João. Fonte: idem, (1987-88). 


\subsection{O rio}

O município era cortado pelo rio Araguari, que nasce na Serra da Canastra e desemboca no Paranaíba. Divide o município de Uberaba com o rio Claro e o rio Quebra Anzol. Era banhado pelos ribeirões e córregos: "Vertente da Mangaba", "Barro Preto", "Pindaíba", "Faneco", "Poções" e "Vertente Comprida", e possuía duas lagoas: a do Mandaguari, com 8.000 metros quadrados e a do Barro Preto.

No rio Araguari, existiam a "Cachoeira do Salto", a um quilômetro e meio da cidade velha, com os diagnosticados 30.000 H.P. de potencial hidrelétrico; no rio Claro, a "Cachoeira do Amigo", e no "Ribeirão do Brejão", a quatro Km. da cidade, a única que era explorada pela municipalidade, cuja usina fornecia luz e força à sede municipal.

As ilhas do "Salto" e a do "Jacob", no rio Araguari, também vieram a desaparecer com a construção da barragem da hidrelétrica de Nova Ponte.

No altar da antiga Igreja Matriz de São Miguel, o professor lozaino José Carneiro pintou a cena do batismo de Cristo no rio Araguari e não no rio Jordão. Na cena, atrás de Jesus e João Batista podia ser visto o "Salto". $\mathrm{Na}$ parede do Bar do Bitinha podia ser visto um pôster das águas do rio Araguari em uma enchente que atingiu a ponte. Os lugares do rio como os da cidade velha, também eram nomeados e velhos conhecidos dos moradores de Nova Ponte $^{23}$ : "Aquilo lá é minha paixão. Ele vai acabar. Nós, não. Nós, aqui, não. Nós fazemos outra casa, outra igreja. O rio, o Salto, não... não fazemos outro". Declarou Décio Inácio da Silva, morador da velha cidade de Nova Ponte.

Dona Olíria Maria de Jesus, outra moradora contava: "Tem poço Laureana, lá em baixo. Laureana era uma pescadora que morava de lá do rio. Tem o poço Rodeiro, tem esse nome porque acharam um rodeiro de carro de boi lá uma vez. Tem posso Jaú, que antigamente dava muito jaú".

${ }^{23}$ CEMIG - Companhia Energética de Minas Gerais, Memória Histórica de Nova Ponte. Belo Horizonte, 1997, pp.120. 
O morador, João Reis dos Santos, completava: "Tem o Ferrador, onde os peixes pulam que nem aqui no Salto. Tem a Lagoinha, que é onde o pessoal nada. Lá é cercado, não tem muito perigo não. Tem o Salto, não é? Tem aqui o Chorão, que só na época da enchente fica cheio. E tem o Encontro. Nós tratamos de Encontro ali onde o rio se encontra".

Assim como Seu Morse Caetano tinha um banquinho fixo na Praça São Miguel, alguns pescadores também tinham seu lugar no rio, como Sebastião Fagundes, que costumava deixar sua linha de pesca, presa a algumas pedras próximas ao poço Jaú, durante a noite e só na manhã seguinte voltava lá para buscar o peixe. Ele explicava: "Ninguém mexe porque sabe que o peixe é meu".

O Salto era um dos lugares mais caros aos moradores de Nova Ponte, Contava José Eurípedes: "Nasceu dente e caiu dente meu aqui nesse Salto. Não sei como é que vai ser sem ele".

Havia um bar no Salto, o Bar do Seu João, de onde o proprietário relatava: "Durante a semana eu abro aqui às oito e fecho ao meio-dia. Fim de semana não tem horário para fechar". Segundo D. Olímpia Soares: "Ih! A gente fazia muito piquenique na beirada do rio... Juntava uma turma, levava lanche e aproveitava". Seguia contando a moradora Lúcia Helena: "Eu ia muito lá no rio fazer piquenique na beirada do rio. Ainda faço piquenique com meus meninos. É uma diversão, sabe?".

\subsection{A Ponte}

A ponte era uma das mais fortes referências no cotidiano da velha cidade de Nova Ponte. Sobre as águas do rio Araguari, quase todos os caminhos da cidade levavam a ela, para onde se desembocavam os caminhos dos subdistritos de São Sebastião de um lado do rio e do outro lado do rio os de São Miguel. Era por onde a cidade se unia e se comunicava (Figura. $17 \mathrm{e}$ 18). Contava D Olíria: "O povo lavava roupa aí no pé da ponte. Tinha um 
batedorzão de pedra, um lugar raso. Ali, você está vendo? Aquelas mulheres acostumadas traziam as malas de roupa... mas no tempo de água limpa, na água suja não é possível. Então punham para enxugar nas pedras, nos ramos. Você passava aqui na ponte, estava cheio de roupas para todo o lado (Figura. 16). Essa ponte é antiga. Eu não tinha nascido quando fizeram ela e olha aí: a gente passa, passa... até hoje. É uma pena acabar. Vai indo... nós vamos viver num tempo em que as coisas velhas todas acabam. Olha que quando passa um carro de boi, eu mesma vou olhar. Eu, que passei a vida toda andando de carro...".

A construção desta ponte sobre o rio Araguari foi primordial para a vida da cidade e fundamental no cotidiano de sua população, mais do que a construção de um caminho reconcilia e unifica em um só corpo toda a cidade. A ponte traça uma linha entre dois pontos em uma situação única que para SIMMEL (1986), simbolizaria o movimento da vida, o lugar em que os momentos de separação e ligação se encontram, em um sentido tanto imediato como simbólico, fazendo a ligação do "finito com finito" criando uma constante relação de intercambio.

Diante de um quadro de "morte anunciada" da velha cidade, o passado e a história parecem virar o "antigo". Há um sentimento de perda que D. Olívia expressa através de sua narrativa. A moradora da velha cidade expressa uma experiência social, que se insere na discussão, sobre a tentativa de aproximação do sentido da história ao da memória social, que seria possível através desse passado narrado, ao ser revisto como produção simbólica e material de significação coletiva.

Essa narrativa provoca a discussão sobre história, memória, patrimônio e passado que deveriam formar um espaço de sentidos múltiplos, com dimensões múltiplas, de acontecimentos e coisas coletivamente significativas. ${ }^{24}$

\footnotetext{
${ }^{24}$ Segundo PAOLI (1992), o reconhecimento do direito do passado aceita os riscos da diversidade, da ambigüidade das lembranças e esquecimentos, e mesmo das deformações variadas das demandas unilaterais. Arrisca-se a encontrar as solicitações por uma memória social que venham baseadas em seu valor simbólico, mesmo que sejam locais, pequenas, quase familiares. Orienta-se pela produção de uma cultura que não repudie sua própria
} 
Assim, os depoimentos podem ser utilizados para demonstrar as formas e os usos cotidianos ligados a uma vida ancorada no lugar: "(...) eu sou onde estou, e eu estou em 'comunitas', numa comunidade, que é onde eu quero ser e estar" (TASSARA e RABINOVICH, 2001, p.234).

Estes depoimentos associam o local às pessoas no que têm em comum. O bairro, até mesmo a pequena cidade, é local de relacionamentos face-a-face, onde as pessoas têm rostos, nomes e as ruas expressam sua identidade. Há uma permeabilidade entre o espaço privado e o espaço público, onde a casa e a rua significam brincadeira, amizade e família ${ }^{25}$.

A casa e a rua, as brincadeiras e as festas, significavam amizade e propiciavam uma dimensão puramente familiar, uma rede de compadrio que poderia ser vista como um modo de extensão da casa para a rua, do privado para o público. Em uma cidade com tamanho reduzido, havia a possibilidade de se estabelecer uma conexão entre as pessoas que cuidavam dos relacionamentos, e nesse "espaço cultivado", havia uma experiência compartilhada no tempo que solidificou as redes de sociabilidade e de cumplicidade. As imagens compartilhadas, como as edificações ou os lugares, como os personagens, receberam a denominação de "históricas", não casualmente, mas como memória coletiva acumulada que referenciava as experiências de seus moradores. Havia figurações que contavam histórias dos bairros, com seus personagens ancorados em suas atividades e profissões, e da cidade, que a ela se referiam como parte de suas vidas. Uma esquina cumpria a função de ponto de encontro, definia a centralidade do bairro, havia uma identidade ancorada em um espaço, uma centralidade localizada no espaço público:

A rua é uma imagem compartilhada, pois é nela que se dá a vida social: encontros nas esquinas, conversas de vizinhos, festas de fim de ano, Natal, São João. A rua é uma extensão

historicidade, mas que possa dar-se conta dela pela participação nos valores simbólicos da cidade, como o sentimento de "fazer parte" de sua feitura múltipla.

${ }_{25}$ Para POL (1998), o espaço não tem um sentido meramente funcional, é o resumo de uma vida, das experiências públicas e íntimas. A apropriação contínua e dinâmica do espaço dá ao sujeito uma projeção no tempo e garante a estabilidade da sua própria identidade. 
da casa, e os vizinhos funcionam como uma família extensa (TASSARA e RABINOVICH, 2001, p.260).

As ruas tinham o nome do morador, onde morava aquela família, era a rua dela, como lá no Pedro Borges era a Rua do Pedro Borges. Os estabelecimentos comerciais em Nova Ponte eram, na maioria das vezes, chamados pelos nomes de seus proprietários e até mesmo, numa dupla cognominação, por seus apelidos. Assim, "ir lá no Reginaldo" era o mesmo que ir a Casa Santos e "ir ao Seu Preto", o mesmo que ir ao Armazém Caldeira.

Nos bairros podiam ser encontrados os "personagens-vizinhos", com suas conhecidas histórias, e também os "personagens-visitantes": o apanhador de lixo da Prefeitura, Seu Manoel Cecílio de Oliveira, com a vassoura de palha, Seu Manoel Messias Barbosa, o Neném Cabrito, que em substituição a seu Isabadi e sua carroça, distribuía leite caipira no seu Corcel azul, e o incógnito vendedor ambulante de galinhas, todos estes personagens, ao mesmo tempo urbanos e rurais, tinham lugar em Nova Ponte, todos pertenciam à cidade tanto quanto a cidade a eles pertencia.

Na velha cidade eram encontrados cenários como os armazéns, onde os espaços públicos eram apropriados pelos moradores durante um certo período, como os Largos de São Sebastião onde os meninos jogavam bola à sombra das árvores. Estavam presentes figuras singulares que indicavam os limites da identidade, como os territórios particulares no "jardim" - a praça de São Miguel. Os lugares que ganharam dimensão pelo encontro podiam ser identificados pelos banquinhos, presentes nos estabelecimentos comerciais, nas portas das casas, nas soleiras das portas, no limiar do público e do privado. Contavam a história da cidade e faziam parte deste cenário, a boêmia, o futebol e seus times de várzea, o clube e os bares, pareciam estar se transformando como contava D. Alair - líder da Associação de Moradores do Bairro de Nossa Senhora do Rosário - demonstrava que com o início das obras da barragem, surgia o estranho, onde nem todos seriam mais conhecidos. Na esfera social, pôde-se prever o agravamento das tensões, a medida em que uma variada tipologia de fluxos de pessoas de valores estranhos ao lugar começava a mudar a história desta população. 


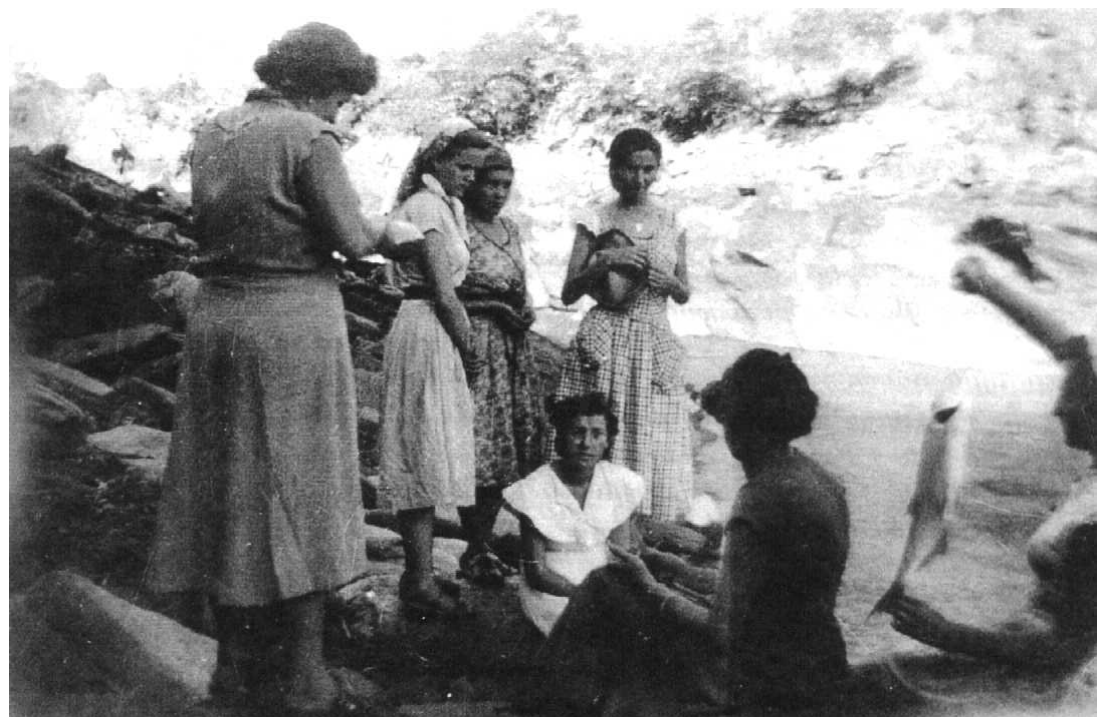

Figura. 16 - Imagem sem autor. Década de 50 - senhoras no rio. Fonte: idem, (1987-87)

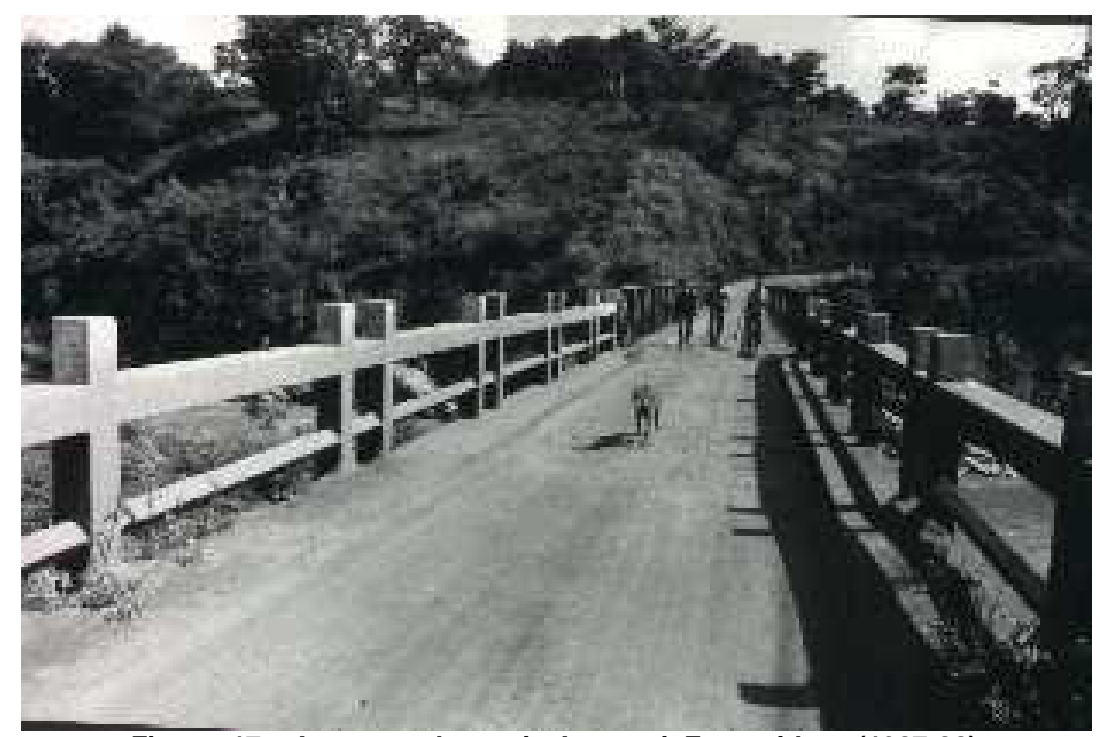

Figura. 17 - A ponte sobre o rio Araguari. Fonte: idem, (1987-88).

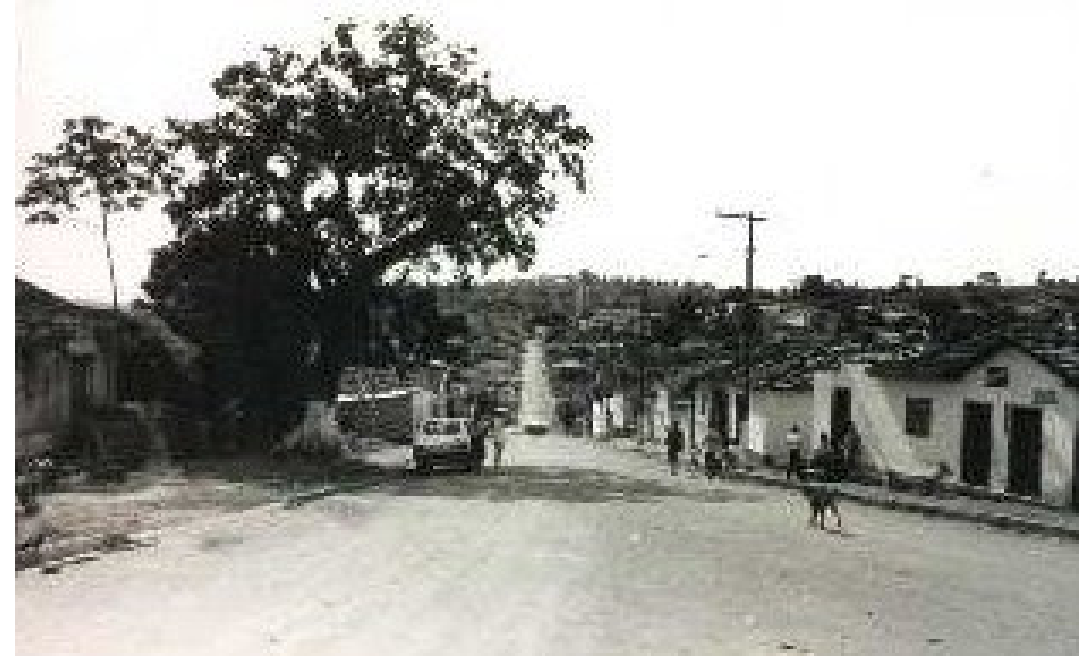

Figura. 18 - A rua que ligava os Bairros da velha cidade. Fonte: idem, (1987-88). 


\subsection{Festas Populares}

Muitos movimentos sociais recentes têm desenvolvido práticas diferenciadas, destinadas a construir sua própria memória, preservando registros e tradições plenas de significado, identidade social e cultural:

A dimensão política deste esforço reveste-se de uma importância crucial - pois todos sabemos que a memória social constitui um dos mais sólidos alicerces da dominação e do poder. A possibilidade da construção fechada de uma versão unívoca do passado repousa no poder decidir sobre o que será ou não preservado enquanto registro à disposição da posteridade (SILVA, 1991).

Correntemente as tradições populares são subjugadas a outras tantas tradições "inventadas", segundo HOBSBAWN (1990), para ocultar conflitos e produzir uma imagem harmônica da sociedade.

Desse ponto de vista as práticas populares tornam-se estratégicas. Soma-se aqui a noção de "patrimônio histórico", que deveria evocar dimensões múltiplas da cultura como imagens de um passado vivo: "acontecimentos e coisas que merecem ser preservadas porque são coletivamente significativas em sua diversidade" (PAOLI, 1991, p.25-28).

Deste ponto de vista, alguns festejos populares, os mais característicos da cidade de Nova Ponte e que foram dignos de nota: são a "Cavalhada", as brincadeiras de "Sábado da Aleluia", além das festas religiosas: a festa de São Sebastião, do Sagrado Coração de Jesus e a Folia de Reis.

A "Cavalhada" ${ }^{26}$ consiste na excursão, pelas ruas da cidade, de bandos de cavaleiros em montarias enfeitadas, trazendo toscas lanças de madeira com laranjas e outros frutos espetados e fitas multicoloridas. Depois da passeata

${ }^{26}$ A Cavalhada teve origem nos torneios medievais e foi introduzida no Brasil pelos portugueses, representa a batalha entre mouros muçulmanos e cristãos portugueses. Foi registrada pela primeira vez no Brasil em Pernambuco, 1538, pelo jesuíta Fernão Gadin. In: Théo Brandão, Memória Histórica de Nova Ponte, 1997, p 155. 
que despertava os maiores aplausos da população, os cavaleiros, em número que variava de cem a duzentos, se reuniam em terreno plano e descoberto, onde exibiam acrobacias e evoluções em conjunto. Terminavam a apresentação com um jogo denominado "cartucho": - cada cavaleiro em disparada tentava apanhar um embrulho ("cartucho") que lhe é atirado; o prêmio para quem consegue apanhar o "cartucho" é o aplauso da platéia.

As "Cavalhadas" eram realizadas todo 13 de junho, no dia de Santo Antônio. Na velha cidade, era iniciada por volta das 13 horas, no Bairro São Miguel (Figura. 20). Após o último ensaio, no campo localizado na estrada para a cidade de Monte Carmelo, os cavaleiros agrupavam-se em frente à residência do capitão e galopavam até o Bairro São Sebastião. Ali se posicionavam lado a lado, em frente à lgreja, e cumpria-se a tradicional saudação, tirando os chapéus. Após a missa, contornavam o bairro acompanhando uma procissão. Do Bairro São Sebastião seguiam para o São Miguel, onde desfilavam pelas ruas principais e se emparelhavam na praça central, que era ornamentada nas cores azul, branco e vermelho. Da praça retornavam ao campo de futebol de São João, e em fila dupla davam início às evoluções, comandado pelo capitão. Na velha cidade de Nova Ponte, o capitão, título que corresponde ao de embaixador adotado em outras regiões, pertencia há trinta anos ao Sr Amador Bernardes:

A posição dianteira é legada ao capitão e a um guia de frente, também conhecido por matinador ou mantenedor. Outros dois cavaleiros posicionam-se ao meio, controlando a fila até o final. Estes recebem o título de guias de meio. Os dois últimos são conhecidos por cobridores ou culatra. Um cavaleiro vestido de palhaço tem a incumbência de fazer graça em todas as evoluções, enquanto o alferes carrega a bandeira, cujo motivo principal é o santo. A primeira evolução é conhecida por" saudação ". Os cavaleiros dão voltas na pista ao som de uma banda de música. Em seguida desfilam emparelhados carregando crianças nos braços. Normalmente as famílias pedem graças ao santo e" pagam promessas “, concedendo seus filhos aos cavaleiros que se incumbem de dar a volta no campo. Finda a" Saudação "e o" Voto das Crianças “, inicia-se 
o torneio propriamente dito. As evoluções seguintes exigem destreza e maestria dos participantes. Posicionados nos extremos do campo, os dois grupos - um branco e azul".(normalmente representando os portugueses); o outro branco e vermelho (representando os mouros) - iniciam as corridas de parelhas, denominadas na região: "X dobrado", "Limão", "quatro guias", "Cartucho", "Esteirão" e "Despedida". O torneio termina com a "Despedida", quando os integrantes agrupam-se intercalados (branco-azul e branco-vermelho) e, aos pares desfilam acenando seus lenços ao público, em sinal de gratidão (BRANDÃO, 1997, p.156).

As brincadeiras de "Sábado de Aleluia" caracterizam-se pela passeata, na noite de Sexta-feira Santa madrugada adentro, quando a população, levando um títere de pano representando Judas Escariotes, subtrai das residências vários objetos que são colocados em casa de terceiros ou que só aparecem na noite de Sábado, na hora da queima do Judas, queima solene com discursos, testamentos, fogos, etc.

A Festa de São Sebastião realiza-se em 10 dias, com novenas, procissões, leilões, bingos, danças, shows. Os festeiros, escolhidos a cada ano pelos do ano anterior, são responsáveis pela programação das festividades. A programação das atividades depende das doações dos moradores da cidade, feitas através de prendas ou dinheiro. $O$ encerramento da festa acontece no seu décimo dia. Logo nas primeiras horas, tem-se a "alvorada", uma salva de fogos de artifício. Ao meio dia, outra rajada de foguetes. Às duas horas é realizada a missa e, em seguida, forma-se a procissão. Depois se tem o nome dos próximos festeiros e, então, é aguardar a Festa de São Sebastião do ano seguinte.

A Festa do Sagrado Coração de Jesus (Corpus Christi) acontece sempre em junho. Neste dia, os moradores da cidade ornamentam as ruas, confeccionando "tapetes" de flores, serragem, folhas, cal, etc. Os postes são enfeitados com flores, as famílias mais tradicionais colocam panos coloridos e 
bordados nas janelas. No dia da festa, na praça, os postes de luz recebem flores e fitas coloridas. $\mathrm{Na}$ igreja, realiza-se uma missa e, em seguida, a procissão sai, passando pelas ruas ornamentadas... Após a procissão, na porta da igreja acontece o leilão, e depois são escolhidos os festeiros para as festas do ano seguinte.

A Folia de Reis acontece entre os dias 25 de dezembro e 6 de janeiro, para o pagamento de promessa feita por devoto aos Santos Reis. Tendo alcançado a graça, o devedor do voto ou a pessoa escolhida por ele organiza a saída dos foliões para percorrer a cidade durante o tempo prometido, pedindo esmolas e auxílio para os pobres em várias casas e fazendas. Aqueles moradores que os auxiliam são convidados para a Festa dos Reis Magos no último dia da procissão, realizada na casa daquele que teve seu pedido atendido. Uma banda com cavaquinho, violão, bumbo, pandeiro e sanfona toca músicas que os foliões vão cantando pela cidade. Na frente do grupo vai a bandeira dos Santos Reis, estampada com figuras do Menino Jesus na manjedoura e dos três Reis Magos, enfeitados com notas de dinheiro. Ao seu lado, o Capitão da Companhia dos Reis orienta o canto e a folia (BRANDÃO, 1997, p.156).

Até hoje, em Nova Ponte, os foliões cantam quando chegam às casas para pedir o auxílio, sendo bem recebidos. Do grupo de Folia participam palhaços que são mascarados e fantasiados de homem ou de mulher e, através de brincadeiras procuram arrecadar mais dinheiro. O encerramento da Festa acontece na casa do pagador da promessa, com a reza de terço e a entoação de cantigas, festança, "comes e bebes" e muito forró. A bandeira é colocada em um pequeno altar na casa.

As festas religiosas que aconteciam na velha cidade de Nova Ponte, ainda são realizadas anualmente na nova cidade, mas nos relatam os moradores 27 : "As festas da igreja eram melhores que as de hoje. Havia muito movimento, com banda de música - a banda do Antônio Clariano, a de São

${ }^{27}$ Em depoimento para o projeto "Memória Histórica de Nova Ponte", 1997. 
Miguel" (Calimério Ferreira, morador); "O povo vinha todo da roça, vinha fazendeiros, os trabalhadores da roça mesmo, amarravam os cavalos... Na época, armavam barraquinhas nas praças" (Ubaldo Damásio); "As festas da igreja eram muito animadas, tanta gente! Tinha leilão tabuleiros de salgados, de doces. Cada um fazia em casa" (Olímpia Soares).

A Cavalhada acontece, no mesmo dia 13 de junho, na nova cidade de Nova Ponte e continua sendo um dos eventos mais importantes para a cidade, apenas o número dos cavaleiros participantes diminuiu pela metade, passando de 100 a 200 para 50 a 100 cavaleiros. Já o público, em grande número, prestigia a festa que tem seu reconhecimento regional (Figura. 21).

O carnaval, que é realizado na praia artificial formada pelas águas da barragem da hidrelétrica, tem ampla divulgação na mídia regional: "O carnaval de Nova Ponte, hoje, já é conhecido nacionalmente" - arriscam seus moradores. $O$ evento atrai um grande número de turistas e torna realidade 0 aproveitamento econômico do lago formado pela barragem, trazendo divisas para o município (Figura. 19).

Outros eventos, como festivais de música popular, estão sendo implementados pela municipalidade no mesmo local, e conseguindo atrair uma grande quantidade de turistas ocasionais para a cidade.

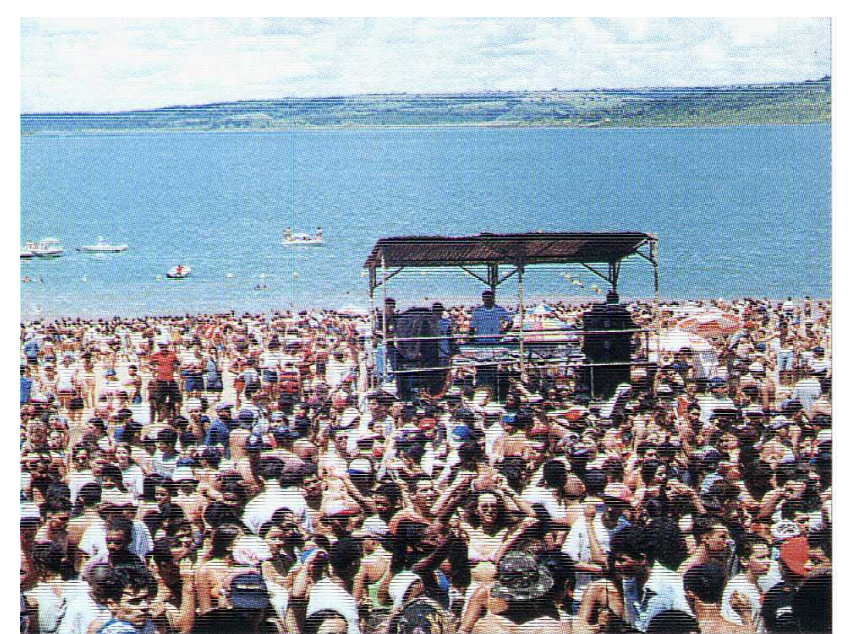

Figura. 19 - O Carnaval na praia artificial da nova cidade. Fonte: Prefeitura Municipal de Nova Ponte (2000). 


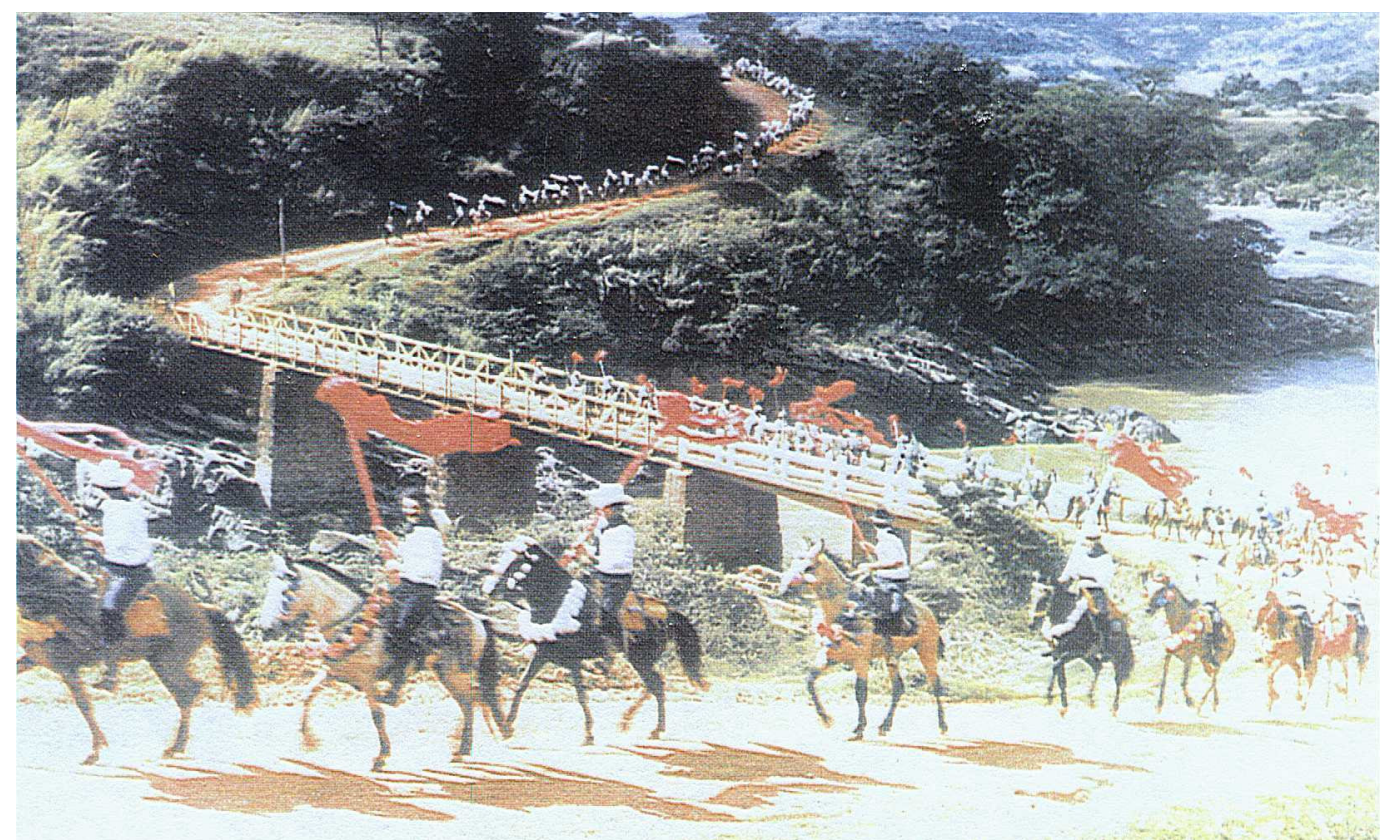

Figura. 20 - Imagem da ponte, do rio e a Cavalhada na velha cidade. Fonte: BRANDÂO (1997).

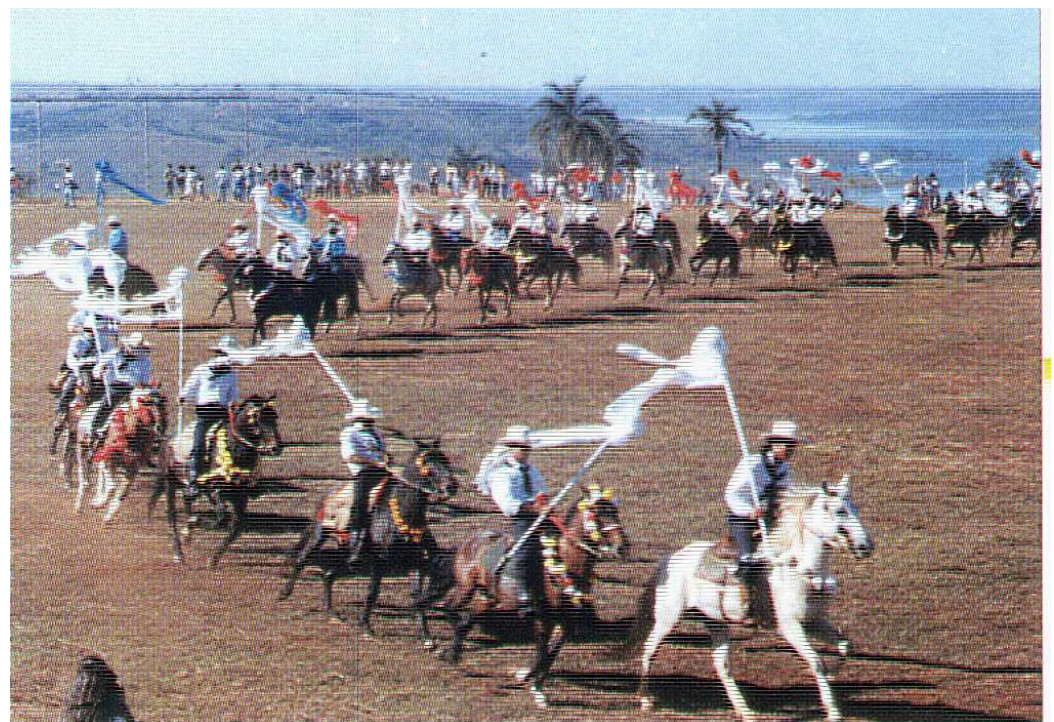

Figura. 21 - A Cavalhada na cidade nova. Fonte: Prefeitura Municipal de Nova Ponte (2000).

Foi através do conjunto dos depoimentos relacionados ao território, que se tornou possível delimitar a fronteira entre os espaços públicos e privados em função de uma história coletiva, de um enraizamento e do apego dos moradores ao velho lugar e suas redes de sociabilidade: $O$ bairro de São Sebastião era o que mais tinha árvores e gramados públicos, onde as "salas de estar" ultrapassavam as calçadas, os estabelecimentos comerciais e a praça. Todo o bairro, imutável por muitos anos, foi um salão do encontro. Todo o bairro era um espaço conhecido e reconhecido, um espaço próprio daqueles 
que nele viveram e conviveram diariamente. O rio Araguari, mais do que a praça era a paisagem de toda a vida da cidade de Nova Ponte. Os lugares do rio, como os da cidade, também eram nomeados, também eram velhos conhecidos dos moradores da antiga cidade. Sobre as águas violentas do rio, a ponte era para onde levavam quase todos os caminhos da cidade velha, onde desembocavam os caminhos dos subdistritos de São Sebastião e São Miguel e por onde esses caminhos se comunicavam. A ponte que desapareceu, foi uma das mais fortes referências no cotidiano na cidade, uma das mais fundamentais referências da sua história. Na nova cidade a lgreja de São Sebastião, por decisão da comunidade, seria uma réplica do antigo templo, e a Matriz de São Miguel, apenas guardaria semelhanças com a da antiga cidade. A Fazenda Cachoeira e o Chalezinho foram as edificações consideradas mais significativas para a população local, sendo transplantadas para a nova cidade. A busca por reconstituir e preservar esses monumentos do patrimônio da cidade, como forma de comunicação social enquanto símbolo, seria uma tentativa de resgatar algo de sua memória coletiva.

O Chalezinho era a edificação mais antiga não só do bairro São Sebastião, mas segundo BRANDÃO (1997), da cidade de Nova Ponte, datada do terceiro quartel do século XIX, de uso exclusivamente residencial, tinha como características além de sua beleza, o caráter nobre dos eventos que ali se realizavam quando ocupado pela família de Teófilo Perfeito. A própria edificação refletia a condição de seus primeiros moradores. O mirante existente na fachada frontal, protegido por um gradil de ferro trabalhado, era utilizado como local de leitura. Dali também se chamava, ao toque do berrante, os trabalhadores da lavoura de café. A importância do Chalé era realçada por uma escada de oito degraus em semicírculo, construída com pedras, que levava até o pátio ajardinado de entrada, onde se localizavam duas palmeiras imperiais. A estrutura da casa é formada por peças de madeira, totalmente independentes. O telhado é constituído por três águas com telhas de barro do tipo capa e bicas artesanais, e com o madeiramento apoiado sobre frechais que transmitem as cargas para os esteios também de madeira. Esses esteios recebem as cargas do forro, das paredes e do piso. Destaca-se a ausência de tesouras que foram substituídos por caibros autoportantes superestruturados. O forro de tábua 
corrida é sustentado por barrotes e a casa é toda forrada, exceto em dois quartos e no salão. (Figuras. $22-26$ ).

Tudo indica que todas as paredes eram originalmente de pau-a-pique. Eram construídas de uma série de paus roliços, cujos extremos em cunha se apoiavam em travessões cavados em pontos idôneos no alto e em baixo.As varas eram trançadas em esquadro aos dois lados destes "pau-a-pique", presos aos pontaletes e travessões. Enchia-se de barro bem amassado os espaços entre as varas, cuja função era justamente sustentá-lo. Depois de seca, a parede recebia reboco e a caiação. Com o tempo as paredes originais danificadas foram sendo substituídas por tijolos, assentados em argamassa de barro. Todas as paredes são revestidas de terra e cal ou de terra e estrume de gado "vacum". ${ }^{28}$ (Figura. 27).

O piso de tábuas largas, corridas sobre barrotes, formava sobre a metade da casa um porão habitável, conforme apresenta a planta de levantamento arquitetônico. O porão tem o piso pavimentado com grandes patacões de pedra e paredes também de pedra que não executam a função de sustentação dos barrotes do piso nem as paredes superiores da casa, sendo sustentados por vigas de grande seção que transmitem as cargas para os pilares de madeira. De uma maneira geral, o Chalezinho se assemelha às casas mineiras que, segundo LIMA (1978), teriam apenas uma aparente fragilidade graças às dimensões e à ótima qualidade das madeiras empregadas, erguidas com toras de madeira toscamente lavradas a machado, formando o arcabouço do edifício, ao qual se prendia a armação das ombreiras e vergas de aberturas marcadas. À parte dos esteios, mergulhados na terra, era crestada a fogo até que uma camada de carvão se formasse em seu torno. Fixavam-se barrotes, escadas, divisões internas, tudo de madeira de vulto. No corpo original da casa não havia instalações hidráulicas. A cozinha e o banheiro estariam em um puxado construído posteriormente.

${ }^{28}$ BRANDÃO (1997 p.49). 


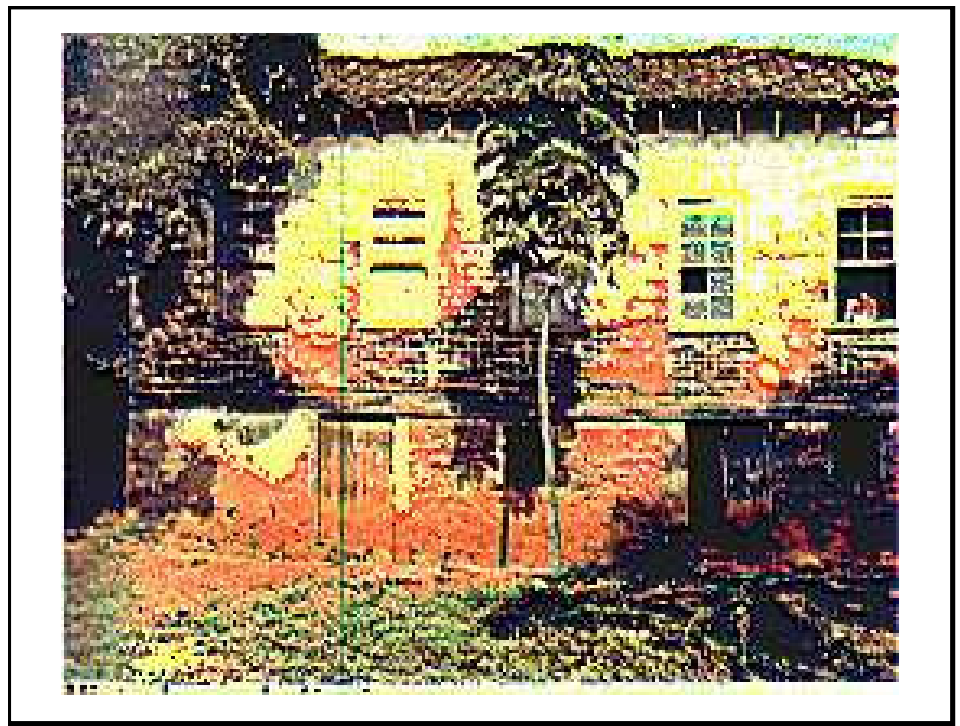

Figura. 22 - Fachada do Chalezinho na velha cidade. Fonte: Memória e História de Nova Ponte (1987-88).

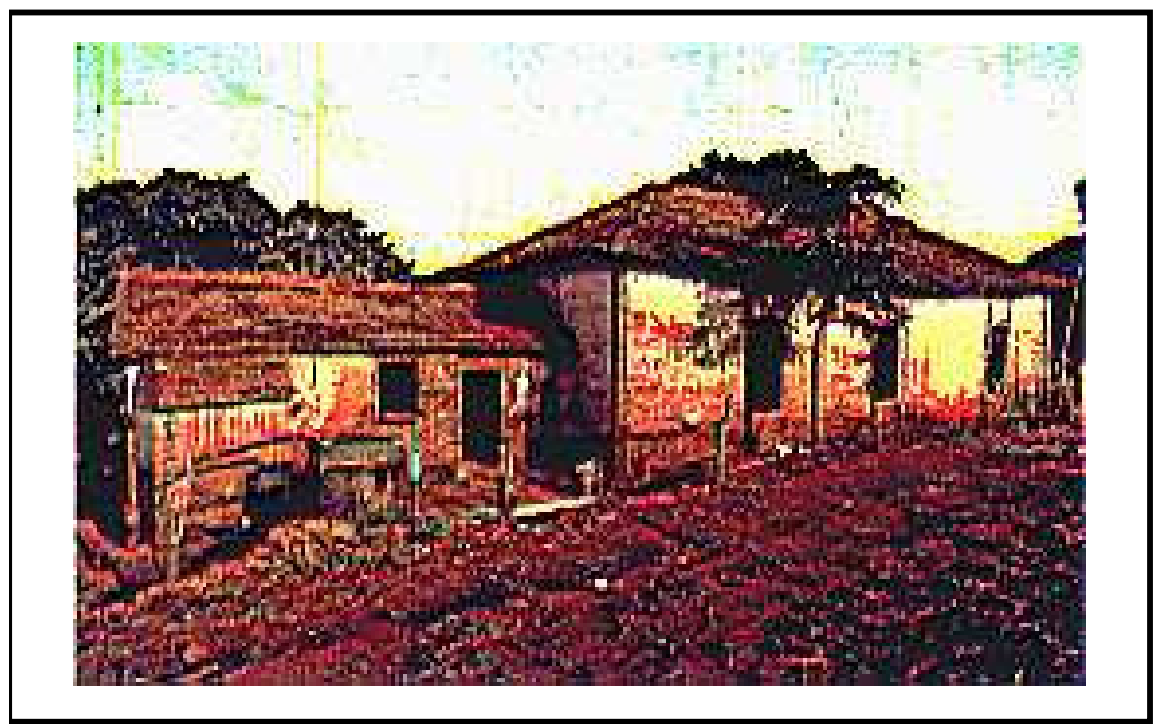

Figura. 23 - Fachada do chalezinho. Fonte: idem, (1987-88).

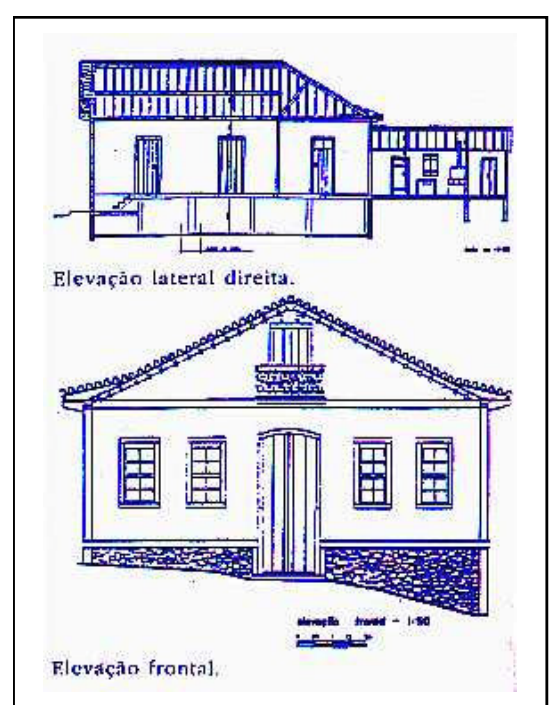

Figura. 24 - Elevações do Chalezinho. Fonte: idem, (1987-88). 


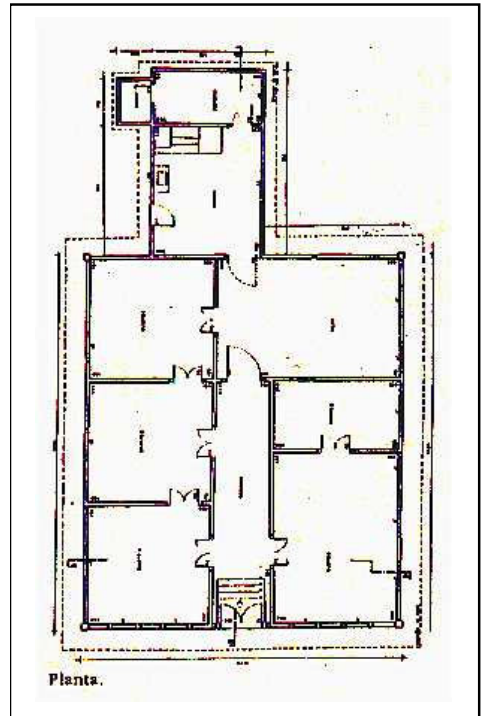

Figura. 25 - Planta baixa do Chalezinho. Fonte: idem. (1987-88).

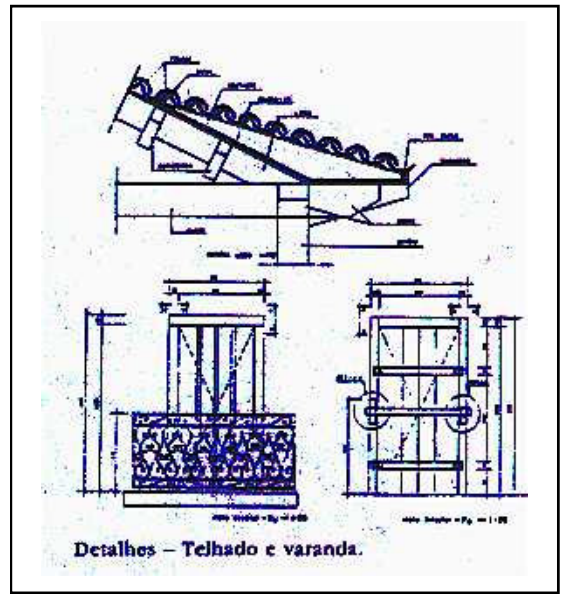

Figura 26 - Detalhamentos do Chalezinho. Fonte: idem. (1987-88).

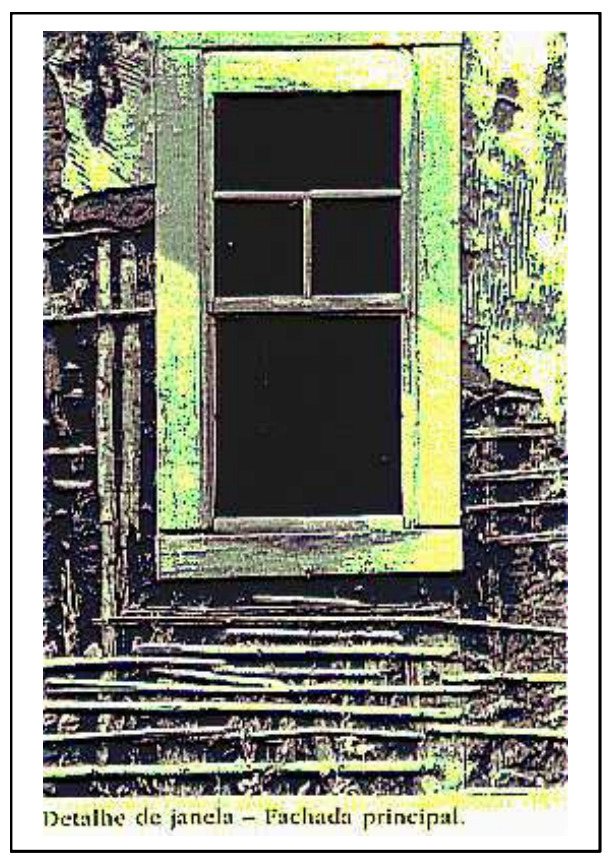

Figura 27 - Detalhe de vedação do Chalezinho. Fonte: idem. (1987-88). 
Na Fazenda da Cachoeira, antigo Engenho da Serra, onde se fabricava açúcar, cultivava-se arroz, milho, feijão e fumo, realizavam-se muitos bailes, especialmente na época da colheita. Originalmente construída em pau-a-pique, tinha uma pintura na parede da sala de jantar representando a Santa Ceia. Sua estrutura era independente e cobertura era tradicional de quatro águas. As telhas antigas e artesanais de capa e bica, sem forro, como na maioria das fazendas coloniais mineiras. Os pisos eram de tábuas largas de peroba do campo, apoiadas sobre barrotes. No porão não havia ocorrência de baldrames de fechamento, sendo que a frente da casa era de pedra com função de arrimo. A escada de entrada originalmente era de pedra tapiocanga da beira do rio, tendo sido substituída em 1940. A construção da sede desta fazenda data do último quartel do século XIX e seu uso foi exclusivamente residencial. (Figuras. $28-32$ ).

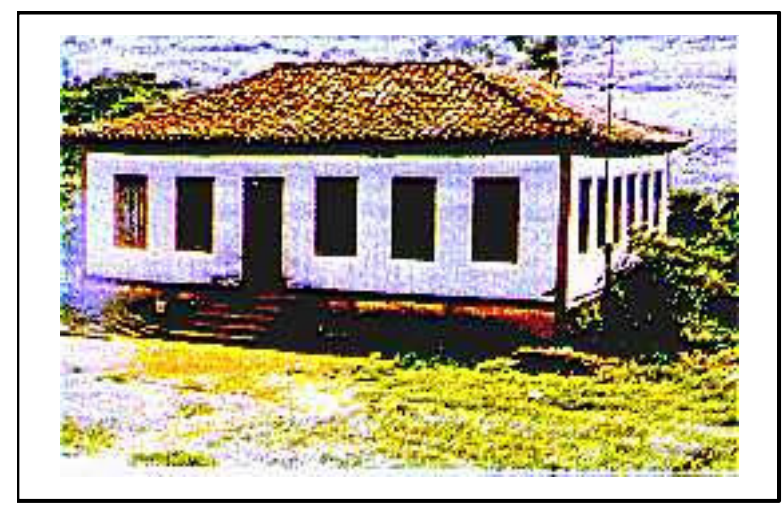

Figura. 28 - Fachada da Fazenda Cachoeira. Fonte: idem. (1987-88).

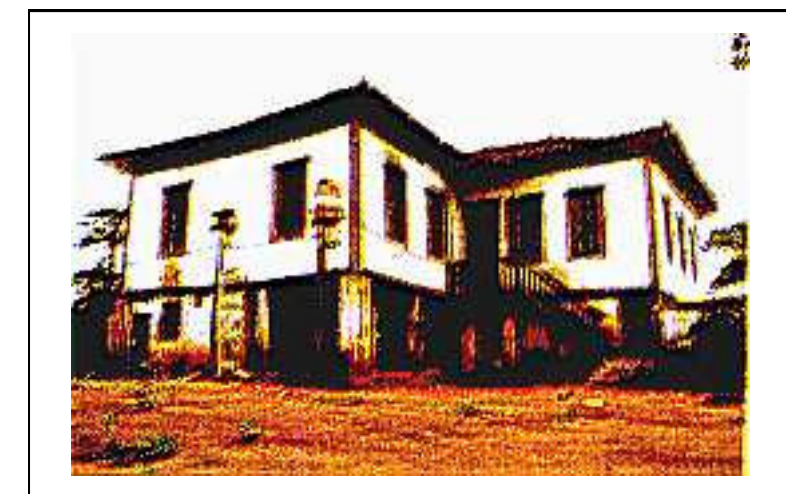

Figura. 29 - Fachada da Fazenda Cachoeira. Fonte: idem. (1987-88). 


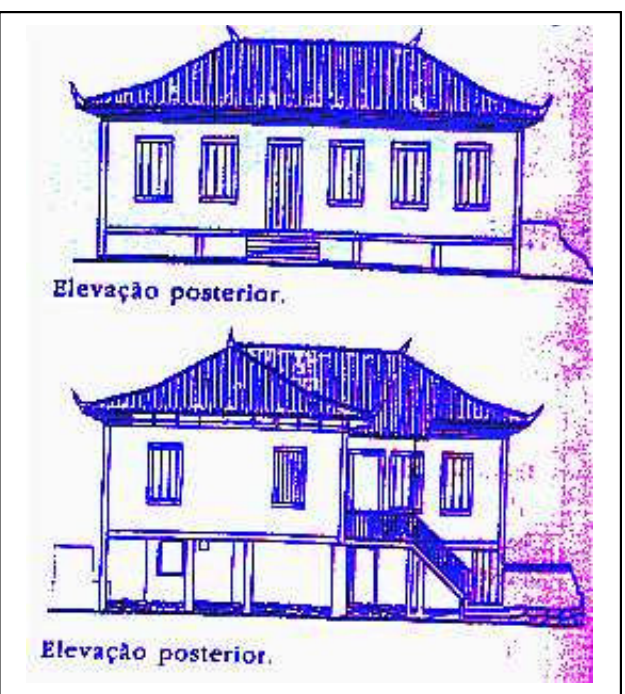

Figura. 30 - Elevação Fazenda Cachoeira. Fonte: Idem. (1987-88).

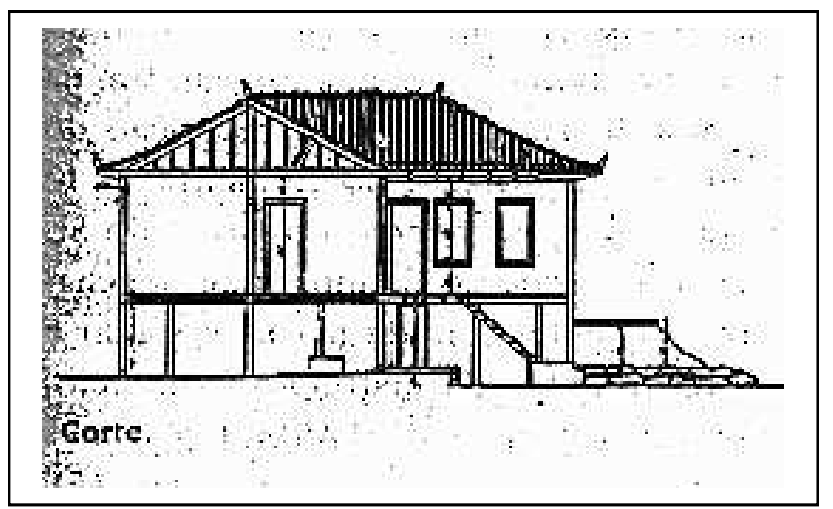

Figura. 31 - Elevação da Fazenda Cachoeira. Fonte: idem. (1987-88).

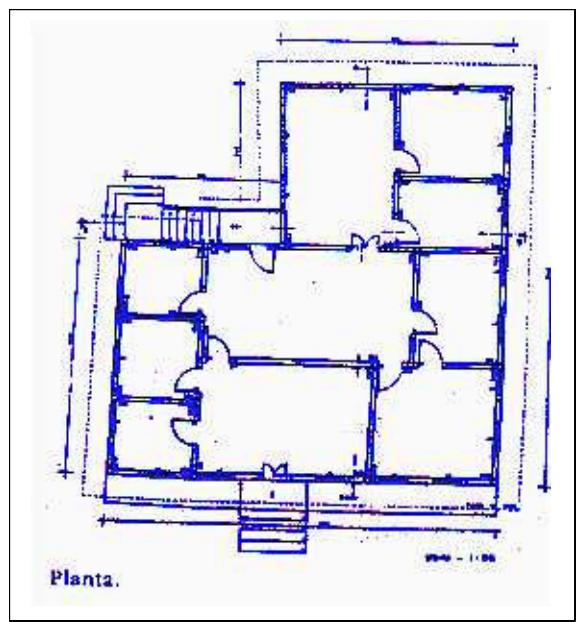

Figura. 32 - Planta da Fazenda Cachoeira. Fonte: idem. (1987-88). 
O Chalezinho e a Fazenda da Cachoeira foram considerados eixos de preservação da memória local, através dos levantamentos da CEMIG e UFMG, e relocados na íntegra para a nova cidade de Nova Ponte. Segundo BRANDÃO (1997), o objetivo do levantamento das edificações ultrapassa o aspecto meramente físico das construções e procura resgatar também a sua importância na memória e no imaginário da cidade.

A questão é a noção de "patrimônio histórico" que deveria, segundo PAOLI (p.26,1992), evocar dimensões múltiplas da cultura, como imagens de um passado vivo: "acontecimentos e coisas que merecem ser preservadas porque são coletivamente significativas em sua diversidade".

Em Nova Ponte, na tentativa de preservar um pouco de seu passado, foram transferidas duas antigas edificações para a nova cidade: o Chalezinho e a Fazenda Cachoeira, que hoje abrigam o Arquivo Público de Nova Ponte e o Museu Rural. Este processo abre um debate em torno das concepções de "preservação" e de "construção do passado". ${ }^{29}$ Por um lado, o passado e seu registro diante da "produção do novo" teriam outro significado, isto é de acordo com PAOLI (1992), passado e história pareciam virar o "antigo"; nestes casos a preservação seguira apenas os critérios estéticos ou ditados pelo mercado que a história, nestes termos, seria concebida como um processo acabado e fechado aos significados sociais. Por outro lado, a identidade como o "antigo" que parece estar apenas no sentimento de perda: "o critério de preservação dos documentos, objetos e monumentos, constitui uma forma de nostalgia de algo que não existe mais. Novamente a história se fechou" (PAOLI, 1992, p.2528). ${ }^{30}$

Quando tais processos ocorrem, a política de preservação e a construção da historiografia remetem à história "dos vencedores", isto é a história "oficial", que esconde e silencia outras narrativas - experiências que são silenciadas e suprimidas da população e afasta o sentido da história do da

\footnotetext{
${ }^{29}$ PAOLI, (1992, p.25-28).

30 "Parece claro que uma sociedade onde se pensa que tudo pode ser destruído ou conservado, tem uma noção de história - passado e presente - completamente abstrata. Nestas condições ela não é uma forma de conhecimento, não é um chão de enraizamento, não se produz como referência com a qual se possa refletir sobre a experiência social" (idem. 1992, p.25-28).
} 
memória social.

As duas edificações que foram preservadas tiveram como o critério de escolha a data da construção, por representarem um exemplar da área urbana e um exemplar da área rural de Nova Ponte. Segundo D. Maria Aparecida Palmieri: ${ }^{31}$ "O pessoal não considerava casa velha, tanto que o prefeito que substituiu a Gil Carneiro, que era o Milton Pereira, não se moveu, não fez nada para preservar a casa onde ele nasceu, era para ele resolver, a fazenda que era do pai dele, onde ele viveu o tempo todo... ele não fez questão." Sobre o uso das edificações na nova cidade: "Mas hoje, a casa que é hoje o Museu e a do Chalezinho, são mais usadas, principalmente o Chalezinho. Acho que é porque está no centro, que é mais próximo, hoje é um monumento."

Helder Torres, completa: "Antes da chegada do pessoal da UFMG, acho que foi em 87, para o Projeto Memória de Nova Ponte, eu nasci aqui em Nova Ponte; eu e um pequeno grupo escolhemos e fichamos oito casas para preservação. Apresentamos à CEMIG e eles disseram que não poderiam preservar todas, no máximo duas. E no ano de 89, essas duas casas foram registradas como acervo do patrimônio. A CEMIG, depois de uma grande luta, e já com a mudança do governo do Cardoso para o Hélio Garcia, aliviou um pouco. Mas tivemos que fazer pressão: da Fazenda Cachoeira, a Dona Alice que era a proprietária - não saiu da casa. Ficou morando lá, mesmo depois que a CEMIG comprou sua terras, até a prefeitura decidir o que fazer com a casa. Ficou decidido que a prefeitura compraria a casa e a CEMIG faria o transporte."

Já sobre a opinião dos moradores: "... não temos esta cultura de preservação, a escolha das casas foi pelo lado construtivo e técnico. A população da cidade velha tinha um laço afetivo era com a Igreja, com a ponte, estas eram as grandes questões afetivas. Mas a memória não era uma questão, não era o principal problema para se preocupar, quando... estou saindo das minhas raízes, as questões são: será para onde que eu vou? Será que vai ser bom? Como vai ser esta saída?".

Sobre estas edificações na cidade nova, continua: "Quem era daquela

${ }^{31}$ Moradora na cidade de Nova Ponte, em entrevista para a pesquisa em 2004. 
época, valoriza hoje, valoriza o Chalezinho e o Museu, acham bacana assim, mas naquela época tinham muito com o que se preocupar" ${ }^{32}$.

Também seria possível se pensar nas características funcionais já que os dois monumentos ${ }^{33}$ preservados passaram do domínio privado para o domínio público, ao abrigarem na nova cidade o Arquivo Público e o Museu de Nova Ponte ${ }^{34}$, nem sempre é fácil distinguir o que é reutilização do monumento de maneira espoliadora, de uma obra de preservação, considerando que esses novos usos podem representar o único meio de preservá-los. Quanto à questão do valor do monumento transferido ou reconstituído como uma réplica, o monumento histórico é uma invenção do Ocidente, mas mesmo o novo centro de Varsóvia só é um monumento porque é uma réplica: "ele substitui com fidelidade comprovada, entre outras coisas pela fotografia, a cidade destruída". Nas sociedades desenvolvidas, o monumento erigido para fins de rememoração está praticamente fora de uso. O povo japonês, por exemplo, sem reverenciar as marcas do tempo em seus monumentos como os ocidentais, constroem periodicamente réplicas exatas de templos originais, cujas cópias anteriores serão destruídas ${ }^{35}$.

Nos dois casos do chalezinho e do museu ainda está presente o sentido da casa, como o lócus da vida privada ${ }^{36}$. Nas pequenas cidades como na antiga Nova Ponte, o armazém evocava espaços domésticos, era extensão do lar dos proprietários, tinha na casa uma porta que ligava o espaço comercial ao íntimo. Na extensão da Rua Presidente Vargas, que em frente à Vila São Vicente, se encontrava estendido um grande varal comunitário, onde sob a

\footnotetext{
${ }^{32}$ Entrevista com Helder Naves Torres em dezembro de 2003.

33 "Chama-se monumento tudo o que for edificado por uma comunidade de indivíduos para rememorar ou fazer que outras gerações de pessoas rememorem acontecimentos, sacrifícios, ritos ou crenças" (CHOAY, 2001, p.18). Podendo de forma direta contribuir para manter a identidade de uma comunidade, constituindo uma garantia das origens e dissipando a inquietação dos começos e com a essência do monumento relacionado ao tampo vivido e à memória.

${ }^{34}$ Segundo CHOAY (2001).

${ }^{35}$ CHOAY (2001 p.25-26).

${ }^{36}$ CORREIA, (1999). Balzac que faz uma analogia com o caracol e sua concha, e o morador com seu interior - e no mesmo sentido Benjamin interpreta esse interior como o "estojo do homem privado... O lar surge novamente como lugar do bem, afastando os homens da bebida, as mulheres dos mexericos e as crianças das influências perigosas da rua", em oposição, a rua como domínio oposto ao da casa, tenderia a identificar-se com o público, o formal, o visível e o masculino - a casa, em princípio, vinculada ao privado, ao informal, ao invisível e ao feminino (SANTOS, 1985).
} 
sombra das roupas, os moradores se sentavam para "tomar a fresca". A velha Nova Ponte, segundo BRANDÃO (1997), era uma cidade pequena, onde o tempo passa devagar e que só lentamente foi se modificando. A casa onde 0 Seu Morse Caetano nasceu, passados sessenta e sete anos ainda estava de pé. O narrador Sebastião Soares contava que havia passado uma "vida inteira na Praça São Miguel". O armazém do Seu Preto estaria "assim" há mais de trinta e quatro anos. Os grandes lotes, as maritacas, as ruas, os banquinhos nas calçadas, o sorvete, as cadernetas dos fregueses nos armazéns, as "salas de estar" na rua, todos lugares de valor, banhados de lembranças e significações, são lugares da memória.

A percepção do lugar $^{37}$ pode ser feita pelo crivo científico ou cultural, mas sua configuração se dá por meio de práticas e formas econômicas, de sociabilidade, arquitetônicas e urbanísticas pelas quais se pode reconhecer a identidade de caráter privado (dizendo respeito à pessoa e ao grupo) e de caráter público, destinada aos outros, nas quais os códigos têm que ser claros e compartilhados a fim de possibilitar a comunicação. O processo de urbanização não pode fugir do debate da dimensão simbólica, inseparável da vida e que dá sentido ao espaço cotidiano: O espaço público pode ser apreendido sob formas específicas: como estruturador urbanístico e como principal cartão de visita do lugar... e para os residentes, é o elemento mais visível da ordem política, aquele cuja organização e normas mostram em que grau o lugar lida com conceitos de liberdade, democracia, respeito recíproco. O espaço público é um retrato do grau de coesão comunitária na medida em que desempenha uma função de forte peso na eficácia dos símbolos, pois reúne em si o maior número de pessoas que partilham dos mesmos códigos (YÁZIGI, 2001, p.202).

Segundo SANTOS (1985), para nossa cultura é impossível imaginar o urbano sem o recurso à noção e à imagem da rua, importância que pode ser percebida pela constatação da quantidade de atividades e significados para os

${ }^{37}$ Segundo YÁZIGI (2001). 
quais servem de apoio ou de "locus". A análise do espaço deve levar em conta as atividades que se dão em diversos recortes, "a rua é a forma de utilizá-la e o espaço é o uso que o permite", o que resulta em significados da sua conjugação com uma atividade podendo mudar de acordo com ela. A permeabilidade do público e do privado, ou da casa e da rua, em sua relação com os grupos que usam esse espaço, pode ser descrita da maneira que se segue: "a casa está para a família como a rua está para os moradores, por isso é que se pode dizer que os moradores formam uma grande família ou que esta rua é minha casa". A rua é o meio fundamental para a elaboração da cidadania e da civilidade. Os espaços urbanos não se limitam a ser palco da produção industrial, da troca de mercadorias, ou lugares onde os trabalhadores vivem. Eles são tudo isso e muito mais; são produtos: edifícios, ruas, placas, postes, árvores, enfim, paisagem que é produzida e apropriada sob determinadas relações sociais. A cidade é objeto e também agente ativo das relações sociais, ou seja, os espaços urbanos e o ambiente construído não constituem meros cenários para a sociedade, mas são parte dela ${ }^{38}$.

Ao observarmos os moradores da cidade passando o tempo em esquinas movimentadas, parando em bares e padarias, bebendo refrigerantes junto à porta de casa, o ponto fundamental da vida social nas calçadas é precisamente o fato de serem espaços públicos e reunirem pessoas que não se conhecem de maneira íntima, privada. A soma desses contatos públicos casuais no âmbito local resulta na compreensão da identidade pública das pessoas, uma rede de respeito e confiança mútuos e um apoio eventual na dificuldade pessoal ou da vizinhança. Trata-se de um tipo de empreita palpável que as calçadas possuem e de como são utilizadas na vida diária, cotidiana. Em coletividades pequenas, todos sabem da vida de todo mundo. A estrutura social da vida das calçadas depende em parte do que pode ser chamada uma figura pública autonomeada, pessoas que cuidam de lojas, bares e similares. A maioria dos personagens de rua está estabelecida em locais públicos, e todas as outras figuras públicas da rua dependem delas, ainda que indiretamente, pela existência na calçada de caminhos em direção a esses empreendimentos

${ }^{38}$ MARICATO (1997). 
e seus proprietários, criando uma identidade ${ }^{39}$.

Nas ruas, praças e esquinas, no espaço urbano, segundo BRESCIANI (1991), podem ser suporte de memórias diferentes, cenários contrastados, múltiplos, convergentes. Os discursos, escritos ou falados, envolvem um bairro, uma cidade e the conferem identidade, uma imagem cultural em movimento constante feito de pequenas subvenções.

39 A maneira de decifrar o que ocorre no comportamento aparentemente misterioso e indomável das cidades, segundo JACOBS (2000), é observar mais de perto as cenas e os acontecimentos mais comuns, tentar entender o que significam e ver se surgem explicações que lhes propiciem solo comum. 


\section{Capítulo 2}

\section{O direito à cidade de Nova Ponte: origem e luta}

Os estudos para o aproveitamento do rio Araguari, como fonte de energia, e a transferência da cidade para um local mais alto, foram propostos ainda na década de 30, época da emancipação do município. Desde então, a cidade de Nova Ponte passa a ter uma vida provisória, por causa dos seguidos adiamentos da construção da barragem.

A arquitetura da cidade sofreu uma grande degradação. Os últimos casarões do século XIX e início do XX caíram em descaso e as casas foram construídas sem a preocupação com a durabilidade. As reformas dos prédios públicos também não tiveram estímulo e os recursos teriam sido aplicados prioritariamente na zona rural. Alguns locais já se assemelhavam a cidades abandonadas, mesmo quando foram registrados cerca de seis mil habitantes em Nova Ponte. Por causa da iminente transferência da cidade, além do impacto social provocado pela longa espera, a construção prejudicou a economia da cidade. A mão-de-obra se tornou escassa para o comércio e a agricultura. Os comerciantes locais reclamavam das construtoras por terem montado uma infra-estrutura de serviços no próprio acampamento.

Do outro lado do rio Araguari, o distrito de São Sebastião da Nova Ponte guardava as mesmas características de mais de meio século atrás. Em volta da igreja, as ruas de terra levavam a velhos casarões com até 29 cômodos, lembranças do início do povoado (Figura. 33). Pouca coisa, no entanto, foi mantida na nova cidade construída pela CEMIG. De todos os exemplares a CEMIG decidiu manter apenas o "Chalezinho", uma casa que foi construída por escravos há mais de cem anos. O Chalé foi desmontado e reconstruído fora do alcance da águas da represa. Dona Maria Brígida, que era a moradora mais antiga de São Sebastião, com 90 anos de idade foi obrigada a abandonar a casa onde morou por 75 anos, relata: “'Eu pensei que só iria sair daqui morta. 
Mas não tem jeito, porque a água vai subir". ${ }^{40}$

As reações dos moradores da velha cidade com as mudanças foram as mais variadas. Alguns choravam, outros apostavam no futuro acreditando no discurso vigente na época de que o progresso era o mais importante. $O$ presidente da Câmara Municipal de Nova Ponte naquele momento era o Sr. Gerson Tomás da Silva, que declarou estar do lado dos progressistas. Para ele, não aceitar a construção da usina em uma época de escassez de energia, seria regredir no tempo. Mas ele não escondeu suas ambigüidades e disse: "Sou nascido e criado aqui. Meu coração não quer esta usina. Sou obrigado a aceitá-la, porque defendo o progresso". ${ }^{41}$

Em 1988, o prefeito Gil Carneiro de Mello, muito simpático ao governo Newton Cardoso, declarou que a construção da barragem era positiva. Ele admitiu que no início a população não aceitou a idéia da transferência, mas afirmou: "Hoje todos estão ansiosos para a mudança e muitos vão receber casas". ${ }^{42}$

Com opinião divergente quanto à satisfação dos moradores da cidade, o vigário de Nova Ponte, Pe Júnior, afirmou que foi de repente que a população começou a perceber que havia uma série de mudanças que estavam interferindo no seu comportamento e na sua cultura. O padre aponta outros problemas como a forma de condução da chegada das empresas na cidade e a total falta de informação: "Ninguém sabia o que ia acontecer e isso provocou um certo desequilíbrio social". ${ }^{43}$

\subsection{A estagnação da velha cidade}

O êxodo urbano e o impacto sócio econômico direto, ocorrido na velha

\footnotetext{
${ }^{40}$ Artigo de jornal intitulado "Uma história de meio século será afogada". Este recorte de jornal está arquivado no Museu de Nova Ponte, s.n. s.d.

${ }^{41}$ Recorte de jornal encontrado no Museu de Nova Ponte, s. n., 1988.

${ }^{42}$ Recorte de jornal encontrado no Museu de Nova Ponte, s. n., 1988.

${ }^{43}$ Recorte de jornal encontrado no Museu de Nova Ponte, s. n., 1988.
} 
cidade, durante a avaliação do projeto e a construção da usina hidrelétrica, podem ser observados através da análise comparativa de documentos oficiais, como os Recenseamentos de 1950/55 e diversos recortes de jornais, que retratam uma época de mudanças e incertezas, além dos relatórios públicos da CEMIG, que foram apresentados à população da cidade já na conclusão dos processos de indenização. Os textos e tabelas a seguir procuraram formar uma base para reflexão e comparação ao retratarem diferentes momentos históricos e modos de apropriação e uso do espaço, a partir da construção da barragem de Nova Ponte.

As tabelas 01 e 02, respectivamente sobre a localização da população e sobre os ramos de atividade desenvolvidos por esta população apontam para o predomino das atividades rurais. De 1950 - data do recenseamento - até 1991 - data do início do reassentamento - a velha cidade de Nova Ponte manteve as mesmas características mais rurais que urbanas. A maioria dos moradores da cidade encontrava trabalho prioritariamente no campo ou apenas desenvolviam uma agricultura de subsistência nas pequenas propriedades próximas da cidade ou em sítios ou chácaras na própria cidade. Da praça da matriz era possível admirar uma plantação de milho em um "quintal" próximo do centro da cidade velha. ${ }^{44}$ Estes "quintais" fizeram parte do cenário urbano de Nova Ponte e configuraram um período de mais de 40 anos de estagnação econômica.

${ }^{44}$ BRANDÃO (1997). 
Tabela 01. Localização da população de Nova Ponte em $1950 .{ }^{45}$

\begin{tabular}{|c|c|c|c|c|}
\hline \multirow[t]{3}{*}{ Localização da população } & \multicolumn{4}{|c|}{$\begin{array}{c}\text { População Presente } \\
\text { (1950) }\end{array}$} \\
\hline & \multirow[b]{2}{*}{ Homens } & \multirow[b]{2}{*}{ Mulheres } & \multicolumn{2}{|c|}{ Total } \\
\hline & & & $\begin{array}{l}\text { Números } \\
\text { absolutos }\end{array}$ & $\begin{array}{c}\% \\
\text { sobre o total }\end{array}$ \\
\hline Sede & 791 & 848 & 1639 & 20,61 \\
\hline Rural & 3344 & 2967 & 6311 & 79,39 \\
\hline Geral & 4135 & 3815 & 7950 & 100,00 \\
\hline
\end{tabular}

Fonte: Recenseamento Geral, Mapa Municipal Vol. IX 1950.

Tabela 02. Distribuição da população municipal segundo ramos de atividade em $1950 .{ }^{46}$

\begin{tabular}{|c|c|c|c|c|}
\hline \multirow{3}{*}{ Ramos de atividade } & \multicolumn{4}{|c|}{$\begin{array}{l}\text { População presente } \\
\text { De } 10 \text { anos e mais }\end{array}$} \\
\hline & \multirow[b]{2}{*}{ Homens } & \multirow[b]{2}{*}{ Mulheres } & \multicolumn{2}{|c|}{ Total } \\
\hline & & & $\begin{array}{l}\text { Números } \\
\text { Absolutos }\end{array}$ & $\begin{array}{l}\% \text { sobre } 0 \\
\text { total geral }\end{array}$ \\
\hline $\begin{array}{c}\text { Agricultura, pecuária e } \\
\text { silvicultura }\end{array}$ & 2279 & 55 & 2334 & 42,17 \\
\hline Indústrias extrativas & 10 & - & 10 & 0,18 \\
\hline Indústria de transformação & 54 & 1 & 10 & 099 \\
\hline Comércio de transformação & 48 & - & 48 & 0,86 \\
\hline $\begin{array}{c}\text { Comércio de imóveis e } \\
\text { valores imobiliários, } \\
\text { créditos, seguros e } \\
\text { capitalização. }\end{array}$ & 10 & - & 10 & 0,18 \\
\hline Prestação de serviços & 41 & 146 & 187 & 3,37 \\
\hline Profissões liberais & 5 & - & 5 & 0,09 \\
\hline Atividades sociais & 9 & 18 & 27 & 0,48 \\
\hline $\begin{array}{l}\text { Administração pública, } \\
\text { legislativa e justiça }\end{array}$ & 13 & 3 & 16 & 0,28 \\
\hline $\begin{array}{c}\text { Atividades Domésticas não } \\
\text { remuneradas e atividades } \\
\text { escolares discentes }\end{array}$ & 155 & 2208 & 2363 & 42,76 \\
\hline Condições inativas & 236 & 210 & 446 & 8,05 \\
\hline $\begin{array}{c}\text { Transporte, comunicações } \\
\text { e armazenagem }\end{array}$ & 32 & 1 & 33 & 0,59 \\
\hline Total & 2892 & 2642 & 5534 & 100,00 \\
\hline
\end{tabular}

Fonte: Recenseamento Geral, Mapa Municipal Vol. IX 1950.

${ }^{45}$ Segundo dados do Recenseamento Geral, Mapa Municipal Vol. IX 1950.

${ }^{46} \mathrm{De}$ acordo com os dados do Recenseamento Geral de 1950. 
A sede municipal da velha Nova Ponte, que surgiu de dois povoados, um de cada margem do rio Araguari, era cortada pelo mesmo e apertada entre as elevações que o margeavam. A sua principal atividade econômica era a agropecuária. Na agricultura destacava-se, quanto ao valor, a produção de arroz que, em 1955, atingiu 90000 sacos do produto não beneficiado, vindo em seguida a de milho, com 111000 sacos, no mesmo período. Além disso, o município produzia, de um modo geral, todos os demais gêneros de primeira necessidade, mas em escala reduzida para consumo próprio.

Na pecuária, além da criação própria de rebanhos bovinos e suínos, havia um grande comércio de gado para corte, adquirido de outros municípios, retido para engorda e revendido para os centros consumidores, através de Uberaba, Barretos e da capital paulista. O município era também um regular produtor de leite, atingindo em 1955, um milhão de litros. O beneficiamento de arroz era um dos sub-ramos industriais de maior importância para o município.

$\mathrm{Na}$ seqüência as tabelas 03, 04 e 05 registram as características da economia local, com destaque para a agricultura. A cidade de Nova Ponte foi considerada auto-suficiente na produção de alimentos, foi destaque regional no plantio da soja e na produção de leite. O quadro se altera a partir da construção da UHE Nova Ponte e o município é dominado pela pecuária para a criação e engorda de gado de corte.

Tabela 03. Dados da produção agrícola do município em 1955.

\begin{tabular}{|c|c|c|c|c|c|}
\hline \multirow{2}{*}{$\begin{array}{l}\text { Culturas } \\
\text { agrícolas }\end{array}$} & \multirow{2}{*}{$\begin{array}{l}\text { Área } \\
\text { (há) }\end{array}$} & \multicolumn{2}{|c|}{ Produção } & \multicolumn{2}{|c|}{ Valor } \\
\hline & & Unidade & Quantidade & Cr\$ & $\begin{array}{c}\% \text { sobre } \\
\text { o total }\end{array}$ \\
\hline Arroz & 48400 & Saco $60 \mathrm{Kg}$ & 90000 & 32400 & 56,12 \\
\hline Milho & 3380 & " " " & 111000 & 16650 & 28,83 \\
\hline Feijão & 1452 & " " " & 18000 & 6480 & 11,22 \\
\hline Outras & 452 & - & - & 2215 & 3,83 \\
\hline Total & 53684 & - & - & 57745 & 100,00 \\
\hline
\end{tabular}


Tabela 04. Situação dos rebanhos do município em 1955:

\begin{tabular}{c|c|c|c}
\hline Rebanhos & Número de cabeças & \multicolumn{2}{|c}{ Valor } \\
\cline { 3 - 4 } & & Cr\$1000 & \% sobre o total \\
\hline Asininos & 2 & 7 & 0,01 \\
\hline Bovinos & 18000 & 27000 & 65,93 \\
\hline Caprinos & 100 & 10 & 0,02 \\
\hline Eqüinos & 1500 & 2100 & 5,12 \\
\hline Muares & 800 & 2240 & 5,46 \\
\hline Ovinos & 200 & 16 & 0,03 \\
\hline Suínos & 12000 & 9600 & 23,43 \\
\hline Total & - & 40973 & 100,00 \\
\hline
\end{tabular}

Fonte: Recenseamento Geral, Mapa Municipal Vol. IX 1955.

Tabela 05. Organização industrial em 1955.

\begin{tabular}{|c|c|c|c|c|c|c|}
\hline \multirow{2}{*}{$\begin{array}{l}\text { Tipo de } \\
\text { indústria }\end{array}$} & \multirow{2}{*}{$\begin{array}{c}\text { № de } \\
\text { estabeleci } \\
\text { mentos }\end{array}$} & \multirow{2}{*}{$\begin{array}{l}\text { Pessoal } \\
\text { emprega } \\
\text { do }\end{array}$} & \multicolumn{2}{|c|}{ Capital empregado } & \multicolumn{2}{|c|}{ Força motriz } \\
\hline & & & Cr\$1000 & $\begin{array}{c}\% \text { sobre } 0 \\
\text { total }\end{array}$ & $\begin{array}{l}\text { № de } \\
\text { motores }\end{array}$ & $\begin{array}{l}\text { Potência } \\
\text { em c.v. }\end{array}$ \\
\hline $\begin{array}{c}\text { Indústria } \\
\text { extrativa mineral }\end{array}$ & 6 & 11 & 10 & 0,53 & - & - \\
\hline $\begin{array}{l}\text { Indústria de } \\
\text { transformação e } \\
\text { beneficiamento } \\
\text { da produção } \\
\text { agrícola }\end{array}$ & 7 & 13 & 870 & 46,77 & 5 & 50 \\
\hline $\begin{array}{c}\text { Indústria } \\
\text { manufatureira e } \\
\text { fabril }\end{array}$ & 2 & 5 & 980 & 52,70 & 4 & 132 \\
\hline Total & 15 & 29 & 1860 & 100,00 & 9 & 182 \\
\hline
\end{tabular}

Fonte: Recenseamento Geral, Mapa Municipal Vol. IX 1950.

$\mathrm{Na}$ década de 80, o município de Nova Ponte foi o maior produtor de soja do Triângulo Mineiro A cidade estava ligada ao resto do Brasil por rodovia asfaltada e por diversas estradas de terra, o que facilitava o escoamento de sua produção. A produção de soja do Município superou sua produção global do arroz, feijão, café e milho.

O jornal "O triângulo", de 27/01/84, destaca seus homens e mulheres ligados ao campo e a projeção que faziam para um futuro próximo com a manutenção destas atividades: 
Eis alguns dados: Luis Cadelca produziu, em 1983: 85 mil sacos. Vai produzir, em 1984, 100 mil sacos. Joaquim dos Santos Martins, em 1983: 55 mil sacos. Espera em 1984, 120.000 sacos. Pedro R. Guide, produziu no ano findo, 45 mil sacos. Estima, para 1984, uma produção de 90.000 sacos. Walter Detoni, em 1983, colheu 30.000 sacos. Deseja produzir em 1984, 50.000 sacos. Denito Sábile teve, em 1983, 30.000 sacos. Pretende colher no ano em curso, 60.000 sacos. Dona Jandira R. Prado, em 1984, 30.000 sacos. Deseja, em 1984, 50.000 sacos. Outros produtores merecem destaque: Massato Hatsuia, Hidero Nishi, Paulo Tadeu Cortez, Leoni Pedro Felino e Ademar Neumanm. Massato Hatsuia possui apenas 34 alqueires. Ele é o detentor da mais alta produtividade regional. Um autêntico campeão. Em 1983, colheu 8.000 sacos de soja, 3.000 sacos de café e 2.500 sacos de trigo. As suas terras são de inferior qualidade (O Triângulo, de 27/01/84).

No mesmo artigo, apesar da declaração "progressista" do prefeito, é notória a disponibilização das terras para arrendamento e venda na área rural do município, o que mudou o rumo das atividades e da oferta de trabalho na região. Ainda segundo o prefeito:

Ainda existem boas áreas para o cultivo da soja, a venda, por pessoas que, por esse ou aqueles motivos, desejam mudar de atividade. Outros pretendem arrendar suas terras. As áreas disponíveis aproximam-se dos 22 mil hectares. E acrescenta: 'Há procura por parte de gaúchos, paranaenses e paulistas $(O$ Triângulo, de 27/01/84).

Sobre a construção de uma represa pela CEMIG na região o prefeito declarou:

Com ou sem represa, Nova Ponte deve continuar com a sua marcha progressista. Na minha administração realizarei todas as obras previstas e não deixarei de ajudar aos que quiserem construir novas casas, novas obras, entre nós. A represa não é que assusta. Se ela for mesmo construída, o represamento das 
águas atingirá terras de fundo, de grotões e terras cansadas. Poderá atingir a cidade. O que for afetado mudarei para outro local, já escolhido pelos órgãos competentes ( $O$ Triângulo, 27/01/84).

A situação dos melhoramentos urbanos na sede municipal em 1954, conforme registros existentes nos Serviços de Estatística da Viação e da Produção de Minas Gerais pode ser resumida pelo quadro que se segue (Tabela 06).

Tabela 06. Melhoramentos Urbanos - dados de 1955.

\begin{tabular}{l|c}
\hline Especificação & Dados s \\
\hline Número de prédios existentes & 369 \\
\hline Logradouros públicos existentes & 29 \\
\hline Abastecimento de água: prédios servidos & 99 \\
\hline Abastecimento de água: logradouros servidos totalmente & 13 \\
\hline Abastecimento de água: logradouros servidos parcialmente & 5 \\
\hline Iluminação pública: logradouros iluminados & 22 \\
\hline Iluminação pública: ligações domiciliares de luz & 203 \\
\hline Iluminação pública: ligações domiciliares de força & 6 \\
\hline Fonte: Recenseamento Geral, Mapa Municipal Vol. IX 1955. &
\end{tabular}

\subsubsection{Serviços, equipamentos coletivos e condições de vida}

Em 1955, o território do município de Nova Ponte era cortado por 401 $\mathrm{Km}$ de estradas de rodagem, dos quais 26 sob a administração estadual, 125 sob a municipal e os restantes particulares. Era servida pela Estrada de Ferro Rede Mineira de Viação. Também foram registrados pela prefeitura Municipal os seguintes veículos motorizados: 10 automóveis, 12 camionetas, 15 caminhões e 3 ônibus.

Nesta data foram registrados pelo município: um estabelecimento comercial atacadista na sede; e 43 estabelecimentos comerciais varejistas, dos quais, 38 situados na sede. Dispunha de dois correspondentes bancários. 
Os resultados do Censo de 1950, referentes à alfabetização, fornecem os seguintes dados relativos à população do município (Tabela 07):

Tabela 07. Instrução Pública - dados de 1955.

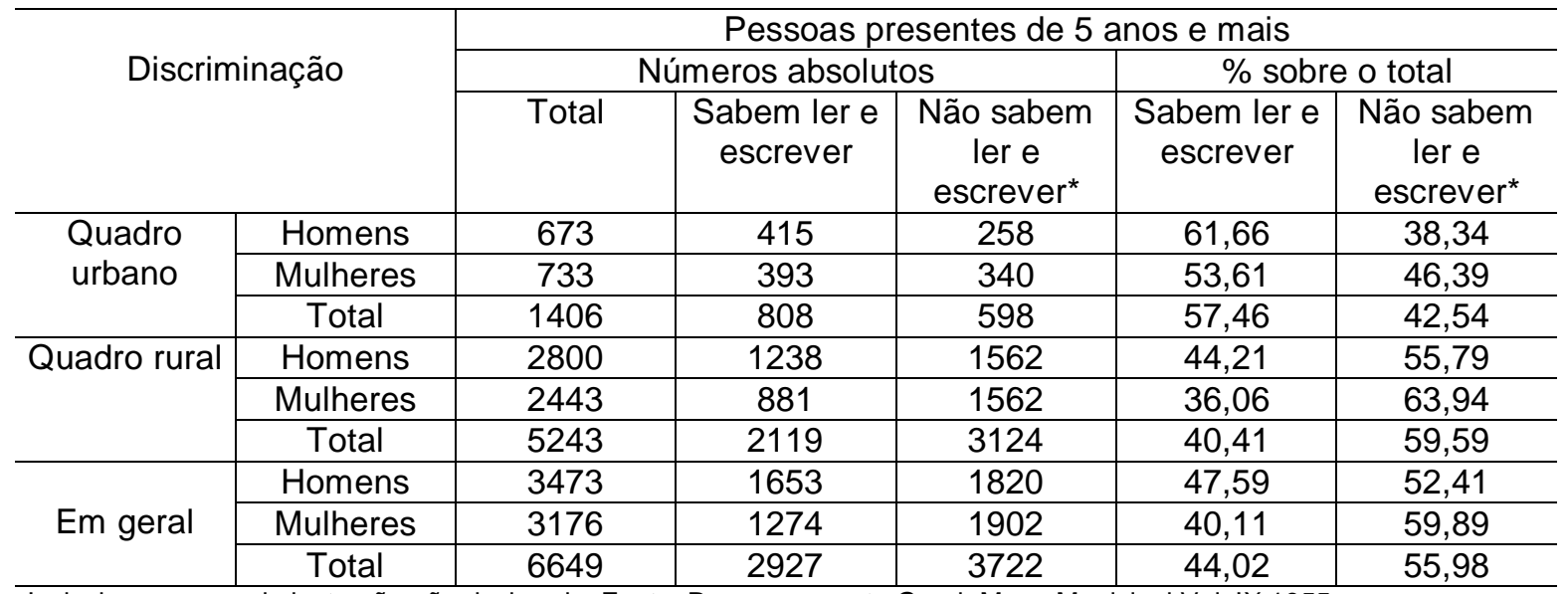

Inclusive pessoas de instrução não declarada. Fonte: Recenseamento Geral, Mapa Municipal Vol. IX 1955.

Segundo os dados do Serviço de Estatística da Educação do Estado de Minas Gerais, no período 1954-1956, foi registrada a seguinte a situação do ensino primário no município de Nova ponte (Tabela 08).

Tabela 08. Ensino primário no município de Nova Ponte em 1955.

\begin{tabular}{c|c|c|c}
\hline \multirow{2}{*}{ Especificação } & \multicolumn{3}{|c}{ Dados numéricos } \\
\cline { 2 - 4 } & 1954 & 1955 & 1956 \\
\hline Unidades escolares & 14 & 16 & 12 \\
\hline Corpo docente & 21 & 25 & 22 \\
\hline Matrícula efetiva & 629 & 726 & 784 \\
\hline Fonte: Recenseamento Geral, Mapa Municipal Vol. IX 1955.
\end{tabular}

A população, em 1955, usufruía um centro de saúde e dos serviços profissionais de um médico residente. Existia também uma biblioteca.

A discussão sobre o destino da cidade continua ao longo dos anos, mas em 1985, o prefeito Gil Carneiro de Melo se dispõe a cumprir suas promessas 
de campanha, apesar das severas críticas e um jornal local notifica: "Prefeito faz obras em cidade que será submersa por represa". 47

É comum ver as promessas dos candidatos se esvaírem após as eleições, no entanto naquela época, o prefeito de Nova Ponte estava disposto a demonstrar que palavra de bom político não volta atrás. No dia em que a cidade completou 47 anos, foi inaugurada a Santa Casa de Nova Ponte, e a obra foi avaliada em $\operatorname{Cr} \$ 400$ milhões. Outra obra foi a da rodoviária que foi entregue à população em julho de 1986, e segundo o prefeito, foi avaliada em Cr\$900 milhões. Em janeiro do mesmo ano, foi iniciada a construção do centro social, um investimento de $\mathrm{Cr} \$ 1,2$ bilhões. Os moradores da cidade divergiram da opinião do prefeito sobre as obras, como afirmou a moradora e supervisora de uma das escolas da cidade, Magda Gaspar: "Seu Gil é uma excelente pessoa, mas um péssimo administrador". ${ }^{48} \mathrm{E}$ afirmou a necessidade urgente do tratamento da água em Nova Ponte, onde o esgoto corria a céu aberto pelas ruas.

O médico Oscar Eduardo Azera Fontanila, afirmou que a água não tratada de da velha cidade de Nova Ponte foi a grande responsável pelos 20 casos mensais de diarréia aguda rotineiramente atendidos no posto de saúde, além do alto índice de desidratações e verminoses. O tratamento da água, segundo afirmou, seria prioritário sobre qualquer outro tipo de investimento na cidade. Segundo o médico: "Existiram interesses pessoais no fato de o Prefeito estar construindo uma rodoviária e ter construído um hospital. A renda vai reverter para o seu próprio bolso. O hospital (...) será administrado por uma fundação da Prefeitura, cujo Presidente é o filho do Prefeito... A lanchonete que funcionará dentro da rodoviária também ficará em família, ou seja, será administrada por um primo de Gil, João Fortunato, o "João Botina". 49

No jornal de Uberlândia, em 31/12/85, o prefeito tem em sua defesa um artigo com a seguinte chamada: "Uma cidade que não espera - Nova Ponte continua seu desenvolvimento enquanto aguarda os dias futuros".

\footnotetext{
${ }^{47}$ Recorte de jornal datado de 1985, s.n.

${ }^{49}$ Recorte de jornal datado de 1985, s.n.
} 
No artigo o prefeito declarou que sua administração deveria continuar trabalhando normalmente e que as necessidades do povo não poderiam ficar estagnadas até que o projeto CEMIG se tornasse realidade. Acrescentou que seu esforço e trabalho à comunidade estavam garantindo o desenvolvimento de Nova Ponte que contava naquele momento com cerca de 8.000 habitantes e se previa uma população flutuante de mais de seis mil pessoas durante a construção da barragem.

$\mathrm{Na}$ década de sessenta, a partir do início dos estudos para a implantação da usina hidrelétrica na região, a expectativa de aumento da população para a cidade de Nova Ponte foi frustrada. $O$ quadro que se configurou foi de total ausência de futuro com a morte anunciada da cidade, o que se agravou, na década de setenta, com as obras de construção da barragem e da vila operária. Uma análise comparativa entre os artigos de jornais e o documento do recenseamento de 1950 - quando foi registrada uma população, rural e urbana, de aproximadamente 8.000 habitantes, demonstra que a população local permaneceu praticamente estagnada. Depois de 40 anos da conclusão e publicação do censo, a população de Nova Ponte diminuiu para apenas 3.500 habitantes que foram indenizados e relocados para uma nova cidade - estes dados foram registrados em relatórios da CEMIG, e em informativos levados a público a fim de informar a população local sobre as negociações em andamento. Os recortes de jornais, além de registrarem o êxodo urbano e rural, denunciaram mudanças nas atividades econômicas: uma região de destaque no plantio de alimentos, principalmente da soja, passa a ter predominância da atividade pecuária de corte e sua área rural dominada pelas pastagens.

A vida na pacata cidade de Nova Ponte começou a mudar. Em um artigo de jornal foi considerada uma cidade jovem com seus 49 anos de emancipação e secular por seus arraiais - São Miguel e São Sebastião - entretanto, mesmo jovem com seus 49 anos de emancipação política, Nova Ponte desapareceu. 0 prefeito Gil Carneiro de Mello, falou da dor que sentia no coração quando pensava na inundação das igrejas de São Miguel e São Sebastião, da pracinha, do salto onde aprendeu a nadar, que foram condenados ao desaparecimento. A população não se queixou, admitiu que haveria progressos 
e melhorias sociais para todos, mas declaravam no artigo: "nosso coração dói quando pensamos na mudança" (Projeto Terra, 1987).

As mudanças se aceleraram a partir da visita do governador Newton Cardoso, no dia 23 de julho, que esteve na cidade para descerrar a placa da pedra fundamental da cidade nova e anunciar o início das obras da usina hidrelétrica. $O$ custo da cidade e da usina foi orçado em meio bilhão de dólares. A população praticamente dobrou, e aumentou ainda mais em dois anos aproximadamente, quando passaram de 5.000 pessoas envolvidas na construção da usina hidrelétrica, da rodovia MG-190 e a cidade nova. O planalto do Araxá dentro de alguns meses começou a sofrer drásticas mudanças em seu verde cenário, que foi encoberto pelas águas.

As ruas estreitas, o calor humano, o aconchego da velha Nova Ponte; a igreja de São Miguel, a de São Sebastião, a pracinha, a dor, ficou a memória de um tempo vivido, do jeito gostoso do sertanejo. Os mais velhos lembravamse dos bons tempos, os mais novos experimentaram a ansiedade pela mudança $a^{50}$.

\subsection{A Vila}

Um acampamento foi construído com características de cidade para abrigar o enorme contingente de trabalhadores. E hoje é conhecido como a vila residencial - um bairro da cidade nova - onde a maioria dos moradores e proprietários fez parte desse contingente atraído pela obra. A vila operária foi um núcleo fechado, totalmente controlado pela CEMIG, foi um acampamento de barrageiros nos moldes tradicionais.

A primeira proposta da CEMIG era reassentar na vila operária o maior número de habitantes que fosse possível abrigar da população da cidade que seria inundada, ao restante desta população seria oferecida uma indenização

${ }^{50}$ (Projeto Terra, 1987) 
em dinheiro. Para isso, a vila foi planejada e construída com dupla finalidade: à de atender as obras da usina e ao que viria a ser a nova cidade de Nova Ponte.

$\mathrm{Na}$ vila foram construídas casas de alvenaria e uma infra-estrutura urbana de qualidade para atender a uma cidade de até 5.000 habitantes. Para os trabalhadores solteiros e braçais foram construídos alojamentos provisórios e coletivos. Os solteiros de nível técnico foram acomodados em casas, algumas delas de madeira e para os casados e suas famílias, o pessoal mais qualificado, com nível universitário, os diretores e as pessoas ligadas ao comércio da vila e serviços foram construídas boas casa de alvenaria.

A construção da vila, a nove quilômetros da velha cidade, criou uma série de conflitos, tal como declara o Pe Júnior: "Foi um desrespeito com o povo, com a população de Nova Ponte, porque os moradores da vila residencial ficavam totalmente afastados da comunidade. Era um povo que se sentia diferente, de cultura diferente. Esse pessoal ficava lá na vila com escola própria, tinham vida própria... Houve muitos conflitos, problemas de aceitação, lá tinham supermercados, tinham tudo. A vila era uma cidade maior que Nova Ponte, bonita e tudo, com clube e piscina".

Além dos trabalhadores fixos da vila foi necessária a contratação pelas empreiteiras e suas associadas de mão-de-obra flutuante, trabalhadores conhecidos como "os peões" em Nova Ponte, que se alojavam nas periferias da cidade. A CEMIG havia iniciado as obras da vila e começaram a chegar "os peões" e, em menos de um ano, a cidade aumentara em $50 \%$ o número de habitantes urbanos.

Segundo o Pe. Júnior em entrevista: "Começaram a construir a vila e em menos de um ano, estava tudo pronto. Para a população, a construção da vila foi um ato muito agressivo, profundamente agressivo e a comunidade sofreu muito. Chegava gente de todos os lugares de 200 a 300 pessoas por dia, vinha gente do Brasil inteiro, você não sabia quem eram, vinham assassinos, drogados, vinha de tudo. Atendi muita gente que dizia: 'matei um ontem... anteontem... três dias atrás... matei duas pessoas... estou aqui, fugido!' Situação que era muito comum, não tínhamos como controlar. Os peões 
também eram marginalizados por serem peões. Por isso me tornei interlocutor deles, muitas vezes para negociar com a empresa por melhores salários ou durante a paralisação. O chefe deles era o chefe da CEMIG, com poder de decisão e o negociador era o padre. Outra tentativa de diminuir a marginalidade e violência foi a construção de um barracão, atrás da minha casa; comprei 200 colchões e os abriguei na casa paroquial. Lá, eu oferecia música, comida e galinhada. Era uma forma deles ficaram ali, bebiam e ficavam bêbados ali também. Muitos desses peões eram casados e me davam o dinheiro do salário para guardar, para que não gastassem na zona. A zona de Nova Ponte era composta de nove casas e em menos de um ano chegaram mais de 300 mulheres, que vinham de Uberaba, Uberlândia e dessas cidades maiores, só para pegarem o dinheiro do mês da 'peãozada'. Com isso muita gente ficou na cidade, casou...Ficou por aqui e não quis voltar. Mas, houve muitos outros problemas, muitas meninas ficaram grávidas, mães solteiras... Foram problemas muito fortes e a comunidade não estava preparada".

A chegada da população para a construção da usina e a formação da vila operária tiveram impactos consideráveis sobre a vida cotidiana na antiga cidade. Segundo Vicentini (1992), seria importante examinar o processo histórico que se refere à transferência e a reprodução da vida e seu esvaziamento, que acabou por atingir toda a cidade.

Para a relocação da cidade de Nova Ponte a CEMIG prometeu à sua população a construção de uma nova cidade dentro dos "modernos padrões de urbanismo e com toda a infra-estrutura necessária ao bem estar de uma comunidade" ${ }^{51}$. Em seus informativos a empresa garantia que na futura cidade todos os seus moradores teriam acesso aos serviços públicos, um moderno sistema de abastecimento de água, de esgotamento sanitário com tratamento, rede de energia elétrica e telefonia, drenagem pluvial, vias pavimentadas, áreas de lazer, etc. Todas as edificações públicas seriam projetadas e construídas pela CEMIG. Seriam construídos: "o Fórum, a sede da Prefeitura Municipal e da Câmara Municipal, além de escolas de primeiro grau, uma delegacia, um novo cemitério, um centro cultural, três campos de futebol,

${ }^{51}$ CEMIG Notícias, março de 1988. 
centro de saúde, um núcleo esportivo, etc". Com relação às edificações particulares, a Companhia Energética de Minas Gerais adotaria dois procedimentos: "primeiro a indenização justa, dentro dos moldes tradicionais, permitindo ao indivíduo construir sua nova edificação, sendo-lhe doado um lote na nova cidade, podendo inclusive, aproveitar todo o material de sua antiga construção. A segunda forma, será a modalidade de permuta, na qual a CEMIG está desenvolvendo projetos padrões de residências, que dentro de uma mesma faixa de valor da propriedade a ser permutada, serão oferecidos à escolha do proprietário"52.

Neste processo de relocação da cidade, a CEMIG desenvolveu o projeto 'Memória da cidade', que levantou sua história social, arquitetônica e urbanística da cidade. Este acervo foi repassado à comunidade e está exposto no 'Centro Cultural' - hoje o Arquivo Público de Nova Ponte.

A velha cidade contava com aproximadamente 3 mil e 500 habitantes e cerca de mil lotes. A nova cidade, nos moldes propostos pela CEMIG, teria 1 mil e 800 lotes, incluindo aí, 76 lotes industriais, que irão permitir alocar micro empresários da região. Para o engenheiro Rômulo Antônio Gouveia Franco, um dos responsáveis pela obra: "a nova cidade será a única em Minas Gerais com infra-estrutura de água, energia, tratamento de esgoto, pavimentação e urbanização". Ele acreditava que a mudança seria tranqüila e sem conflitos. Sobre os problemas de indenização, Rômulo Franco disse que há duas soluções: "na primeira, as pessoas que desejassem receber a casa e a segunda as que desejassem a indenização. No caso dos que optassem pela moradia, a CEMIG faria a construção dentro do seu padrão. Aqueles que desejassem ser indenizados, a CEMIG pagaria o preço mais justo e disponibilizaria um lote na nova cidade para a construção da casa" ${ }^{53}$.

Das 1.336 unidades residenciais em Nova Ponte, 1.098 foram indenizados em dinheiro e 227 preferiram permutar o atual imóvel por outro a ser construído pela CEMIG na nova cidade de Nova Ponte. O presidente da CEMIG, Carlos Eloy, explicou: "acertando essas indenizações, a empresa está

\footnotetext{
${ }^{52}$ CEMIG Notícias, março de 1988.

${ }^{53}$ Triângulo Mineiro, s.d.
} 
resgatando um compromisso assumido com a comunidade local. Na verdade, a CEMIG tinha um débito com a população de Nova Ponte que estava ansiosa em resolver a questão da relocação; em menos de um ano, cumprindo determinação do governador Hélio Garcia, conseguimos colocar a pendência em dia”. Segundo ele a cidade seria a mais moderna e completa do país em termos de conforto, traçado e infra-estrutura básica.

Segundo um artigo de jornal encontrado no Museu Rural de Nova Ponte, a população se transferiu de maneira gradativa da velha para a nova cidade. Naquele momento a nova cidade já possuía 364 moradias habitadas e quase 500 em construção, além dos prédios públicos. Na área rural, os processos de indenização também estavam praticamente concluídos.

A área total desapropriada foi de 43.726 hectares e dividida em 1.486 imóveis. Somente com as indenizações particulares nas áreas urbanas e rurais, a CEMIG teria investindo US\$ 40 milhões ${ }^{54}$.

Segundo o presidente da CEMIG, Carlos Eloy 55: "assumimos o compromisso de agilizar as indenizações dos moradores da área urbana que vinham sendo proteladas há vários anos. Existem, hoje, na nova cidade mais de 400 casas em construção, vários prédios públicos já foram concluídos e outros estão em execução". Carlos Eloy observou que as indenizações alcançaram um grande avanço com a postura da CEMIG em negociar e pagar um preço justo para os imóveis urbanos e rurais: "essa foi uma das determinações do governador Hélio Garcia e nós a estamos cumprindo". A intenção da CEMIG foi de manter o cronograma das obras da represa, e esperava a entrada em operação comercial para o segundo semestre de 94 . 0 presidente afirmou que Nova Ponte seria de grande importância para Minas e se configurou como a retomada de crescimento econômico conforme desejava - Governo Federal. "Minas precisa da energia de Nova Ponte para manter o ritmo de crescimento e atrair novos empreendimentos", concluiu Carlos Eloy, e lembrou que a última usina construída pela CEMIG foi Emborcação já inaugurada há mais de 10 anos.

\footnotetext{
${ }^{54}$ Recorte de jornal encontrado no Museu Rural de Nova Ponte, s.d., s. n.

${ }^{55}$ Recorte do Jornal O Interior, s.d.
} 
A área inundada pela Usina de Nova Ponte foi de $443 \mathrm{~km}^{2}$ e atingiu diretamente oito municípios mineiros - Nova Ponte, Santa Juliana, Perdizes, Sacramento, Iraí de Minas, Patrocínio, Pedrinópolis e Serra do Salitre. Conforme levantamentos realizados pela CETEC - Centro Tecnológico de Minas Gerais, em agosto de 1987, esta área era constituída de $87 \%$ de pastagens, $8,5 \%$ de matas secundárias, $4 \%$ de mata ciliar e 9,5\% de cultura de subsistir. A licença da COPAM condiciona que a CEMIG deveria executar diversos programas ambientais dentro dos temas previamente estudados pela própria empresa, que foram: geologia / geomorfologia; uso da terra / cobertura vegetal; uso do solo / aptidão agrícola; recursos minerais, patrimônio paisagístico, patrimônio arqueológico; clima, flora terrestre, fauna de vertebrados terrestres; ictiofauna, limnologia; qualidade das águas; flora aquática; sócio-econômica, saúde, saneamento, preservação da memória histórica da cidade, etc. Os levantamentos e estudos relativos a estes temas foram contratados em sua maioria pela empresa Leme Engenharia e contaram com a participação de diversos órgãos como a CETEC, Fundação João Pinheiro, Escola de Arquitetura da UFMG, Secretaria de Saúde do Estado e outros. A partir destes estudos, foi produzido o plano diretor do reservatório, onde foram documentados programas e ações que deveriam minimizar o impacto sócio - ambiental causado pela obra. ${ }^{56}$

A análise dos documentos aqui reproduzidos demonstrou os problemas que atingiram diretamente a cidade de Nova Ponte e a região: o êxodo rural e urbano, além da migração forçada; aumento do desemprego, doenças e violência; insegurança para a população em geral; desaparecimento de terras férteis; diminuição sensível na produção agrícola e de subsistência, sendo substituída por pastagens; perda de identidade cultural e uma visível manipulação da mídia em favor dos interesses "progressistas" - mas, progresso a que custo? - Perguntam os afogados em Nova Ponte. Essa é uma pergunta fundamental, não só para Nova Ponte, mas para todos, pois nela está inserida a questão da modernização.

${ }^{56}$ Jornal da CEMIG, novembro de 1987. 
Há dúvidas quanto à vida útil da barragem, que não justificaria os sacrifícios impostos à população envolvida. O geólogo Sandor Grehs, adverte que no caso de Itaipu ${ }^{57}$, a usina "terá vida útil de no máximo 30 anos", em conseqüência da erosão e do acúmulo de terra no fundo da barragem. Segundo WALDMAN (2002), esse diagnóstico pode ser estendido à maioria das barragens, cuja tecnologia copia padrões de países temperados. Outra questão levantada por economistas, diz respeito ao agravamento da crise econômica do país e empobrecimento dos municípios e regiões inundadas, com o aumento do endividamento interno e externo, como observou Oswaldo Sevá, a dívida do setor já alcançava US\$ 30 bilhões, correspondendo a $25 \%$ de toda a dívida externa do país (PIB/CEDI, 1991, p.80).

\subsection{A região: insegurança e o início de uma organização popular}

Em fevereiro de 88, o Jornal do Campo publica o seguinte artigo: "Usina de Nova Ponte deixa região insegura":

A construção da barragem de Nova Ponte tem preocupado os produtores rurais daquela região. Os primeiros levantamentos efetuados pelas Centrais Elétricas de Minas Gerais - CEMIG, estatal mineira responsável pela obra na represa localizada no leito do rio Araguari, concluem que se inundará cerca de 410 $\mathrm{Km}$ quadrados, acarretando aos municípios de Pedrinópolis, Santa Juliana, Iraí de Minas e Nova Ponte, uma sensível redução em suas áreas cultiváveis (Jornal do Campo, fevereiro de 1988).

Sem obterem informações concretas sobre 0 pagamento das indenizações aos proprietários dos imóveis nas áreas inundáveis, as lideranças dessas cidades se uniram e fundaram a Associação de Prefeituras, Proprietários Rurais e Sindicatos dos vales dos rios Quebra-anzol e Araguari ARPA -, para obtenção de maiores informações e justas indenizações. No

\footnotetext{
${ }^{57}$ Jornal do Brasil, edição de 23/04/91.
} 
mesmo artigo, o Prefeito de Pedrinópolis, Fausto Pereira da Silva afirmava: "as nossas preocupações tiveram início após tomarmos conhecimento de outras desapropriações feitas pela CEMIG, para novas construções”. Segundo Fausto, os proprietários que venderam suas terras para a empresa, só conseguiram comprar outras áreas muito inferiores em tamanho e no preço, porque não foram indenizados a partir dos valores de mercado. O prefeito alega que não se conseguiam informações precisas da empresa: 'Sempre que tentamos obter informações, o máximo que conseguimos são respostas evasivas e promessas de que uma empresa especializada está fazendo um levantamento para se tomar decisões”. O prefeito afirmou que a CEMIG estava vendo a questão de uma maneira geral, esquecendo de um grande problema que é a formação de "ilhas" que inutilizariam um grande número de estradas rurais, e fariam com que as propriedades não atingidas pela água, ficassem praticamente isoladas, o que criaria um grave problema de transporte. Para as prefeituras, ficaria o ônus de construir novas estradas vicinais e o pagamento de indenizações para os ruralistas pelas terras das novas estradas. E Fausto perguntava: "Quem irá pagar estes gastos?”

O secretário executivo da ARPA, o ex-prefeito de Pedrinópolis, Antônio José Gondim, levantou a questão da utilização da energia produzida na hidrelétrica. Segundo o secretário ${ }^{58}$ : "A nossa região não terá lucros, com a barragem, devido termos energia suficiente para o próprio abastecimento. Teremos nossas terras inundadas, nossa produção diminuída, acarretando uma queda drástica no recolhimento do ICM destes cinco municípios, para que o Governo venda, e barato, a energia que será produzida aqui. Em resumo, estes municípios estão subsidiando a industrialização de São Paulo, Rio e Nordeste. Com a inundação das áreas cultivadas, o município perde em arrecadação e aumento do êxodo rural".Gondim afirmava que se houvesse um plebiscito na região, os votos contrários à barragem alcançariam 99\% do total: "Ninguém quer, nem autoridade, nem população. Mas a obra está sendo construída, à revelia de nossa vontade".

${ }^{58}$ Jornal do Campo, fevereiro de 1988. 
Segundo o presidente da ARPA, José Humberto, os pecuaristas que sempre trabalharam com a terra não pensavam em se desprender de seus bens, mas infelizmente estavam sendo obrigados a abandonar suas propriedades para a construção da hidrelétrica. José Humberto afirmava que a questão do assentamento seria levada até o fim das negociações pela ARPA e pelas comissões então formadas, por se tratar de uma questão judicial e para evitar o caos na região, como aconteceu em Emborcação - local onde o pequeno produtor hoje está apanhando café. José Humberto ressaltou que as escrituras dos proprietários não seriam passadas individualmente. As negociações aconteceriam em conjunto e seriam assistidas pelas comissões para que o peso de uma seja o contrapeso de outra, evitando um grande prejuízo. Segundo ele: "em reunião, um diretor da CEMIG declarou que a democracia estava chegando, mas a lei permanecia a mesma. Por isso, a ARPA não abrirá mão das negociações em conjunto" ${ }^{59}$.

$\mathrm{Na}$ cidade de Nova Ponte, um dos jornais locais registra a expectativa de sua população de um artigo intitulado: "E Nova Ponte vai desaparecer". No decorrer do texto são encontradas narrativas de alguns atingidos sobre a questão do reassentamento: "Diante da triste realidade do desaparecimento da cidade de Nova Ponte, este Repórter resolveu ouvir opiniões de pessoas natas e os que aqui aportam. Encontramos opiniões diversas, mas todas com o mesmo sentimento: SERÁ QUE VAMOS TER UMA 'NOVA' NOVA PONTE, com o mesmo carisma que estávamos acostumados? - Os bancos do Jardim, Ponte do rio, - O Salto, tudo isto é REALIDADE, são coisas que conhecemos e que o tempo não apagará de nossas mentes. Para os mais jovens não acostumados a esta realidade tudo é novidade e, seu sentimento não espelha saudades. - mas o adulto chega às lágrimas, seu sentimento é indescritível. Eis aí as opiniões:

Pe. Júnior: 'Penso que o desaparecimento de Nova Ponte trará para todos nós a importância de saber conservar e lutar pelo que é nosso.'

59 Jornal O Tempo, 27/02/88. 
Sargento Trindade (Militar): 'O desaparecimento de uma cidade, sepulta muito de sua tradição, mas também é o momento de se pensar em erigir uma cidade melhor estruturada e melhor dirigida.'

Clodoveu Jacó - Fazendeiro: 'É a pior coisa que foi implantada em nossa região, porque existem outras regiões em que poderia ser construída a hidroelétrica que em razão disso não perderíamos nossa cidade".

Hipólito Florêncio - Administrador: ' Para nós, povo de Nova Ponte, melhor é se não acabasse a cidade.'

Reginaldo Verri - Comerciante: 'É o preço do progresso.'

Wando Inácio - Diretor escolar: 'Um motivo de tristeza, mas para nossos filhos, será uma cidade de progresso.'

Ismael Faquin - Bancário: 'Nova Ponte não vai desaparecer, simplesmente mudará de lugar.'

Sebastião Najá - Aposentado: 'A tristeza é bem maior que a alegria pelo desaparecimento da cidade.'

Marli Fernandes - Dona de casa: ' Realmente não é bom o desaparecimento; teremos que recomeçar de novo e, isto demanda tempo, já pensou até vermos nossas árvores dando frutos?'

Marciel Carneiro - Comerciante; 'Por um lado é muito ruim, porque o povo perde suas tradições, mas também existe o lado positivo que vai ser uma cidade planejada com infra-estrutura que talvez nunca pudéssemos alcançar.'

Luiz José de Souza - Operador de Máquinas: 'Não é bom para ninguém o desaparecimento de uma cidade.'

Marinho Martim Severino - Técnico em contabilidade: 'Se realmente nós tivermos uma cidade nova, com tudo planejado, é aceitável - caso contrário...'

José Humberto Resende - Presidente do Sindicato Rural: 'Toda nossa estrutura será abalada, no entanto se for feito um trabalho consciente das 
lideranças, tem tudo para sairmos de uma cidade onde o desenvolvimento deixa a desejar, para uma cidade com tudo para crescer, desde o setor rural até o urbano propriamente dito.'

Iozaino José Carneiro - Professor e Diretor do Jornal AÇÃO NOTÍCIAS: ' Os novapontenses de modo geral, jamais se importariam com a preservação de nossa Tradição Cultural, caso não estivesse a velha cidade nos últimos suspiros. Não creio que Nova Ponte perderá muito em termos de tradição, já que a nova cidade contará com um museu para preservar sua cultura. Em termos econômicos, as terras férteis às margens dos rios não mais produzirão frutos, mas por outro lado, a hidroelétrica proporcionará além de empregos, a possibilidade de Nova Ponte vir a ser grande polo industrial, num futuro próximo“ (Jornal Ação Notícias. Junho/1988) ${ }^{60}$.

Em 1985, Nova Ponte era um olhar posto sobre o horizonte de sua história. Não muito diferente daquele que se entrevê no discurso do seu primeiro prefeito:

“(...) e o que de coração, almejo é que tão boa gente não perca jamais a confiança no futuro, a fé inabalável em seus sagrados destinos" (Octávio Veiga, 1939).

Na cidade de Pedrinópolis-MG, em 12 de abril de 1991, houve uma reunião com os prefeitos da Associação da Microregião do Planalto de Araxá61, a União Democrática Ruralista do Alto Paranaíba e a Associação dos Afogados. Nesta reunião, o Pe. Júnior ao fazer uso da palavra, cobrou dos prefeitos uma participação mais eficaz junto a CEMIG. Lembrou que a população de Nova Ponte estava cansada de tantas promessas por parte dos políticos e afirmou que nada de concreto tinha sido realizado em favor dos

\footnotetext{
${ }^{60}$ Entrevistas feitas pelo repórter Vicente de Paulo Moreira. Nova Ponte (1988).

61 Trata-se da AMPLA - Associação dos Municípios do Planalto do Araxá - composta por prefeitos e lideranças dos municípios atingidos pelas águas da barragem da hidrelétrica de Nova Ponte, são elas: Nova Ponte, Sacramento, Santa Juliana, Pedrinópolis, Perdizes, Serra do Salitre, Patrocínio e Iraí de Minas.
} 
afogados até aquele momento ${ }^{62}$. Em seu discurso, o padre destacou que 0 problema não era só de Nova Ponte, mas de toda a região.

Sobre o não comparecimento na reunião dos Deputados Estaduais da região e de um único representante em Brasília, o Pe. Júnior lamentou afirmando que realmente era triste não ter um representante no Estado, isto mostra a incoerência dos homens que nos deveriam representar: "na hora do voto, eles estão conosco, na hora que assumem postos na sociedade para nos representar simplesmente eles mandam recados, telegramas ou telefonemas e os compromissos assumidos de fato que ficam nas sedes em Belo Horizonte ou Brasília. Se nós estamos abertos a nos sacrificar por uma luta que é conjunta, eles também têm responsabilidade em sacrificar seja o deslocamento até o local, ou outro caso qualquer. Deveriam se lembrar que foi a região que os elegeu e para nos representar. Eu vejo isto com muita tristeza”.

Em 1991, um artigo no Jornal das Gerais intitulado "Hidroelétrica de Nova Ponte é um problema sem solução", traduz o sentimento de insegurança vivido pelos afogados:

A previsão da CEMIG para o término da obras está feita para setembro de 1993, conforme seu presidente Carlos Eloy, mas o que está preocupando não é o enchimento do reservatório, e sim as indenizações das terras aos produtores rurais, que mais uma vez estão sendo ludibriados pelos grandes, e ninguém, até a presente data, tem feito alguma coisa para, pelo menos, tentar salvar esta classe, a não ser grandes promessas de alguns políticos, quando solicitados. E a resposta é sempre a mesma: 'Isto não pode acontecer, nós vamos tomar uma decisão junto ao Governador e se preciso for, vamos até o Presidente da República'. Como no Brasil, tudo para ser resolvido é preciso se formar uma comissão, a Associação dos Afogados se reuniu e, para não fugir à rotina, também formou uma comissão com os poderes e o objetivo de elaborar um documento, ou seja, uma carta ${ }^{63}$ onde alguns políticos da

\footnotetext{
62 Jornal das Gerais, 1991.

63 "SOS Nova Ponte", Carta publicada no jornal "A boca do Povo", Nova Ponte, s.d.
} 
região se comprometeram a assinar, para depois ser entregue ao Presidente da CEMIG, solicitando mais rapidez nas negociações das terras e pagar um preço justo aos proprietários rurais. Esta comissão é formada por um representante de cada município atingido... A única esperança que resta para os proprietários rurais, é de que, em 1992, tudo indica que vai haver eleições para prefeitos e vereadores, aí vem os interesses particulares podendo ser resolvido este grande problema, caso contrário podem correr que as águas vão cobrir todas as terras e tudo fica como antes. Sem solução" (Jornal das Gerais, 05/10/91).

Durante todo o período da construção da usina, a atuação das associações - ARPA e AMPLA - foi por várias vezes questionada, como documentam os recortes de jornal aqui reproduzidos. A dissolução dessas associações se deu com o final das negociações no campo. O mesmo ocorreu com a AMNP - Associação dos Moradores de Nova Ponte, que teve início em 1988, em movimento liderado pelo pároco do município, o Pe. José Lourenço Júnior, quando a cidade de Nova Ponte estava em vias de desaparecer. Com destacada atuação até o final do reassentamento da população na nova cidade, através da união dos "afogados" - como eles próprios se intitularam.

Qualquer projeto que venha a interferir em um meio urbano constituído põe em questão as estruturas da sociedade existente e das relações imediatas - individuais - e cotidianas, e vai além, com as estruturas que se pretende impor através da via coercitiva e institucional. Os dispositivos científicos, na estratégia urbana, contribuem com elementos para um programa que projeta na prática, muitas vezes, a ideologia dos tecnocratas. 


\section{Capítulo 3}

\section{O setor elétrico e o cenário político brasileiro: a definição da categoria dos grandes projetos e a identificação dos atores envolvidos no processo}

A história brasileira recente tem revelado o conflito entre os interesses desenvolvimentistas com a construção de barragens e as populações residentes nas áreas a serem inundadas. O estudo do caso da cidade de Nova Ponte que teve sua área urbana totalmente inundada pelas águas da barragem da UHE Nova Ponte e sua população reassentada em uma nova cidade construída a três quilômetros da antiga, demonstrou uma evolução nos mecanismos de negociação que permitiram uma maior interação entre os setores atingidos e a CEMIG - Centrais Elétricas de Minas Gerais -, a concessionária responsável pelo projeto ${ }^{64}$.

A construção de uma usina hidrelétrica se insere na categoria dos "grandes projetos", categoria utilizada por cientistas sociais de diferentes áreas, indicando a mobilização de expressivos recursos financeiros, tecnológicos e humanos por parte de grupos econômicos nacionais e estrangeiros de grande porte, em geral coordenados pelo Estado, vinculados à ocupação territorial e ao crescimento econômico, com grande impacto nas esferas local, regional e nacional.

A prática recorrente do setor elétrico quanto às pessoas residentes nas áreas afetadas consistia na desapropriação das extensões territoriais onde

64 Ao longo dos anos noventa ganhou importância a idéia de conceber projetos de desenvolvimento no setor elétrico sob novas bases sociais, que não impliquem na concentração da propriedade sobre os recursos territoriais, nem a desestabilização sóciocultural das populações, que estabeleceram laços históricos de conhecimento e construção identitária com seus respectivos territórios. Segundo ACSELRAD (2001, p.79-90): "tal modelo deverá romper com o velho pacto conservador que assegurou longa vida à concentração fundiária no país, bem como resistir às tentativas de privatização dos recursos energéticos que possibilitariam uma onda de um novo tipo de expropriação do campesinato, das comunidades indígenas e das populações extrativistas". 
eram instaladas as usinas, mediante pagamento de indenizações, sendo concedido aos habitantes um determinado prazo para uma migração individualmente programada. Este tipo de tratamento representou historicamente a forma como se dava o remanejamento populacional.

A mudança e a inserção dos atingidos em um novo ambiente sem preparação causa a desestruturação familiar ${ }^{65}$, perda de identidade e marginalização. A desapropriação das extensões territoriais, para a instalação da usina, tradicionalmente reforça a exclusão social com potenciais impactos nos segmentos sociais atingidos como a perda de renda da população e proprietários rurais, perda de valor das áreas urbanas, empobrecimento dos atingidos e seu deslocamento para as periferias das cidades do entorno.

Em Nova Ponte a participação direta da população atingida na luta pela construção dessa nova cidade, com suas inovações e alterações em um exercício de democratização, ganhou um novo papel e novas funções no sentido da socialização nas decisões coletivas, através do surgimento de novos atores e da atuação destes na esfera pública. Aqui, as alterações nas políticas públicas e no plano da nova cidade induziram ao questionamento sobre qual seria o lugar da participação popular, as relações entre Estado e sociedade e entre os espaços públicos e privados, sobretudo no que diz respeito às diferentes formas de sociabilidade nas sociedades democráticas.

Foi através da possibilidade de representação e de negociação entre o Estado e a sociedade que se iniciou o processo de mudança cultural e política. Os espaços públicos e a memória construída, de um lado, e as referências simbólicas e sua preservação, de outro, vão constituir os elos de solidariedade entre os moradores de Nova Ponte.

A representação política e a participação da sociedade, em uma ação responsável e compartilhada nos projetos urbanos, poderão legitimar os novos espaços locais participativos e garantir o direito à acessibilidade aos bens coletivos urbanos e melhores condições de vida. Estão vinculadas à constituição de identidades em diferentes espaços públicos, as ações

${ }^{65}$ NAVARRO (1996). 
individuais ou coletivas, que tenderiam à individualidade em sua heterogeneidade de formas, e as comunidades locais e as associações de bairro, que podem ser portadoras de uma "ancoragem" territorial mais significativa para os projetos urbanos. ${ }^{66}$

Em Nova Ponte a sociedade civil mostrou-se ativa na articulação e construção de espaços públicos para interlocução com o poder político local. No processo de constituição de sujeitos individuais e coletivos, os cidadãos atuaram de forma direta ou através de mecanismos, como as associações de bairros. O processo envolveu critérios de julgamento e elementos de decisão com controle e possibilidade de revisão pelos cidadãos ${ }^{67}$.

Os espaços públicos seriam os espaços destinados à formação de opinião, formulação de proposições, tematização de questões que interessam a todos, o "locus" de negociação entre os atores e também o lugar da visibilidade. A sociedade civil participou, procurou levantar informações junto a CEMIG, formulou questões em defesa de seus interesses e levou essas questões a público com a finalidade de formar consensos e criar parâmetros de decisão.

No início do processo, apesar de sua precária sistematização e reduzida visibilidade, as organizações populares conseguiram assumir funções estratégicas e, posteriormente mantiveram o seu controle. Essas funções assumidas só obtiveram resultados relevantes no processo de transferência da população de Nova Ponte para um novo "lugar", pela dimensão expressiva da participação alcançada, não só em termos de construção de identidade, recuperação e definição de valores, mas por ter produzido algum impacto sobre o poder político regional e estadual.

Os dados mostraram o fortalecimento da sociedade civil local com uma atuação sistemática e coordenada. Mas, sempre houve o risco da manipulação,

\footnotetext{
${ }^{66}$ PEREIRA (1999).

${ }^{67}$ A participação pode se constituir como instrumento de controle social e político e entendido no sentido positivo é dar possibilidade aos cidadãos definirem critérios e parâmetros para orientar a ação pública e seu campo de ação é o espaço público, onde os diversos atores "aparecem", se fazem presentes, para "serem vistos e ouvidos por todos", manifestam-se pela ação e pelo discurso (ARENDT, 1981).
} 
do fortalecimento das próprias elites e das políticas adotadas, pela legitimação dos projetos e mecanismos constituídos. Para se prevenir desses riscos, as organizações adquiriram visibilidade e perante a sociedade como um todo, criaram espaços públicos autônomos nos quais essas políticas e projetos foram discutidos (TEIXEIRA, 1998).

Em Nova Ponte, a partir de práticas reivindicatórias, os cidadãos construíram coletivamente perspectivas de futuro e encontraram canais para lutar pela realização de seus projetos de vida antes confinados à esfera da vida privada. A perspectiva de poder intervir na definição de seu próprio destino libera energias para a participação e para a constituição dos movimentos sociais $^{68}$. No momento em que a CEMIG desconsiderou as reivindicações apresentadas pelo segmento social atingido, a sociedade acumulou e sociabilizou estas experiências, o que a levou para o caminho da mobilização e para a conquista de espaços que adquiriram uma dimensão coletiva, da solidariedade, da cultura e da participação nas decisões que incidiram sobre suas vidas.

Velhos artigos de jornais da região registraram que na década de 30 já havia um estudo do governo federal para o aproveitamento do rio Araguari, no Triângulo Mineiro, como fonte de energia e se discutia a transferência da cidade de Nova Ponte para um local mais alto. Mas apenas em 1964 foi elaborado o estudo para se verificar a viabilidade da construção de uma usina hidrelétrica no local. A CEMIG e a Conambra Engineering Consultan desenvolveram um projeto para averiguar as possibilidades técnicas da implantação da UHE Nova Ponte. A Hidro Service foi responsável pelos estudos de viabilidade técnico-econômica do empreendimento, cujo contrato só foi assinado com a CEMIG em 1970. A concessão para a construção da usina foi outorgada pelo Governo Federal a CEMIG através do decreto $n^{\circ} 76.006$, de 23 de julho de 1975.

Em agosto de 1982, o projeto básico da UHE Nova Ponte foi iniciado. Nesse momento, teve início um jogo que decidiria o destino da cidade de Nova Ponte. Em 1993, para produzir energia, o nível dos rios Araguari e Quebra-

${ }^{68}$ BAVA (1983). 
anzol foi elevado em 100 metros, inundando uma área de 445 quilômetros quadrados, inclusive a velha cidade. A represa ao atingir seu nível máximo deixou a parte mais baixa da cidade a 80 metros de profundidade e toda a cidade desapareceu.

$\mathrm{Na}$ instalação da usina, além dos gastos, que somaram aproximadamente US\$500 milhões, não incluindo juros e obras relativas à linha de transmissão, o custo da obra para a relocação e construção da nova cidade girou em torno de US\$ 60 milhões, e foram gastos, ainda, US\$160 milhões com indenizações na área rural e a relocação e construção de pontes e estradas. Os recursos vieram do Banco Nacional do Desenvolvimento Econômico e Social - BNDES, da ELETROBRAS e do Banco Interamericano de Desenvolvimento -BID.

A maior preocupação da população local foi a relocação da cidade. A idéia era reconstruir Nova Ponte, mas uma nova cidade com a participação da população discutindo os assuntos pertinentes, o que se contrapunha à atuação da CEMIG. Naquele período, a empresa era avessa a esses procedimentos e sua linha de atuação objetivava prioritariamente minimizar os custos de implantação do setor.

A CEMIG tornou-se a proprietária ${ }^{69}$ de Nova Ponte, era a empresa responsável pelos relacionamentos institucionais com outros organismos estatais e pela futura operação das instalações. Seus técnicos chegavam e se consideravam os "donos da cidade". A prepotência, o autoritarismo e a tecnocracia estatal eram questões recorrentes no tratamento dado aos atingidos, não só em Nova Ponte, mas era a prática usual do setor elétrico. Diante dessa situação, alguns moradores contestavam e outros ficavam apreensivos. Helder Naves Torres, em entrevista, relata: "Minha própria tia e minha avó, que ainda era viva, ficavam morrendo de medo da CEMIG tomar a casa e não dar nada, pra que você visse a prepotência que tinham os técnicos

69 A empresa proprietária, uma empresa pública, comanda o projeto em suas fases preliminares, organiza licitações, promove arranjos técnicos e financeiros para iniciar as obras. O proprietário é responsável pelos relacionamentos institucionais com outros organismos estatais e pela futura operação das instalações, é a face pública mais visível do projeto (RIBEIRO, 1991, p.44). 
e engenheiros que vinham achando que eram os donos de tudo. Eu sabia tudo sobre licenciamento ambiental e chegava, para os caras, de igual para igual. Dizia para as pessoas: tem que fazer denúncia junto à câmara técnica! Então a CEMIG começou a tomar mais cuidado."

Uma inovação no campo jurídico para o tratamento dos segmentos sociais atingidos na construção da UHE Nova Ponte foi a obrigatoriedade de um estudo executado pela CEMIG, exigido pelo órgão ambiental responsável COPAM. O estudo registrou o levantamento histórico e a memória da cidade de Nova Ponte, incluiu a arquitetura, a história, o urbanismo, a ocupação, a história da ocupação, o cotidiano, os modos de ocupação do lugar.

O advogado, Dr. Luiz Fernando Abreu, foi uma figura importante no processo, como conta D. Aparecida: "O Dr. Luiz Fernando foi muito importante para Nova Ponte, ele é advogado da procuração da CEMIG, ele chorava junto com a gente, ele sentia como a gente sentia, ele se preocupava com o bem estar da população de Nova Ponte. Ele ligou em Belo Horizonte e disse queria a escola de arquitetura aqui. E a escola veio para cá".

O processo de mudança, da velha para a nova cidade, incidiu sobre os modos de ocupação e apropriação do espaço, sobre o os valores e representações vinculados ao local, atingindo a dinâmica das relações sociais e econômicas, introduzindo modificações na formação social do local, nos aspectos culturais e subjetivos dos grupos sociais, colocando em confronto um conjunto de interesses reivindicados e negociados entre os diversos atores envolvidos: engenheiros da empresa elétrica, técnicos, consultores, planejadores, representantes de entidades de classe, moradores, políticos etc $^{70}$.

Na construção da UHE de Nova Ponte, foram identificados os seguintes atores institucionais diretamente envolvidos: a CEMIG, empresa estatal e proprietária, responsável pelos relacionamentos institucionais, a face pública

\footnotetext{
70 Todas essas forças sociais "não estão dadas a priori, mas se constituem no próprio processo, a partir da estrutura social preexistente, da lógica de atuação do Estado, que varia historicamente, e também das alianças construídas e desfeitas ao longo do processo de realocação" (SIGAUD, 1986).
} 
mais visível do projeto; a LEME engenharia, sediada em Belo Horizonte - MG, empresa consultora, responsável pelo planejamento e supervisão da obra, com objetivos exclusivamente técnicos e pessoal altamente qualificado, com atuação menos visível que a dos outros atores envolvidos; o consórcio, das construtoras Andrade Gutierrez e Camargo Corrêa cumprindo contrato para execução das principais obras civis, foi o maior empregador do projeto e com maior visibilidade pública através dos grandes recursos que administraram. $O$ contrato firmado entre a CEMIG e o consórcio das construtoras tinha o valor nominal de $\mathrm{Cz} \$ 2.950$ bilhões destinados para a execução das obras civis da UHE Nova Ponte, com prazo para a entrada em operação até 1992. Estas obras civis também contaram com recursos financiados pela ELETROBRAS e desembolso do caixa da própria CEMIG. Segundo Eduardo Andrade, diretor superintendente da Construtora Andrade Gutierrez, o consórcio investiu Cz $\$ 1,3$ bilhão em equipamentos e capital de giro para a execução das obras de Nova Ponte. Destacou ainda que o consórcio formado pelas duas empresas empregou no canteiro de Nova Ponte cerca de 2.500 pessoas.

Os atores internacionais foram representados pelo Banco Mundial - BM, esse banco opera através de licitações internacionais vinculando o projeto ao capital internacional, e pelo Banco Interamericano de Desenvolvimento - $\mathrm{BID}^{71}$, que financiou parte dos equipamentos através de negociação via BNDES.

Teoricamente, como atores indiretos, foram identificados: o Ministério Público Federal que é responsável pela proteção do patrimônio público e social, do meio ambiente e de outros interesses difusos e coletivos; a Secretaria de Segurança Pública, canal para denúncias públicas; o Poder Judiciário, mediador dos conflitos; a Igreja Católica; a Universidade Federal de Minas Gerais - UFMG ${ }^{72}$; os proprietários rurais atingidos; as Prefeituras com

\footnotetext{
71 "O grau de nacionalização vê-se reduzido pela ação das empresas e bancos internacionais, tornando-se duvidoso o verdadeiro sentido do desenvolvimento: para o país ou para o exterior? A resposta pode ser encontrada no caráter ideológico do desenvolvimentismo, que não visa promover o desenvolvimento, mas tão-somente a acumulação de capital" (FROELICH, 2001).

${ }^{72}$ A Universidade Federal de Minas Gerais foi contratada para fazer o levantamento da história e da memória da cidade de Nova Ponte, desde a sua fundação. Este trabalho foi concluído e entregue para a população e tem seus originais cuidadosamente arquivados no Arquivo Público de Nova Ponte, o "chalezinho" como é conhecido.
} 
áreas alagadas; e a população urbana da cidade de Nova Ponte.

Em Nova Ponte, o maior problema apontado pelas autoridades, líderes comunitários e proprietários rurais, foi a negociação e o pagamento de indenizações pela CEMIG aos proprietários de imóveis em áreas inundáveis. Em 1986, na tentativa de se obter preços justos para as terras na região que foram alagadas, as lideranças regionais fundaram o Sindicato Rural de Nova Ponte e a ARPA - Associação de Prefeituras, Proprietários Rurais e Sindicatos dos Vales dos rios Araguari e Quebra-anzol, para negociar com a CEMIG.

Os proprietários e meeiros - agricultores que cultivam em terras alheias da região afetada, em reuniões com a ARPA e a CEMIG, sinalizaram em sua maioria que não pensavam em dispor de seus bens e se sentiam obrigados a abandonar suas propriedades para a construção da usina. Questões como essas foram levadas para as reuniões com a CEMIG e a ARPA, na tentativa de sensibilizar os representantes da empresa e os líderes políticos regionais para alguns dos problemas enfrentados pela população local.

A CEMIG insistia nas negociações individualizadas, qualificando-as como democráticas, mas o objetivo das associações formadas era fazer com que todas as negociações acontecessem em conjunto. Ainda em 1986, para dar mais transparência e essas negociações outra comissão foi formada, a AMPLA - Associação dos Municípios da Microrregião do Planalto de Araxá. O medo dos atingidos em Nova Ponte era a violência na expropriação que poderia ter sido maior na região como aconteceu em Emborcação, onde o pequeno produtor hoje é bóia-fria. Essa foi uma questão judicial de maior importância, que foi tratada de maneira especial buscando uma ação governamental que não fosse individualizada, que objetivasse a inclusão dessas dimensões no âmbito do bem coletivo, o bem comum.

A população de Nova Ponte viveu momentos de angústia e incerteza com a chegada dos primeiros técnicos e empresas contratadas pela estatal. Num primeiro momento, a população local saudou a obra como sinal de mudança e modernidade positivas. Mas em pouco tempo, principalmente pela falta de informação, a população entrou em pânico. Segundo Helder Naves 
Torres: "Por medo, muitos moradores venderam suas casas por preços inferiores ao mercado e, com isso, não conseguiram comprar moradias em outras cidades próximas, voltando depois à cidade natal em situação pior que antes. O ônus social do empreendimento não foi devidamente considerado pela CEMIG e a desagregação familiar e histórica acontecida foi fruto de decisões políticas de cima para baixo. Muitos técnicos que ali trabalhavam perceberam isso e nada puderam fazer em contrário, mesmo que não concordassem. Apesar de bem intencionados, eles obedeciam a ordens".

Em 1988, tem início na cidade de Nova Ponte um movimento liderado pelo Pe. José Lourenço Júnior - pároco no município de 1986-1992, culminando com a criação da Associação dos Moradores de Nova Ponte AMNP. Relata o Pe. Júnior: "Eu cheguei em Nova Ponte no dia dois de fevereiro de 1986. Em abril, percebi que a população estava sofrendo uma determinada pressão pela CEMIG, pelo fato deles terem que vender suas casas. Já tinham vendido as melhores casas para se tornarem os escritórios da CEMIG. Dava para ver claramente que aquilo era uma forma da CEMIG cercar a cidade com escritórios, que depois de cercada daria as cartas sozinha. Havia na comunidade cerca de 2.600 habitantes e 50\% desses proprietários estavam vendendo suas casas para a CEMIG. Foi quando formamos uma equipe, uma comissão para saber se o povo sabia o que realmente estava acontecendo".

A comissão elaborou um questionário ${ }^{73}$ com 21 questões; depois se dividiu em equipes de três pessoas sob a coordenação do pároco, e foram de casa em casa para aplicá-lo. Também instalaram urnas nas escolas, na prefeitura e nas repartições públicas, a fim de alcançar toda a população com a pesquisa. Entre as perguntas, estavam: O que é inundação? O que significa a palavra permuta? E o que é indenização? O resultado dessa pesquisa, apurada pelos próprios membros da comissão, foi que $97 \%$ da população não sabiam o significado da palavra permuta e muito menos o que seria indenização. A população pesquisada sabia que estava sendo construída a barragem, mas nem todos acreditavam na inundação da cidade. Diante desse quadro, a

\footnotetext{
${ }^{73}$ Segundo os entrevistados o questionário elaborado e aplicado pela comissão do Pe.Júnior desapareceu, juntamente com a ata das reuniões da AMNP. Apenas três questões foram recuperadas através de testemunho oral do pároco.
} 
comissão decidiu fazer uma grande assembléia, reunindo as lideranças da cidade, prefeito, presidentes de partidos, vereadores, etc. Essa primeira assembléia aconteceu na Igreja Católica da cidade, quando começaram a pensar na formação de uma associação, a AMNP - Associação dos Moradores de Nova Ponte, que surgiu neste mesmo ano e teve sua sede jurídica na antiga Nova Ponte. A associação achou necessária a união dos "afogados" 74 para obtenção de maiores informações e uma justa indenização. Segundo Pe. Júnior: "Em junho ou julho de 86, através dessa associação, iniciamos o trabalho de diálogo com a CEMIG. A primeira coisa que encontramos foi uma pressão muito grande por parte da CEMIG... que tinha acabado de executar a obra da usina de São Simão em Goiás, onde também construiu uma cidade: a cidade de São Simão. Nós imediatamente fomos a São Simão para vermos como era a construção das casas. Fomos, a comissão foi. Chegando lá, nos decepcionamos. As casas eram de pré-moldado, a casa parecia praticamente de papelão. Voltamos ainda mais conscientes, não queríamos aquele tipo de casa, aquele tipo de cidade, uma cidade de pré-moldado, uma cidade que parecia um conjunto de casas de bonecas, onde tudo era igual, onde ninguém teve a possibilidade de construir sua própria casa de acordo com sua vontade, seu sonho. Vimos claramente a invasão na vida daquele povo, uma agressão dentro da caminhada deles. É a mesma coisa que eu entrar na sua casa e dizer: a partir de hoje esta casa é minha! E me apossar da casa. A CEMIG usou mais ou menos esse critério. Estamos falando da CEMIG e não do funcionário da CEMIG, falamos de todo um sistema. Então pedimos uma reunião com todos os representantes da CEMIG local e da secretaria de Belo Horizonte. Mandaram um advogado para fazer pressão, que procurou a liderança da associação, que já estava formada, e disse: 'aqui quem manda somos nós, o governo vai fazer assim, e se vocês quiserem vai ser assim!' Tomamos a decisão naquele momento que não seria como eles queriam".

A barragem já estava com $50 \%$ de sua construção concluída e ainda se discutia a construção da cidade nova; não havia viabilidade financeira, segundo declarações dos funcionários da CEMIG, e seria mais fácil indenizar as famílias

\footnotetext{
74 "Afogados" foi como os próprios atingidos pela construção da UHE Nova Ponte se definiram. Desde ponto é vista é possível considerar os afogados como uma categoria nativa, tal como a denominaria a pesquisa antropológica.
} 
e mandá-las para cidades próximas como Uberaba e Uberlândia. Continua o Padre: "A primeira coisa que fizemos, então, foi reunirmos a comunidade, fizemos uma grande assembléia, abrimos mais o leque para a participação dos prefeitos, dos vereadores e as autoridades de outros municípios que também seriam inundados com a construção da barragem. A partir daí a coisa melhorou! As reuniões passaram a ser nas prefeituras de toda a região, com todas as lideranças e a nossa associação. A coisa tomou corpo. Quando já tínhamos o terreno da cidade, começamos a lutar para que nos mostrassem como seria o projeto da cidade."

A facilidade com que o padre veio a se tornar liderança em Nova Ponte pode ser explicada pela proximidade com a população. Em pequenas cidades do interior praticamente todos vão à missa aos domingos, esse foi um dos elementos facilitadores dessa representação, relata o próprio Pe. Júnior: "O padre tornou liderança porque tinha a facilidade de todos os dias estar com o povo, eu aproveitava desse momento para fazer nova conscientização, o que deu muito certo até mesmo com a participação de outras igrejas, que também começaram a fazer conscientização, como a Assembléia de Deus, centros espíritas e o candomblé. Todos começaram a se unificar, todas as seitas, todo mundo estava trabalhando pelo mesmo processo".

Sobre a associação, relata Leonel Brizola Pontes, Presidente da Associação: "Foram colocadas nessa Associação o prefeito, o vice-prefeito, os nove vereadores, o presidente do Sindicato Rural, o presidente da Cooperativa Mista do Cerrado, os representantes de todos os partidos políticos, dois representantes de cada bairro, somando ao todo 33 representantes, incluindo ainda os da área industrial e da igreja (o Pe. Júnior e os pastores da Congregação Cristã do Brasil, da Assembléia de Deus e da lgreja do Evangelho Quadrangular)".

Com a publicação da Lei Orgânica Municipal, em 12 de novembro de 1990, a AMNP passa a ter sua legitimidade reconhecida: "A Associação dos Moradores de Nova Ponte, possuidora de amplos poderes, à qual fazem parte o Legislativo, o Executivo e a Comunidade, está apta a oficializar e concretizar 
todas as negociações inerentes a relocação da atual cidade de Nova Ponte". ${ }^{75}$ Participando de negociações com a CEMIG, junto à Prefeitura e à Câmara Municipal, a Associação intervêm em questões urbanas, na construção da nova sede municipal e na negociação com os proprietários da antiga, responsabilizando-se diretamente pela distribuição dos lotes para a população: "Nosso acordo com a CEMIG foi que a gente fosse responsável pela distribuição dos lotes. Mudar uma cidade não é fácil... Nós fizemos 105 reuniões. Primeiro com um mapa da cidade velha, nós fizemos uma prédistribuição. Era complicado. A quadra 39, por exemplo, tinha 150 imóveis. Como mudar isso para uma quadra de 20 imóveis? Nós consideramos que vizinho é aquele que mora ao lado. A gente teve a preocupação de destacar o comércio das outras casas, localizando-os nas esquinas. Os moradores nós tentamos deixar nos respectivos bairros. Então você entra na velha cidade e olha: O primeiro à direita é o bairro São Francisco; o primeiro à esquerda é o Rosário; no centro está o centro (São Miguel); e atrás, o São Sebastião e o São João. A estrutura da cidade a gente manteve" (Figura. 34). (Leonel Brizola Pontes - Presidente da Associação).

Segundo Pe. Júnior: "Tivemos mais de um jornal. Os jornais até foram muito importantes, um era um pouco tendencioso no início, pois a verba vinha do governo municipal e divulgavam questões da obra, sua apresentação, etc. Depois saiu o jornal do professor lozaino ${ }^{76}$, professor de história".

Os jornais surgiram da necessidade de divulgação dos acontecimentos e problemas da cidade, como forma de veiculação, preservação e difusão das concepções culturais da população de Nova Ponte.

A mídia teve um papel importante no conflito. Num primeiro momento, houve um jogo de forças onde o lado dos interesses e o poder econômico da CEMIG conseguiu aglutinar os meios de comunicação, os políticos regionais e legitimar a idéia do progresso da região e do país com a construção da usina hidrelétrica. Em um segundo momento, os "afogados", organizados em associações, buscaram na opinião pública o respaldo para suas reivindicações

\footnotetext{
${ }_{76}^{75}$ Ato das Disposições Constitucionais Transitórias, artigo 18.

${ }^{76}$ Jornal Ação Notícias do Professor lozaino José Carneiro.
} 
e a manutenção de informações sobre as negociações e o processo de reassentamento da população atingida ${ }^{77}$.

Segundo LITTLE (2001), todos os atores sociais envolvidos em conflitos sócio-ambientais se utilizam destes símbolos e imagens para promover seus próprios interesses. Os conflitos sócio-ambientais possuem base material e contém disputas de sentido e discursivo, na tentativa de geração de opinião pública favorável, o que se transformam em um novo campo de luta para estes mesmos conflitos.

Um momento muito alardeado por toda imprensa local, inclusive sendo exibido pela TV Globo local, além dos jornais escritos regionais, foi quando a comissão, sob a coordenação do Pe. Júnior, resolveu se mobilizar para paralisar as obras da barragem e iniciou o "Movimento SOS Nova Ponte - não deixe Nova Ponte desaparecer, a cidade dos afogados precisa vencer". Segundo Pe. Júnior: "Era nosso grito de guerra, então isso foi importante, pois chamou a atenção".

A idéia partiu do jornalista Marco Rocha, que também ajudou na paralisação, relata o padre: "Eu subi num guindaste que fica a quase 300 metros acima da terra, para paralisamos a obra. Não entrava e não saia ninguém da cidade, enquanto não fossemos ouvidos pelas autoridades da CEMIG. Eu nunca fiquei tão alto na minha vida! $E$ o que aconteceu? Duas horas depois, mandaram o presidente da CEMIG. E nós juntamente com a população, prendemos o presidente da CEMIG dentro da igreja. Chamamos os prefeitos, vereadores e alguns deputados. Falamos abertamente o que queríamos. E logo depois expulsamos o presidente da CEMIG da cidade. Não de uma maneira simbólica, mas real, com uma grande movimentação. Depois de dizermos tudo o que ele deveria ouvir. Aquele foi um momento chave. Ele percebeu que a população não estava brincando e também o impacto na região. Estavam ali, prefeitos, vereadores e também deputado estadual e federal. O presidente da CEMIG saiu indignado. Jamais poderia imaginar que

\footnotetext{
${ }^{77}$ Nos últimos trinta anos houve um crescimento do setor informático e da "mass média" no cenário político brasileiro. A geração e o controle de informação e conhecimento passaram a servir como fonte de poder e neste contexto, os símbolos e imagens são cobertos de importância tornando-se parte do domínio e dos conflitos públicos (LITTLE, 2001, p.118).
} 
seria expulso da cidade e vaiado. Ele só voltou à Nova Ponte com uma resposta positiva sobre o que queríamos: o início imediato das obras da cidade nova. Trinta dias depois, estavam começando as obras da cidade."

O manifesto S. O. S. Nova Ponte ${ }^{78}$, que foi publicado em 91, teve o objetivo de tornar pública a situação de paralisação das obras da nova cidade que tiveram início em 87. Um jornal local denunciou o atraso das obras e a paralisação da hidrelétrica em artigo intitulado: "Hidrelétrica de Nova Ponte será adiada ainda mais" ${ }^{79}$. Em meio a denúncias de cartel e "calote" da CEMIG $^{80}$ durante as licitações e a obra, a ELETROBRAS recuou no financiamento para a UHE - Nova Ponte. Apenas com a mudança de governo do Estado em 1992, na gestão do governador Hélio Garcia, foram retomadas as negociações com o governo federal para a liberação dos recursos necessários e dar continuidade às obras. A CEMIG iniciava um processo de saneamento financeiro. O cronograma foi alterado e o fechamento dos túneis foi marcado para setembro de 1993, com a entrada em operação comercial da primeira turbina em abril de 1994. O manifesto que segue na íntegra deixa clara a indignação da população.

\section{"SOS NOVA PONTE}

A CEMIG alega não ter dinheiro para construir a nova cidade, mas a barragem continua a crescer, e ainda iniciaram outras construções (usinas de Miranda, Capim Branco, etc.), além disso, há um gasto excessivo com o número de carros para engenheiros marajás. SERÁ QUE ISSO TUDO É DE GRAÇA? E O POVO DE NOVA PONTE? É APENAS UM DETALHE COMO DIZIA A EX - MINISTRA ZÉLIA?

A CEMIG não cumpre seus compromissos: a cidade nova deveria estar quase pronta, no entanto, está paralisada. Eles estão esperando o fechamento das comportas para negociarem como querem, isto é, causando prejuízos enormes a toda a população. HEIN, CEMIG? QUE VERGONHA!

A dengue em NOVA PONTE, provavelmente veio com os barrageiros. A cólera e a AIDS poderão chegar aqui através dos mesmos. SERÁ QUE JÁ NÃO BASTA UMA

\footnotetext{
${ }_{78}^{78}$ A Boca do Povo, s.d.

79 Jornal das Gerais, 04/05/91.

80 Jornal Tribuna Mineira, s.d. e Jornal Minas Gerais / Interior e Grande BH, 19 de julho de 1988.
} 
DESGRAÇA CHAMADA CEMIG? ISTO É O PROGRESSO QUE A CEMIG TANTO FALA E PROMETE?

A construção da vila residencial (obra faraônica) foi um gasto desnecessário e irresponsável por parte da CEMIG e do governo, fato que contribuiu em partes para a não - construção da cidade nova, para a falência da MINAS CAIXA e a miséria do povo. QUE MARACUTAIA, HEIN? QUE BAIXARIA, HEIN?

A construção da barragem vem provocando inundações: a ponte foi danificada, áreas de lavouras, hortaliças e pastagens foram perdidas e, após as inundações, há um acúmulo de areia e barro nas margens do rio, provocando o mau cheiro e até doenças na população ribeirinha. ESTE É O PROGRESSO QUE VEIO PARA NOVA PONTE? VERGONHA, HEIN, CEMIG!

A CEMIG assinou um documento com a associação dos moradores de NOVA PONTE entidade que representa os anseios do nosso povo, para viabilizar, num prazo assumido pela mesma, a construção da nova cidade de NOVA PONTE, ONDE ESTA O COMPROMISSO ASSUMIDO, CEMIG?

As rachaduras das casas e prédios, devido às explosões para desviar o rio, causaram prejuízos enormes à população. Ninguém pode restaurar suas casas. Estas explorações e a movimentação constante (dia e noite) de veículos pesados, além de afetarem a infra - estrutura da cidade, provoca uma poluição sonora acima dos limites. DE QUEM É A RESPONSABILIDADE HEIN, CEMIG?

A construção da barragem em Nova Ponte provocará futuramente a inundação das melhores terras de vários municípios da região. Tal fato provocará uma queda considerável na produção agrícola e pastoral. CEMIG INDENIZARÁ ESTAS TERRAS A PREÇO DE BANANA MADURA, COMO JÁ ACONTECEU? RESPONDA, CEMIG?

CEMIG é hoje em nossa região, a maior depredadora do meio ambiente: os peixes são impedidos de subirem o rio, quebrando assim, o ciclo de reprodução; a fauna terrestre é obrigada a migrar para outras regiões, e o que pode provocar até a extinção de algumas espécies; a vegetação ribeirinha e as áreas onde as máquinas retiram cascalho, terra, etc. já foram destruídas.

Tais fatos e muitos outros, vêm contribuindo para mudanças bruscas no sistema ecológico. ISTO É PRESERVAR O MEIO AMBIENTE? ESTA É MAIS OBRA DA CEMIG!" 
O Movimento S. O. S. Nova Ponte contou com o apoio de grande parte da opinião pública e pôde ser beneficiado por esta reserva de apoio para levar adiante suas iniciativas. Com o caráter de mobilização coletiva, a formulação do movimento S. O. S. Nova Ponte e a mobilização popular organizada em torno de um interesse comum tornou possível o próprio movimento, que foi se configurando e adquirindo identidade através de práticas concretas de ação.

Definido como movimento social, por ser uma forma específica de mobilização, com espaço próprio e diverso do espaço ocupado por partidos e sindicatos, estabeleceu uma nova relação com o político fazendo parte de uma sociabilidade que deixa de ser "feita" para ser "vivida" ${ }^{81}$. Nesse momento, o registro político desses sujeitos sociais se localiza na própria reinvenção de direitos, segundo SILVA (1996) desde a legitimação das reivindicações à conquista dos direitos e a sua permanente reformulação, o que sobressai é a construção de uma história que continua aberta.

Sob a ótica da CEMIG, não haveria porque alterar a postura convencional de buscar a liberação da área requerida para a construção da usina ao menor custo e em prazo compatível com o cronograma da obra. A negociação entre a empresa e os segmentos sociais atingidos se dava tradicionalmente apenas com base nos direitos de propriedade, através da jurisprudência dominante que estabelecia apenas o ressarcimento financeiro aos prejuízos passíveis de indenização, ou seja, para os atingidos restava apenas a cobertura aos danos à propriedade por encontrarem respaldo legal:

Dentro das regras do jogo então prevalecentes, a consideração, no processo decisório relativo aos aproveitamentos hidrelétricos, de quaisquer interesses, individuais ou coletivos, não redutíveis a danos patrimoniais respaldados em lei dependia, de um lado, da capacidade de mobilização e pressão política em defesa dos mesmos e, de outro, das concessões que a empresa empreendedora se vê constrangida e está disposta a fazer enquanto responsável pelo projeto. $\mathrm{Na}$ ausência de mecanismos de intermediação de interesse minimamente estruturados para lidar com a questão,

${ }^{81}$ EVERS (1983). 
os resultados do processo tendem a ser fortemente viesados no sentido da prevalência da lógica decisória da empresa, de minimização do custo de implantação do empreendimento (CARNEIRO, 2000, p.251).

A construção da UHE Nova Ponte teve grande importância para a CEMIG e para o sistema energético não só da região sudeste, porque possibilitou a execução de mais dois projetos hidrelétricos - Miranda e Capim Branco, ambas da CEMIG -, mas o seu reservatório beneficiou todas as usinas a jusante, incluindo as localizadas no rio Paranaíba, como as usinas de llha Solteira, Jupiá, Porto Primavera, Ilha Grande e Itaipu ${ }^{82}$. A construção da usina de Nova Ponte marcou a retomada da CEMIG como uma empresa construtora de grandes barragens. A última hidrelétrica construída pela CEMIG foi Emborcação, inaugurada em fevereiro de 1983. A partir de 1983, a CEMIG registrou um decréscimo em seus índices econômicos refletindo a recessão que o país atravessava. Uma reação econômica da empresa pôde ser notada em 1985 e $1986^{83}$.

Em 23 de junho de 1987, a CEMIG iniciou oficialmente as obras da nova cidade de Nova Ponte com o lançamento da pedra fundamental ${ }^{84}$ da futura cidade. A solenidade, presidida pelo então governador Newton Cardoso contou com a presença do presidente da CEMIG Paulo Pedro de Almeida Cezarini e seus diretores, o secretário de Minas e Energia Geraldo Paulino Santana, dos Transportes José da Conceição, da Cultura Ângela Gutierrez, além de deputados, lideranças políticas e prefeitos da região. O evento contou com ampla cobertura da imprensa local e regional, e também com a presença da grande maioria dos moradores de Nova Ponte.

Cerca de duas mil pessoas aguardaram o governador e sua comitiva no local onde hoje está a Praça da Igreja de São Miguel. Apesar do forte esquema de segurança, com aproximadamente setenta policiais militares da cidade de Uberlândia, a visita do governador transcorreu sem problemas ou

\footnotetext{
82 CEMIG Notícias (novembro/1987).

83 Tribuna Mineira s.d.

${ }^{84} \mathrm{O}$ marco da nova cidade é um bloco de pedra oriundo da cachoeira do Salto, no rio Araguari, de origem sedimentar e muito antiga, segundo o jornal Estado de Minas (02/07/87).
} 
constrangimentos. Em seu discurso, Newton Cardoso afirmou: "Sem promessas, eu trago para esta cidade empregos e a garantia de progresso constante".

O discurso enfatizou que a usina de Nova Ponte iria garantir a energia necessária para o crescimento de Minas Gerais, evitaria que o Estado sofresse com algum racionamento de energia semelhante ao que ocorreu no nordeste do país ${ }^{85}$.

Após descerrar a placa comemorativa do início das obras de Nova Ponte, o governador assinou um convênio com o Diretor do Departamento de Estradas de Rodagem (DER), Maurício Guedes de Melo, autorizando a pavimentação das rodovias MG-190, BR-146 e BR-452, além da rodovia Uberaba - Nova Ponte. O governador, referindo-se aos custos com a construção da usina e a relocação da cidade, destacou as concepções que norteavam seu governo: "No meu calendário não haverá um dia que não inaugurarei uma obra, e obras generosas como estas, orçadas em 500 milhões de dólares!".

Durante a solenidade de lançamento da pedra fundamental da cidade de Nova Ponte, o então presidente da CEMIG, Pedro Cezarini discursou sobre a obtenção dos recursos para as obras da CEMIG em todo o Estado, destacou o empréstimo levantado junto ao BID no valor de 123 milhões de dólares, para o financiamento de parte das obras de Nova Ponte, e concluiu: "Estamos com todos os compromissos em dia com os fornecedores e empregados. Temos procurado, na medida do possível, ampliar o diálogo com todos os segmentos da sociedade, sintonizando e abrindo a CEMIG para esta nova era, que temos a satisfação e a honra de participar. Esta é uma empresa em que não há protegidos e nem empreguismo. Aqui, o homem que é capaz, trabalhador e dedicado tem seu valor reconhecido e é prestigiado. (...) Em breve, vamos cumprir o prometido e entregar uma nova cidade ${ }^{86}$. (...) Esta, também, é uma prova cabal de que realmente a CEMIG vive um novo tempo, um tempo de

\footnotetext{
${ }^{85}$ CEMIG Notícias (julho/7987)

86 A primeira proposta da CEMIG foi transformar a vila operária em uma nova cidade para abrigar os expropriados de Nova Ponte.
} 
diálogo e de estreitamento de relações com a comunidade". ${ }^{87}$

Apesar dos discursos, apenas a pedra fundamental e um cruzeiro de madeira que foi carregado pelo povo da velha cidade de Nova Ponte foram plantados no solo onde foi erguida a nova cidade. Em 1991 as obras da cidade tiveram início e a CEMIG foi obrigada a respeitar a transferência da população com alguma estrutura digna para os moradores. Depois de muita luta a população de Nova Ponte garante o direito a um novo "lugar". Esta conquista só foi possível através da inserção de uma cláusula no processo de licenciamento ambiental, o que representou uma garantia jurídica para o destino de Nova Ponte. Na primeira solução encontrada pela CEMIG, os habitantes da cidade de Nova Ponte seriam transferidos para o acampamento dos barrageiros, hoje a vila, que corresponde a um bairro da nova cidade. Nesse reassentamento, as pessoas que não aceitassem o novo lugar ou as famílias que não mais coubessem na vila seriam indenizadas em dinheiro ${ }^{88}$.

O argumento jurídico que viabilizou a nova cidade e garantiu a conquista do direito à cidade aos cidadãos de Nova Ponte, foi inserido no licenciamento ambiental, documento obrigatório para a construção da UHE de Nova Ponte. A cláusula determinou que a CEMIG só poderia fechar as comportas para iniciar o enchimento do lago da barragem, após a emissão da Licença de Operação LO, geralmente, esta licença é concedida com as comportas fechadas. Esta foi uma grande conquista da população da cidade. Ficou firmado que a LO só seria emitida quando $99 \%$ das questões prioritárias exigidas no licenciamento ambiental estivessem cumpridas. O responsável foi o advogado Dr. Léo Pompeu Resende de Campos, na época da Comissão da Superintendência Executiva da COPAM - Comissão de Política Ambiental ${ }^{89}$.

Segundo Helder Naves Torres: "Quando mudou o governo - de 90 para 91 - o Newton Cardoso perdeu a eleição e o Hélio Garcia assumiu, a coisa melhorou um pouco, começou a haver mais diálogo".

\footnotetext{
${ }^{87}$ CEMIG Notícias (julho/1987).

${ }^{88}$ Entrevista com Helder Naves Torres.

89 Atual Conselho de Política Ambiental.
} 


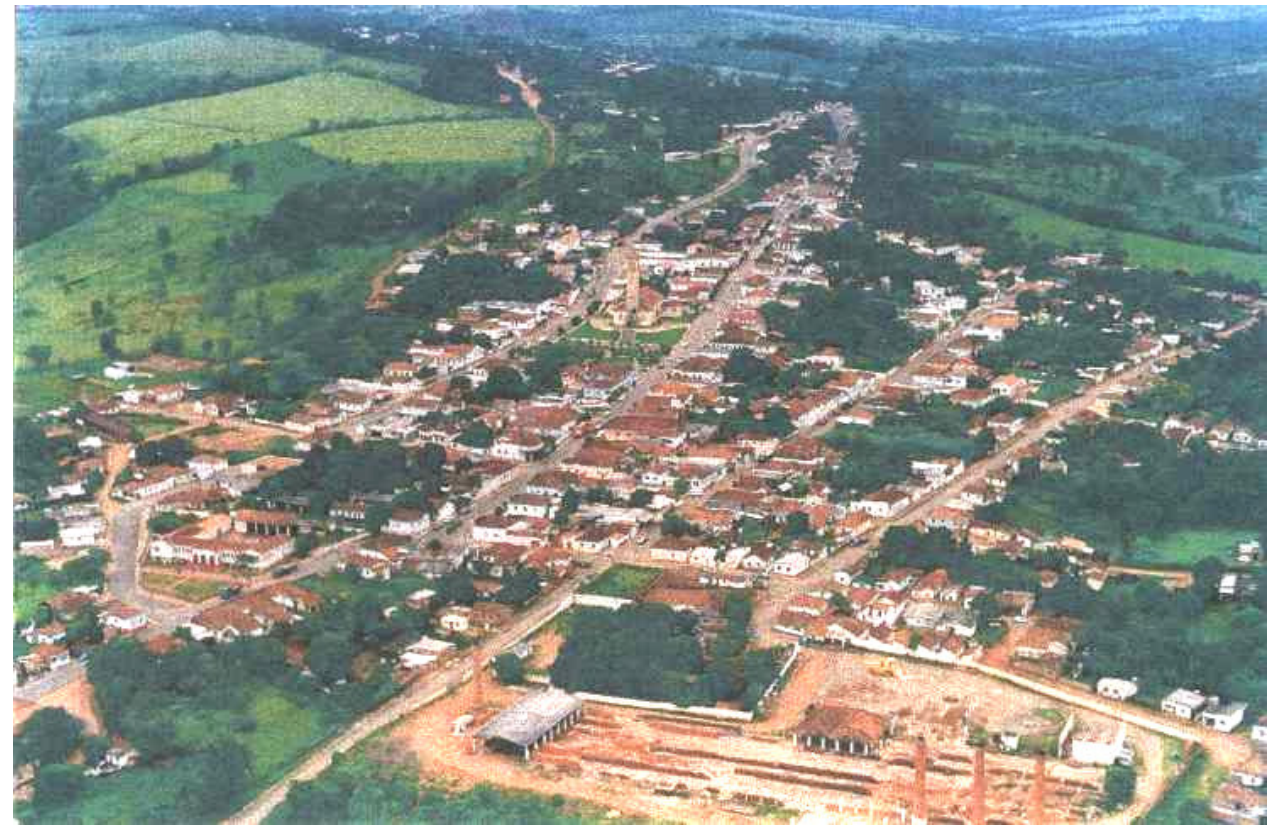

Figura. 33 - Foto aérea da cidade que desapareceu. Fonte: CEMIG - Belo Horizonte, s.d.

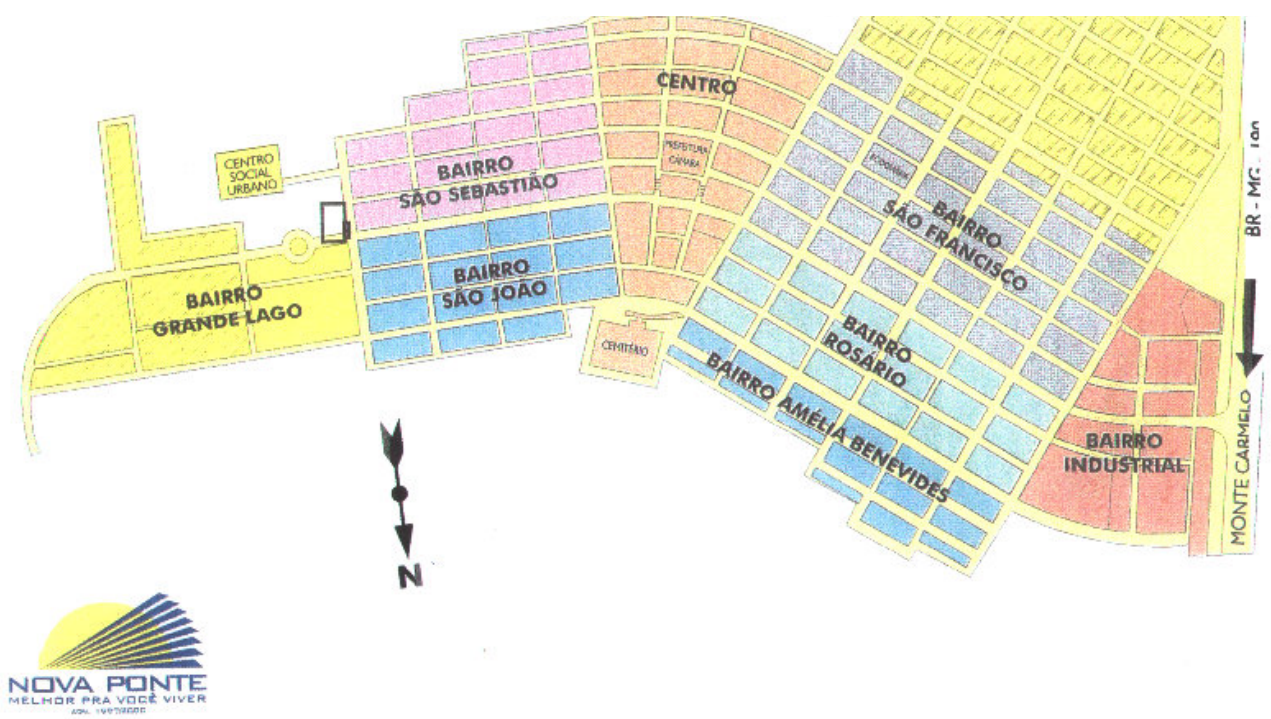

Figura. 34 - Mapa de localização dos bairros na nova cidade. Fonte: Prefeitura Municipal de Nova Ponte. 


\subsection{Um breve histórico da trajetória do setor elétrico brasileiro: o tratamento dos segmentos sociais afetados}

O elevado potencial hidráulico do Brasil fez do setor elétrico um "setorchave" para alavancar a industrialização e a acumulação de capital. As primeiras instalações hidrelétricas do país foram construídas a partir de 1884, todas no Estado de Minas Gerais: Ribeirão do Inferno, em Diamantina, foi construída em 1884 por Armand de Bovet; Ribeirão dos Macacos, em Nova Lima, foi construída em 1887; Marmelos, em Juiz de Fora, foi construída por Bernardo Mascarenhas ${ }^{90}$. Apenas neste período, final do século XIX, houve a participação do capital privado; o capital estrangeiro predominou de 1900 a 1930, e o capital estatal teve destaque no financiamento do setor elétrico de 1930 a 1945. No ano de 1934 foi aprovado o Código de Águas ${ }^{91}$, que estabeleceu:

A distinção entre a propriedade do solo e a propriedade das quedas d'água e outras fontes de energia hidráulica para efeito de exploração ou aproveitamento industrial. Ao caracterizar as quedas d'água como bens imóveis, distintos e não integrantes das terras em que se encontravam, para o regime das autorizações e concessões para os aproveitamentos hidrelétricos. O código postulou também, a nacionalização progressiva das quedas d'águas julgadas básicas ou essenciais à defesa econômica ou militar do país (ELETROBRAS, 1988, p.82-84).

O período de 1945-1964 pôde ser caracterizado pela maciça intervenção estatal e pela criação da ELETROBRAS - Centrais Elétricas Brasileiras S/A para a exploração do potencial hidrelétrico do país. No plano das idéias formaram-se duas correntes de pensamento desenvolvimentista no Brasil, os

\footnotetext{
${ }^{90}$ VARGAS (1994, p. 24).

${ }^{91}$ Decreto 26294 de 10/07/1934.
} 
nacionalistas-intervencionistas e os liberais-privatistas, que persistiram no pós - guerra:

No governo de Juscelino Kubitschek, no período 1951-1956, no Plano de Metas de Minas Gerais, elaborado pelo engenheiro Lucas Lopes, a componente energia elétrica destacou-se amplamente. O engenheiro criou em 1950, o Plano de Eletrificação e em 1952 tornou-se o primeiro presidente da recém-criada CEMIG - Centrais Elétricas de Minas Gerais. As maiores usinas sob responsabilidade da CEMIG tiveram seus projetos e construção a cargo de empresas estrangeiras (FROELICH, 2001, p.183).

A partir dos anos 60, a forte presença da CEMIG na elaboração dos projetos e na construção de grandes usinas propiciou maior conhecimento sobre a tecnologia empregada nestes empreendimentos. E com a apreensão deste conhecimento o planejamento e as obras puderam ser realizados por empresas nacionais.

Quanto ao setor elétrico, Juscelino Kubistchek (1956-1961) ${ }^{92}$, no governo federal, adotou o modelo mineiro que criara enquanto governador de Minas Gerais. Nesse momento o setor elétrico recebeu, pelo governo federal, maior destaque do que no período Vargas. Foi criado o Ministério das Minas e Energia em 22/07/1960, pela lei 3782, incorporando o CNAEE - Conselho Nacional de Águas e Energia Elétrica. Mas, apesar do avanço do planejamento energético, o projeto da ELETROBRAS tramitou lentamente no Congresso. A criação da empresa só foi possível através da lei 3890-A de 25/04/1961 com a publicação de seu estatuto em Diário Oficial apenas em 16/05/1962, no governo de Jânio Quadros. As fortes pressões de capitais estrangeiros, contra a intervenção estatal no setor elétrico, no governo de Kubistchek, podem ser a explicação para o atraso da criação da ELETROBRAS devido ao enorme peso das empresas multinacionais que foram privilegiadas pela ação reguladora do

\footnotetext{
${ }^{92}$ Segundo Francisco de Oliveira (1989), para o Plano de Metas nacional, adotado pelo Governo Kubitschek, o recurso ao capital estrangeiro, sob forma de investimento direto e sem cobertura cambial foi utilizado à exaustão: "Praticamente todo o capital destinado à indústria automobilística, à construção naval e outros contemplados no Plano de Metas, com o que e nessas condições, solucionava-se o problema do financiamento externo da acumulação de capital".
} 
Estado via $\mathrm{BNDE}^{93}$. Com a maior abertura para o capital estrangeiro há uma mudança no caráter do desenvolvimentismo, a componente nacionalista enfraqueceu diante do novo quadro da economia capitalista mundial, marcado pela recuperação econômica e forte expansão da dominação externa. ${ }^{94}$

A ELETROBRAS como empresa pública poderia tornar-se concorrente das multinacionais, como também proteger as empresas privadas nacionais.

As mudanças no cenário político a partir de 1961, com a renúncia de Jânio Quadros ${ }^{95}$ e a ascensão de João Goulart ${ }^{96}$ desencadearam uma crise marcada pela redução nas taxas de crescimento e pelo aumento da inflação. Depois da queda de João Goulart, com o golpe de 64, transformações políticas profundas ocorreram no setor elétrico.

Há uma diferença no tempo de trajetória dos projetos hidrelétricos e das fases do "ciclo" desenvolvimentista brasileiro (1961-1967, primeira fase do "ciclo", e 1968-1973, segunda fase). O desencontro entre o ciclo desenvolvimentista e as fases de elaboração de projetos e de construção de uma usina hidrelétrica pode ser explicado pelo caráter de longo prazo dos projetos hidrelétricos em contraposição ao curto prazo das políticas econômicas, que foram implementadas para tentar solucionar as diversas crises brasileiras.

A construção de usinas hidrelétricas envolve grandes grupos econômicos nacionais e estrangeiros. O processo de produção de energia tem como exigência um planejamento estadual e federal porque envolve uma grande concentração de capital e exige constantes transformações tecnológicas e administrativas. ${ }^{97}$

\footnotetext{
${ }^{93}$ BNDE foi criado pela lei 1628 de 20/06/1952, como entidade nacional de financiamento, atual BNDES.

$94 "(\ldots)$ a direção econômica sob Kubistchek privilegiou a entrada maciça de capital estrangeiro nas áreas novas, sob o envoltório ideológico do desenvolvimentismo (...)" (DRAIBE, 1985).

${ }^{95}$ Quanto à crise econômica brasileira, segundo Francisco de Oliveira (1989), "deve-se dizer que as presidências de Quadros e Goulart na verdade foram prisioneiras da crise que começou a detonar no último ano da Presidência Kubitschek".

${ }^{96}$ O período Goulart intenta uma política econômica - o Plano Trienal de Furtado, que vai levar à falência toda a política econômica, e não apenas ela, o regime democrático também. OLIVEIRA (1989, p.91).

${ }^{97}$ A criação das várias empresas de energia elétrica pelo governo brasileiro insere-se nesse
} 
A associação entre o Estado e o capital estrangeiro já seria em si uma indicação de mudança: "esperava-se para as empresas estatais performances lucrativas, sem o que o capital estrangeiro não participaria ${ }^{98}$. A transformação apenas será explicitada e aprofundada no período pós-64, exatamente pela mudança na correlação de forças políticas que fundaram o regime a partir de então.

O fracasso da política econômica dos primeiros governos militares fez surgir um novo nacionalismo apoiado numa postura tecnológica para o setor elétrico, e como premissa buscou a transferência de know-how e a abertura ao capital estrangeiro, limitando a criação de tecnologia própria. Entre 1968 e 1973, os militares passaram a controlar o setor elétrico através de uma ação conjunta do Ministério das Minas e Energia e das grandes empresas energéticas federais - PETROBRAS, ELETROBRAS e NUCLEBRAS.

Somente com a implantação de grandes projetos na década de setenta como Itaipu, Tucuruí e Sobradinho - e com uma reação cada vez mais intensa e organizada dos segmentos sociais atingidos pela construção de barragens, que a problemática sócio-ambiental alcançou alguma visibilidade e pôde pressionar as empresas do setor para adoção de medidas compensatórias de acordo com os interesses e necessidades dos atingidos, especialmente os expropriados que sofreram com o deslocamento compulsório de suas propriedades.

Em 1974, a alteração das forças políticas que participavam do poder foi marcada pela indicação de Ernesto Geisel para substituir Garrastazu Médici. Neste período o governo militar sofreu profundo desgaste no plano político principalmente pelo impacto negativo da política de segurança interna, que foi caracterizada pela manutenção de prisioneiros políticos, torturas e restrições à liberdade de pensamento e imprensa, além da promulgação dos Atos Institucionais e pacotes econômicos casuísticos. Nesse momento houve uma priorização aos grandes projetos e uma tentativa de retomada do processo de

processo e visa explorar as bacias dos rios de elevado potencial hidráulico, envolvendo grandes grupos econômicos nacionais e estrangeiros, base do tripé que sustenta 0 desenvolvimentismo hidrelétrico (FROELICH, 2001).

${ }^{98}$ Segundo Francisco de Oliveira (1989). 
industrialização do país. No plano político o modelo autoritário adotou uma política de abertura gradual. ${ }^{99}$

Em 1979, João Baptista Figueiredo foi indicado para o lugar de Ernesto Geisel na Presidência da República e seu período de governo (1980-1985) foi marcado pelo esgotamento do processo de modernização conservadora. ${ }^{100}$

Com a abertura democrática, no início dos anos 80, e a nova constituição as obras de hidrelétricas têm um novo enquadramento legal. Os órgãos financiadores de grandes projetos, como o Banco Mundial, passaram a condicionar a concessão de recursos à elaboração de um plano de remanejamento populacional, exigindo no quadro do planejamento, técnico e econômico da obra, referências ao tratamento a ser dado à população local. $O$ BIRD - Banco Internacional de Reconstrução e Desenvolvimento - em 1980, estabelece uma norma - Operational Manual Statement 2.33; Social Issues Associated with Involuntary Ressettment in Bank Financed Projects - que contém regras e procedimentos para preparação, avaliação e supervisão do remanejamento involuntário de populações em projetos financiados pelo Banco. Apesar do estímulo dos organismos internacionais para 0 fortalecimento dos mecanismos e técnicas de participação e do avanço no processo decisório publicizado, as representações dos grupos sociais correspondem apenas a alguns segmentos mais organizados e nem todos os atores conseguiram se fazer representar.

Cada concessionária, retratando as especificidades das políticas públicas regionais e estaduais, respondeu diferenciadamente às diretrizes governamentais e a um novo programa de reassentamento, que apesar de não ser exigido por lei, constituiu-se num conjunto de diretrizes que passaram a

\footnotetext{
99 "Embora sob regimes diferentes - ditadura com Ernesto Geisel, democracia com Juscelino Kubistchek - o desenvolvimentismo apresentou elevado custo para a nação: se o Plano de Metas teve como corolário a inflação, o II PND foi o responsável pelo aumento do endividamento externo do país, especialmente por causa dos mega projetos idealizados no governo Geisel, nem todos bem escolhidos nem bem sucedidos" (FROELICH, 2001).

100 "... o país começa a viver uma situação nova caracterizada pela paulatina instalação de uma grave crise econômica de natureza hiper inflacionária e pelo início de um limitado processo de democratização, baseado na consolidação da política de abertura lenta e gradual adotado por Ernesto Geisel" (FROELICH, 2001).
} 
reger a política do setor elétrico a partir de $1986^{101}$, quando a ELETROBRAS publicou o Manual de Estatutos e Efeitos Ambientais dos Sistemas Elétricos. E, no mesmo ano, foi publicado o Plano Diretor para Proteção e Melhoria do Meio Ambiente nas obras e serviços do setor elétrico, onde se fez a primeira referência ao reassentamento de populações. Os projetos de reassentamento ganharam importância e passaram a compor um capítulo no RIMA - Relatório de Impactos Ambientais -, que era o principal documento de licenciamento das usinas hidrelétricas. A Política Nacional de Meio Ambiente - PNMA - foi instaurada entre 1982/84, mas na realidade, começou a ser implementada a partir de 1988, com a Constituição, para: "preservação, melhoria e recuperação da qualidade ambiental propícia à vida visando assegurar no país, condições ao desenvolvimento sócio-econômico, aos interesses da segurança nacional e proteção da dignidade da vida humana". ${ }^{102}$ A criação da PNMA gerou um órgão com estatuto ministerial, o Ministério de Desenvolvimento Urbano e Meio Ambiente (1985), que foi extinto no governo Collor (1989-92), sendo criada a Secretaria do Meio Ambiente ligada à Presidência. Em 1993, a área volta a ganhar estatuto ministerial com o Ministério do Meio Ambiente e da Amazônia Legal. Com o PNMA e a partir da criação do Conselho Nacional do meio Ambiente $^{103}$ - CONAMA - o Estado passava a ter responsabilidade pelos danos ambientais causados por suas próprias atividades. O PNMA possibilitou a participação pública no CONAMA e no processo de licenciamento de atividades por meio de audiências públicas.

Segundo WALDMAN (p.87-88, 2002), a criação de salvaguardas "jurídico-ambientais" como o RIMA e o EIA - Estudo de Impacto Ambiental, seriam objetos de controvérsias, porque em tese possibilitariam ao poder público induzir ou mesmo rejeitar a implementação de hidrelétricas, no entanto, na prática não têm eficácia para deter tais empreendimentos e apenas cumprem uma função teatral para garantir a aprovação dos empréstimos: "Na melhor das hipóteses, os Rima se limitam a fazer uma previsão da catástrofe, um exercício precário de futurismo" (PIB/CEDI, 1991, p.80)

\footnotetext{
101 Segundo Rebouças (2000).

102 Lei 6.938, art.2‥

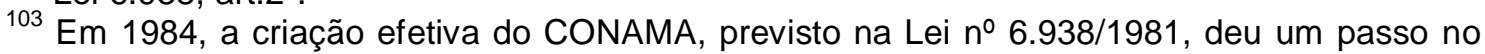
sentido de articular a política ambiental explícita com as políticas de meio ambiente, implícitas nas demais políticas de governo - de energia e outras (ACSELRAD, 2001, p.79).
} 
No âmbito dos movimentos sociais, merece destaque a organização dos segmentos sociais atingidos pela construção de usinas hidrelétricas no sul do país, que em torno da defesa de seus interesses, assumiu contornos sólidos na criação da CRAB - Comissão Regional dos Atingidos por Barragens. Em 1979, teve início o movimento dos atingidos por barragens na sub-região do Alto Uruguai - ou Movimento dos Atingidos por Barragens da bacia do rio Uruguai $^{104}$. Um dos fatores o que pode explicar a dinâmica do movimento relativo às barragens foi a atuação da Igreja Católica ${ }^{105}$, que proporcionou as ligações de comunicação intra e interinstitucional ao movimento na região e em nível nacional. As Igrejas locais, os sindicatos de trabalhadores rurais e as cooperativas constituíram "redes de interação preestabelecidas" que facilitaram o "recrutamento em bloco" de participantes do movimento. ${ }^{106} \mathrm{O}$ projeto que a Igreja pretendia implantar era a construção de uma "sociedade nova" e o desenvolvimento da "democracia de base" através da "participação". Dois temas se destacaram no ideário da Igreja progressista, a visão comunal - não societal, e a ligação entre a fé e a política:

No período 1979 - 1983, a abertura ideológica, estimulada pela abertura política e pelo crescimento da mobilização, facilitou a utilização de recursos ideológicos, constituídos pela interação de idéias internas e externas à região, nos processos de conscientização das populações atingidas pelas barragens (ROTHMAN, 1996).

A concepção dos agentes pastorais incentivaria a "política da recusa". Essa recusa se expressa no grito de guerra "Terra sim, barragem não", a marca do movimento entre 1983 e 1985 (NAVARRO, 1990).

Um marco para uma nova forma de tratamento das questões sócioambientais, foi o acordo entre a ELETROSUL e a CRAB, em 1987, que especificou os procedimentos para o pagamento de indenizações e para o remanejamento da população atingida pela construção da UHE de Itá, que resultou na construção de Nova Itá. Essas conquistas imprimiram mudanças

\footnotetext{
${ }^{104}$ MORAES (1996).

${ }^{105}$ Segundo ROTHMAN (1996).

${ }^{106}$ McADAM (1982).
} 
significativas nas relações do setor elétrico com os atingidos pelas águas de barragens e proporcionaram uma abertura de alcance nacional. Em 1991, acontece o I Congresso Nacional de Trabalhadores Atingidos por Barragens, em Brasília, quando o MAB - Movimento dos Atingidos por Barragens torna pública a "Carta de Brasília" ${ }^{107}$, demonstrando a determinação de um milhão de atingidos em manter a luta pela revisão estrutural da política energética do Estado brasileiro.

A carta questionou as políticas públicas de construção de barragens para a geração de energia elétrica ou irrigação. $O$ documento denunciou os problemas que as políticas públicas vigentes, baseadas em um modelo de desenvolvimento que concentra riquezas, serviam aos interesses do "grande capital" e geravam a exclusão dos atingidos. Denunciou que os grandes projetos de produção de barragens geravam desastrosos efeitos para a população atingida. As políticas de construção de barragens tinham significado para os trabalhadores a expulsão da terra e a conseqüente destruição de comunidades rurais. E, ainda denunciou o empobrecimento dos trabalhadores rurais e dos indígenas nas regiões onde se instalavam as barragens e a destruição do meio ambiente, especialmente a morte dos rios e dos peixes. Este quadro justificaria a criação do Movimento Nacional dos Trabalhadores Atingidos por Barragens, que articulou movimentos locais e regionais de luta pela terra e visou profundas reformas nas políticas energéticas e de implantação de projetos de irrigação vigentes até então.

\footnotetext{
${ }^{107}$ A Carta de Brasília data de 14 de março de 1991, e levou as seguintes assinaturas: ARQMO - Associação dos moradores de Jaguaribara, CABT, CAHTU, CNS, COIAB, Comissão de Defesa do Rio Uatumã, Comissão Nacional dos Atingidos pelas Barragens da Amazônia, CONTAG, CRAB, CRACOHX, CUT NACIONAL/DNTR, FETAET, FETAGIPA, FETAPE, MST, Pólo Sindical do Submédio São Francisco, Povo Indígena Arara, Povo Indígena Asuriní do Tocantins, Povo Indígena Baré,Povo Indígena Gavião, povo Indígena Gavião da Montanha, Povo Indígena Kaingang, Povo Indígena Krikati, Povo Indígena Macuxi, Povo Indígena Munduruku, Povo Indígena Mura, Povo Indígena Tuxá, Povo Indígena Tucano, Povo Indígena Xokleng, Sindicato dos Eletricitários da Bahia. CAMPO, CEDI, CEPAMI, CESE, CETAP, CIMI, CIR, CNRA, Comissão Pastoral Urbana de Barragens/RJ, Comissão Pró-Indio de São Paulo, CPT, FASE, IBASE,IECLB, INESC, IPPUR/UFRJ, MNDDII, OXFAN, Secretaria Agrária Nacional do Partido dos Trabalhadores, Vianei.
} 
A Carta trouxe as seguintes exigências: o cumprimento imediato dos acordos celebrados entre o movimento e o setor elétrico, visando solucionar a situação dos atingidos; a priorização dos recursos do setor elétrico para a solução dos graves problemas sociais e ambientais decorrentes da implantação e funcionamento das barragens apontava que; que a definitiva solução dos problemas sociais e ambientais gerados pelas barragens seria a condição à implantação de novos projetos; reivindicava ainda: o fim do processo de venda das empresas estatais do setor elétrico, que são patrimônio do povo brasileiro; a reforma da atual política energética com a participação dos atingidos e do conjunto da sociedade; a reforma da atual política de projetos de irrigação, visando o real benefício dos trabalhadores rurais; pleno respeito aos direitos dos povos indígenas, ao seu território, e demarcação imediata das terras indígenas, demarcação das terras de remanescentes de quilombos e reforma agrária.

Os atingidos, enquanto movimento social, é distinto e diferenciado dos movimentos sociais 'clássicos' (como o operário), ainda que em diversos momentos o sindicato tenha sido palco da primeira reunião, da primeira reivindicação, da primeira manifestação. Agrupando enorme diversidade de populações tradicionais, os atingidos desenvolvem lutas que conjugam defesa do meio ambiente com valores culturais tidos como 'do passado', mas que ao pretenderem um desenvolvimento econômico não consumista e não devorador de recursos energéticos, estão apontando para o futuro. (...) os atingidos estão pondo em xeque uma organização do espaço (WALDMAN, 2002, p.87).

Apesar da promulgação da nova constituição em 1988, as mudanças imediatas no governo tiveram caráter conservador, principalmente no que se referia ao tratamento dado aos atingidos pelas obras do setor elétrico. $O$ desafio que se impunha ao setor elétrico era a falta de prática e a dificuldade de se trabalhar em um novo ambiente institucional, quando emergia um novo conjunto de normas e regulamentos ambientais e de participação social. Para a implementação de seus projetos, o setor elétrico adotava a prática da persuasão com publicidade, propaganda e relações públicas. O desafio seria 
passar de um modelo de participação social de caráter deliberativo para o de co-responsabilidade:

Cinco pontos foram levantados naquele momento: a questão da credibilidade e da estabilidade de conduta do empreendedor; os custos e a duração do processo participativo; a representatividade das lideranças da população; a natureza das questões abrangidas como requisito de participação; a participação e a existência de uma zona de contato (FROTA, 2001, p.155).

O contato entre os agentes do setor elétrico pressupõe a criação de canais de comunicação com a sociedade, a aceitação das formas de representação popular, estratégias de inserção regional, a articulação institucional das políticas públicas, a readequação do modelo de gestão dos empreendimentos e o reconhecimento da assimetria de informação e do poder entre os agentes.

A criação de instâncias de arbitragem e resolução de conflitos, de forma descentralizada, depende de marco legal prévio e grande parte dos estados brasileiros não avançou na criação dos comitês de bacia hidrográfica. Os comitês são instâncias de arbitragem de conflitos e formulação de critérios alocadores de recursos hídricos, com marco legal, na formação de comitês regionais com poder decisório e de uma busca da produção de consenso entre os diversos atores envolvidos, de base regionalista e descentralizadora, além de operar com os planos das bacias hidrográficas. Em face da trajetória para um modelo descentralizado dos estados brasileiros, ao longo dos anos 90, a União foi pressionada a adotar um sistema nacional de gerenciamento dos recursos hídricos ${ }^{108}$. No final dos anos 90, foi criada a ANA - Agência Nacional de Águas ${ }^{109}$-, subordinada ao Ministério do Meio Ambiente, com a missão de implementar no conjunto do país a política nacional de recursos hídricos. ${ }^{110}$

\footnotetext{
${ }^{108}$ Lei $9.433 / 1997$.

109 Projeto de Lei $1617 / 99$.

110 Segundo NEDER (2002), nada assegura que seu papel será como reza o texto legal, "de coordenação do sistema de gerenciamento descentralizado, com a participação de entidades da sociedade civil, prefeituras e agências estaduais/federais em torno dos comitês de bacias".
} 
Em Minas Gerais, constatou-se a criação de organismos gestores por bacia sob o formato de comitês tripartites - com representação social de usuários e entidades técnicas, sindicais, ONGs, usuários domésticos e econômicos e representantes das prefeituras e do Estado- ${ }^{111}$. No estudo de caso da construção da barragem da usina hidrelétrica de Nova Ponte, não há registro da participação ou da formação de comitê de bacia hidrográfica.

A eclosão dos movimentos sociais desencadeados a partir de empreendimentos hidrelétricos tornou público o leque de problemas que permeiam a elaboração da política energética brasileira. Esses conflitos políticos foram acompanhados, por sua vez, pela emergência de questões ambientais que entraram em cena desde o final da década de 60, com maior destaque em meados dos anos 80 . Em relação ao meio ambiente, o principal fórum para essa discussão se constituiu durante a ECO - 92 $2^{112}$, - a CNUMAD Conferência das Nações Unidas para o Meio Ambiente e Desenvolvimento - e o encontro paralelo, a Conferência da Sociedade Civil sobre Meio Ambiente e Desenvolvimento ou Fórum Geral, realizados no Rio de Janeiro, que tiveram como tema central o desenvolvimento sustentável, com origem há dez anos atrás, a partir da teoria do ecodesenvolvimento (Ignacy Sachs) aplicável em países do Hemisfério Sul e com base em quatro princípios:

As propriedades do desenvolvimento deverão estar ao alcance de finalidades sociais; o princípio básico de ação é valorizar a autonomia (self-relience); os sistemas socioeconômicos devem ser orientados para a busca de uma relação de simbiose com a natureza e a eficiência econômica deve superar desperdícios e padrões de consumo opulento (SACHS, 1986).

Documentos importantes foram assinados durante a CNUMAD, como: a

\footnotetext{
111 São Paulo e Ceará levaram mais longe a construção dessa esfera pública de arbitragem de caráter regional com a criação de uma rede de comitês (NEDER, 2002). Em São Paulo essa rede foi aprofundada, sobretudo a partir de 1998 em regiões onde a industrialização acarreta maiores riscos de qualidade e quantidade de água, ou bacias agro-industriais sensíveis como Alto Tietê, Piracicaba e Campinas e Alto Paraíba (BARTH, 1993).

${ }^{112} \mathrm{O}$ evento foi organizado pelas Nações Unidas - ONU - e aconteceu no Rio de Janeiro, oficialmente envolvendo diversas organizações sociais brasileiras e internacionais e seus representantes governamentais.
} 
"Agenda 21" 113, a "Convenção sobre Biodiversidade" 114, "Convenções sobre Alterações Climáticas" 115, "Declaração sobre as florestas" ${ }^{116}$ e a "Declaração do Rio" ${ }^{117}$. No Fórum Global, foi elaborada a "Carta da Terra", nela se reconhece que "nós somos a Terra, os povos, as plantas e animais, gotas e oceanos, a respiração da floresta e o fluxo do mar. Nós honramos a Terra, como lar de todos os seres viventes. Nós estimamos a Terra, pela sua beleza e diversidade de vida. Nós reconhecemos a especial posição dos povos indígenas da Terra, seus territórios e costumes, e sua singular afinidade com a Terra. Nós reconhecemos que o sofrimento humano, pobreza e degradação da Terra são causados pela desigualdade do poder. Nós aderimos a uma responsabilidade compartilhada de proteger e restaurar a Terra, para permitir o uso sábio e eqüitativo dos recursos naturais, assim como realizar o equilíbrio ecológico e os novos valores sociais, econômicos e espirituais. Em nossa inteira diversidade somos unidade. Nosso lar comum está crescentemente ameaçado".

No entanto, ao longo do processo preparatório da conferência no Rio de Janeiro, o governo Collor abriu apenas um espaço formal para a participação, que contou com um representante para definir a posição brasileira nas negociações e houve pouquíssima articulação entre a delegação do governo brasileiro e a representação de ONGs, diferentemente do ocorrido com inúmeros países participantes. ${ }^{118}$

A Conferência do Rio, segundo SILVA (1996), possibilitou a emergência de um espaço público de dimensão mundial, e o principal, a "sociedade civil global" começa a se mobilizar no sentido de buscar uma participação ativa nas decisões que interfiram na vida do planeta. Juntos, a Conferência do Rio e o

\footnotetext{
${ }^{113}$ Programa de ação para o desenvolvimento sustentável, que inclui temas como a pobreza, habitação, saúde, transferência de tecnologia, desmatamento, desertificação, mudanças climáticas, modelos de consumo (SANTOS e CÂMARA, 2002).

114 Documento que objetiva promover a preservação e conservação da biodiversidade do planeta.

${ }_{116}$ Objetiva proteger a atmosfera.

116 Documento visa contribuir para a preservação e o desenvolvimento sustentável das florestas.

${ }_{117} \mathrm{O}$ documento tem o objetivo de estabelecer uma nova e eqüitativa parceria global, mediante a criação de novos níveis de cooperação entre Estados, setores sociais estratégicos e populações, visando acordos internacionais que respeitem os interesses de todos e protejam a integridade do sistema ambiental e do desenvolvimento global.

${ }^{118}$ ACSELRAD (2001).
} 
Fórum Global, reuniram representantes de 180 países, estiveram presentes cerca de 185 chefes de Estado, além de cerca de sete mil organizações não governamentais - ONGs de todo o mundo, com cerca de 20 mil participantes.

A importância de se produzir conhecimentos sobre os fenômenos naturais e sociais associados à geração de energia no Brasil é um fato inquestionável. Considerando que apenas nos oito maiores reservatórios brasileiros construídos, foi estimada uma população superior a 300 mil pessoas já remanejadas, e o programa de expansão da ELETROBRAS prevê a realização de estudos para avaliar a implantação de mais de 494 usinas hidrelétricas no Brasil até 2015 - estima-se que mais de 850 mil pessoas serão expulsas de suas terras ${ }^{119}$.

Somente a CEMIG, nos últimos dois anos, concluiu as hidrelétricas de Funil no rio Grande, Queimado no rio Preto à noroeste de Minas, e está construindo o complexo Capim Branco no rio Araguari, a hidrelétrica de Aimorés no rio Doce à leste de Minas, e implantando a hidrelétrica de Irapé no rio Jequitinhonha. No caso de Aimorés, a cidade de Itueta em Minas, será inundada pelo lago da usina, quando serão remanejados 1.200 moradores para a cidade planejada de Nova Itueta, a partir de 2005.

Com a construção da hidrelétrica de Irapé - Usina Presidente Juscelino Kubitschek $^{120}$ - dois povoados serão inundados: o Peixe Cru e Porto Coris. Em fevereiro de 2005, 600 famílias aguardavam o reassentamento para o novo Peixe Cru. O povoado de Porto Coris abrigava 19 famílias remanescentes de quilombos que foram reassentadas na agrovila de Porto Coris em dezembro de 2004. A CEMIG prometeu a construção de um Centro de Referência e Memória para a agrovila e o projeto foi definido pela comunidade. A exemplo de Nova Ponte, foram criadas 28 associações comunitárias nestes dois povoados para negociar com a CEMIG. Em artigo recente de jornal, a CEMIG se vangloria de sua postura frente aos atingidos:

Somente com a relocação das famílias (dos povoados de Peixe Cru e Porto Coris) e outras ações ambientais, a CEMIG está

\footnotetext{
${ }^{119}$ Dados do MAB - Movimento dos Atingidos por Barragens.

${ }^{120}$ UHE JK foi iniciada em 2002.
} 
investindo cerca de $R \$ 200$ milhões, usando toda a sua experiência adquirida em mais de 50 anos na construção de hidrelétricas e relocação de famílias, ações que fizeram da empresa padrão no setor elétrico brasileiro e referência em ações ambientais (Jornal da Manhã, 04/05/2005).

O marco no tratamento da concessionária com os atingidos pela construção de barragens no Estado e no país, é a cidade de Nova Ponte. Foi somente a partir da luta pela cidade de Nova Ponte, com a organização de sua população que foi possível a criação de novos canais de negociação com a CEMIG, o que resultou na construção de uma nova cidade.

No que se refere à construção de cidades novas no Brasil, a historiografia produzida nos últimos quinze anos, apesar de impulsionada pelas pesquisas de pós-graduação e por encontros nacionais de pesquisadores vinculados à história urbana, do urbanismo e do planejamento urbano ${ }^{121}$, expõe lacunas que demonstram o quanto ainda se tem a estudar sobre a rica experiência urbanística de construção de cidades novas no país. Em particular, assume importância o estudo sobre as cidades planejadas para abrigar as populações atingidas pela construção de hidrelétricas, quando velhas práticas adotadas para a cidade de Nova Ponte se constituíram em um "modelo" que continua sendo aplicado no país, com algumas variações de natureza regional. Além dos exemplos descritos no texto, que foram implementados pela CEMIG em Minas, se destaca o exemplo da construção de Nova Jaguaribara no Ceará, inaugurada em 25 de setembro de $2001^{122}$, que teve a velha sede inundada para a construção da barragem do Açude do Castanhão. Aqui, mesmo depois de passadas mais de três décadas do início da construção de Nova Ponte e de instalada a democracia no país, o processo do reassentamento involuntário continuou o mesmo, salvo uma maior organização das entidades envolvidas o que resultou em uma maior visibilidade do processo. Além da Associação dos Moradores de Jaguaribara, mereceram destaque a Igreja Católica, ONGs e o MAB.

\footnotetext{
121 ANDRADE (2005).

122 PEROTE, "O urbanismo de Nova Jaguaribara" In Caderno de Resumos do X Encontro Nacional da ANPUR, Belo Horizonte, 2003.
} 
(...) 50 grandes barragens se encontram em construção e nos próximos três anos do governo Lula estão projetados a construção de mais 70 grandes barragens. Porém, os mesmos planos do governo em nenhum momento apontam o número de famílias atingidas, não existe nenhum estudo real por parte do governo quanto ao número de famílias a serem expulsas, mas o MAB possui estimativa de que este número chegue a 100 mil famílias expulsas pelo atual governo. (...) Dados do MAB apontam que a cada 100 famílias deslocadas, 70 não receberam nenhum tipo de indenização (MAB - Dossiê: "Ditadura contra as populações atingidas por barragens aumenta a pobreza do povo brasileiro", 2004).

O MAB reafirma sua posição e exige do governo brasileiro a formulação de uma política energética ${ }^{123}$ que: suspenda os subsídios aos grandes consumidores e não renove seus contratos, em particular as indústrias eletrointensivas; garanta o controle do povo brasileiro sob a água e energia, por serem bens estratégicos para a soberania nacional; pare com a privatização e a mercantilização do setor energético, principalmente no que diz respeito à água, energia e a biodiversidade; garanta energia elétrica e água para todas as famílias do país; contemple a participação da população previamente informada em seu planejamento, decisão e execução; que nenhuma barragem seja construída sem o consentimento prévio e informado das populações atingidas; execute as dívidas das empresas elétricas privatizadas e retome 0 controle público estatal sobre o setor; priorize as questões sociais e ambientais; resgate a dívida social e ambiental do setor nas barragens construídas e em construção; acabe com o desperdício na transmissão, distribuição e consumo de energia; priorize investimentos em pesquisa, no desenvolvimento e na implementação de fontes energéticas alternativas; tenha uma política de preços, com baixo custo ao povo brasileiro, em especial os trabalhadores de baixa renda.

Os impactos sócio-ambientais ${ }^{124}$ da implantação de projetos são objeto

\footnotetext{
${ }^{123}$ Documento veiculado pelo MAB e intitulado "Plataforma do Movimento de Atingidos por Barragens - Ações Prioritárias", de 16 de fevereiro de 2003.

${ }^{124} \mathrm{O}$ impacto ambiental é definido pelo CONAMA, como "qualquer alteração
} 
de debate, estudos e propostas de especialistas e mesmo de órgãos públicos, especialmente na esfera do MME - Ministério das Minas e Energia -, e um novo modelo do setor elétrico foi recentemente aprovado e está em fase de regulamentação ${ }^{125}$. O assunto, pela primeira vez na história do setor elétrico, foi tema incluído na agenda oficial do Governo Federal, por meio de decreto presidencial. Em 2003, foi formado o GTI - Grupo de Trabalho Interministerial com a finalidade de analisar as demandas apresentadas pela sociedade civil organizada, representativa dos atingidos por barragens, formular diagnóstico e elaborar propostas para o equacionamento dos problemas identificados ${ }^{126}$. No relatório final, o GTI, tomando por base as reivindicações do MAB e diversos pontos discutidos no ciclo de audiências, que contou com a presença de representantes do movimento, e em reuniões internas do Grupo, reconheceu como os problemas centrais: a inexistência de critério para identificação de atingidos por barragens; a insuficiência do conteúdo social na elaboração do EIA/RIMA; a precariedade do processo de cadastramento socioeconômico; a falta de informação e esclarecimento à população afetada sobre construção de barragens; a precariedade do processo de negociação entre atingidos e concessionárias; a ausência da fiscalização, pelo órgão regulador competente, de ações sociais de responsabilidade das concessionárias; a incompatibilidade entre cronogramas de construção de usinas e barragens e programas sociais voltados à população afetada; um processo de licitação distorcido por desconsiderar os efetivos custos sociais do empreendimento; o tratamento diferenciado das questões sociais no licenciamento ambiental; as deficiências nos processos de reassentamento e indenização; a participação insuficiente de Estados e Municípios no apoio aos atingidos; a falta de condicionantes sociais em financiamentos a hidrelétricas; a privatização das águas dos reservatórios por concessionárias; e a dívida social e questões emergenciais.

das propriedades físicas, químicas e biológicas, causada por qualquer forma de matéria ou energia resultante de atividades humanas, que direta ou indiretamente, afetam a saúde, a segurança e o bem estar da população; as atividades sociais e econômicas; a biota; as condições estéticas e sanitárias do meio ambiente; e a qualidade dos recursos ambientais".

${ }_{125}^{125}$ Leis no 10.847 e ํㅜ 10.848 , de 15 de março de 2004.

${ }^{126} \mathrm{O}$ GTI encerrou seus trabalhos com a elaboração de um relatório final entregue em Brasília em maio de 2004. 
A criação do GTI foi o primeiro espaço que o Governo Federal abriu oficialmente para discutir os problemas que afligem os atingidos por barragens. Os problemas são de grande envergadura e foram divididos em três grupos básicos: "Como os atingidos vêem o problema e qual o papel que esperam do governo; discussão da pauta de reivindicação dos atingidos; exposição da questão do cadastro dos atingidos".

De forma geral não há reconhecimento dos problemas da população atingida, sobretudo aquela que não detêm a propriedade das terras inundadas pela lâmina d'água e seu entorno. O relatório final do GTI reconheceu que "essa população é vista como um incômodo, e precisa ser removida de seus locais para permitir a geração de energia elétrica". Ressaltou também, que cerca de 1,5 milhão de agricultores familiares é constituída de posseiros, aproximadamente $36 \%$ do total, o que é um indicador da estrutura da posse de terra no Brasil. O documento reconhece que $70 \%$ dos atingidos sequer aparecem nos cadastros, como os meeiros e os arrendatários, não fazendo parte da lista de beneficiados e levando-os a fazer mobilizações para que seus direitos sejam reconhecidos. As propostas apresentadas durante as reuniões do GTI, que foram apresentadas em um relatório final (Tabela 01). 
Tabela 09. Relatório final do Grupo de Trabalho Interministerial - GTI (2004).

\begin{tabular}{|c|c|c|}
\hline $\begin{array}{l}\text { Problemas } \\
\text { Identificados }\end{array}$ & Propostas & $\begin{array}{l}\text { Órgãos } \\
\text { Responsáveis }\end{array}$ \\
\hline $\begin{array}{l}\text { Necessidade de ações } \\
\text { emergenciais: cestas básicas } \\
\text { e crédito agrícola }\end{array}$ & \multirow[t]{2}{*}{$\begin{array}{l}\text { Continuidade das ações desenvolvidas pela Mesa } \\
\text { de Negociações Governo/Atingidos }\end{array}$} & $\begin{array}{l}\text { Mesa de } \\
\text { Negociações da SG/ } \\
\text { MDA e MDS }\end{array}$ \\
\hline $\begin{array}{l}\text { Dívida social do setor } \\
\text { hidrelétrico com os atingidos }\end{array}$ & & $\begin{array}{l}\text { Mesa de } \\
\text { Negociações } \\
\text { SG/PR, MDS, MDA, } \\
\text { MME (articulação com } \\
\text { ANEEL, ELETROBRAS, } \\
\text { BNDES, Prefeituras, Secs., } \\
\text { Ests. e entidades do Terceiro } \\
\text { setor) }\end{array}$ \\
\hline $\begin{array}{l}\text { Falta de crédito para a } \\
\text { identificação dos atingidos por } \\
\text { barragens }\end{array}$ & $\begin{array}{l}\text { Inclusão obrigatória no conceito dos atingidos, de } \\
\text { grupos especiais e de pessoas que vivem de } \\
\text { atividades pesqueiras ou agropecuárias nas áreas } \\
\text { inundadas pelos reservatórios; Criação de } \\
\text { condições para a inclusão dos demais grupos que } \\
\text { se julguem atingidos }\end{array}$ & $\begin{array}{l}\text { MME, MI, MDA, } \\
\text { MMA, MDS }\end{array}$ \\
\hline $\begin{array}{l}\text { Insuficiência do conteúdo } \\
\text { social no EIA/RIMA }\end{array}$ & Fortalecimento dos estudos sociais no EIA/RIMA & $\begin{array}{l}\text { MME/EPE, Ibama, } \\
\text { CMSE, MI e OEMA }\end{array}$ \\
\hline $\begin{array}{l}\text { Precariedade do cadastro } \\
\text { sócio-econômico }\end{array}$ & $\begin{array}{l}\text { Aperfeiçoamento de critérios e procedimentos } \\
\text { para a elaboração do cadastro socioeconômico na } \\
\text { fase de Estudos de Inventário }\end{array}$ & $\begin{array}{l}\text { MME/EPE, Ibama, } \\
\text { CMSE, ANEEL e MI }\end{array}$ \\
\hline $\begin{array}{l}\text { Falta de informações à } \\
\text { população afetada }\end{array}$ & $\begin{array}{l}\text { Implementação de programas informativos e de } \\
\text { relacionamento com a população atingida }\end{array}$ & $\begin{array}{l}\text { MME/EPE, CMSE e } \\
\text { ANEEL. }\end{array}$ \\
\hline $\begin{array}{l}\text { Fragilidade do processo de } \\
\text { negociação entre } \\
\text { concessionárias e atingidos }\end{array}$ & $\begin{array}{l}\text { Estímulo e criação de condições de condições } \\
\text { para organização social e sua representação } \\
\text { perante as concessionárias }\end{array}$ & $\begin{array}{l}\text { MME/EPE, MI e } \\
\text { OEMA }\end{array}$ \\
\hline $\begin{array}{l}\text { Precariedade dos acordos } \\
\text { concessionárias/atingidos }\end{array}$ & $\begin{array}{l}\text { Facilitação do acordo entre as partes envolvidas e } \\
\text { sua posterior fiscalização }\end{array}$ & $\begin{array}{l}\text { CMSE, Ibama e } \\
\text { ANEEL. }\end{array}$ \\
\hline $\begin{array}{l}\text { Incompatibilidade entre } \\
\text { cronogramas técnicos, físicos } \\
\text { - financeiros e programas } \\
\text { sociais. }\end{array}$ & $\begin{array}{l}\text { Compatibilização dos cronogramas visando a } \\
\text { harmonização das etapas e a execução das } \\
\text { medidas sociais previstas }\end{array}$ & $\begin{array}{l}\text { MME/EPE e Órgão } \\
\text { de Licenciamento } \\
\text { Ambiental até a } \\
\text { obtenção da LP. }\end{array}$ \\
\hline $\begin{array}{l}\text { Falta de critérios para } \\
\text { reassentamento/indenização }\end{array}$ & $\begin{array}{l}\text { Estabelecimento de critérios com base no } \\
\text { conceito de atingidos }\end{array}$ & $\begin{array}{l}\text { MME, MI, MDA e } \\
\text { MMA }\end{array}$ \\
\hline $\begin{array}{l}\text { Tratamento diferenciado das } \\
\text { questões sociais no } \\
\text { licenciamento ambiental }\end{array}$ & $\begin{array}{l}\text { Criação do GT propondo, ao CONAMA, a } \\
\text { uniformização de critérios nas esferas Federal e } \\
\text { estaduais. }\end{array}$ & $\begin{array}{l}\text { Ministérios } \\
\text { componentes do } \\
\text { GTI com assento no } \\
\text { CONAMA }\end{array}$ \\
\hline $\begin{array}{l}\text { Participação insuficiente de } \\
\text { Estados e Municípios em } \\
\text { ações voltadas aos atingidos }\end{array}$ & $\begin{array}{l}\text { Direcionamento de parte das compensações } \\
\text { financeiras e royalties aos atingidos }\end{array}$ & MME/ANEEL \\
\hline $\begin{array}{l}\text { Ausência de condicionantes } \\
\text { sociais em financiamentos a } \\
\text { hidrelétricas }\end{array}$ & $\begin{array}{l}\text { Inclusão de condicionantes sociais em } \\
\text { financiamentos do BNDES, BIRD e BID. }\end{array}$ & $\begin{array}{l}\text { MME/EPE, } \\
\text { MP/COFIEX e MI. }\end{array}$ \\
\hline \multirow{2}{*}{$\begin{array}{l}\text { Proibição ou cobrança de } \\
\text { taxas, por concessionárias, } \\
\text { por atividades pesqueiras. }\end{array}$} & Coibição da prática de cobrança de taxas & ANA e SEAP/PR \\
\hline & $\begin{array}{l}\text { Ordenamento e estímulo às atividades pesqueiras } \\
\text { nos reservatórios }\end{array}$ & SEAP/PR \\
\hline \multirow[t]{2}{*}{$\begin{array}{l}\text { Direcionamento de ações } \\
\text { setoriais }\end{array}$} & $\begin{array}{l}\text { Programas de geração de emprego e renda, } \\
\text { qualificação e requalificação profissional e } \\
\text { Programa de Economia Solidária em } \\
\text { Desenvolvimento. }\end{array}$ & Tem \\
\hline & $\begin{array}{l}\text { Ações voltadas ao restabelecimento de laços } \\
\text { sociais e readaptação das comunidades } \\
\text { remanejadas; ações educativas específicas; } \\
\text { educação energética e sanitária; repasses do } \\
\text { FUNDEF e do salário educação. }\end{array}$ & MEC \\
\hline
\end{tabular}




\section{2. Cronologia: as etapas de planejamento, aprovação e} construção da usina e da cidade de Nova Ponte ${ }^{127}$

1965 - janeiro

Publicação do relatório "Hydro Resources of the Paranaíba Basin", elaborado pela CEMIG e pela Conanbra Engineering Consultans contendo, dentre outros, estudos sobre os aproveitamentos previstos para o rio Araguari, inclusive o de Nova Ponte.

1970 - setembro

Conclusão do "Estudo de Viabilidade Técnica e Econômica do Aproveitamento Hidrelétrico de Nova Ponte", de responsabilidade da empresa Hidro Service.

1975 - julho

Liberação da concessão através de outorga do Governo Federal a CEMIG para o aproveitamento da energia hidrelétrica da região de Nova Ponte.

1983 - março

Início do período de negociação entre a CEMIG e os órgãos ambientais responsáveis pelos setores elétricos para o licenciamento da UHE Nova Ponte.

1986 - janeiro

Apresentação do Plano Diretor de UHE Nova Ponte a lideranças de Nova Ponte. - outubro

Início da elaboração do Projeto Executivo da Usina.

1987 - fevereiro

Aprovação do Projeto Básico da UHE Nova Ponte. - março

Início do Projeto Memória Histórica de Nova Ponte. - abril

Início da Construção da usina hidrelétrica.

${ }^{127}$ Cronologia extraída do livro Memória Histórica de Nova Ponte, segundo Brandão (1997 p. 910). 
- julho

Aprovação do projeto da nova cidade (Lei Municipal no 861).

Lançamento da pedra fundamental da nova sede municipal.

1988 - março

Liberação pelo Conselho Estadual de Política Ambiental - Copam -, da licença de instalação para a UHE Nova Ponte.

- dezembro

Conclusão do Projeto Memória Histórica de Nova Ponte.

1990 - fevereiro

Assinatura do Termo de Acordo com os critérios de relocação da cidade de Nova Ponte entre a CEMIG, a Prefeitura, a Câmara de Vereadores e a Associação de Moradores.

1993 - Conclusão da mudança da população para a nova cidade.

- setembro

Concessão, pela Câmara de Defesa de Ecossistemas do Copam, da Licença de Operação para a UHE Nova Ponte.

- outubro

Início do enchimento do reservatório da usina.

1994 - março

Inauguração da nova sede municipal.

- agosto

Entrada em operação comercial da primeira unidade da UHE Nova Ponte

(Figuras. 35 e 36). 


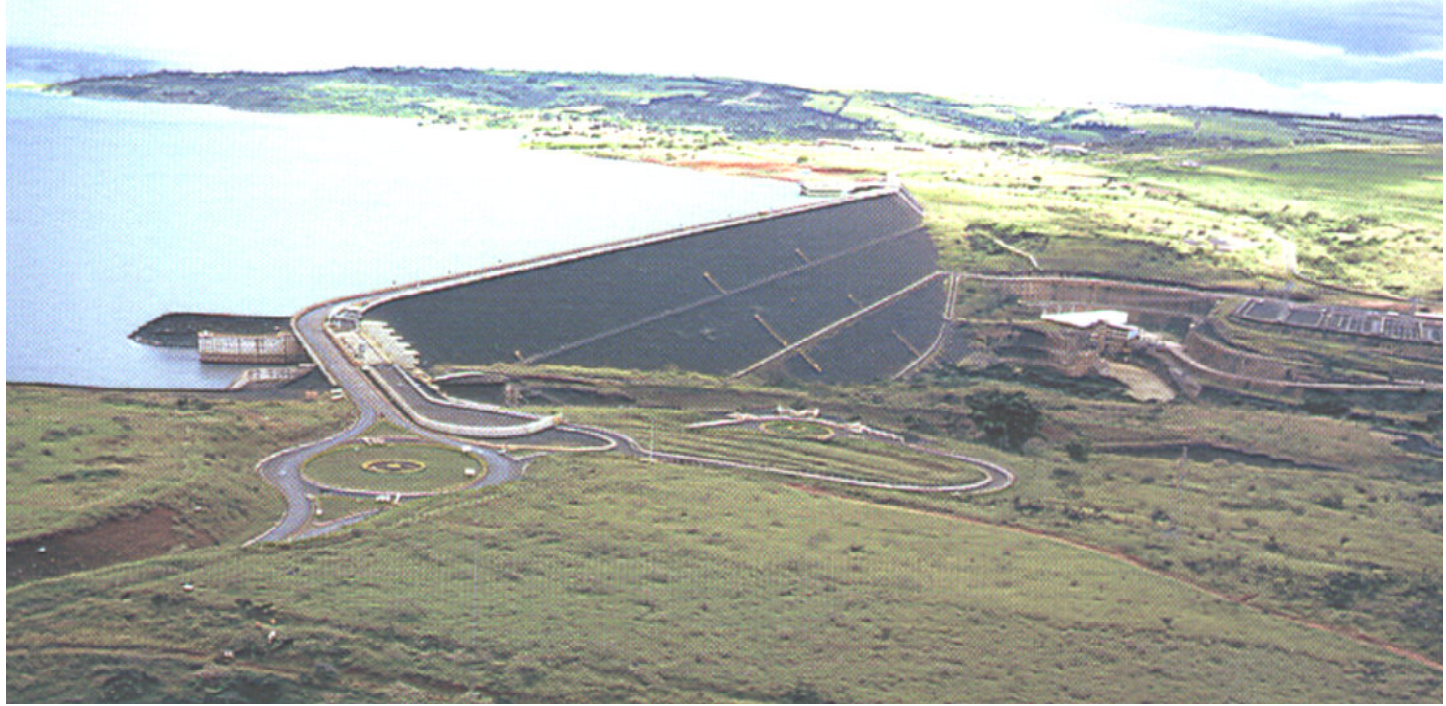

Figura. 35 - Barragem da UHE Nova Ponte. Fonte: Prefeitura Municipal de Nova Ponte.

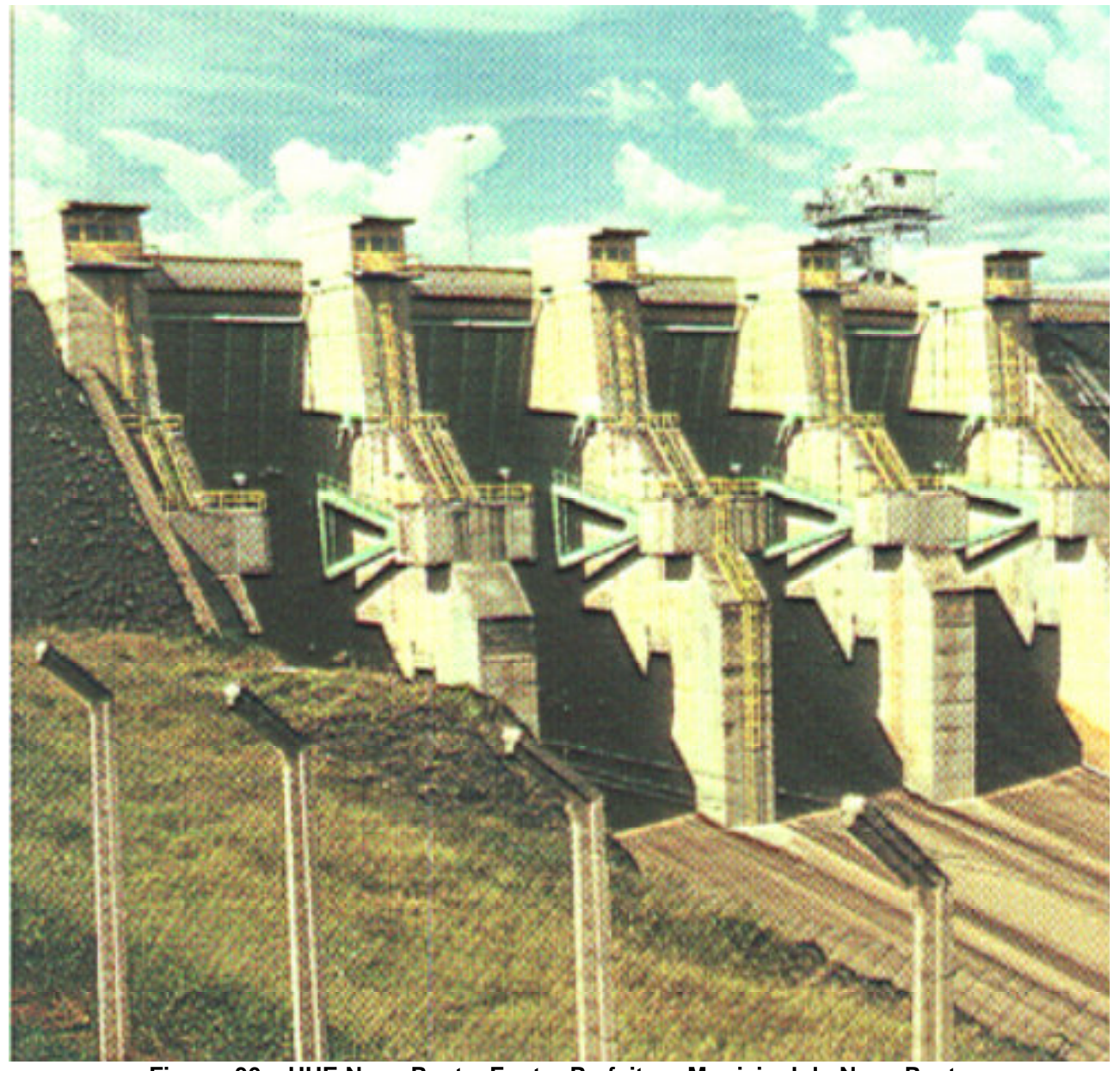

Figura. 36 - UHE Nova Ponte. Fonte: Prefeitura Municipal de Nova Ponte 


\section{Capítulo 4}

\section{A conquista do novo lugar: da euforia à saudade}

Na categoria dos grandes projetos, a construção da UHE Nova Ponte e a relocação da cidade de Nova Ponte estão inseridos em um formato particular do processo de mudança social e de reconfiguração sócio-territorial, característicos do capitalismo contemporâneo. O estudo desse caso particular, parte da temática do deslocamento e procura problematizar a questão do espaço, sua apropriação, uso e representação, passando pela necessária investigação e o registro da cultura do "lugar", analisada como um conjunto de símbolos e imagens que contém os valores que enfatizam a idéia de pertencer a instâncias coletivas de legitimação e aos códigos de distinção. Essa análise permitiria a percepção da temática e a dinâmica do processo social e histórico. Segundo Rebouças (2000), é necessário eleger a categoria do espaço como norteadora do convívio de diferentes ordens culturais, e perceber como cada agente social envolvido atua dentro de uma rede de significados.

A cidade de Nova ponte que foi planejada para abrigar 9 mil habitantes, conta atualmente com aproximadamente 14 mil habitantes. Uma nova ordem foi estabelecida pela largura de suas ruas e seu traçado, e as mudanças colocaram em questão a identidade cultural e as formas de sociabilidade de sua população. (Figura. 37 e 38).

Passados 13 anos do reassentamento, a cidade ainda é a "nova cidade" para seus moradores: "Lá a gente era dono. Aqui parece que a gente não é mais" Relata Maria Aparecida Palmieri Torres. ${ }^{128}$

Segundo Pe. Júnior: "Hoje eles estão num local chamado de Nova Ponte, mas não se sentem em Nova Ponte. A vida deles mudou, até mesmo os que continuaram sendo vizinhos - muitos deles continuaram sendo vizinhos se sentem deslocados, se sentem estrangeiros dentro de sua própria casa, na

\footnotetext{
${ }^{128}$ Moradora da cidade de Nova Ponte entrevistada em novembro de 2004.
} 
sua própria cidade. Há uma tristeza aparente muito grande. Mesmo depois de 12 anos $^{129}$, a gente não vê na nova cidade a felicidade como se via na velha, mesmo com as suas ruas esburacadas e sem infra-estrutura. $A$ vida deles era aquilo!".

Os lugares não são mais familiares aos moradores e os encontros tornaram-se raros: "O povo pergunta assim: 'Sabe onde mora fulano? - Não sei, não! A Nova Ponte era pequena, agora... não dá mais para saber onde fica tudo", conta Sebastião Fagundes, e D. Adelina Fagundes da Silva ${ }^{130}$ completa: "Aqui é difícil encontrar quem a gente via todos os dias. A gente já passou a comprar num armazém diferente. O Preto vendeu o dele. Está fazendo falta. $O$ convívio hoje é diferente. O movimento caiu. A gente sai na rua, está assim... A cidade está que nem o lago, antes era como o rio. O povo parece que está estranhando".

Na cidade nova diferentemente da velha Nova Ponte, nem todos os seus moradores são conhecidos ou parentes: "A gente vai num baile... Deus me livre! É muita gente estranha. A vida está mais corrida. Nós estamos vivendo uma época difícil. O cafezinho na vizinha, isso acabou. Até hoje só entrei no bar do Roxinha duas vezes. Eu que ia lá todo Domingo de manhã. E mesmo as praças... tem tantas agora e hoje nem se fala em praça. Os meninos iam tanto na outra praça". Declara Rosemir Carlos de Medeiros Ramos. ${ }^{131}$

A metáfora do lago e do rio retoma a questão da morte da cidade antiga. A imagem da velha cidade e do movimento das águas do rio que a atravessava, permanece viva na memória de seus moradores. Entretanto, a imagem do lago e suas águas paradas simbolizam a artificialidade e a falta de enraizamento dos moradores na nova cidade.

Os moradores da velha cidade de Nova Ponte atribuíam significação para os bares, para as esquinas onde se encontravam, para os armazéns onde

\footnotetext{
${ }^{129}$ Entrevistado em 2004.

130 Entrevistas colhidas oito anos após o reassentamento, para edição do texto de Brandão (1997).

${ }^{31}$ BRANDÃO (1997).
} 
compravam, as praças e ruas, criando territórios peculiares e específicos dentro dos espaços públicos da cidade.

Nos bairros da cidade antiga, poucas casas eram muradas, dos quintais os seus moradores avistavam a rua e vice-versa. As "salas de estar" ultrapassavam as calçadas, os estabelecimentos comerciais e as praças. $O$ índice mais marcante dessa relação era o banquinho, utilizado para as "palestras" no fim de tarde, que podia ser encontrado facilmente nas calçadas, nas soleiras das residências e nas "salas de estar" dos estabelecimentos comerciais.

A disposição das casas no interior dos bairros da velha cidade seguia a lógica da solidariedade social e do compadrio $^{132}$, sendo reproduzido em seu traçado urbano; estar perto ou longe dependia muitas vezes do grau de relação social estabelecido. No novo lugar, o traçado das ruas de acesso, verticais e horizontais, traduz uma lógica oriunda de um planejamento e estabelece uma nova ordem expressa não só na largura das ruas, mas ao convívio das pessoas. (Figura. 39).

$\mathrm{Na}$ nova cidade de Nova Ponte, seus moradores atribuem aos novos espaços uma significação bastante distinta da que ocorria na velha cidade, e a estas noções de espaço são agregadas às experiências por eles vivenciadas. Também, a sua configuração espacial e o seu desenho, com a delimitação de zonas exclusivas e homogêneas de atividade, a concentração das casas, as edificações das atividades coletivas e o novo sistema de tráfego expressam a intenção desta população no desenvolvimento de sua cidade e no convívio de seus moradores, demonstrando o desejo comum em alcançar algum progresso econômico através de uma cidade "do padrão moderno". ${ }^{133}$ (Figuras. 37 e 38).

\footnotetext{
132 "O compadrio, expressão de presença da Igreja Católica na regulamentação das relações familiares, constitui uma rede de relações ancorada nos rituais de batismo e crisma, reinterpretada e ampliada segundo os costumes (ARANTES, 1982). Um dos aspectos que caracterizam esta rede de relações é a criação de laços de solidariedade" (PEREIRA, 1997).

${ }^{133}$ Segundo SEVCENKO (2002), essa percepção de que as mudanças iriam sempre ampliar a prosperidade geral, criar mecanismos re-distributivos e alguma forma de forçar a transparência e a participação, foi o sentido do desenvolvimento das chamadas democracias modernas.
} 
Segundo Helder Naves Torres: "Daqui a 50 anos, a arquitetura de Nova Ponte será estudada como um marco, uma mudança nos padrões do que é executado hoje - será como é Brasília, hoje!"

Para o arquiteto do Departamento de Projetos de Edificações da CEMIG, Ivan da Costa, nas solicitações feitas pela população de Nova Ponte, o padrão arquitetônico a ser adotado não seria o original, mas um "padrão moderno".

As proporções das edificações na nova cidade parecem querer corresponder às proporções da própria cidade. $\mathrm{Na}$ avenida principal, são muitas as edificações de dois pavimentos, tipo de ocupação que na antiga Nova Ponte era exclusiva da Prefeitura Municipal. O afastamento frontal, presente na maioria das edificações na cidade planejada, também, cria uma relação distinta entre o espaço privado e o espaço público diferente da que ocorria na velha cidade, onde as "casas davam para a rua". Hoje, os muros altos e as grades são presença constante na paisagem da cidade.

\subsection{Uma luta organizada: resultados práticos}

Na primeira proposta da CEMIG, o projeto para a cidade nova partiu da idéia de manter a rua principal - traço típico das pequenas cidades do interior mineiro. Essa rua seria transformada em avenida e atravessaria a cidade como seu eixo de circulação, como uma "coluna vertebral" , concentrando os equipamentos de uso coletivo e formando o que seria a "região central"134. Outra idéia que norteava o projeto era a unificação da cidade, que sempre foi cortada pelo rio Araguari e dividida em duas partes de identidades fortemente definidas. A proposta era construir uma nova cidade com aproximadamente 1800 lotes, incluindo os 76 lotes industriais. Esperava-se que os lotes industriais atraíssem os microempresários da região. Toda a cidade seria atendida com redes de eletricidade, água, esgotos, captação das águas

${ }^{134}$ BRANDÃO (1997). 
pluviais, telefonia e contaria com seu total de ruas asfaltadas. Serviços que não eram oferecidos a todos os moradores da velha Nova Ponte. Relata Pe. Júnior: "Nós estávamos vendo que a cidade não ia sair de forma alguma. A questão estava difícil, a viabilização da discussão sobre o que nós gostaríamos para a cidade nova estava difícil. Queríamos as edificações públicas, as casas, tudo o que existia na cidade antiga, mas queríamos melhores. Quando já tínhamos o terreno, onde seria a cidade, queríamos um projeto que mostrasse como essa nova cidade seria".

Em 27 de outubro de 1986, a CEMIG submeteu à aprovação da Prefeitura e da Câmara Municipal, o estudo de relocação urbana da nova cidade. Uma maquete ${ }^{135}$ desse projeto foi apresentada à população de Nova Ponte. A idéia era de que através da maquete a população pudesse compreender melhor como seria a cidade a ser construída. (Figura. 40).

A população através da AMNP negociou com a CEMIG, junto à Prefeitura e a Câmara Municipal, na tentativa de manter a mesma estrutura dos bairros da velha cidade, tentaram manter os antigos moradores em seus respectivos bairros e com a mesma vizinhança, além de tentar manter nos mesmos bairros os comércios de natureza local, unidades escolares, postos de saúde, igrejas, em uma área que poderia ser percorrida a pé. Também foi exigida a construção de um campo de futebol. A opinião dessa população, sobre a primeira proposta apresentada pela CEMIG, foi expressa através de carta, datada de 29 de maio de 1987.

A CEMIG construiu o campo de futebol e um clube social. Também foram acrescidas, além da avenida principal com $14 \mathrm{~m}$ de pista asfaltada, com calçadas laterais de $4 \mathrm{~m}$ e canteiro central arborizado e iluminado, mais duas avenidas, também com $14 \mathrm{~m}$ de pista asfaltada. No projeto final aprovado a cidade contou com seis avenidas e 23 ruas asfaltadas, com dimensões variadas que atenderiam as necessidades segundo as áreas onde forem implantadas. A aprovação desse projeto foi condicionada às alterações e acréscimos, atendendo as solicitações da referida carta elaborada pela

\footnotetext{
${ }^{135}$ A maquete está preservada e se encontra em exposição no Museu Rural de Nova Ponte.
} 
população. Segundo Ivan da Costa, arquiteto da CEMIG: "Eles voltaram as coisas para os lugares originais, quiseram manter a mesma estrutura dos bairros".

A população luta para a construção de uma cidade ideal. Na nova cidade não haveria ninguém fora da escola ou sem moradia, onde todos teriam o direito a uma casa "padrão" - com quarto, sala, cozinha e banheiro. Também, receberiam casa as pessoas que não tivessem a posse da terra e as que pagavam aluguel, principalmente a população que morava em "meia-água" barracos construídos em área da prefeitura ou na beira de córregos próximos, edificados em alvenaria, plástico ou lata de óleo batida e compostos de um ou dois cômodos, sem qualquer infra-estrutura. Relata o Pe. Júnior: "Na época, foi grande a discussão sobre as pessoas que não tinham moradia, viviam de aluguel ou naquelas casas de 'meia-água'. Para que eles pudessem ter uma casa - uma casa 'padrão', que tivesse pelo menos banheiro, quarto, sala e cozinha, alguma infra-estrutura - foi outra luta, mas isso aconteceu. Hoje eu não gosto de voltar à Nova Ponte, não! Não posso entender porque tem tanta gente morando de aluguel. Não era para ter mesmo! Não era para ter ninguém fora da escola, sem moradia, esse processo não foi feito para isso. Mas hoje, estamos vendo também lá, a falta de emprego, educação e saúde".

A própria CEMIG se responsabilizou pelo cadastramento das pessoas que moravam em terreno do município ou na beira dos córregos próximos à velha cidade. A Prefeitura alegou não ter condições técnicas, nem pessoal para efetuar o levantamento dessa população. Segundo Helder Naves Torres: "As pessoas que não tinham a posse e moravam em terreno da Prefeitura ou na beira de córrego foram identificadas pela CEMIG, que posteriormente as indenizou".

A Igreja Católica foi determinante na tentativa de reassentar essa população carente. O pároco da cidade, na época o Pe. Júnior, negociou com a CEMIG um terreno de propriedade da igreja na velha cidade, conseguindo trocá-lo por 180 lotes da cidade nova. Todos os lotes adquiridos com a negociação pelo padre foram entregues à população carente e aos sem a posse da terra. Com a negociação, a CEMIG ficou responsável pela 
viabilização de toda infra-estrutura, como a abertura de ruas, água, esgoto e luz, e a Prefeitura Municipal doou toda a mão de obra e os materiais para a construção das casas. Relata Pe. Júnior: "A igreja tinha uma terra, um bairro na cidade velha, que rendeu 180 lotes na cidade nova. Nós entregamos para o povo aqueles lotes com infra-estrutura total, e a Prefeitura deu toda a mão de obra, como também tijolos e tudo o mais. Depois de 1 ano e meio, esse povo já tinha vendido todas as casas. Isso foi um tanto frustrante e ao mesmo tempo importante, porque nós percebemos que sem uma educação, o povo pode até receber uma casa, mas não adianta... é por um andarilho dentro de uma mansão, sem educação, ele vai continuar agindo como andarilho. O importante é construir uma realidade junto com o povo, junto com eles."

Em 1987, o "Plano Diretor de relocação da Nova Cidade de Nova Ponte" foi submetido à aprovação da população, já com sua respectiva "Planta de Urbanização". Também foi elaborado o "Projeto Final de Infra Estrutura Urbana, Paisagismo e Urbanização da Nova Cidade de Nova Ponte", que foi aprovado pela municipalidade no mesmo ano ${ }^{136}$. Segundo Pe. Júnior: "Nova Ponte é um exemplo vivo de participação que vai ficar para a história. Eu vi surgir um novo povo, que ainda é sofrido - eu vejo isso ainda, quando volto lá! as marcas ainda continuam. Mas com certeza surgiu um povo mais consciente, maduro e participativo quando os deixaram falar, agir e participar de todas as decisões, sobre tudo, ruas, praças, edificações,... tudo!"

Houve resistência de muitos moradores em deixar sua história, seu "lugar". O bairro em que se encontrou maior resistência foi o Bairro de São João. Isso porque, mesmo não correndo o risco de ser inundado, o bairro foi relocado pela CEMIG. O Sr. Sebastião Firmino, trabalhador rural, que se recusava a mudar de casa teve o apoio de vários vizinhos. Para ele, como para os outros tudo ficou mais difícil. Com a construção da represa a distância de seu trabalho para a cidade aumentou de três para dezoito quilômetros, e sua vida simples sofreu uma mudança radical, para a qual nem ele, nem nenhum dos moradores da velha cidade estavam preparados. Em contrapartida, a maioria dos moradores da antiga cidade optou por receber terreno e

\footnotetext{
${ }^{136}$ Lei Municipal no 861 de 06 de julho de 1987.
} 
indenização para a construção de uma nova edificação na cidade atual, a ser indenizado em dinheiro e ter que se mudar para outra cidade.

Na velha cidade de Nova Ponte mesmo com suas ruas esburacadas e a falta de infra-estrutura urbana, seus moradores a reconheciam como o espaço deles. Se esta cidade não tivesse sua morte decretada, ainda hoje estaria em transformação e definindo sua própria história já que, por definição, toda cidade faz uma composição sempre inacabada de sua coletividade. Segundo Pe. Júnior: "Houve uma agressão na vida daquele povo. Uma mudança que foi muito sofrida e nem isso estava sendo respeitado. Tomamos consciência disso e fizemos nossas assembléias para exigirmos a cidade do jeito que a comunidade almejava. Muita gente morreu de sofrimento, de dor mesmo. Muitas pessoas idosas não suportaram a idéia de sair do seu lugar, mesmo indo para uma casa nova. Nada era mais importante do que a história deles. Eu penso que em Nova Ponte, dentro das questões que foram levantadas, como as da construção da cidade, naquele momento o mais importante foi a manifestação popular".

Na definição dos projetos para as edificações públicas, também houve participação da população, que através da AMNP em reuniões com a Prefeitura e a Câmara Municipal, analisaram a viabilidade de cada projeto e a aprovação dos mesmos, como relata Pe. Júnior: "Mesmo nas construções públicas havia a participação da população. Nada se fazia sem que antes houvesse uma reunião entre os vereadores, a associação e a Prefeitura. Depois os projetos eram mostrados para o povo. A população falava quando não queria aquilo e mostrava o que queria. Também analisávamos a viabilidade, pois não adiantava sonhar com o que era improvável naquele momento. Mas o importante é que tudo era feito por votação. Evidentemente, houve erros, mas mesmo assim, eu acredito... o que aconteceu foi o melhor do melhor foi o povo fazendo!" 


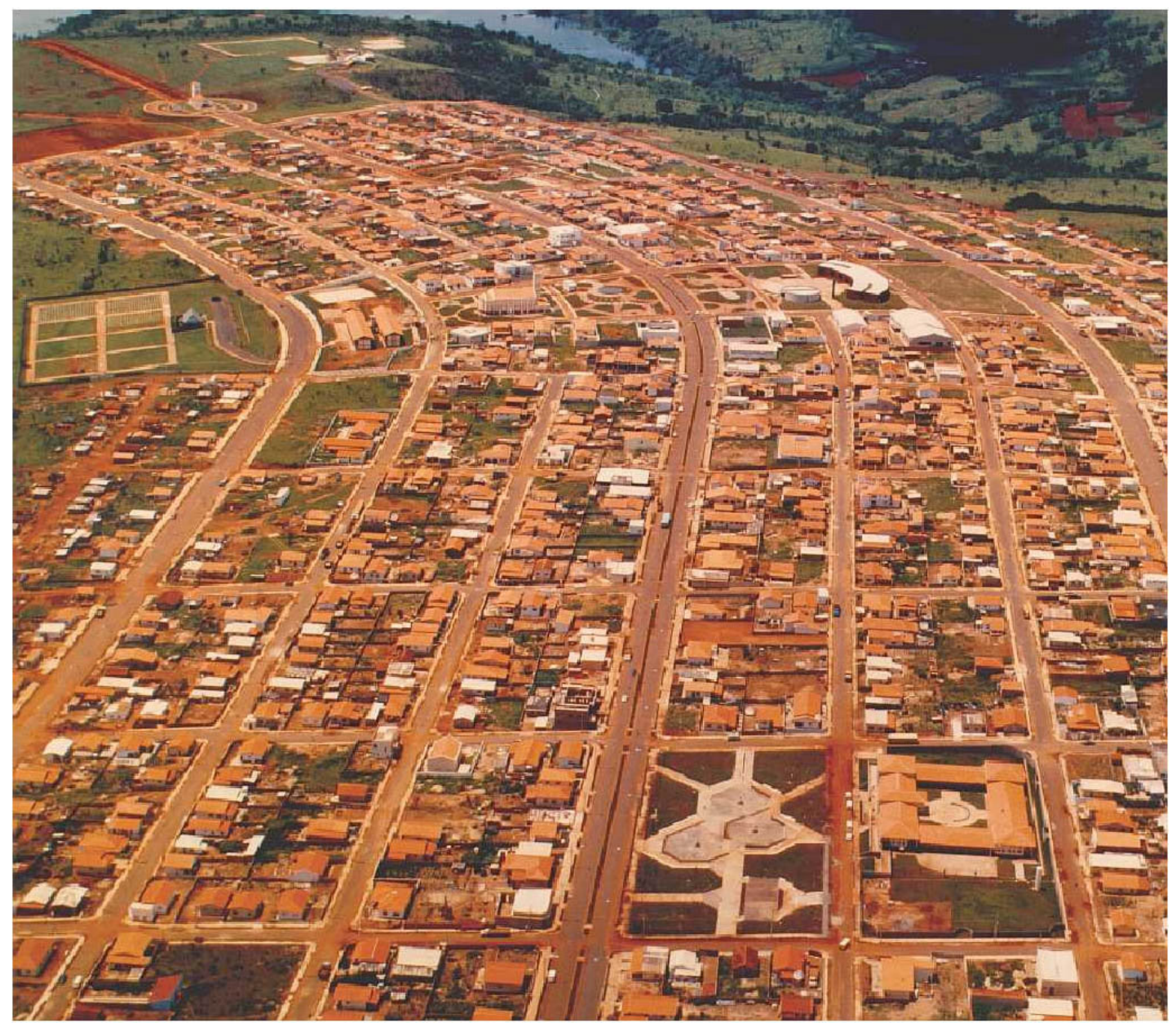

Figuras. 37 e 38 - Fotos aéreas da nova cidade. Fonte: CEMIG - Belo Horizonte.

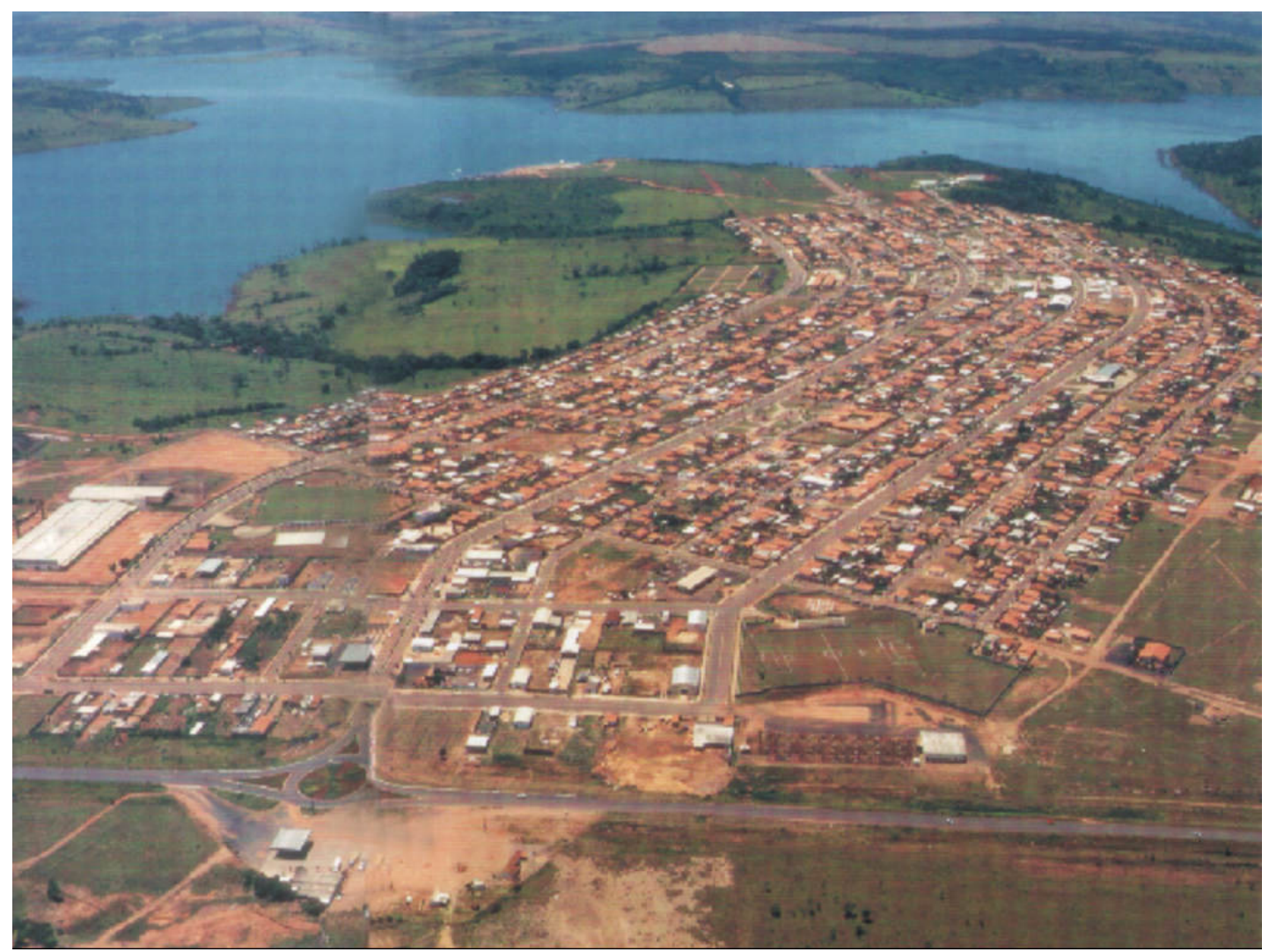




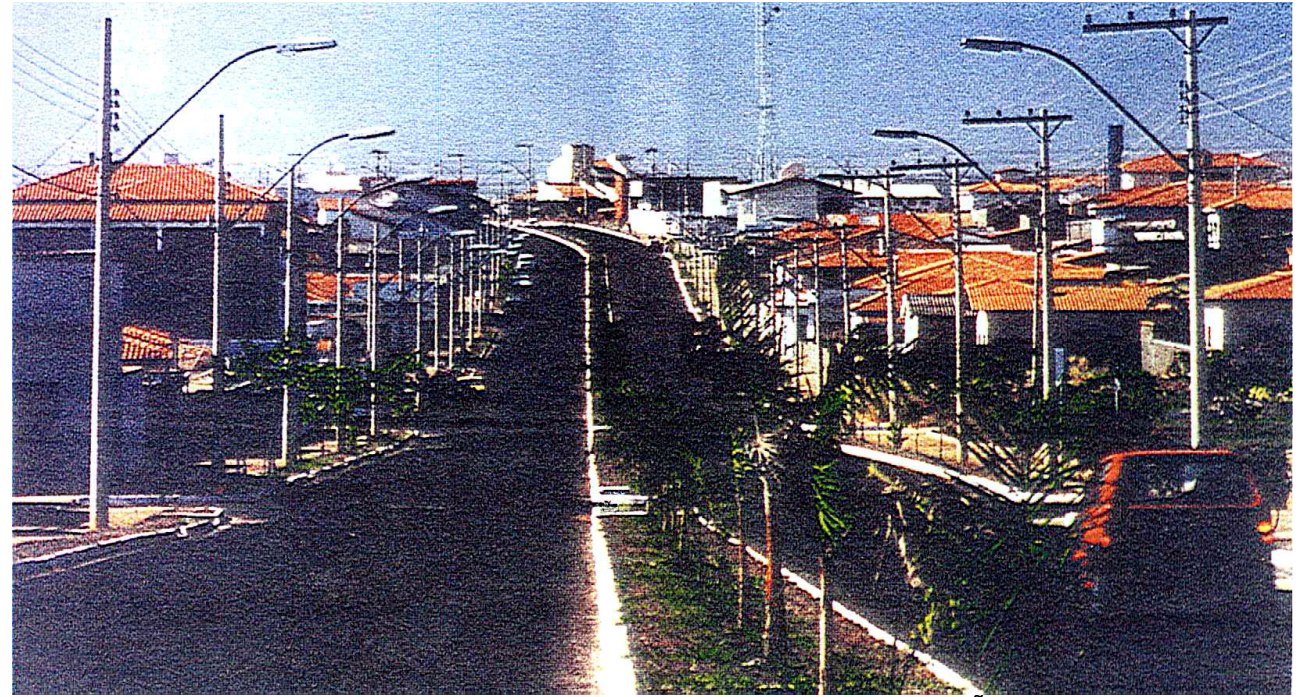

Figura. 39 - Avenida principal da cidade nova. Fonte: BRANDÂO (1997).

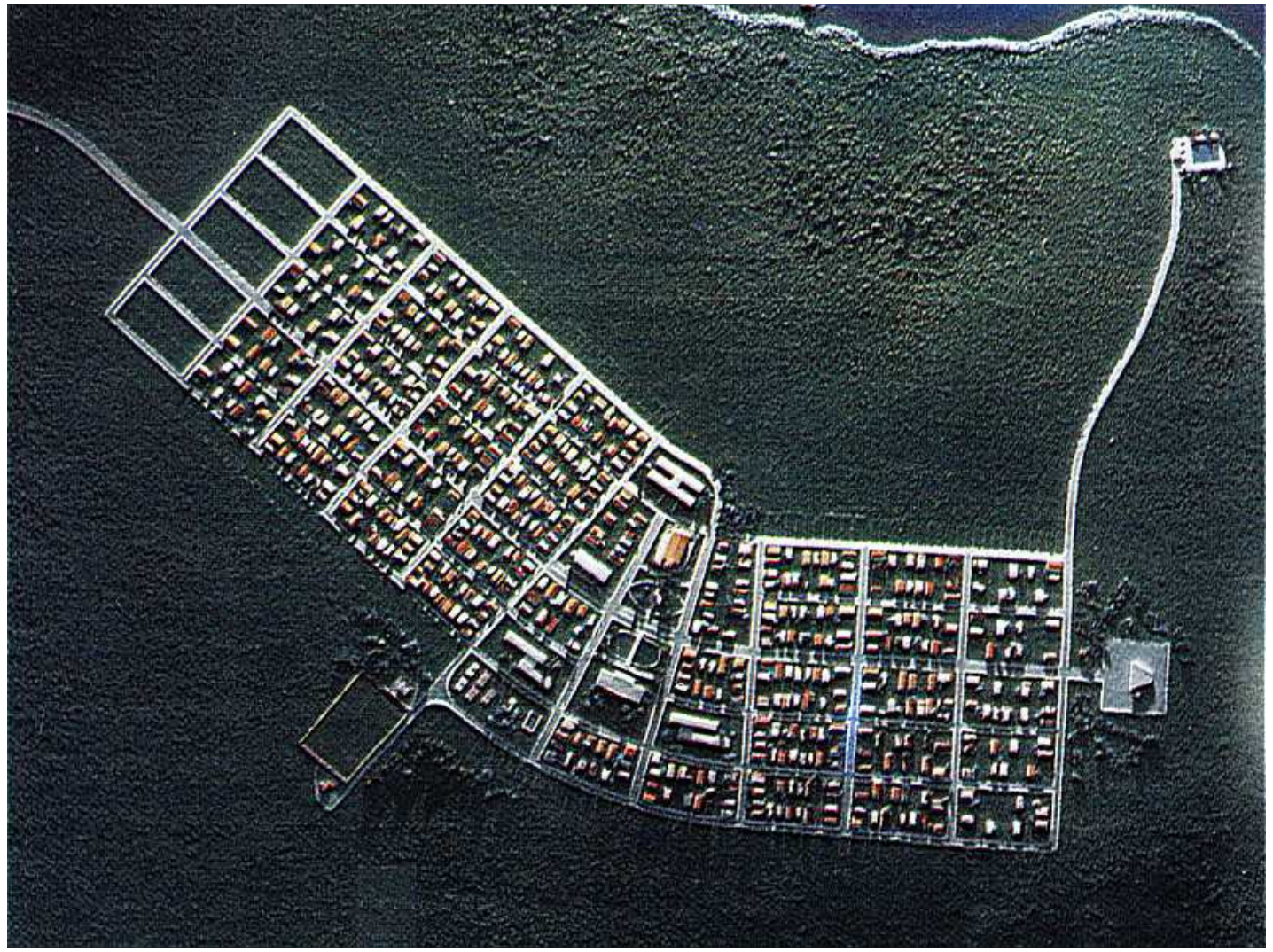

Figura. 40 - Foto da maquete. Fonte: fotografia da pesquisadora. 


\subsection{A atual cidade de Nova Ponte}

A cidade nova foi implantada em uma área alta e plana, localizada à margem direita da rodovia MG-190 e distante 3 quilômetros da antiga sede. $\mathrm{O}$ custo da implantação da cidade foi de US\$ 60 milhões, com sua construção e indenizações pagas pela CEMIG aos expropriados.

A cidade nova é banhada por um lago, formado pelas águas da barragem da UHE Nova Ponte, na confluência dos rios Araguari e QuebraAnzol. O lago possibilita a exploração turística, especialmente no carnaval, na cavalhada e outros eventos culturais, organizados em sua praia, atraindo um grande contingente de pessoas para a cidade, gerando divisas para 0 município e novas oportunidades de emprego para sua população. As ruas foram implantadas de maneira a evidenciar os melhores panoramas do lago, creditando-lhe grande parte dos efeitos estéticos alcançados no projeto urbano.

A CEMIG entregou para a população de Nova Ponte, uma cidade que tem sua área urbana parcelada em quarteirões e subdividida em lotes, que totalizam 1.760 lotes na área residencial, com áreas que variam entre $360 \mathrm{a}$ $375 \mathrm{~m}^{2}$ e 124 lotes na área industrial, com áreas médias de 500 a $1300 \mathrm{~m}^{2}$. Os lotes na cidade nova foram planejados para atender às variações do uso, das formas de propriedade, da natureza e dos tipos de construção. Quanto à forma, é visível a preferência por lotes retangulares, com fundos duas vezes superiores à testada, exceto na área industrial.

A localização dos bairros residenciais é adequada às características topográficas, a facilidade para a construção e ao funcionamento dos serviços públicos, como escolas e postos de saúde. A infra-estrutura de toda a cidade é completa, contando com $100 \%$ de rede elétrica, iluminação pública, abastecimento de água tratada, drenagem de águas pluviais, coleta e tratamento de esgoto.

A localização do setor industrial obedeceu a uma distância razoável dos bairros residenciais e se localiza nas proximidades do trevo de acesso à cidade, propiciando maior facilidade no escoamento de bens e produtos. A área 
industrial foi projetada para abrigar pequenas indústrias e grandes equipamentos de comércio e serviços.

\subsubsection{Localização Geográfica ${ }^{137}$ (Figura. 41).}

A cidade de Nova Ponte com latitude de 1991'54" sul, longitude de 47\%43'38" oeste e altitude média de 930 metros acim a do mar, situa-se entre as principais cidades da região do Triângulo Mineiro e Alto Paranaíba, como Uberaba, Uberlândia, Patrocínio, Patos de Minas e Araxá.

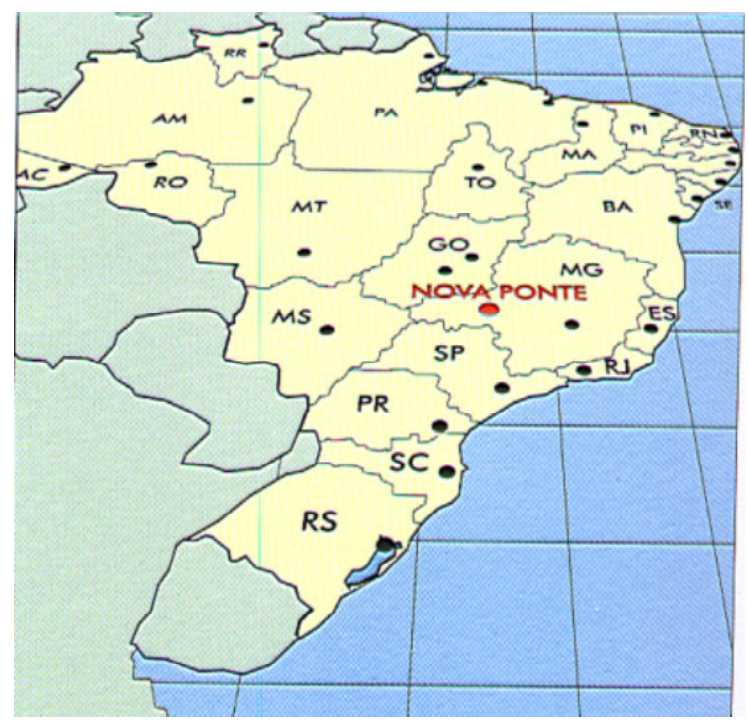

Figura. 41 - Mapa de localização geográfica da nova cidade de Nova Ponte. Fonte: Prefeitura Municipal de Nova Ponte.

${ }^{137}$ Dados obtidos na Prefeitura Municipal de Nova Ponte. 


\subsubsection{População}

Tabela 10. Distribuição da população municipal (2003).

\begin{tabular}{l|c}
\hline Distribuição & № de habitantes \\
\hline Urbana & 12.620 \\
Rural & 2.228 \\
\hline Total & 14.848 \\
\hline \multicolumn{2}{c|}{ Fonte: Prefeitura Municipal de Nova Ponte. }
\end{tabular}

\subsection{3. Área Municipal}

Tabela 11. Distribuição da área municipal (2003).

\begin{tabular}{l|l|l}
\hline $\begin{array}{l}\text { Divisão da área por } \\
\text { ocupação }\end{array}$ & $\boldsymbol{K m}^{\mathbf{2}}$ & $\%$ \\
\hline Área urbana & 3,82 & 0,34 \\
Área de reserva natural & 47,85 & 4,32 \\
Área de reflorestamento & 108,00 & 9,74 \\
Área de soja & 220,00 & 19,85 \\
Área de milho & 230,00 & 20,75 \\
Área de pastagem & 418,00 & 37,71 \\
Área da usina (inundada) & 46,24 & 4,17 \\
Outras & 34,59 & 3,12 \\
\hline Total & 1108,50 & 100,00 \\
\hline
\end{tabular}

Fonte: Prefeitura Municipal de Nova Ponte.

\subsubsection{Equipamentos e serviços}

A cidade planejada de Nova Ponte oferece atendimento médico na área urbana e rural, e conta com: 6 clínicas odontológicas, sendo 2 municipais; 2 postos de saúde, um na cidade e outro no povoado de Almeida Campos; 1 hospital com 23 leitos (Figura. 42), centro cirúrgico, pronto-socorro, raios-X, Laboratório e demais serviços; 1 clínica de fisioterapia. 


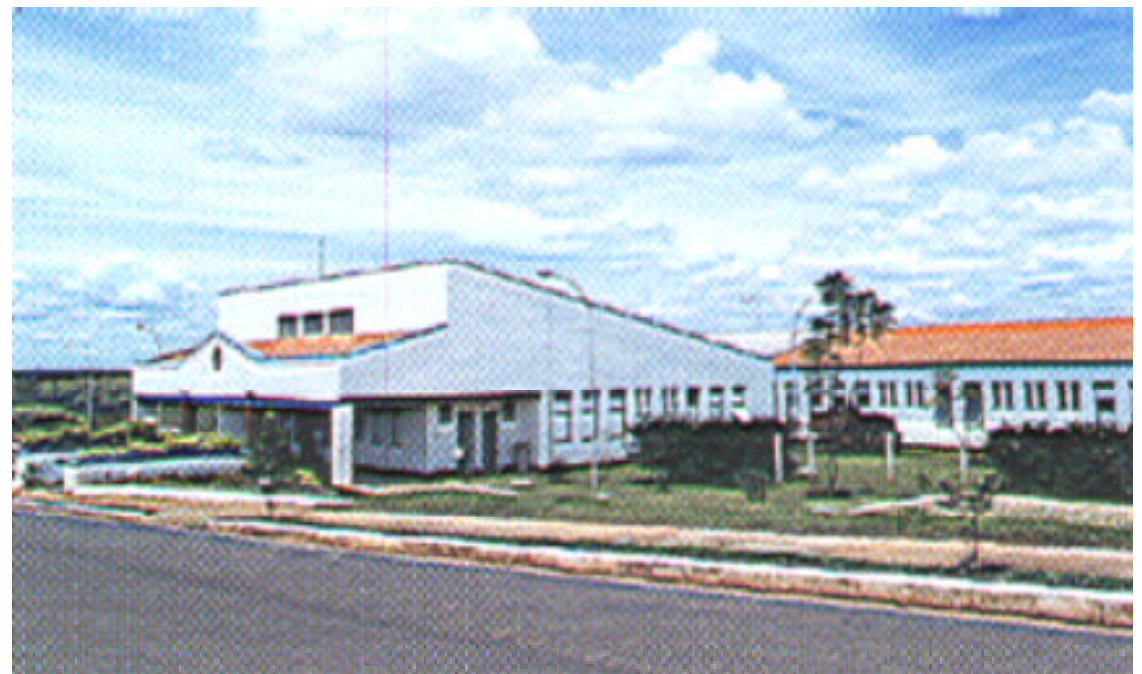

Figura. 42 - Hospital Municipal da atual cidade. Fonte: Prefeitura Municipal

\subsubsection{Educação, lazer e esporte}

Atualmente, a nova cidade possui: 6 escolas de ensino fundamental com 1.906 alunos matriculados; 1 escola de ensino médio e cursos técnicos (contabilidade e magistério) com 1.300 alunos; 1 centro social urbano e 1 ginásio poliesportivo; 3 núcleos escolares localizados na zona rural com transporte escolar gratuito. Além disso, a Prefeitura Municipal de Nova Ponte oferece transporte gratuito e algumas bolsas de estudo para universidades de Uberaba e Uberlândia.

\subsubsection{Infra-estrutura}

$\mathrm{Na}$ área de infra-estrutura urbana, a nova cidade apresenta um quadro positivo: 99\% de suas residências são atendidas com asfalto, água e esgoto tratados e energia elétrica. Incluindo a área rural, Nova Ponte conta com 680 linhas telefônicas, além das imagens de 4 emissoras de televisão e 2 rádios. Há a circulação de jornais esporádicos. Para sua segurança a população conta com: 1 quartel de Polícia militar; 1 delegacia de Polícia Civil; Polícia Rodoviária e Polícia Florestal. 


\subsubsection{Transporte}

Nova Ponte tem uma boa rede rodo ferroviária e está inserida em três corredores de exportação e importação ligados aos principais portos do país. Pela rede rodoviária, a cidade está interligada às rodovias: MG-190 e BR-050, 262, 365 e 452. Vindo de São Paulo, a ferrovia R.F.F. A-SR2 passa por Nova ponte, e pelo povoado de Almeida Campos, com destino à Belo Horizonte MG. De Belo Horizonte, segue via Vale do Rio Doce até Vitória - ES, para o Porto de Tubarão. Conta ainda com 1 aeroporto de extensão 1500 m e pista asfáltica para aeronaves de grande porte. (Figura. 43 e 44).

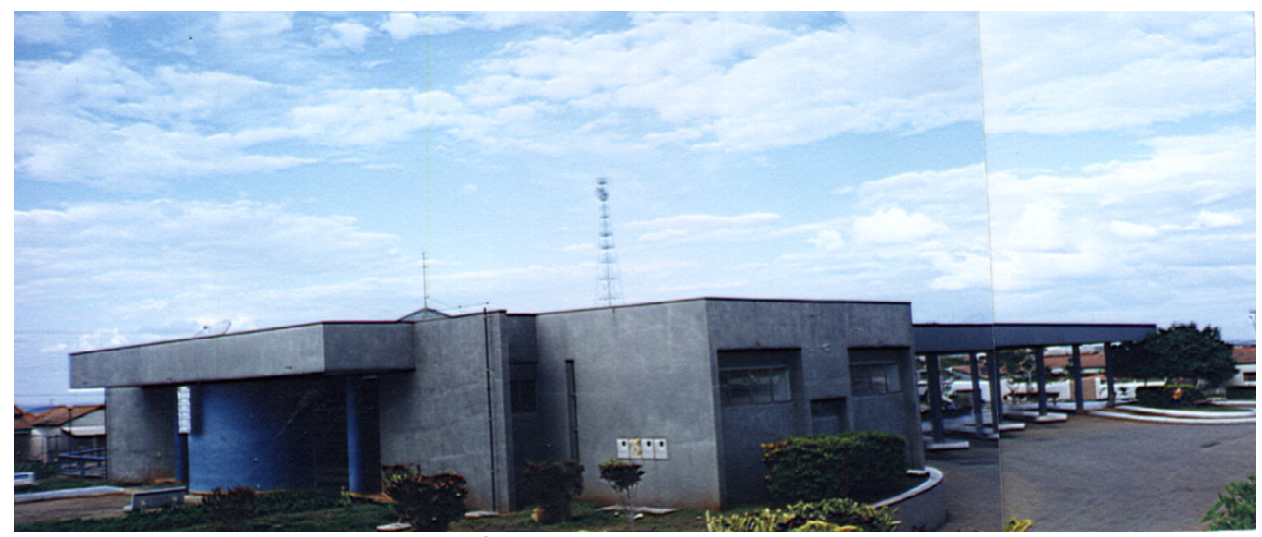

Figura. 43 - Rodoviária da nova cidade. Fonte: fotografia da pesquisadora.

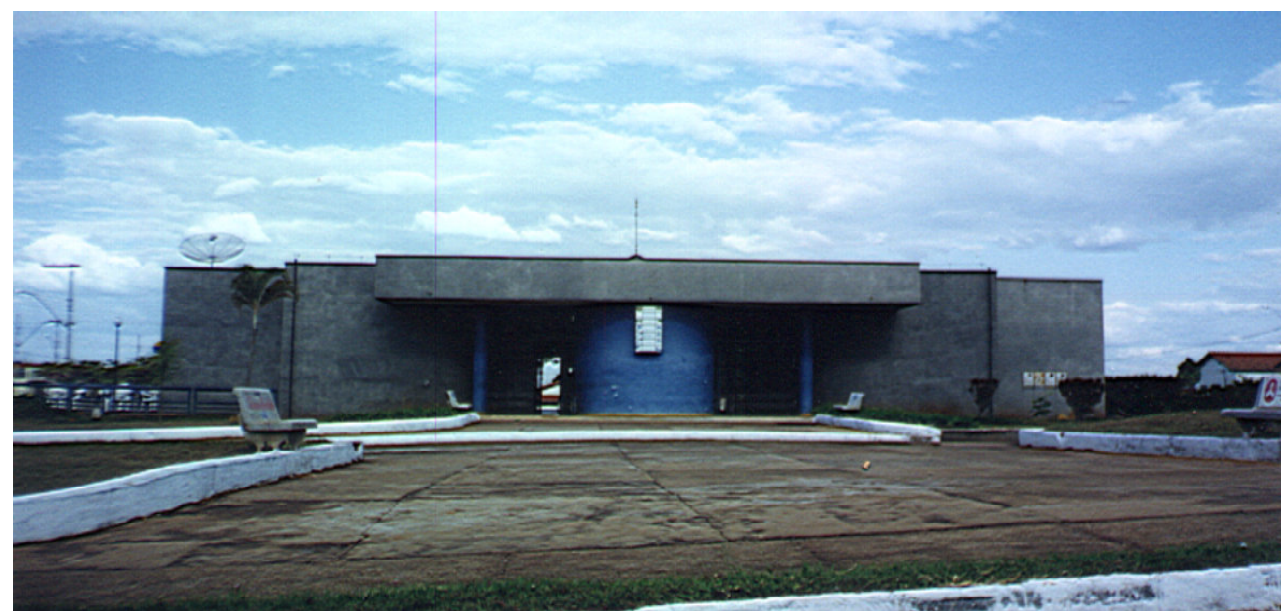

Figura. 44 - Fachada da rodoviária. Fonte: fotografia da pesquisadora 


\subsubsection{Atividades econômicas do município}

$\mathrm{Na}$ agropecuária a área plantada de cultura representa $41 \%$ de sua área total. O plantio de café, feijão, arroz e hortifrutigranjeiros também merecem destaque. A avicultura tem uma produção representativa, com $33900 \mathrm{~m}^{2}$ de granjas construídas e em atividade, totalizando uma produção de 2440800 frangos/ano. A pecuária apresenta um plantel de aproximadamente 30 mil cabeças de gado bovino. Sua produção leiteira é da ordem de 35 mil litros/dia.

Nova Ponte conta com 186 estabelecimentos comerciais, 2 agências bancárias, 6 indústrias de médio porte, 2 indústrias de médio à grande porte.

O Triângulo Mineiro possui os principais reflorestamentos de pinus do estado. A área plantada com pinus, de idade de 8 a 12 anos é de 93 mil hectares, desse total 10,8 mil hectares estão plantados em Nova Ponte.

A Usina Hidrelétrica de Nova Ponte é responsável pela geração de 510 megawatts de energia que representa todo consumo do Triângulo Mineiro. Sua barragem possui 1600 metros de comprimento, uma altura de 142 metros e o atual lago apresenta uma extensão de $443 \mathrm{Km}^{2}$.

\subsection{A apropriação da nova cidade por seus velhos personagens}

A primeira obra inaugurada na nova cidade de Nova Ponte foi o cemitério do município, o novo Cemitério de São Miguel (Figura. 45), construído pela CEMIG. A implantação do cemitério teve lugar em uma área cercada com placas de cimento pré-moldado, onde foi fixada uma cruz de madeira.

O Cemitério de São Miguel foi "edificado" com a autorização da Prefeitura Municipal de Nova Ponte, entretanto, sua construção contrariou a decisão da população quanto à sua área de implantação. $O$ cemitério foi construído dentro da área urbana e central na cidade nova. Relata Pe. Júnior: 
"Infelizmente ainda existem aqueles que usam da situação e se favorecem do momento, para tirarem proveito. O terreno onde foi construído o Cemitério São Miguel, era de algumas pessoas líderes na época. Eles cercaram o cemitério em janeiro de 1987, o prefeito autorizou tal construção sem a participação dos moradores, mas totalmente vinculado a CEMIG. Uma das nossas discussões, que ainda estava em curso, era para que o cemitério não fosse construído dentro da cidade. No projeto da cidade nova, que ainda estava em discussão, o cemitério era para ser fora da cidade, acho que não tivemos a visão de que ficaria tão central como ficou".

Os moradores membros da AMNP chegaram à conclusão de que estava havendo algum tipo de manipulação em favor de alguns líderes políticos do município, segundo Pe. Júnior: "Chegamos à conclusão, de que alguns dos líderes políticos na época, de certa forma, estavam sendo comprados para aceitarem as imposições que vinham de cima, do governo estadual. Percebendo isso, nós começamos a 'abrir os olhos' e acompanhar de perto todo tipo de verba que chegasse na cidade. De certa forma, tudo deveria ser decidido e negociado com a associação, nem tanto com a Prefeitura ou com os vereadores. Em 87, quando cheguei de férias, encontrei todo o povo falando da inauguração daquele cemitério. Eu logo fui ver. Na manhã seguinte, a primeira coisa que fiz foi ir para o microfone da igreja e convocar a população. Em menos de duas horas enchemos três ônibus, subimos para a cidade nova onde é a cidade hoje -, e derrubamos o cemitério. Estavam presentes o prefeito e alguns vereadores. O muro de pré-moldado era só empurrar e ele caía. Naquele momento, houve uma grande discussão com o prefeito, exatamente por ele ter desrespeitado a vontade do povo, a vontade da associação, que representava o povo. Derrubamos para mostrar que não era assim que se fazia. Fizemos a pressão para ele rasgar a licitação daquela obra que seria a primeira obra completa da nova cidade. Mas quanto à localização, isso já não tinha mais jeito!"

Hoje, o Cemitério de São Miguel possui uma capela ecumênica, tem suas lápides plantadas no chão iguais para todos, tendo sua paisagem como a de um jardim (Figuras 45 e 46). As 495 sepulturas registradas no antigo Cemitério de São Miguel foram estudadas e catalogadas pelo Projeto Memória 
de Nova Ponte e os restos mortais, posteriormente, translados para novo cemitério na nova cidade: "Estudados os diversos túmulos existentes, compreendeu-se uma evolução de sua arquitetura na medida em que se diagnosticou o predomínio de certas tipologias conforme a década" (BRANDÃO, 1997, p.72-73).

Segundo esse levantamento a velha cidade contava com dois cemitérios: o primeiro cemitério da cidade de Nova Ponte era localizado próximo à antiga capela de São Miguel, e o outro era o cemitério dos Bexigosos ou o cemitério das Lascas, que recebeu esse nome porque era demarcado com uma cerca de lascas de aroeira. O cemitério dos Bexigosos foi fundado no final do século XIX apenas para receber as vítimas de uma epidemia de varíola. A data exata da fundação do cemitério de São Miguel nunca foi precisa, mas sua mais antiga sepultura data de 1891: Em 1923, com a criação do município de Nova Ponte, o cemitério de São Miguel foi regulamentado pelo poder municipal. Nesta data foram fixados os critérios para o seu funcionamento, os quais prevaleceram até 1987, ano em que, devido à futura transferência da população de Nova Ponte, foi determinada a proibição de sepultamentos em sua área “ (BRANDÃO, 1997, p.72-73).

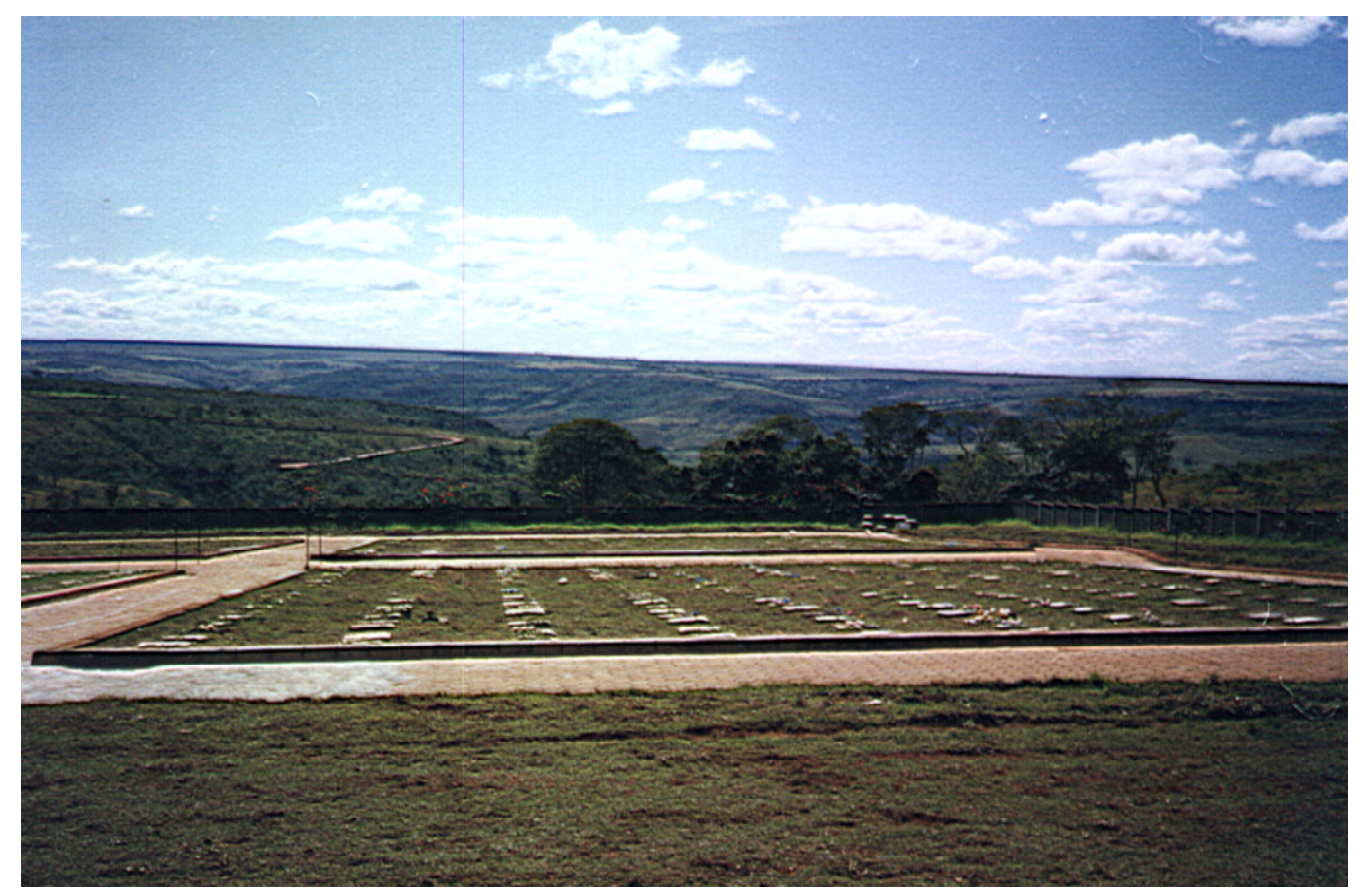

Figura. 45 - Cemitério São Miguel na nova cidade. Fonte: fotografia da pesquisadora. 


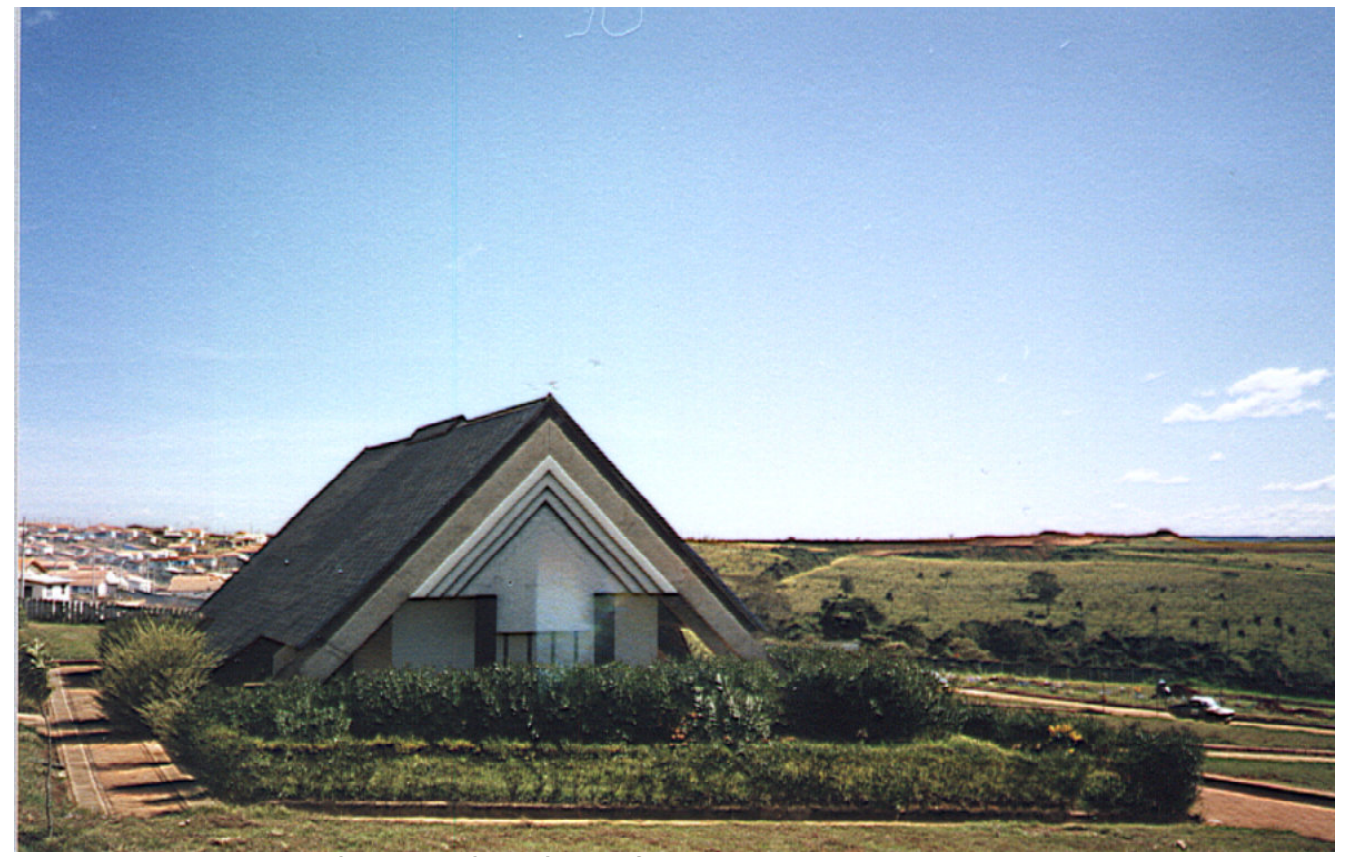

Figura. 46 - Capela do Cemitério de São Miguel. Fonte: fotografia da pesquisadora.

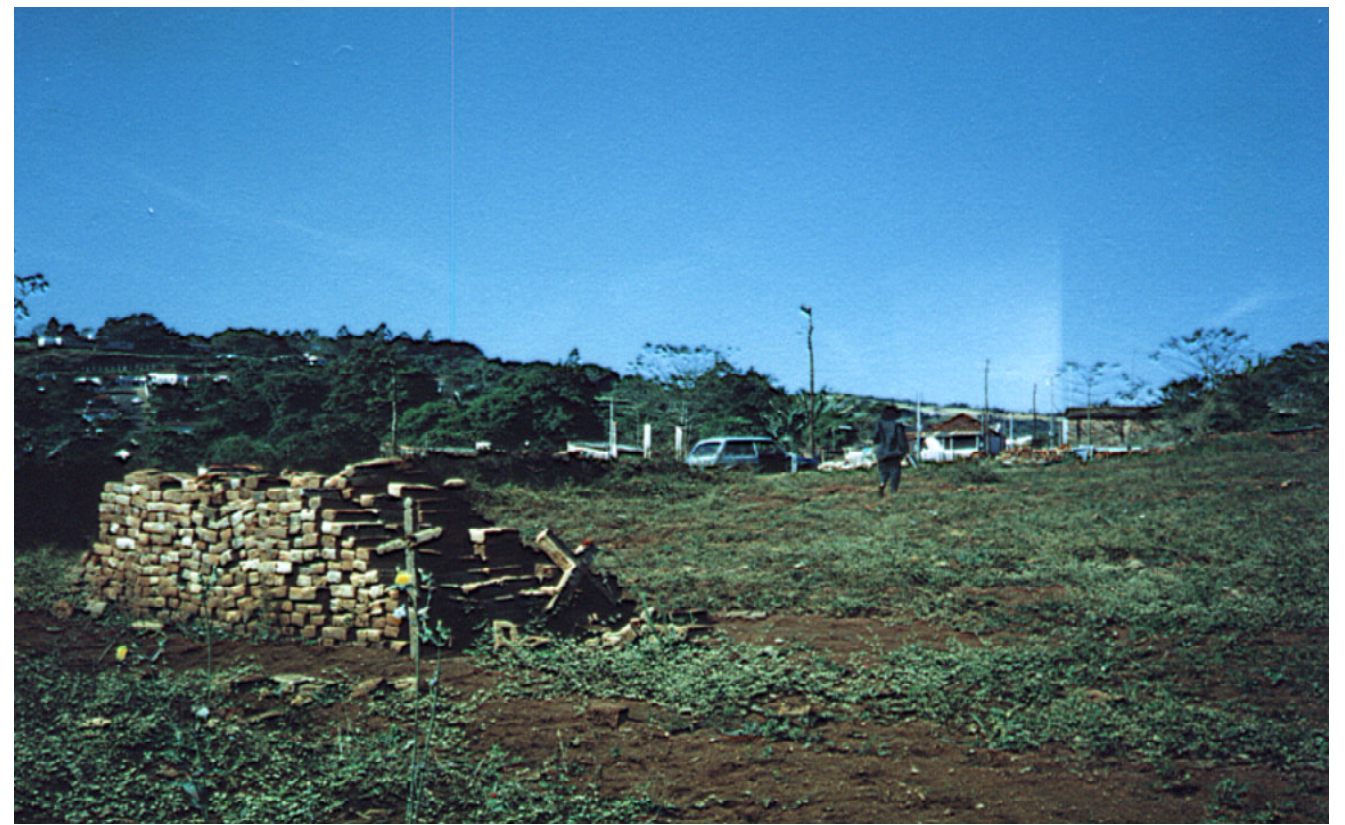

Figura. 47 -O desmanche do velho cemitério São Miguel. Fonte: fotografia da pesquisadora. 


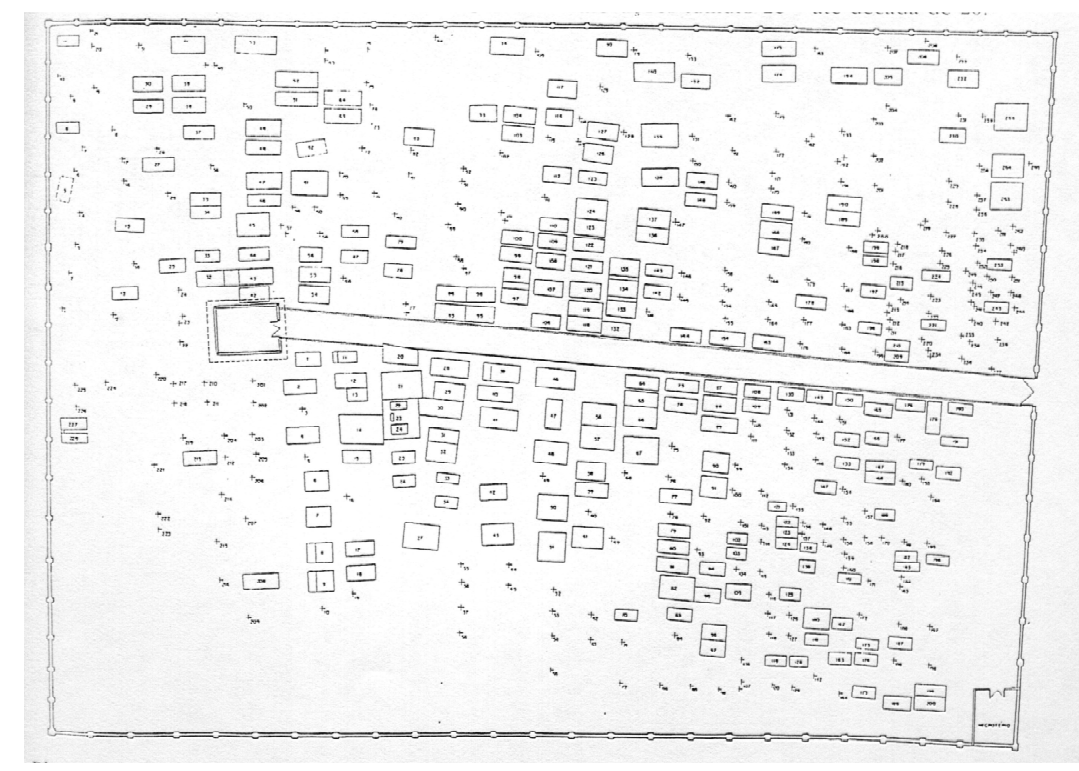

Figura. 48 - Planta do Cemitério de São Miguel da velha cidade. Fonte: Memória e História de Nova Ponte (1987-88)

A Igreja de São Sebastião na nova cidade guarda uma enorme semelhança com a velha igreja. O pedido dos moradores da velha cidade era o de que a arquitetura da igreja a ser construída guardasse as mesmas características do antigo templo. O desejo comum da construção de uma réplica dessa igreja na nova cidade pode ser explicado através dos relatos que compõem a história da Igreja de São Sebastião. A construção data do final do século XIX, e teve a colaboração da população de Nova Ponte. A Igreja representa uma parte importante na memória viva do povo de Nova Ponte, como registram as narrativas ${ }^{138}$ :

"A primeira capela de São Sebastião foi meu avô quem construiu, com donativos. Foi ele também quem buscou em São Paulo as imagens de São Benedito, Santo Antônio e São Sebastião para a Igreja". Contava Luíza Borges de Faria e completava Guiomar Carneiro: "A primeira Igreja era de madeira com assoalho alto"

138 Depoimentos de época, arquivados no Arquivo Público de Nova Ponte para o Projeto Memória de Nova Ponte. 
Em 1930, houve a demolição da Igreja descrita acima e no mesmo local foi construída outra, segundo Maria Jacinta Fernandes: "... depois fizeram outra igreja, maiorzinha um pouco, mas singela também. Ela tinha torre. À frente dela era da espécie da frente do chalé ${ }^{139 " .}$

Segundo Ubaldo Damásio: "A Igreja era uma construção do tipo chalé. Tinha uma escada que levava até o sino. Ela não tinha torre. Tinha os esteios de madeira. $O$ altar era de tijolo. A parte da frente também era de madeira. $A$ parte de trás era redonda, em meia-lua."

Em 1950 há uma nova demolição e em 1951 é que foi construída a Igreja que permaneceu em funcionamento até a inundação da cidade. Segundo Ariovaldo Caldeira de Rezende: "Eu lembro da construção da Igreja nova. Foi na época do Padre Panfílio, que ela foi construída. Ela foi empreitada por um senhor, o Florêncio Fernandes. A empreitada toda custou 80 contos de réis. A gente fez mutirão também. Lembro quando o Florêncio colocou a pedra fundamental. Ele pegou uma latinha de leite ninho, lavou e colocou no rumo da torre, assim no meio da base da torre - onde foram guardadas as mensagens escritas pelo povo. O mesmo projetista ${ }^{140}$ que fez a de São Miguel foi da de São Sebastião. Foi Rafael Verri, o construtor. Eu e meu pai, José Damásio, que trabalhamos. A planta já tinha os ornamentos. O padre fez o desenho da rosácea e meu pai fez a forma. Os vidros vieram de São Paulo".

Relata Caliméio Bernardes: "Eu acompanhei a construção dessa Igreja, viu? Doei umas pedras - pedra tapiocanga da fazenda do meu filho. Todo mundo participou da construção. Eu fui o 'padrinho da pedra'. Cada um dava uma contribuição. Foi assim!".

Segundo o antigo zelador da Igreja de São Sebastião, no dia 20 de janeiro de 1955, dia de São Sebastião, a igreja foi inaugurada: "Quando inaugurou a Igreja, o largo ali encheu de gente. Foi uma beleza de festa aquela!".

\footnotetext{
139 "Chalé" faz referencia ao atual Chalezinho que abriga o Arquivo Público de Nova Ponte.

140 A planta da Igreja de São Miguel foi desenvolvida pelo Pa. Jerônimo Viel, um padre holandês que morava em Romaria.
} 


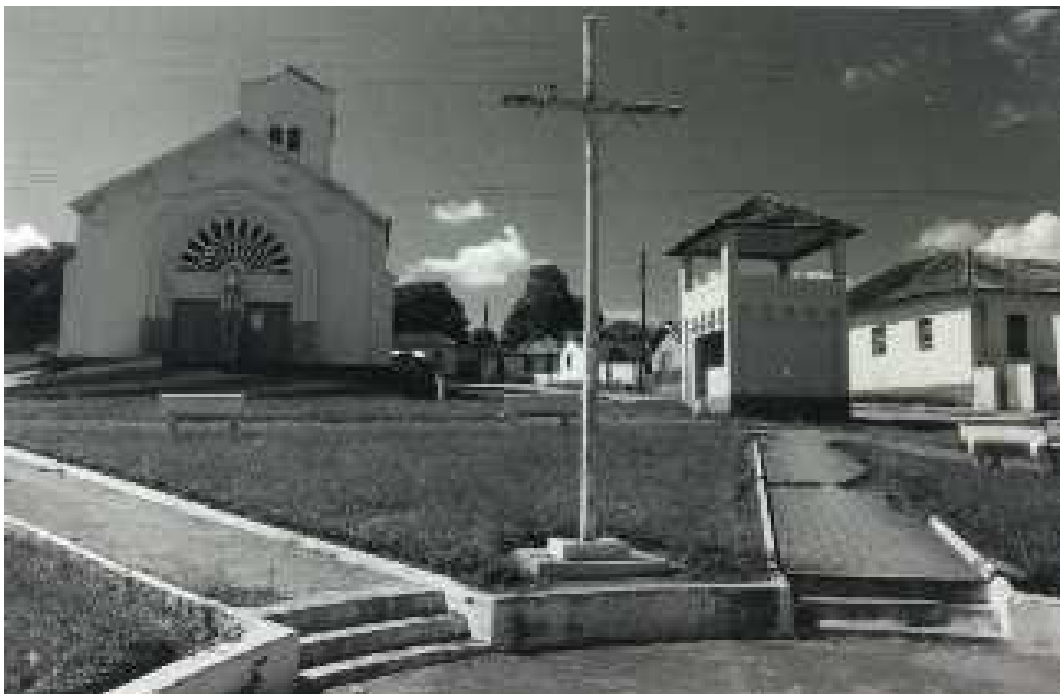

Figura 49 - Igreja de São Sebastião na velha cidade. Fonte: Memória e História de Nova Ponte (1987-88).

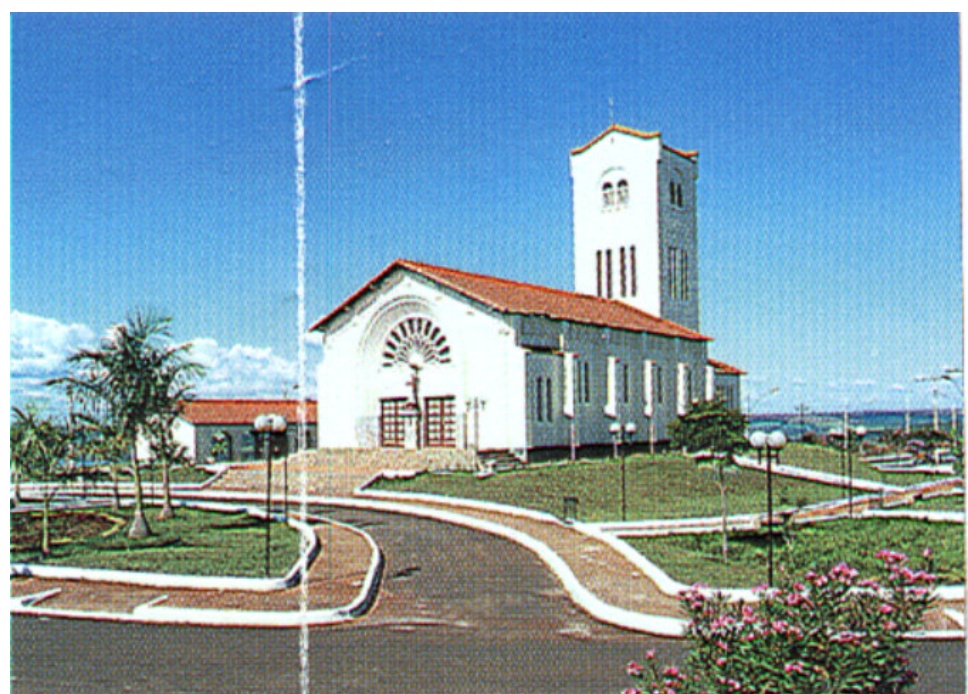

Figura. 50 - Igreja de São Sebastião na nova cidade. Fonte: Prefeitura Municipal de Nova Ponte (1987-88) 


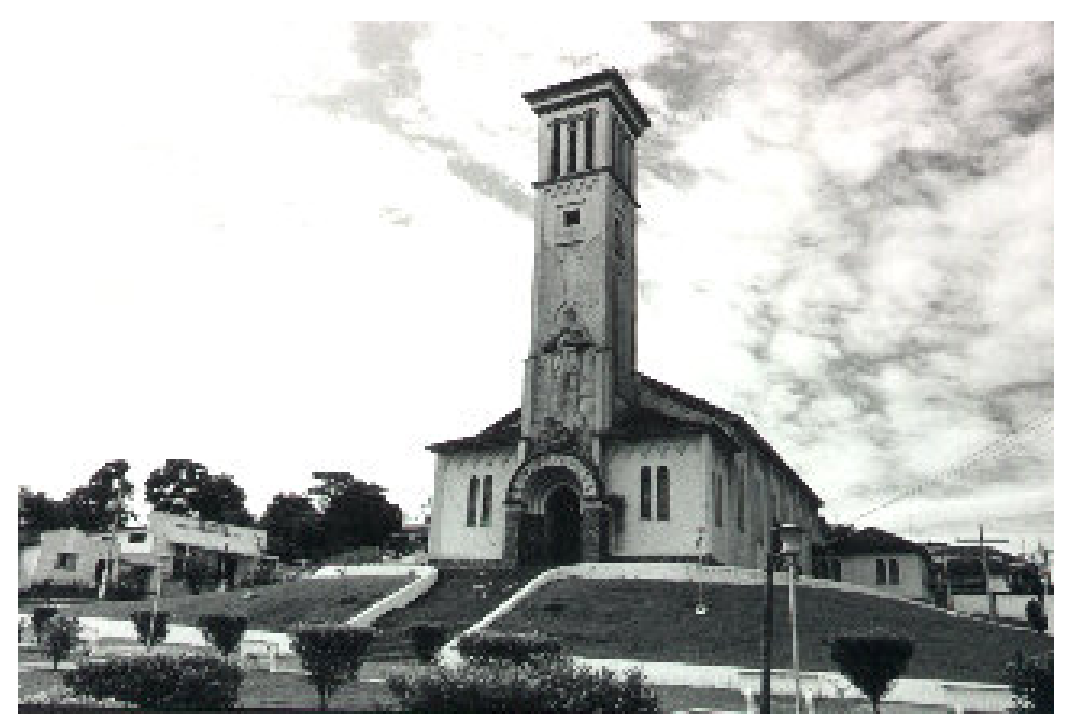

Figura. 51 - Igreja de São Miguel na velha cidade. Fonte: Memória e História de Nova Ponte(1987- 88).

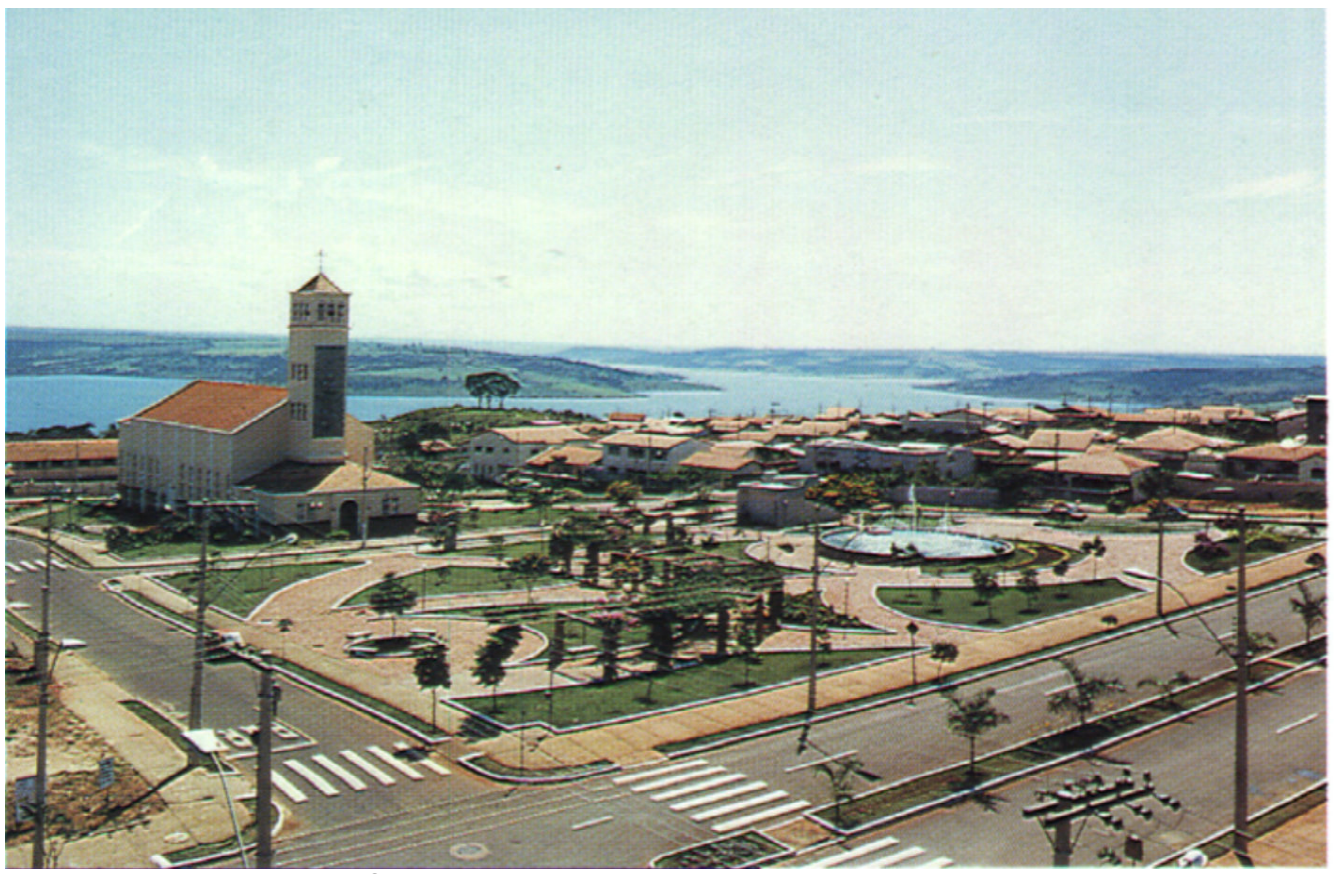

Figura 52 - Igreja de São Miguel na cidade nova. Fonte: Prefeitura Municipal de Nova Ponte. 
A população de Nova Ponte desejava que as igrejas guardassem semelhança com as que existiam na velha cidade. $O$ fato de terem rejeitado um projeto arrojado de Oscar Niemeyer para a Igreja de São Miguel, reforça a intenção da população. Relata o Pe. Júnior: "Eu escrevi uma carta para o arquiteto Oscar Niemeyer, contando pelo que estava passando o povo de Nova Ponte. Em resposta, ganhamos o projeto para a lgreja Matriz. Fui ao Rio de Janeiro, buscar. Ele me deu o projeto de uma igreja com o formato de uma mão e sobre essa mão, tinha uma espécie de nave. A idéia era dizer que a mão de Deus protegia a cidade. E água de um lago, representava o rio que cobriu a cidade velha. Esse projeto foi rejeitado pela população e foi doado para a paróquia de Pedrinópolis, uma cidade próxima dali" ${ }^{141}$.

Segundo o relato de Aparecida Palmieri Torres, os plebiscitos para a escolha dos projetos das igrejas a serem construídas na cidade nova, foram executados de maneira simplista e o resultado, que pode até ter apontado para a manutenção das igrejas como sempre foram, no final das obras não agradou a maioria dos moradores: "A votação sobre o projeto da lgreja Matriz, por exemplo, foi na Praça São Miguel, onde o padre apenas abriu o projeto e perguntou se queríamos aquele projeto. Assim sem muita exposição. Logo a maioria preferiu manter a arquitetura da velha igreja".

Os projetos não foram executados como nos projetos originais que foram acordados entre a prefeitura, a câmara, a AMNP e a CEMIG, e sem nova consulta à população da cidade, sofreram alterações durante as obras. A igreja Matriz, por exemplo, teve o local de sua implantação alterado, como relata Pe. Júnior: "Nós fizemos duas igrejas na cidade nova, a de São Sebastião e a de São Miguel, como existiam na cidade velha. Mas a de São Miguel - a Matriz -, não ficou nada igual. Eu fui transferido de Nova Ponte em janeiro de 92. Eles esperaram que eu saísse da cidade, mas deixei os projetos das igrejas assinados. Meu sucessor chegou. Um padre novo, como eu quando cheguei lá, de certa forma inexperiente... Mudaram a área da prefeitura e colocaram invertida com a da igreja. A igreja era para estar no centro da cidade, na parte alta, onde está a prefeitura. Um desrespeito com o povo de lá, que já tinha

\footnotetext{
${ }^{141}$ Esse projeto de Oscar Niemeyer nunca foi executado.
} 
decidido assim. A igreja também não ficou tão semelhante como era esperado. $A$ velha igreja era muito bonita, em estilo holandês e a população da cidade a queria assim, mesmo estando fora do padrão de uma cidade nova. Aquela população sofrida, ainda sofreu com essas mudanças... é a ausência da história deles" ${ }^{142}$.

Na velha Nova Ponte, a Igreja de São Miguel - a Matriz - e sua praça em frente à Igreja - o 'jardim' - criava uma relação particular entre o espaço público e o privado. Havia "lugares específicos" dentro daquele espaço público (Figuras. 51 e 52). A mudança para a nova cidade alterou definitivamente 0 modo de apropriação e uso desse espaço. $O$ desejo de manter a semelhança da velha Igreja no "novo lugar", reflete o desejo da manutenção de velhos hábitos dos moradores na constituição desse espaço público. Outro fator de relevância está na própria história de participação dessa população na construção da Igreja. A história da edificação se mistura à da vida dos narradores e assim, contam a história da cidade. A tentativa de se construir, na nova cidade, mantendo a semelhança dos templos da velha cidade, sugere que a história dessa construção não pode ser desvinculada da história tanto da cidade que desapareceu, enquanto origem de todo o processo de construção da atual, quanto da própria cidade nova.

Através de algumas narrativas de moradores da velha cidade, é possível a construção de um breve histórico sobre a construção da Igreja de São Miguel.

Uma capela, datada do terceiro quartel do século XIX, foi demolida para dar lugar a Igreja de São Miguel que foi erguida no final do século XIX. Em 1908, a igreja recebeu duas torres laterais que suas fundações não suportaram. Na década de 30 , as torres foram retiradas e um coreto foi construído ao lado. Segundo D. Jorgiana Evangelista Fonseca: "Minha irmã

\footnotetext{
142 "A grande maioria dos projetos dos equipamentos urbanos construídos na cidade nova cerca de 30 , dentre os quais alguns não existentes na cidade antiga - foi elaborada também pelo Departamento de Projetos de Edificações da CEMIG, com a participação da comunidade através de seus representantes. Para a sua elaboração, a equipe da CEMIG consultou os órgãos municipais, estaduais e federais pertinentes, os quais forneceram o programa básico para cada equipamento. Com algumas modificações, todos os projetos foram aprovados, após serem analisados pelo Departamento Municipal de Obras Públicas e pela AMNP, e finalmente referendados pela Câmara Municipal e demais órgãos envolvidos" (BRANDÃO, 1997).
} 
Biquita foi batizada na igreja sem torre. Eu fui batizada na igreja de duas torres".

$\mathrm{Na}$ década de 50, houve uma mobilização da população para a construção de uma igreja maior e mais imponente. A mudança do Pa. Panfílio para Nova Ponte iniciou a mobilização popular. Em 1956, foi demolida a igreja antiga e se fixou a pedra fundamental da nova igreja. Segundo Ubaldo Damásio $^{143}$, os moradores da velha cidade de Nova Ponte colaboraram para que as obras da igreja fossem realizadas: "Fizeram a planta no rascunho. Nós demolimos a outra e daí começou a construção. O padre Jerônimo ia acompanhar a obra. Para construir a lgreja, o terreno não foi desterrado, ele já estava plano. Nós só acertamos a terra, depois fizemos as marcações das fundações e furamos. Quando fui fazer as valetas do alicerce, achamos um formato de caixão, dentes - uma arcada perfeita - colares de pérola... $O$ alicerce foi feito com pedra tapiocanga que a gente tirou do próprio terreno. Os pilares foram feitos uma parte de tijolo e fui enchendo de concreto... As vigas foram feitas do mesmo jeito... A gente não tinha muitos recursos. Não tinha betoneira, nem vibrador, nem 'sarico' elétrico, nem bate estacas: o bate estaca era na mão. Ficavam dois homens em cima com um peso e dois em baixo. Aí, iam socando... Os arcos da fachada foram feitos com forma. $O$ alicerce da torre foi colocado na laje da pedra que tem no fundo do terreno. Essa laje sobe do rio e acaba ali. Para fazer o andaime, a gente ia no Mato com os companheiros. Lá a gente tirava a madeira e amarrava as peças com arame até em cima. $O$ acabamento da torre foi feito logo depois da construção dela. Depois, foi feita a estátua. Veio um espanhol de São Paulo. Ele tinha um rascunho da imagem. Eu ia chapando a massa e ele ia moldando. Quando eu terminei, ficou só o piso e o acabamento da calçada. O piso foi o João Tarcísio quem fez. Cada um colaborava como podia. Um dava um bezerro, outro dava um porco, outro dava uma galinha, outro dava uma dúzia de ovos... Era desse jeito. Tinha mês que a gente estava trabalhando e não tinha dinheiro para pagar o pessoal. Mas nós não deixávamos de trabalhar, não!". Completa D Ronalda Pontes de Resende:"Quem fez a imagem de São Miguel foi um

\footnotetext{
${ }^{143}$ Responsável pela construção da nova Igreja de São Miguel.
} 
estrangeiro. Não sei se ele era italiano ou espanhol... O nome dele era Virgílio... Virgílio Gasparô".

Segundo Sebastião Soares: "Todo mundo participou da construção dessa igreja. As pedras da parede foram tiradas para baixo do Manoelzinho Pereira Fazenda Cachoeira. O povo fez uma fila daqui até lá, e ia passando as pedras de mão em mão".

A inauguração da Igreja foi em 1962: "Carregamos pedras, mas valeu 0 esforço", declarou Pa. Panfílio Van den Bröeck, pároco do município na época.

Em 1987, uma grande movimentação pública marcou a morte da cidade de Nova Ponte. Cerca de 5 mil pessoas se reuniram na velha cidade e caminharam até a cidade nova ${ }^{144}$. Naquele momento, a entrada na cidade nova também foi muito marcante para a população. A multidão carregou uma cruz de madeira com aproximadamente três metros, e os representantes da CEMIG só puderam observar o movimento à distância. Um dos organizadores do movimento foi o Pe. Júnior, que relata:

"Reunimos pastores, padres de todas as igrejas, fizemos uma caminhada e entramos na cidade com uma grande cruz carregada pelo povo, 0 que emocionou muita gente. Aquele momento foi muito forte, pois era a vida de uma comunidade e nós celebramos ali, aos olhos da CEMIG que veio por representante de fora e ficou à distância do povo. Outro momento muito importante foi a saída da cidade velha. Eu me emociono! É bom ver o povo fortalecido, fazendo história. A história é algo que muda quando há força de participação e conscientização, independente de religião, classe social e tudo o mais. Tudo pode ser transformado. No começo dessa história o povo, na maioria muito simples, só pensava em si. Esse mesmo povo entendeu o processo, participou dele e passou a decidir em conjunto. A saída da velha cidade para a nova cidade emocionou a todos, pois de certa forma, a vida daquele povo estava enterrada ali".

\footnotetext{
${ }^{144}$ Local onde se encontrava a pedra fundamental de Nova Ponte. O lançamento da pedra fundamental foi em julho de 1987.
} 
A CEMIG tentou seguir os procedimentos convencionais adotados pelo setor elétrico no início das obras da usina, objetivando manter a configuração concreta dos impactos sócio-ambientais por ela causados, circunscritos à esfera dos direitos de propriedade. E na tentativa de esvaziar as iniciativas de natureza coletiva, a CEMIG restringiu a divulgação de informações oficiais sobre o projeto, que diziam respeito às questões cruciais para os segmentos sociais afetados: sobre as extensão e localização das terras inundadas, critérios de indenização, reconstrução de equipamentos e instalações públicas, e principalmente sobre o destino da cidade de Nova Ponte. A estatal também tentou adotar um tratamento individualizado no encaminhamento do processo despropriatório, com a negociação caso a caso do valor das indenizações a serem pagas aos atingidos. Diferentemente do que ocorreu em Nova Ponte, com a fundação da AMNP, na ausência de mecanismos de mediação para lidar com tais questões, o resultado desse tipo de processo será sempre a prevalência da lógica da empresa. Essa é, Segundo RIZEK (1996), a tentativa de deslocar o eixo da negociação para o terreno micro do interesse de cada um, onde a possibilidade da fala como recurso discursivo para a reivindicação é completamente anulada, quando são dados em contrapartida prêmios individuais, que reforçam a exclusão da fala.

A nova cidade de Nova Ponte foi inaugurada em novembro de 1992, e a definição de quais seriam os critérios para a transferência de sua população só foram conhecidos em fevereiro de 1990 com a assinatura do Termo de Acordo com os critérios de relocação da cidade de Nova Ponte, entre a CEMIG, a Prefeitura Municipal, a Câmara dos vereadores e a Associação de Moradores.

O processo de transferência adotado pela CEMIG teria ocorrido "por acaso", afirmam Pe. Júnior e Helder Naves Torres em consenso. O resultado imediato e prático alcançado foi em favor da manutenção dos interesses da própria CEMIG. Quanto à questão do rompimento dos laços afetivos da população com o "velho lugar", a opção em demolir as casas que iam sendo desocupadas na velha cidade o mais rápido possível, foi muito eficaz. E com o esvaziamento dos bairros, mais rápido a população resistente à mudança, se definia em sair. (Figura. 53). 
Foi acordado entre a CEMIG e a AMNP, que cada morador estaria livre para transportar da velha cidade para a nova, tudo o que desejasse aproveitar da casa ou edificação de sua propriedade. Mas depois de desocupada a propriedade ou o que restasse dela, seria demolida no dia seguinte. Os últimos moradores a deixar a cidade velha, já não reconheciam aquele lugar como a sua cidade, já não encontravam seus vizinhos. A cidade foi ficando a cada dia mais feia e vazia. Segundo Helder Naves Torres: "Aconteceu uma situação muito interessante, quando a pessoa se mudava para a cidade nova, a CEMIG destruía no outro dia a casa dela na velha cidade. Mesmo assim, teve gente que saiu de lá no dia do fechamento. Para as pessoas que iam ficando na cidade velha, ela ficava a cada dia mais feia, mais velha, parecia uma boca desdentada, porque quando uma casa era derrubada, ficava aquele vazio. E na cidade nova havia aquele crescimento pavoroso".

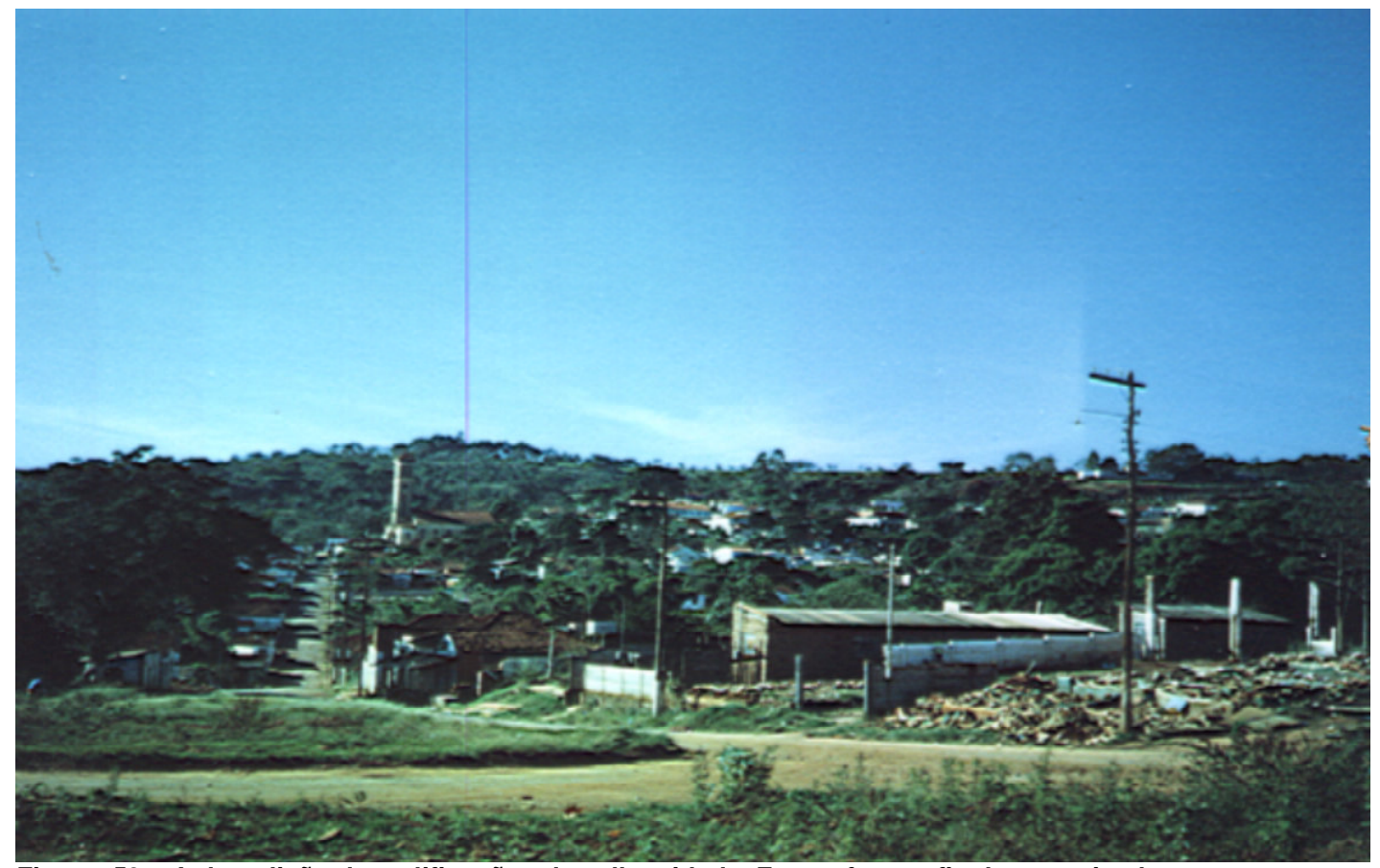

Figura. 53 - A demolição das edificações da velha cidade. Fonte: fotografia da pesquisadora.

$\mathrm{Na}$ inauguração da cidade nova, os discursos das autoridades políticas locais, regionais e da CEMIG, seguiram a lógica que a estatal sempre adotou quanto à divulgação, geração e controle de informações. A CEMIG procurou promover sua própria imagem, ao longo de todo o processo de projeção e construção da UHE e da nova cidade de Nova Ponte. A imagem foi construída 
em cima da idéia de que a estatal seria a grande benfeitora para a população de Nova Ponte e região. Relata Pe. Júnior: "A cidade foi inaugurada em novembro de 92. Eu fui para a inauguração. O presidente da CEMIG, na época era Carlos Eloy, me proibiu de falar. Eu tomei o microfone da mão dele e falei em nome da comunidade, disse tudo que tinha para dizer. A construção daquela cidade não era um mérito para o governo de Minas, mas o povo de Nova Ponte é que tinha o mérito. O que o governo tinha era a obrigação de fazer aquilo mesmo. O mérito era do povo que lutou para conseguir aquilo. $E$ mesmo assim, ninguém vai recuperar a vida deles, a cultura deles... não nada melhor que a própria história e isso ninguém vai dar ou recuperar para eles. Hoje, eu entendo claramente o que é uma história de um povo. Eu não mexeria nem em um quintal sem a autorização de todos os envolvidos".

A construção da cidade nova foi lenta e a cidade ficou conhecida como a "cidade das placas". As ruas foram abertas e placas foram afixadas por toda parte, nos lotes para que os futuros moradores os localizassem, e nos locais onde seriam erguidos os equipamentos coletivos, templos religiosos, etc.

Os moradores de Nova Ponte estavam sendo indenizados e havia muita gente com dinheiro para construírem aquilo que desejassem. Já quem ficava na velha cidade, estava se sentindo cada dia mais sozinho e inseguro. Segundo Helder Naves Torres: "Nós mudamos para cá em 4 de setembro de 93. Vieram vários netos para ajudar na mudança da minha avó. Minha tia até escreveu um 'trocinho' assim: 'Adeus minha cidade querida, nós te amamos!' Minha avó, que sempre foi muito cuidadosa disse: 'Vamos sair desse buraco logo, vamos embora!' Então, ela chegou aqui na casa, achou a casa uma maravilha, era ampla, esta casa era mais aberta que a outra de construção antiga. Ela já tinha problema de visão... catarata, coisas da idade. Aqui ela via as coisas com mais facilidade, podia enxergar tudo. Ela já estava achando aquilo tudo na cidade velha um buraco mesmo, com quase todas as casas do bairro antigo demolidas. A maioria dos moradores também se sentiu privilegiado, de uma certa forma tinham uma compensação, iam ter que sair mesmo... Mas depois a coisa foi caindo na real. $E$ aos poucos o dinheiro foi acabando... a gente ia se ajeitando... a cidade foi tomando fôlego... acho que hoje ainda está se adaptando!". 
A CEMIG adotou, para o cálculo do valor das indenizações a serem pagas aos moradores da área urbana de Nova Ponte, os preços do metro quadrado de área construída com base na tabela do SINDUSCOM - Sindicato da Indústria da Construção Civil - de Uberlândia. Os primeiros a serem indenizados foram os proprietários de terrenos. Na cidade velha, podiam ser encontrados enormes terrenos e pequenas chácaras, mesmo assim a CEMIG limitou a permuta em, no máximo, 2 terrenos na cidade nova, por propriedade na velha Nova Ponte. Relata Helder Naves Torres: "Eu levava o maior susto, as casas eram super valorizadas, não sei o que se passou! Acho que a pressão foi tão grande, que a indenização do metro quadrado foi do valor de Uberlândia... então rolou dinheiro. E todo morador teria o dinheiro se não fosse assentado. Quando a CEMIG decidiu que a indenização seria assim, algumas pessoas até construíram algumas casas boas para receberam mais de indenização. Já os terrenos, não. Os terrenos foram uma das primeiras coisas a serem acertadas. Todos os terrenos teriam o mesmo tamanho, de $360 \mathrm{~m}^{2}$, na cidade nova. Por exemplo, nossa casa tinha um terreno enorme e a CEMIG disse que não daria mais que dois terrenos. Daí o que aconteceu foi o próprio morador comprando terreno das pessoas mais pobres, oferecendo um dinheiro maior para ganhar mais terreno na cidade nova".

Na permuta das edificações particulares, ocorreram três situações: 1) a permuta total, quando a CEMIG se apropria de uma casa na cidade velha, implementa toda a construção de outra na cidade nova e a entrega ao proprietário. Aos poucos moradores que optaram em receber outra casa na nova cidade, o projeto arquitetônico desenvolvido pela equipe da CEMIG que Ihe foi entregue, seguia a lógica do mercado e o tamanho da casa na nova cidade, variava de acordo com o valor da indenização a receber: a planta mais simples era composta de sala, quarto, cozinha e banheiro, e a planta mais elaborada oferecia quatro quartos, sendo um suíte - a CEMIG não construiria nada, além disso. 2) A outra situação era a permuta do terreno e a indenização de construção. O proprietário ficava livre para construir na nova cidade da maneira que lhe agradasse. Nesse caso o pagamento das indenizações para a construção das casas na nova cidade, foi parcelado, sendo liberado paulatinamente, após cada medição de etapa da obra construída. Essa 
medição era executada por técnicos da CEMIG e na medida que se construía, se recebia pela construção. 3) A situação encontrada foi o pagamento da indenização total em dinheiro, sem a entrega do lote ao proprietário. Esperavase que esse proprietário fosse se fixar em outra cidade. Segundo Helder Naves Torres: "A CEMIG fez uma coisa muito interessante: dava o dinheiro, mas não dava tudo de uma vez. Ela ia na obra, olhava o que estava construído e até onde estava construído, só então, soltava mais um pouco de dinheiro. Acho que $90 \%$ da população ficou satisfeita com as casas. Quase todo mundo não tinha uma casa 'moderna'. Moderna que eu falo é ter uma sala, banheiro com privada, suíte, essas coisas. Na cidade velha, muitas pessoas adaptaram as casa, na fossa colocaram uma privada, ou dava uma reforma e estendia um banheiro, mas normalmente o banheiro estava fora de casa. As pessoas tinham uma perspectiva, acreditavam que a cidade nova ia crescer, ia evoluir. O dinheiro era muito circulado. Quando você constrói uma casa, você economiza muito e a CEMIG não estava preocupada com quanto se tinha gastado na obra, mas o quanto se tinha construído, por exemplo: se você subiu a parede, você vai receber mais, se você construiu o telhado, você vai receber mais ainda, mas se você gastou mais ou menos do que você recebeu não interessava, vinha a primeira parcela, a segunda... Mas foi bom... Porque quando as pessoas construíam... Quando você constrói sua casa, você constrói um elo ali. Meu pai dizia que só tinha visto algo assim em Brasília na época da construção, da alegria do crescimento.

A CEMIG não construiu muitas casas, os proprietários que optaram por essa situação, foram apenas os mais pobres, idosos e aqueles que não tinham como acompanhar a construção na nova cidade. Mas mesmo para esta opção, foi possível negociar com a CEMIG e fazer pequenas alterações nas plantas apresentadas pelo Departamento de Projetos e Edificações da CEMIG. O resultado foi uma cidade com características próprias. Nova Ponte não tem casas iguais, não tem conjuntos habitacionais e não tem casas populares idênticas, como é comum em outras cidades. Os proprietários receberam na permuta o dinheiro da avaliação da edificação ou a casa da CEMIG e alteravam ou não a planta baixa ou a fachada. A mesma situação ocorreu com os proprietários de comércio na velha cidade, quanto à permuta para a 
construção na cidade nova, a maioria construiu a sua maneira. Relata, Helder Naves Torres: "Em Nova Ponte, naquele momento, havia muita gente com dinheiro para construir aquilo que tinha vontade, o sonho da construção da casa nova, estava todo mundo alegre porque tinha dinheiro. E quando você tem dinheiro, você tem uma coisa nova, você tem aquela expectativa de coisa nova, de coisa boa, de coisa positiva. E a maioria das pessoas que tinham comércio continuou com seu comércio... até que o dinheiro foi acabando... e depois do 'BUM', tudo voltou ao normal e ficou um monte de gente desempregada. Mas não ficou aquela cidade toda igual, porque as pessoas construíram do seu jeito, foram poucos os que receberam a casa já construída pela CEMIG".

Os pagamentos justos das indenizações e a infra-estrutura de boa qualidade implementados na construção da cidade nova foram resultado da vitória da luta da população de Nova Ponte, que só foi alcançada através das associações fundadas durante o processo de construção da usina. Uma luta organizada pela própria sociedade novapontense. Segundo Pe. Júnior: "O que me deixou apreensivo foi quando houve a possibilidade de se trocar casa por casa na nova cidade ou indenização. A CEMIG indenizou a casa na velha cidade, sempre com o valor a mais, para que a população pudesse se encantar e vender rapidamente suas propriedades e depois construírem suas casas na cidade nova. Mas deixamos as pessoas livres para que pudessem escolher... com livre arbítrio. Mas a maioria, mais de $90 \%$ da população, construiu do seu jeito e a comunidade saiu ganhando com isso. Foi uma vitória muito importante, as indenizações foram boas e a infra-estrutura de toda a cidade construída é de primeira. Essa infra-estrutura da cidade poderia ter sido de terceira, mas nós - a AMNP - começamos a observar também a questão da qualidade do material que ia chegando para as construções na cidade nova".

A decisão de se inundar a velha cidade de Nova Ponte desconsiderou 0 alto custo social e os impactos que essa população veio a sofrer, as diretrizes da empresa a princípio, visavam apenas minimizar os custos e alcançar o maior desempenho possível para a UHE. 
A saída dessa população do seu "lugar", com abandono dos velhos hábitos cotidianos que compunham uma história que teve seu fim antecipado, uma morte anunciada, o que ilustra o contraponto entre temporalidades distintas. A história da cidade faz um paradoxo com a ponte, que lhe dá o nome. Desde o princípio, na formação da cidade, a ponte sugere o recomeço, sempre em reconstrução como experiência de sua própria provisoriedade.

Depois, com o fim, a CEMIG tenta impor uma nova imagem, de um novo começo - o "progresso" -, com uma nova identidade - o "moderno" (Figura. 54, 55 e 56). A exemplo do que ocorre com a implantação de projetos de grande porte como hidrelétricas, o caso de Nova Ponte registra um choque entre essas temporalidades diversas, sempre oscilando entre o tempo moderno e o que foi perdido, o que foi apagado ou o que a CEMIG pretendeu apagar.

A população como a velha cidade - uma cidade pequena onde o tempo passava devagar e a tradição rural se manifestava nos grandes lotes cheios de frutas, maritacas e crianças livres para brincar, em suas ruas e calçadas propícias aos encontros e "palestras", nos banquinhos e "salas de estar - se modificava lentamente com seu tempo próprio. Houve um longo período de indecisão e a população de Nova Ponte, aparentemente não se preocupou com o destino da cidade.

No momento que a população recebe a informação concreta de que todos os "seus lugares“ iriam desaparecer, esses espaços tornaram se lugares de valor e foram banhados de lembranças e significações. Documentar e preservar integralmente dois dos monumentos de Nova Ponte, o Chalezinho - o Arquivo Público - e a Fazenda Cachoeira - o Museu Rural -, foi a fórmula adotada para se tentar manter e preservar a memória do "lugar", levantando com isso, a questão do patrimônio enquanto forma de comunicação social, funcionando como símbolo e cumprindo funções diferenciadas na vida cultural dessa população. Um pequeno grupo de interessados moradores, começou a luta para a preservação desses monumentos, à revelia da população.

Posteriormente a população abraçou a causa e a adesão da AMNP e da prefeitura foi fundamental para o sucesso da empreitada. Hoje os monumentos 
são motivos de orgulho e apreciação dos moradores da cidade. Também foram abertos processos para o tombamento como patrimônio histórico da Casa da Fazenda Quebra Canoas ${ }^{145}$ e da Fazenda do Vauaçu ${ }^{146}$, bens imóveis de áreas rurais, escolhidos por suas qualidades construtivas e estéticas.

Mas apesar do esforço de seus moradores em criar "raízes" no novo "lugar", passados 13 anos de sua construção, Nova Ponte ainda é uma cidade pequena que ainda busca identificação, onde os encontros são raros e os vizinhos são outros, esta nova cidade se tornou grande demais para a manutenção dos relacionamentos quase familiares cultivados na velha cidade. De uma hora para outra as pessoas se modernizaram, se viram jogadas em uma cidade como a de Uberaba ou a de Uberlândia, declaram seus velhos moradores: "Nova Ponte velha, isso era muito marcante, as pessoas se encontravam mais, em determinados períodos, as pessoas vinham de fora, como na Semana Santa e na Cavalhada. Havia um ponto de encontro de toda a cidade, era o que todos chamavam de jardim, a pracinha lá em baixo, central. Todo mundo sabia quando alguém estava chegando. Quando a cidade mudou para cá, todo mundo perdeu referência, até hoje ainda se busca uma referência, um ponto de encontro, uma esquina na cidade" ${ }^{147}$.

Maria Aparecida Palmieri, declara: "O vizinho aqui nunca foi nosso vizinho, ele morava até longe da nossa casa, mas porque ele era da comissão e ele queria o lote dele na praça, hoje é meu vizinho... teve muita história assim... hoje os vizinhos são outros". Helder Naves Torres, completa: "A vizinha da minha avó, tanto a de baixo quanto a de cima, principalmente a de cima com quem se teve muitos anos de convivência, muito próxima mesmo, mudou para outro quarteirão. O que pretenderam fazer era uma aproximação, por exemplo: nós morávamos na praça e continuaríamos morando na praça na cidade nova. Mas o próprio desenho da cidade, com uma topografia totalmente diferente da velha, não teve condições de seguir a mesma estrutura da antiga cidade."

\footnotetext{
145 Processo no 893-T-73, aberto em 1973 no SPHAN.

146 Processo nำ1080-T-83, aberto em 1983 no SPHAN.

147 Depoimento de Helder Naves Torres, 2003.
} 
Os depoimentos mostram um enraizamento relacionado tanto ao território, e suas fronteiras entre os espaços públicos e privados, quanto às redes de sociabilidade. Estas redes de sociabilidade que tinham lugar na velha cidade estavam enraizadas na constituição daquela comunidade, e as relações entre o espaço público e o privado foram definidas em função de uma história coletiva de ocupação urbana. Ao ser reassentada para o "novo lugar" a população não conseguiu manter as mesmas relações de vizinhança, como aconteciam no antigo espaço de convivência ${ }^{148}$, demonstrando que o processo de urbanização não deve ser desvinculado da vida que dá o sentido ao espaço cotidiano.

O espaço urbano e o ambiente construído não constituem meros cenários para a sociedade; é necessário procurar problematizar a questão do espaço, sua apropriação, seu uso e sua representação. Para o planejamento urbano alcançar seu objetivo de vitalidade urbana, seria necessário estimular e catalisar o maior espectro e a maior quantidade possível de diversidade em meio aos usos e às pessoas; deveria propiciar uma interpenetração contínua nas vizinhanças; deveria ajudar a promover a identificação das pessoas com o lugar; deveria explicitar a ordem visual das cidades, por meio da promoção e da compreensão de ordem funcional. Os responsáveis deveriam ter um conhecimento detalhado sobre os lugares específicos e únicos da cidade precisariam conhecer a fundo os seus lugares específicos ${ }^{149}$. Essas recomendações de JACOBS (2000) poderiam se aproximar das reivindicações dos moradores da velha cidade. Entretanto, apesar de seus esforços, a nova cidade ainda guarda as marcas do que se interrompeu, das perdas e lacunas que se inscrevem nas transformações do território urbano, de seus usos, de seus vínculos com a forma de realização das relações sociais.

\footnotetext{
${ }^{148}$ Segundo BOSI (1995), as relações de vizinhança e o espaço de convivência favorecem o enraizamento, ao compartilharem um processo de transferência como ocorreu em Nova Ponte, o processo de ocupação do "novo lugar" deveria acontecer ao mesmo tempo de sua construção identitária.

149 JACOBS (2000).
} 


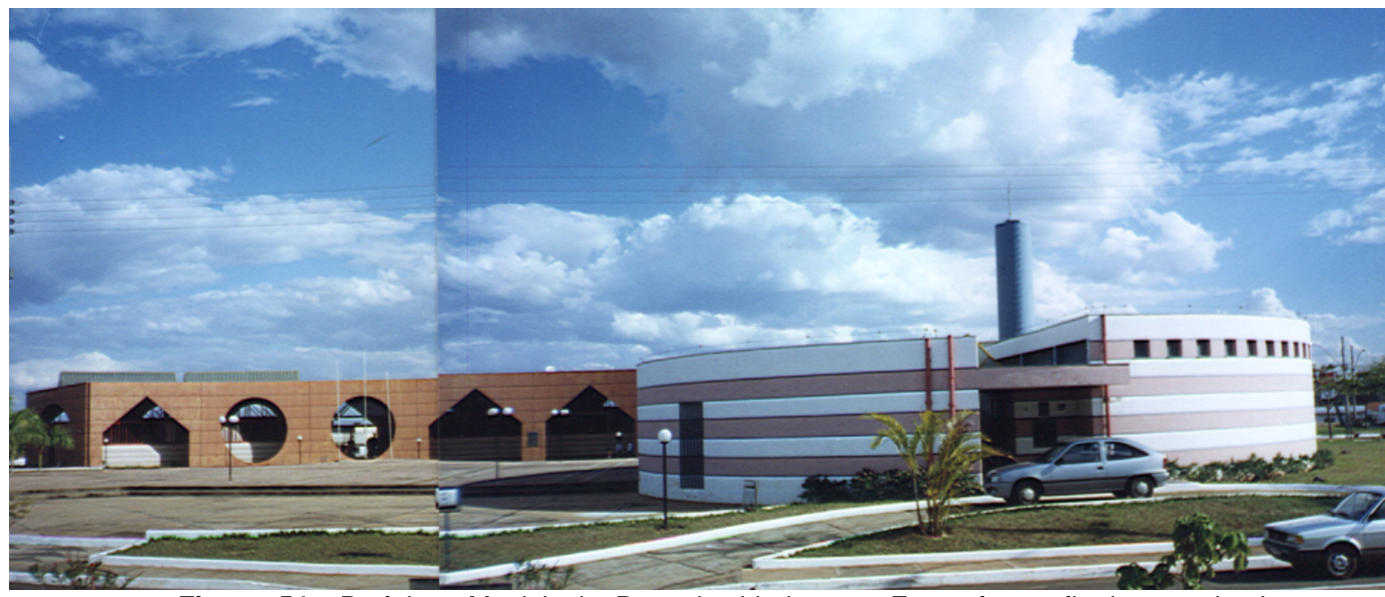

Figura. 54 - Prefeitura Municipal e Paço da cidade nova. Fonte: fotografia da pesquisadora.

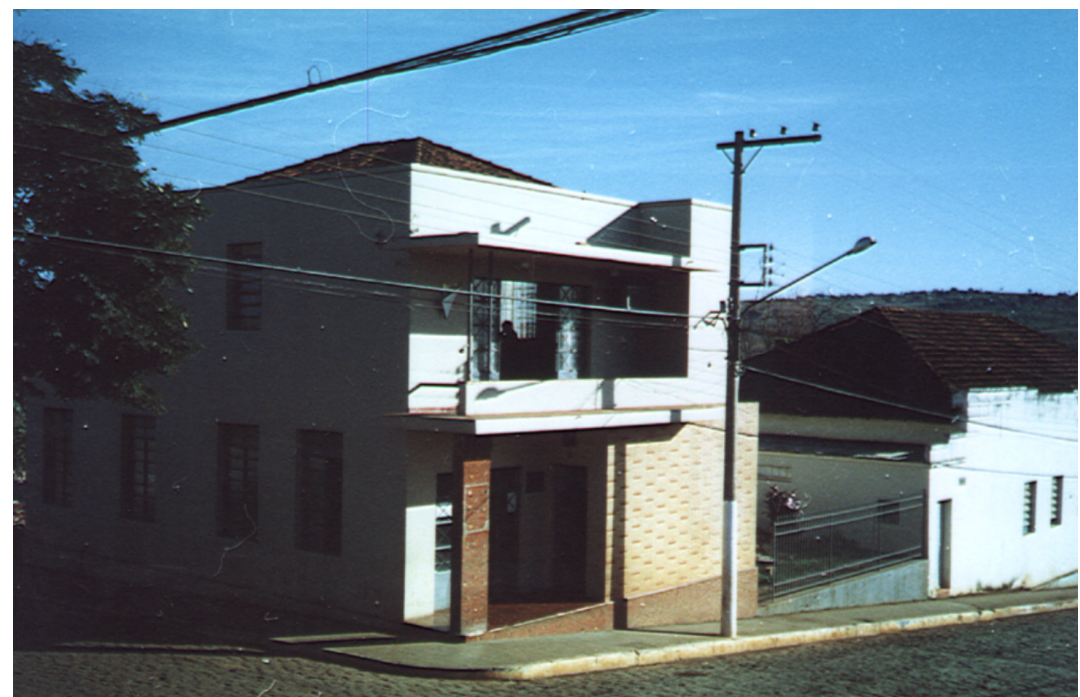

Figura. 55 - Prefeitura Municipal da velha cidade até 1993. Fonte: fotografia da pesquisadora.

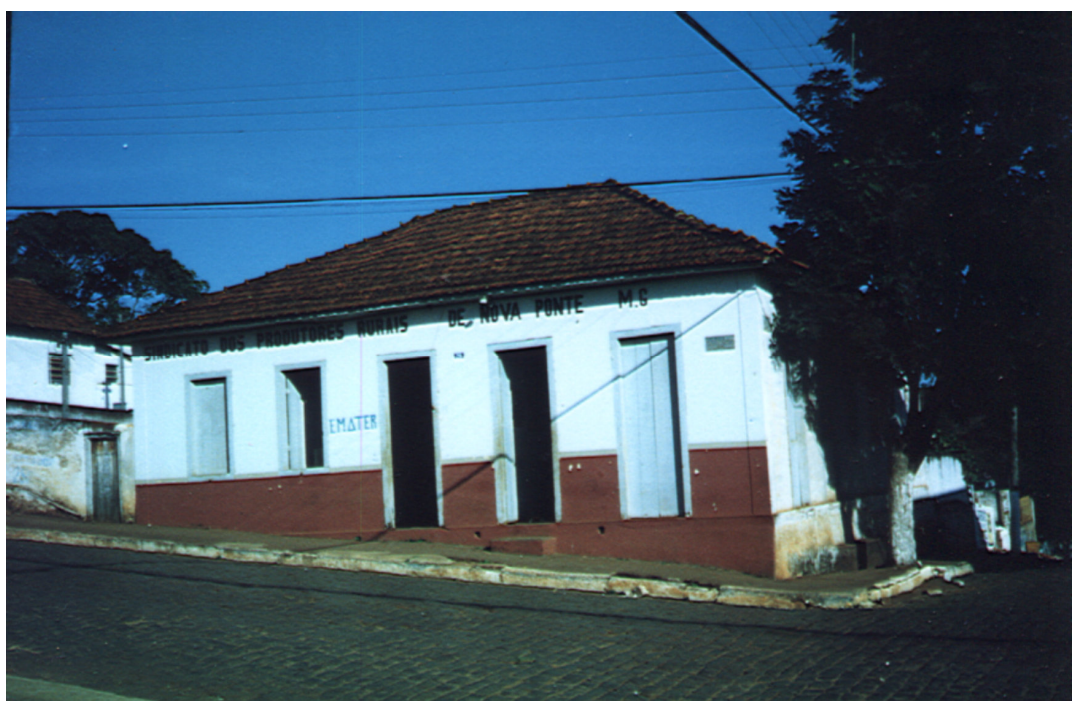

Figura. 56 -Prefeitura de Nova Ponte de 1939 a 1943. Em 1993 era o Sindicato dos produtores rurais da cidade. Fonte: fotografia da pesquisadora. 


\section{Conclusões}

Apesar da crescente importância das questões sócio-ambientais e a intensidade dos impactos causados pela construção de usinas hidrelétricas, até meados dos anos setenta, a conduta estratégica adotada pelas concessionárias evitava qualquer envolvimento ou compromisso com iniciativas que fossem além do ressarcimento financeiro aos prejuízos passíveis de indenização e da remoção da população residente na área a ser inundada pelas águas da barragem.

Em Nova Ponte ganharam ainda visibilidade os processos que ocorreram no Brasil a partir de 1978, quando grupos populares alcançam visibilidade e irromperam na cena pública reivindicando seus direitos, a começar pelo direito de reivindicar direitos. Novos atores começavam a ocupar os espaços públicos e os movimentos sociais passavam a serem vistos por "suas linguagens, pelos lugares onde se manifestavam, como indicadores da emergência de nova identidades coletivas" ${ }^{150}$. A novidade da década de oitenta foi a afirmação de um novo sujeito - o coletivo - em novos lugares políticos - a experiência do cotidiano - e uma prática nova - a criação de direitos a partir da consciência de interesses e vontades próprias ${ }^{151}$, conseqüência da desconfiança dos sujeitos com relação às instituições políticas e os sistemas de mediação, novas relações com os espaços públicos.

Neste novo cenário as mudanças na conduta estratégica das empresas energéticas vão se acelerar. A primeira transformação acontece no campo institucional com a definição de uma legislação ambiental, que entre outras inovações passa a destacar a exigência do prévio licenciamento ambiental para a implantação das usinas. A segunda mudança aconteceu com o avanço do processo de democratização da sociedade brasileira, que propiciou um canal de ressonância e alguma vigilância na aplicação dos dispositivos regulatórios instituídos. Os avanços institucionais somente iriam adquirir alguma efetividade

\footnotetext{
${ }^{150}$ SADER (1995).

${ }^{151}$ CHAUI, prefácio no texto de SADER.
} 
operacional em meados dos anos oitenta, através de uma série de resoluções editadas em 1986 pela Comissão Nacional do Meio Ambiente - CONAMA, regulamentando os dispositivos e instrumentos jurídicos (ELETROBRAS, 1991).

A crescente sensibilidade da sociedade brasileira, a pressão de organismos financiadores externos, como o BIRD, e as mobilizações dos segmentos populacionais atingidos pela construção de barragens no tocante às decisões relativas à desocupação das áreas inundáveis, provocaram alterações gradativas na postura das concessionárias do setor.

A criação da Comissão Regional dos Atingidos por barragens - CRAB, no sul do país, é um marco na transição para uma nova forma de tratamento das questões referentes ao pagamento de indenizações e remanejamento dos atingidos, e vem solidificar a organização popular em torno da defesa de seus interesses nos processos decisórios do setor, levando as empresas a se iniciarem na busca de soluções negociadas para a viabilização de seus empreendimentos.

Os estudos para a construção da UHE Nova Ponte tiveram início na década de trinta, época da emancipação do município. E o destino da cidade de Nova Ponte já se tornava conhecido. A cidade teve toda sua área urbana inundada pelas águas da barragem na construção da usina hidrelétrica. $\mathrm{E} O$ processo que se seguiu, alterou os rumos das políticas e práticas de planejamento através de uma inovadora experiência participativa: a luta dos "afogados" para a construção de uma nova cidade no "padrão moderno".

A atuação compartilhada nos projetos urbanos, a constituição e 0 reconhecimento de novos agentes - destaque para a AMNP, na negociação com a CEMIG, legitimou novos espaços, o que garantiu o direito à cidade e aos bens coletivos urbanos. Esta participação alcançou uma dimensão expressiva no sentido da socialização das decisões coletivas, na tentativa de construção e/ou recuperação de sua identidade, na recuperação de sua história e na definição de valores, conseguindo produzir um grande impacto sobre o poder político regional e estadual. 
O processo de mudança e a possibilidade da transferência da população incidiram sobre os modos de ocupação e apropriação do espaço, sobre os valores e representações vinculados ao local. Com o início das obras da construção da barragem, a cidade sofreu uma estagnação e um grande retrocesso em sua perspectiva de desenvolvimento. O êxodo urbano e rural e o impacto sócio-econômico direto retrataram uma época de incertezas para a população da velha cidade. Na década de sessenta, o quadro que se configurava era de total ausência de futuro com a morte já anunciada da cidade. Não havia a perspectiva de construção de uma cidade para abrigar a população desapropriada. Na década de setenta, há o agravamento deste quadro, com o início efetivo das obras da usina e a construção da vila operária.

Sob a ótica da CEMIG, a princípio, não haveria porque alterar a postura convencional de buscar a liberação da área para a construção da usina, que consistia na desapropriação mediante o pagamento de indenizações, sendo concedido aos habitantes um determinado prazo para uma migração individualmente programada, ao menor custo para a empresa e em prazo compatível ao cronograma da obra. Para alcançar seus objetivos a empresa buscou bloquear qualquer discussão mais abrangente referente à construção da usina na região, evitou ao máximo a interlocução com as Prefeituras e as Câmaras de Vereadores dos municípios atingidos, na tentativa de esvaziar as iniciativas de natureza coletiva contrárias ao empreendimento e restringiu a divulgação de informações oficiais sobre o projeto. A CEMIG procurou adotar um tratamento individualizado na negociação das desapropriações, tentando uma negociação caso a caso sobre o valor das indenizações a serem pagas aos atingidos.

Este contexto, de informações parciais e conflitantes sobre questões cruciais para os segmentos sociais atingidos - a extensão e localização das terras inundadas, critérios de indenização e o destino da própria cidade de Nova Ponte, possibilitou a aglutinação de prefeitos e fez surgirem lideranças locais - com destaque para o Pe. Júnior e a AMNP, para negociar alternativas para a população da área. Foi através de práticas reivindicatórias que a população de Nova Ponte, com uma atuação sistemática e coordenada, conseguiu construir canais de negociação para manter o diálogo com a 
CEMIG. Além de buscar o respaldo na opinião pública para suas reivindicações e a manutenção das informações sobre o processo e as negociações com a concessionária.

A negociação entre a empresa e os atingidos tradicionalmente respeita os direitos de propriedade, o que estabelece apenas o ressarcimento financeiro aos atingidos passíveis de indenização. Aos atingidos restou buscar na mobilização e na pressão política a defesa de quaisquer outros interesses, individuais ou coletivos, não dedutíveis dos danos patrimoniais, o que incluía a discussão em torno da construção ou não da nova cidade.

A Igreja Católica constituiu o ponto de ancoramento dos atingidos na produção de um movimento popular que teve início com o "Movimento SOS Nova Ponte", e buscou respaldo na mídia para legitimar as reivindicações e potencializar o movimento como acontecimento significativo. Foi através de teias de solidariedade que os atingidos se agregaram em torno dos problemas comuns para lutar pelo reconhecimento do direito da população novapontense à sua cidade.

O direito à cidade pressupõe esta reflexão integral sobre sue território e de suas relações sociais e as questões que foram geradas neste trabalho, da propriedade da terra aos problemas de segregação, mostram que a construção da usina interferiu diretamente tanto nesse mesmo território quanto nas relações sócio econômicas e sócio políticas. $O$ trabalho trata de reconstruir as experiências dessa população, durante a construção da UHE e a relocação da cidade de Nova Ponte, que estão inseridas em um formato particular do processo de mudança social e de reconfiguração territorial.

A cidade de Nova Ponte foi a primeira no estado de Minas Gerais e uma das primeiras no país a se firmar como um marco no tratamento da concessionária com os atingidos na construção de barragens. A atuação dos sujeitos sociais constituídos e organizados foi capaz de garantir seus direitos e conquistas frente à estatal, em um campo de conflitos que envolveram uma diversidade de agentes, enquanto prática democrática que aconteceu em um 
momento determinado, abrindo a história passada diante dos riscos de desaparecimento de seu suporte e ancoramento territorial. ${ }^{152}$

A participação da população se estendeu sobre o projeto urbanístico da nova cidade, fazendo com que "as coisas voltassem para os lugares originais". O que prevaleceu foi a vontade da população em manter a mesma localização dos bairros da velha cidade. Tentaram seguir na cidade planejada a lógica da velha cidade, tentaram manter os moradores com a mesma vizinhança da velha cidade. Com o avanço nas negociações, a maioria da população da antiga cidade optou por permanecer na nova cidade. A liberdade na escolha dos projetos arquitetônicos para as novas edificações resultou em uma cidade com características próprias, onde não são encontradas casas iguais: cada um construiu a sua maneira.

No entanto, mesmo passados 13 anos da construção da nova cidade e do remanejamento de sua população, Nova Ponte ainda é a "cidade nova" para seus moradores que buscam no "moderno" uma nova identidade, resultado de um processo imposto "de cima para baixo" justificado por um "progresso" que induziu a um novo começo ou a uma retomada e a uma redefinição das velhas práticas enraizadas na antiga cidade.

A CEMIG procurou legitimar a idéia de "progresso" para a região e para o país com a construção da usina hidrelétrica. E seguindo a lógica tradicional, a empresa procurou promover sua própria imagem como benfeitora da população de Nova Ponte, trazendo o desenvolvimento para a região através da usina, ao construir a cidade nova e ao permitir a participação da população atingida no processo. A noção de progresso pressupõe "um desdobramento temporal de algo que já existira desde o início como germe ou larva, de tal modo que a história não é a transformação ou criação, mas a explicitação de algo apenas idêntico que vai apenas crescendo com o correr do tempo" (CHAUÍ, 1989). A noção de desenvolvimento pressupõe "um ponto fixo,

\footnotetext{
152 O registro político desses sujeitos sociais localiza-se na própria reivindicação dos direitos, LEFORT sugere que a democracia é infindável, porque o conflito também o é. A democracia assim concebida é a reinvenção da política. Desde a legitimação das reivindicações à conquista dos direitos e a sua permanente reformulação, o que sobressai é a construção de uma história que continua aberta (SILVA, 1996).
} 
idêntico e perfeito, que é o ponto terminal de alguma realidade e ao qual ela deverá chegar normativamente" (idem, 1989). Os dois conceitos excluem da história o inédito, e a "história de uma sociedade passa a ser regida por algo que ela deve realizar a qualquer preço. Passa-se da história ao destino" (idem, 1989).

A história narrada, a memória, o patrimônio e o passado formaram um espaço múltiplo e a opção em trabalhar com narrativas se apoiou na possibilidade de recriar a memória dos que perderam e daquilo que se perdeu (BENJAMIN, 1994).

Cada narrador ao reconstruir suas histórias estabelece uma relação com a temporalidade, o que remete a uma concepção do tempo. Numa concepção cronológica, o tempo histórico é percebido numa relação de exterioridade aos acontecimentos. O caráter da temporalidade que surge ao longo do texto é marcado por oscilações. $\mathrm{E}$ as narrativas que foram agregadas ao texto, seguem em uma reflexão sobre o cotidiano e as transformações que forçosamente ocorreram, considerando os vínculos do narrador com a cidade. As narrativas demonstram as formas e os usos cotidianos ligados a uma vida ancorada no lugar. Os "narradores" e moradores da velha cidade de Nova Ponte, diante do quadro da morte anunciada da própria cidade expressaram um sentimento de perda e criaram a imagem da tradição, de um paraíso, com uma visão nostálgica e romântica da cidade quase ideal, o que não refletiu em nenhum momento a recusa à modernidade, ao contrário, reivindicaram para a construção da nova cidade o "padrão moderno", o que expressou a intenção e adesão dos mesmos a respeito do desenvolvimento e do convívio das pessoas no novo lugar.

Para Benjamin, a verdadeira narração está ligada a uma tradição viva e coletiva, característica de comunidades como a de Nova Ponte, na qual os indivíduos não se encontram separados pela divisão do trabalho, mas onde sua organização coletiva reforça a vinculação consciente a um passado comum, permanentemente vivo nos relatos dos narradores ${ }^{153}$. A idéia deste estudo retoma Benjamin ao procurar escrever uma outra história, apoderando-se de ${ }^{153}$ GAGNEBIN (1982). 
lembranças na forma que cintilaram no instante do perigo na busca de "reter uma imagem do passado na forma como ela se configurou repentinamente para o sujeito histórico no momento do perigo. O perigo ameaça tanto o conteúdo dado da tradição quanto aqueles que a recebem" ${ }^{154}$.

No estudo do caso de Nova Ponte, a pesquisa procurou identificar e registrar: o que se "afogou" e o que se pretendeu apagar; o que gerou luta para ser preservado e reconstruído na nova cidade. Partindo desse jogo de forças, com o reassentamento da população neste novo espaço, o que se configura é a construção de uma história singular. Uma história que continua aberta e sujeita a indeterminações, mesmo que se constate que uma ordem de interesses, desigualdades e novas distâncias tenham se desenhado à luz de uma modernização que forçosamente, os moradores da nova cidade tiveram que experimentar.

${ }^{154}$ BENJAMIN, W. In: GAGNEBIN, 1982. 


\section{Referências Bibliográficas}

ACSELRAD, H. Políticas ambientais e construção democrática. In: GILNEY VIANA, M.S.; DINIZ, N. (Org.). 0 desafio da sustentabilidade: um debate sócio-ambiental no Brasil. São Paulo: Fundação Perseu Abramo, 2001. p. 79-90.

ANDRADE, C.R.M. A construção historiográfica da cidade e do urbanismo moderno no Brasil: o caso das cidades novas planejadas. In: PINHEIRO, E.P.; GOMES, M.A.A.F. (Org.). A cidade como história: os arquitetos e a historiografia da cidade e do urbanismo. Salvador: EDUFBA, 2005.

ARENDT, H. A condição humana. São Paulo: EDUSP, 1981.

BARRAZA, X. Por uma subjetivação da sociedade. In: MOISÉS, J.A. et al. Alternativas populares da democracia: Brasil, anos 80. Petrópolis: Vozes, 1982. (Coleção de estudos latinos-americanos "nuestra-america"). p.121125.

BAVA, S.A.C. Práticas cotidianas e movimentos sociais: elementos para reconstituição de um objeto de estudo. 1983. 217p. Dissertação (Mestrado) - Faculdade de Filosofia, Letras e Ciências Humanas, Universidade de São Paulo, São Paulo, 1983.

BENJAMIM, W. Magia e técnica, arte e política: ensaio sobre literatura e história da cultura. Tradução de Sérgio Paulo Rouanet. 3.ed. São Paulo: Brasiliense, 1987. (Obras escolhidas, 1).

BOSI, A. Memória e sociedade. São Paulo: Companhia das Letras, 1995.

BRANDÃO, C.A.L.; PENNA, A.D. Memória histórica de Nova Ponte. Belo Horizonte: CEMIG, 1997.

BRESCIANI, M.S. Cidades: espaço e memória. In: O DIREITO à memória: patrimônio histórico e cidadania. São Paulo: Departamento do Patrimônio Histórico, 1992. p.161-168.

Metrópolis: as faces do monstro urbano. Revista Brasileira de História, São Paulo, n.8/9, p.35-68. 1985.

BURSZTYN, M. Políticas públicas para o desenvolvimento. In: A DIFíCIL sustentabilidade: política energética e conflitos ambientais. Rio de Janeiro: Garamond, 2001. 
CÂMARA MUNICIPAL DE NOVA PONTE. Lei orgânica do município de Nova Ponte: 12 de novembro, 1990. Nova Ponte.

CARNEIRO, R. Estado, mercado e o desenvolvimento do setor elétrico brasileiro. 2000. 400p. Tese (Doutorado) - Universidade Federal de Minas Gerais, Belo Horizonte, 2000.

CENTRAIS ELÉTRICAS DE MINAS GERAIS. Projeto memória histórica de Nova Ponte. Belo Horizonte: CEMIG-LEME-UFMG; Arquivo Público de Nova Ponte, 1995.

CENTRAIS ELÉTRICAS DE MINAS GERAIS. Departamento de Projetos de Edificações. Relatório de viagem à Nova Ponte, sub-projeto recolocação urbana. Belo Horizonte, 1987. (Relatório Informativo da DPC, referente ao período de 1992 - 1994. Cidade de Nova Ponte, Urbanização Integral a Serviço da Comunidade. Belo Horizonte: 2 de maio de 1994).

CHOAY, F. A alegoria do patrimônio. São Paulo: UNESP, 2001.

CIUCCI, G. et al. La ciudad americana. Barcelona: Gustavo Gili, 1975.

CORREIA, T.B. A casa: do abrigo à máquina de morar. Estudos e Debates, Brasília, n.38, dez. 1999.

DAGNINO, E. Sociedade civil e espaços públicos no Brasil. São Paulo: Paz e Terra, 2002.

DRAIBE, S.M. Rumos e metamorfoses/estado e industrialização no Brasil: 1930-1960. Rio de Janeiro: Paz e Terra, 1985.

ELETROBRAS - Centrais Elétricas Brasileiras. Panorama do setor de energia elétrica no Brasil. Rio de Janeiro: ELETROBRAS/Centro de Memória da Eletricidade, 1988.

EVERS, T. De costas para o estado, longe do parlamento. Novos Estudos CEBRAP, São Paulo, v.2, n.1, 1983.

Identidade: a face oculta dos movimentos sociais. Novos Estudos CEBRAP, São Paulo, v.2, n.4, 1984.

FARIA, J.S. Monografia de Nova Ponte. Nova Ponte: Diretório Municipal de Geografia, 1939.

FERRARA, L.D. Os significados urbanos. São Paulo: EDUSP; FAPESP, 2000.

FONSECA, M.C.L. O patrimônio em processo: trajetória da política federal de preservação no Brasil. Rio de Janeiro: UFRJ; IPHAN, 1997. 
FROELICH, G.M. Ilha Solteira: uma história de riqueza e poder. São Paulo: EDUC; FAPESP, 2001.

FROTA, I. O setor elétrico e seus conflitos: os novos e os velhos desafios. In: A DIFÍCIL sustentabilidade: política energética e conflitos ambientais. Rio de Janeiro: Garamond, 2001. p.156.

GAGNEBIN, J.M. História e narração em Walter Benjamin. São Paulo: Perspectiva; UNICAMP; FAPESP, 1994.

1982.

Walter Benjamin: os cacos da história. São Paulo: Brasiliense,

GRUPO DE TRABALHO INTERMINISTERIAL - atingidos por barragens. Memória das reuniões realizadas: anexos e relatório final. Brasília: República Federativa do Brasil/Presidência da República/Casa Civil/Câmara de Política Social, 2004.

HABERMAS, J. Mudança estrutural da esfera pública. Rio de Janeiro: Tempo Brasileiro, 1984.

HELLER, A. O cotidiano e a história. São Paulo: Paz e Terra, 2000.

HOBSBAWM, E.J. Nações e nacionalismo desde 1780: programa, mito e realidade. Rio de Janeiro: Paz e Terra, 1990.

HOWARD, E. Ciudades - jardim del mañana. In: AYMONINO, C. Origens y desarrollo de la ciudad moderna. Barcelona: G.Gili, 1972.

JACOBS, J. Morte e vida de grandes cidades. São Paulo: Martins Fontes, 2000.

KOPP, A. Quando o moderno não era um estilo e sim uma causa. São Paulo: Nobel; EDUSP, 1990.

KOWARICK, L. As lutas urbanas e os movimentos populares. In:

Escritos urbanos. São Paulo: Ed.34, 2000.

KOWARICK, L.; BONDUKI, N. Espaço urbano e espaço político: do populismo à redemocratização. In: KOWARICK, L. (Org.). As lutas sociais e a cidade, São Paulo: passado e presente. Rio de Janeiro: Paz e Terra, 1988. p.133-167.

LEFEBVRE, H. O direito à cidade. São Paulo: Moraes, 1991.

LEFORT, C. A invenção democrática: os limites do totalitarismo. São Paulo: Brasiliense, 1987.

LEME Engenharia: Memória Técnica da Usina Hidrelétrica de Nova Ponte. Belo Horizonte: s.d. (Capítulo 3); Memória Técnica da Usina Hidrelétrica de 
Nova Ponte. Belo Horizonte: s.d. (Capítulo 4); Monitoramento SócioAmbiental Urbano da cidade de Nova Ponte. Belo Horizonte: novembro de 1993. (Capítulo 3).

LIMA JÚNIOR, A. A capitania das Minas Gerais. Belo Horizonte: Itatiaia, 1978.

LIMA, L.G.S. Notas sobre as comunidades eclesiásticas de base e a organização política. In: MOISÉS, J.A. et al. Alternativas populares da democracia: Brasil, anos 80. Petrópolis: Vozes, 1982. (Coleção de estudos latino-americanos "nuestra-america"). p.41-72.

LITTLE, P. Os conflitos socioambientais: um campo de estudo e ação política. In: A DIFÍCIL sustentabilidade: política energética e conflitos ambientais. Rio de Janeiro: Garamond, 2001.

LYNCH, K. A imagem da cidade. São Paulo: Martins Fontes, 1988.

MOVIMENTO DOS ATINGIDOS POR BARRAGENS. Dossiê: ditadura contra as populações atingidas por barragens aumenta a pobreza do povo brasileiro. Secretaria Nacional. Disponível em:<http://www.riosvivos.org.br/arquivos/5711796.14.doc>. Acesso em: 05/12/2004.

MAIRA, L. Origens e conteúdos do cristianismo popular. In: MOISÉS, J.A. et al. Alternativas populares da democracia: Brasil, anos 80. Petrópolis: Vozes, 1982. p. 127-139.

MANGE, E.R.C. Planejamento em Urubupungá. 1963. 74p. Tese (Livre Docência) - Escola Politécnica, Universidade de São Paulo, São Paulo, 1963.

MARICATO, E. Habitação e cidade. São Paulo: Atual, 1997.

McADAM, Doug. The political process and development of black insurgency. Chicago: University of Chicago Press, 1982. In: In: Navarro, Zander org: Política protesto e cidadania no campo: As lutas sociais dos colonos e dos trabalhadores rurais no Rio Grande do Sul. Porto Alegre: Editora de Universidade / UFRGS, 1996.

MORAES, Maria S. No rastro das águas: organização, liderança e representatividade dos atingidos por barragens. In: Navarro, Zander. Política, protesto e cidadania no campo: As lutas sociais dos colonos e trabalhadores rurais no Rio Grande do Sul. Porto Alegre: Editora de Universidade / UFRGS, 1996.

NEDER, R.T. Crise socioambiental: estado e sociedade civil no Brasil (1982-1998). São Paulo: Annablume; FAPESP, 2002. 
OLIVEIRA, F. A economia da dependência imperfeita. Rio de Janeiro: Graal, 1989.

PAOLI, M.C. Memória, história e cidadania: o direito ao passado. In: O DIREITO à memória: patrimônio histórico e cidadania. São Paulo: Departamento do Patrimônio Histórico, 1992. p.25-28.

PEREIRA, M.L.D.L. Negociações e parcerias: a gestão urbana democrática participativa. 1999. 200p. Tese (Doutorado) - Faculdade de Filosofia, Letras e ciências Humanas, Universidade de São Paulo, São Paulo, 1999.

PEROTE, L.T.R. O urbanismo de Nova Jaguaribara In: Caderno de Resumos do X Encontro Nacional da ANPUR. Belo Horizonte, 2003.

POVOS indígenas no Brasil. São Paulo: CEDI, 1991. p.80.

PIQUET, R. Cidade - empresa: presença na paisagem urbana brasileira. Rio de Janeiro: Jorge Zahar, 1998.

POL, E. História da psicologia ambiental en Europa: análise sócio histórica. Barcelona: Antropos, 1988.

PONTES, H.A. Memória eclesiástica da diocese de Uberaba. In: A IGREJA de Uberaba - história até 1937. Uberaba: [s.n], 1987.

PREFEITURA MUNICIPAL DE NOVA PONTE. Resolução - aprovação do plano diretor de relocação e reconstrução da nova cidade e outras providências: termo de acordo. Belo Horizonte, 1990.

REBOUÇAS, L.M. O planejado e o vivido: o reassentamento de famílias ribeirinhas no Pontal do Paranapanema. São Paulo: Annablume; FAPESP, 2000.

REIS, N.G. Espaço e memória: conceitos e critérios de intervenção. In: O DIREITO à memória: patrimônio histórico e cidadania. São Paulo: Departamento do Patrimônio Histórico, 1991.

GAGNEBIN, J.M. ulo: FAU/USP, 1994. (Cadernos de pesquisa do LAP, 1).

- Notas sobre o urbanismo no Brasil - segunda parte: séculos

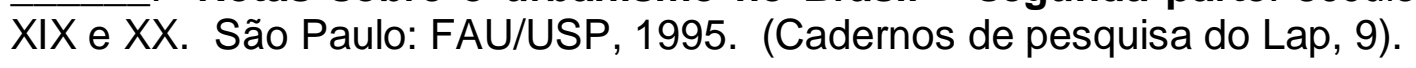

SADER, E. Quando novos personagens entram em cena: experiências, falas e lutas dos trabalhadores da Grande São Paulo, 1970-80. Rio de Janeiro: Paz e Terra, 1988.

SERTÃO da Farinha Podre actual Triângulo Mineiro. Arquivo Público Mineiro, Belo Horizonte, ano 19, 1909. 
SIMMEL, G. El individuo y la libertad: ensayos de crítica de la cultura. Barcelona: Ediciones Península, 1986.

REVISTA: “Estradas primevas no Sertão da Farinha Podre”. Arquivo Público de Uberaba: Ano VI 1901.

RIBEIRO, G.L. Empresas transnacionais: um grande projeto por dentro. São Paulo: APOCS; Marco Zero, 1991.

RIZEK, C.S.; MELLO E SILVA, L. Trabalho e qualificação no complexo químico paulista. [S.I.:S.n.], 1996. Relatório de Projeto.

ROLNIK, R. Planejamento urbano nos anos 90: novas perspectivas para velhos temas. In: Silva, K.P. (Org.). A cidade contemporânea: tendências e conceitos. Bauru: UNESP, 1995.

ROTHMAN, Franklin D. A emergência do movimento dos atingidos de bacia do rio Uruguai 1979 - 1983. In: Navarro, Zander org: Política protesto e cidadania no campo: As lutas sociais dos colonos e dos trabalhadores rurais no Rio Grande do Sul. Porto Alegre: Editora de Universidade / UFRGS, 1996.

SACHS, I. Ecodesenvolvimento: crescer sem destruir. São Paulo: Vértice, 1986.

SANTOS, C.N.F. Movimentos urbanos no Rio de Janeiro. Rio de Janeiro: Zahar, 1981.

(Coord.). Quando a rua vira casa: a apropriação de espaços de uso coletivo em um centro de bairro. 3.ed. São Paulo: IBAM/FINEP; Projeto, 1985.

SANTOS, M. Técnica, espaço, tempo: globalização e meio técnicocientífico informacional. São Paulo: Hucitec, 1994.

SANTOS, T.C.C.; CÂMARA, J.B.D. (Org.). GEO Brasil 2002 - perspectivas do meio ambiente no Brasil. Brasília: Edições IBAMA, 2002.

SEGAWA, H. De Brasília a Ita. In: ARQUITETURAS no Brasil dos anos 80. São Paulo: Projeto, 1988. p.47-48.

SEVCENKO, N. A literatura como missão: tensões sociais e criação cultural na primeira república. São Paulo: Brasiliense, 1989.

SIGAUD, L. Efeitos sociais de grandes projetos hidrelétricos: as barragens de Sobradinho e Machadinho. Rio de Janeiro: Programa de PósGraduação em Antropologia Social; Museu Nacional; UFRJ, 1986. (Comunicação, 9). 
SILVA, O.B. Memória, preservação e tradições populares. In: O DIREITO à memória: patrimônio histórico e cidadania. São Paulo: Departamento do Patrimônio Histórico, 1991.

SILVA, S.S. Política de meio ambiente no Brasil no início dos anos 90: construção da cidadania ambiental. 1996. 167p. Dissertação (Mestrado) Faculdade de Filosofia, Letras e Ciências Humanas, Universidade de São Paulo, São Paulo, 1996.

SOUZA, H.J. Município de Boa Esperança: participação popular e poder local. In: MOISÉS, J.A. et al. Alternativas Populares da Democracia: Brasil, anos 80. Petrópolis: Vozes, 1982. p.99-120.

TASSARA, E.T. (Org.). Panoramas interdisciplinares para uma psicologia ambiental do urbano. São Paulo: EDUC/FAPESP, 2001.

TEIXEIRA, E.C. Sociedade civil e participação cidadã no poder local. 1998. 342p. Dissertação (Mestrado) - Faculdade de Filosofia, Letras e Ciências Humanas, Universidade de São Paulo, São Paulo, 1998.

TELLES, V.S. Anos 70: experiências, práticas e espaços políticos. In: KOWARICK, L. (org.). As lutas sociais e a cidade, São Paulo: passado e presente. São Paulo: Paz e Terra, 1988. p.247-285.

THOMPSON, E.P. Costumes em comum. São Paulo: Cia das letras, 1998.

VARGAS, M. História da construção hidroelétrica no Brasil. Engenharia: revista do Instituto de Engenharia, São Paulo, n.505, p.24-39, dez. 1994.

VIANNA, A.; LEROY, J.P.; TAVARES R. Lutas de resistência ou lutas por um novo modelo de sociedade? Proposta, Rio de Janeiro, n.46. 1990.

VICENTINI, Y.; RIZEK, C.S. Relação público - privado e cidade empresarial. Apresentado no Seminário de História Urbana, João Pessoa, 1990.

WALDMAN, M. Ecologia e lutas sociais no Brasil. São Paulo: Contexto, 2000.

YÁZIGI, E. A alma do lugar: turismo, planejamento e cotidiano em litorais e montanhas. São Paulo: Contexto, 2001. 